\title{
Vroegtijdig optreden van omstanders ter voorkoming van oorlogen en schendingen van de rechten van de mens
}

Citation for published version (APA):

Grünfeld, F. (2003). Vroegtijdig optreden van omstanders ter voorkoming van oorlogen en schendingen van de rechten van de mens. Universiteit Utrecht. https://doi.org/10.26481/spe.20031210fg

Document status and date:

Published: 10/12/2003

DOI:

$10.26481 /$ spe.20031210fg

Document Version:

Publisher's PDF, also known as Version of record

Please check the document version of this publication:

- A submitted manuscript is the version of the article upon submission and before peer-review. There can be important differences between the submitted version and the official published version of record.

People interested in the research are advised to contact the author for the final version of the publication, or visit the DOI to the publisher's website.

- The final author version and the galley proof are versions of the publication after peer review.

- The final published version features the final layout of the paper including the volume, issue and page numbers.

Link to publication

\footnotetext{
General rights rights.

- You may freely distribute the URL identifying the publication in the public portal. please follow below link for the End User Agreement:

www.umlib.nl/taverne-license

Take down policy

If you believe that this document breaches copyright please contact us at:

repository@maastrichtuniversity.nl

providing details and we will investigate your claim.
}

Copyright and moral rights for the publications made accessible in the public portal are retained by the authors and/or other copyright owners and it is a condition of accessing publications that users recognise and abide by the legal requirements associated with these

- Users may download and print one copy of any publication from the public portal for the purpose of private study or research.

- You may not further distribute the material or use it for any profit-making activity or commercial gain

If the publication is distributed under the terms of Article $25 \mathrm{fa}$ of the Dutch Copyright Act, indicated by the "Taverne" license above, 


\title{
VROEGTIJDIG OPTREDEN VAN OMSTANDERS TER VOORKOMING VAN OORLOGEN EN SCHENDINGEN VAN DE RECHTEN VAN DE MENS
}

\author{
Rede
}

uitgesproken bij de aanvaarding van het ambt van bijzonder hoogleraar op het vakgebied van Oorzaken van Mensenrechtenschendingen aan de Universiteit Utrecht op woensdag 10 december 2003

door

Dr. Frederik Grünfeld 


\title{
VROEGTIJDIG OPTREDEN VAN OMSTANDERS TER VOORKOMING VAN OORLOGEN EN SCHENDINGEN VAN DE RECHTEN VAN DE MENS
}

\author{
MIJNHEER DE RECTOR \\ DAMES EN HEREN
}

Het is vandaag 10 december, de dag van de rechten van de mens. Vijf en vijftig jaar geleden aanvaardde de Algemene Vergadering van de Verenigde Naties resolutie 217 in Parijs. Deze resolutie is beter bekend als de Universele Verklaring van de Rechten van de Mens. Deze universele verklaring was en is de basis van het hele mensenrechtenbouwwerk waaruit vele verdragen en toezichtmechanismen zijn voortgekomen. De noodzaak daartoe als antwoord op de verschrikkingen in de Tweede Wereldoorlog is evident. Toch waren de beginselen van deze verklaring in 1948 zelfs binnen het voorbereidend comité niet onomstreden. Naast de leidende rol van mevrouw Roosevelt, die eveneens 55 jaar geleden van deze Universiteit Utrecht vanuit de Faculteit der Rechtsgeleerdheid een eredoctoraat ontving $^{1}$, zaten in dat voorbereidend comité vanuit Nederland pater Beaufort en Marga Klompé met als plaatsvervangster Hilda Verwey-Jonker. Mevrouw Verwey-Jonker, hier vanmiddag aanwezig maakte toen mee dat de voorzitter een bijeenkomst opende met de mededeling dat hij niet aan vrouwen het woord zou geven want "une femme, qui prend la parole en public ce n'est pour moi qu'une femme publique". Daarop vroeg de gedelegeerde van de Verenigde Staten, mevrouw Roosevelt het woord, de voorzitter aarzelde en ik citeer Hilda Verwey-Jonker vanuit haar autobiografie "Er moet een vrouw in": "toen begonnen er allerlei mannetjes naar de voorzitter te hollen en op hem in te praten". Hij gaf haar uiteindelijk het woord en zij hield haar reeds voorbereide betoog. ${ }^{2}$

In de eerste overweging van deze universele verklaring staat "dat erkenning van de inherente waardigheid en van de gelijke en onvervreemdbare rechten van alle leden van de mensengemeenschap grondslag is voor de vrijheid, gerechtigheid en vrede in de wereld".

\footnotetext{
${ }^{1}$ De uitreiking vond plaats op 20 april 1948.

${ }^{2}$ Hilda Verwey-Jonker: Er moet een vrouw in; Herinneringen in een kentering van de tijd, De Arbeiderspers, Amsterdam, 1988, p. 210. Interview op 5 februari 2003 te Utrecht.
} 
Deze relatie tussen de bevordering van de rechten van de mens en de bevordering van vrede in de wereld is ook terug te vinden in de preambule van het Handvest van de Verenigde Naties en in artikel 55 van dat Handvest staat dat stabiliteit en welzijn nodig zijn voor vreedzame betrekkingen en met het oog daarop de VN onder meer universele eerbiediging en inachtneming van de rechten van de mens zullen bevorderen. In de kantlijn bij de wettenbundel staat dat vermeld als "nevendoeleinden". ${ }^{3}$ Ik beschouw de bevordering van de rechten van de mens en de bevordering van vrede en veiligheid in de wereld als even belangrijke doeleinden die bovendien onlosmakelijk met elkaar verbonden zijn. Oorlogen veroorzaken altijd grootschalige en flagrante schendingen van de rechten van de mens terwijl schendingen van de rechten van de mens als de voorbode van gewelddadige conflicten in de wereld zijn te beschouwen. Dit uitgangspunt vormt de hoeksteen voor mijn betoog dat ik nader zal uitwerken.

De preventie, het voorkomen van conflicten en schendingen van de rechten van de mens staat hier dan ook centraal. Deze preventie wordt ruim opgevat zodat deze zowel het uitbreken en ontstaan omvat als de escalatie van conflicten en de toename naar ernst, omvang en frequentie van de mensenrechtenschendingen. Als deze al niet kunnen worden voorkomen kunnen ze dan niet tenminste worden ingedamd.

De drie actoren, bij oorlogen en mensenrechtenschendingen zijn de daders, de slachtoffers en de omstanders.

Mijn stelling is dat de rol van de omstander cruciaal is. Als de omstander geen actie onderneemt staat deze toe dat de dader voortgaat. Maar als de omstander wel in actie komt ten gunste van het slachtoffer kan dat er toe bijdragen dat aan de wreedheden door de dader een einde komt. Kortom in mijn visie is juist de omstander het beste in staat grootschalige schendingen van de rechten van de mens in de toekomst te voorkomen of aan de voortzetting van deze schendingen een halt toe te roepen.

\footnotetext{
${ }^{3}$ Kluwer College Bundel 2003-2004, Wetteksten II, Kluwer, Deventer 2003, p. 3629.
} 


\section{GEWELDDADIGE CONFLICTEN EN SCHENDINGEN VAN DE RECHTEN VAN DE MENS}

De centrale vraag in de leer der internationale betrekkingen is de vraag naar het ontstaan van oorlogen. De oorzaken kunnen vanuit verschillend analyse niveau worden verklaard. ${ }^{4}$ Behalve dat de oorzaken op verschillend niveau kunnen worden onderzocht kan ook naar de aanleiding tot een bepaalde oorlog worden gekeken, dat zijn dan gebeurtenissen die aan het uitbreken van oorlog voorafgaan. De gedachte is dat als de oorzaak niet of moeilijk kan worden weggenomen dan is het misschien mogelijk ter voorkoming van het uitbreken van oorlogen de aanleiding aan te pakken. Bij dit laatste tracht men een meer specifieke oorlog te voorkomen en niet oorlog in het algemeen uit te bannen. Men legt zich enigszins neer bij de onvolkomenheden zoals het ontbreken van een internationaal centraal gezag. De gebeurtenissen die de aanleiding tot een oorlog vormen zouden aldus een voorspellende waarde kunnen hebben in die zin dat wanneer zich die gebeurtenissen voordoen dat dan de kans op het ontstaan van oorlog groter wordt. Dergelijke gebeurtenissen kunnen worden gecatalogiseerd en gerubriceerd in indicatoren. Een indicator dat de kans op oorlog toenam was in het verleden, met sterkere militaire bondgenootschappen dan vandaag de dag, dat de hechtheid binnen blokken toenam en de contacten met het andere blok afnamen.

\footnotetext{
${ }^{4}$ Bijvoorbeeld vanuit subnationaal niveau is de individuele leider de oorzaak en met het ten val brengen van Saddam Hussein wordt deze oorzaak weggenomen. Vanuit nationaal niveau wordt niet zozeer de individuele leider maar de structuur van de (dictatoriale) staat als de oorzaak gezien. Met de omverwerping van bijvoorbeeld schurkenstaten, als bijvoorbeeld Irak, en deze omvormen tot democratisch bestuurde staten wordt deze oorzaak tot oorlog weggenomen. Vanuit het internationale niveau kan de oorzaak worden gezocht in de anarchie waar met het ontbreken van een internationaal centraal gezag het staten niet wordt belet oorlog te gaan voeren wanneer in hun opvatting hun nationaal belang in gevaar komt. De keuze voor het analyseniveau hangt ook samen met de visie zo wordt in de realistische stroming met name het internationale analyse-niveau genomen en wordt in de zogenoemde idealistische stroming met name het nationale niveau betrokken. Condoleezza Rice heeft het Amerikaanse optreden inzake Irak als een mengeling van deze idealistische en realistische opvattingen beschouwd. Zie Condoleezza Rice en de noodzaak tot pre-emptive strike: Condoleezza Rice discusses President's National Security Strategy, October 2002, http//www.whitehouse.gov/news/releases/2002/10/20021001-6.html.
} 
Eerder heb ik gesteld dat in toenemende mate mensenrechtenschendingen de voorbode tot oorlog vormen en het is daarom ook begrijpelijk dat de indicatoren voor mensenrechtenschendingen en de kans op oorlog steeds meer gelijkenis zijn gaan vertonen. Bovendien zijn oorlogen vaker intra-statelijke oorlogen geworden. Intra-statelijke oorlogen zijn oorlogen binnen een staat, die ook wel burgeroorlogen worden genoemd. Oorlogen tussen twee of meerdere staten, de interstatelijke conflicten zoals in het Midden-Oosten rond de Arabische Golf en het Israëlisch-Arabisch conflict zijn steeds meer uitzondering geworden. Zie onderstaande figuur: ${ }^{5}$

Gewapende conflicten 1946-2000

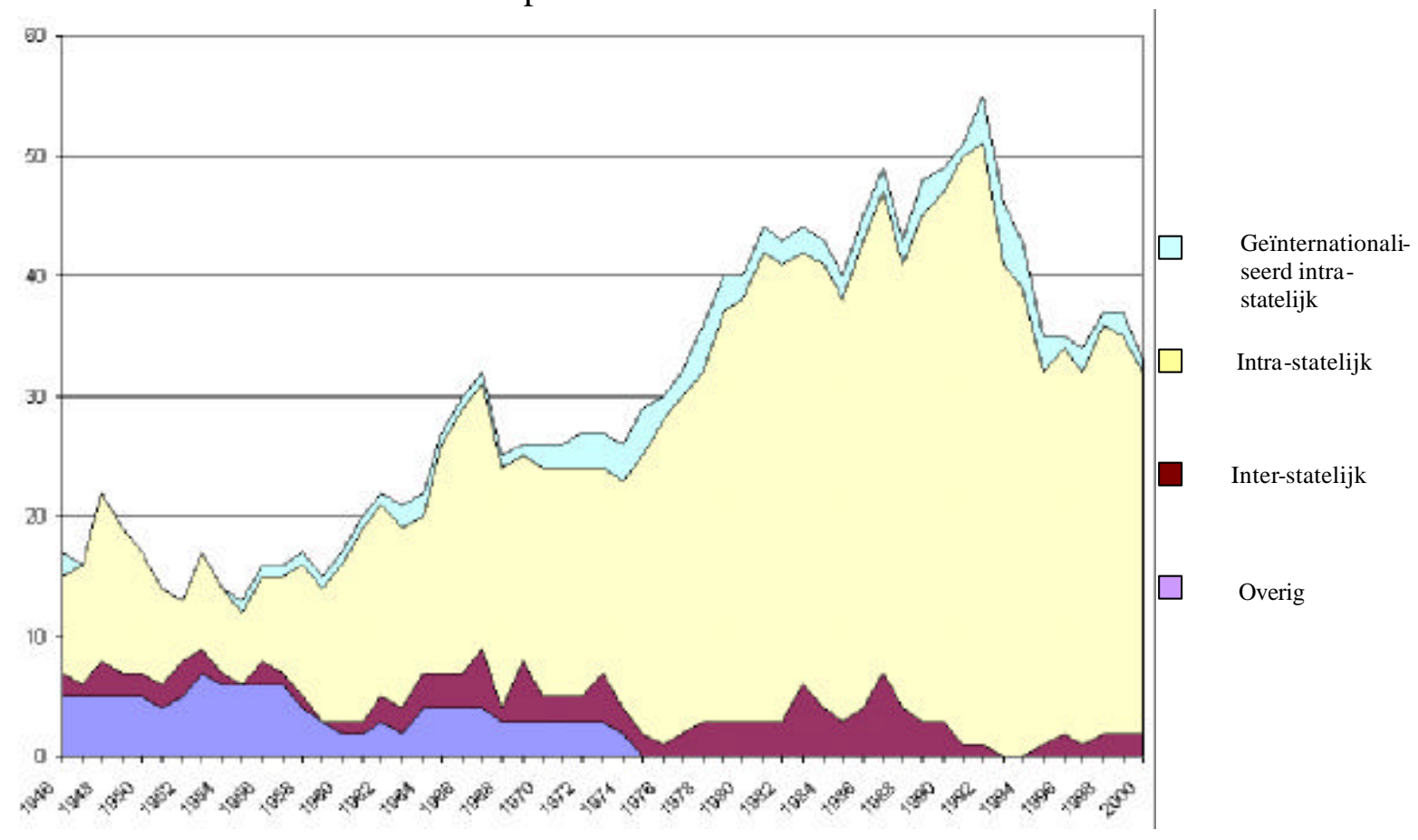

\footnotetext{
${ }^{5}$ N.P. Gleditsch, P. Wallensteen, M. Eriksson, M. Sollenberg \& H. Strand, Armed Conflict 1946-2000: A
} New Dataset; in: Journal of Peace Research, vol. 39, no 5, 2002, pp. 615-637. 
In deze verzameling van 220 conflicten zitten 157 intra-statelijke conflicten waarvan 25 geinternationaliseerd intra-statelijk zijn omdat andere staten aan de strijd deelnemen. De rubriek overig omvat 21 intra-statelijke conflicten op een ander grondgebied. Resteren slechts 42 interstatelijke conflicten in de periode 1946-2000. Zelfs bij wat nog een tamelijk klassieke interstatelijke oorlog kan worden genoemd zoals de eerste Golfoorlog en de tweede Golfoorlog overtreft het aantal burgerslachtoffers verre het aantal gedode soldaten. Burgers, de non-combattanten ondanks de vele regelgeving op dit terrein van het oorlogsrecht, zijn in toenemende mate het dodelijke slachtoffer geworden. Met de moderne oorlogsvoering kon de coalitie vanuit de lucht de tegenstander trachten uit te putten waardoor bij deze bombardementen vele burgerslachtoffers vielen. Met het zo beperkt mogelijk houden van slachtoffers onder Amerikaanse en Britse soldaten neemt zo het aantal burgerslachtoffers toe. Het wellicht meest fundamentele mensenrecht, namelijk het recht op leven, wordt in oorlogen geschonden. Oorlogen leiden ook tot andere grootschalige mensenrechtenschendingen die bijvoorbeeld direct te relateren zijn aan de stroom ontheemden en vluchtelingen die door oorlogen zijn veroorzaakt. Daarnaast kunnen geringere schendingen van de rechten van de mens onder invloed van het oorlogsgeweld ernstigere schendingen worden. Wanneer we de Israëlische maatregelen tegen de Palestijnen op het terrein van huisvesting in ogenschouw nemen dan constateren we dat weliswaar voor de Intifadah enige schending plaatsvond in de zin van het weigeren bouwvergunningen aan Palestijnen rond Jeruzalem te verlenen maar dat als gevolg van strafmaatregelen tijdens de Intifadah Palestijnen uit hun huizen werden gezet en in een tamelijk groot aantal gevallen de huizen doelbewust zijn vernietigd. ${ }^{6}$ Kortom de schending van dit sociaal-economisch mensenrecht is als gevolg van het militaire conflict ernstiger geworden.

\footnotetext{
${ }^{6}$ Zie tabel 11 op CD-ROM over Israël, bezette gebieden en Palestijnse Autoriteit.
} 


\section{Schema over de relatie tussen schendingen van de rechten van de mens en oorlogen}

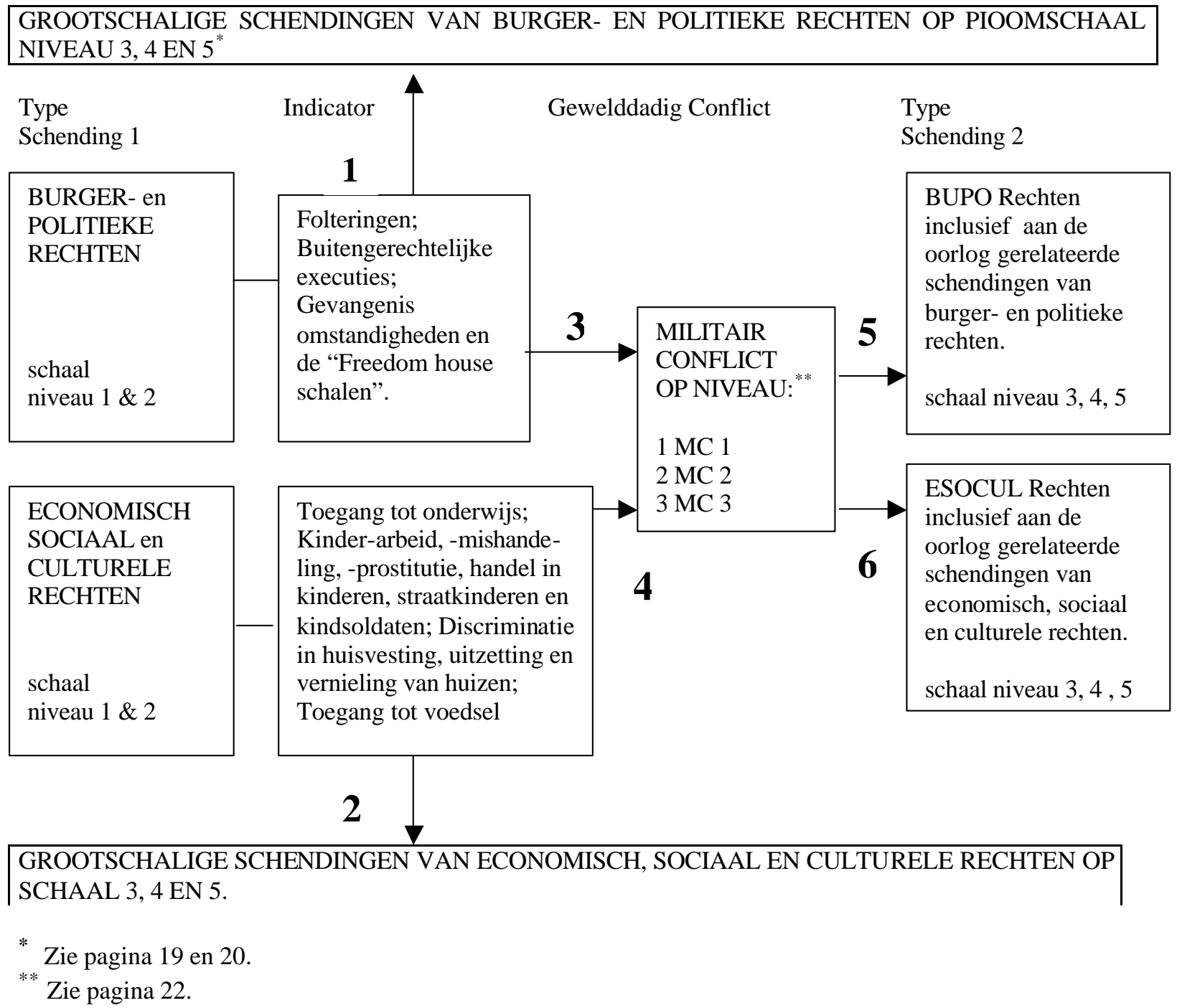


Schendingen van de rechten van de mens zijn niet alleen een gevolg van oorlogen maar vaak ook de oorzaak van oorlogen. Evenals bij de vraag naar de oorzaken van oorlog kunnen we bij schendingen van de rechten van de mens gaan zoeken naar de structurele oorzaken op het sub-nationale, het nationale en het internationale analyseniveau. Bijvoorbeeld de mens is slecht en in beginsel een racist en dat verklaart zijn handelen. ${ }^{7}$ Het gedrag van de dader tijdens de $\mathrm{Shoa}^{8}$ kan dan verklaard worden vanuit diens antisemitische gezindheid. Anderen wijzen op het normale in het karakter van de dader en zoeken de verklaring vanuit nationaal niveau in de verhoudingen in een samenleving met een ver doorgevoerde bureaucratie. ${ }^{9}$ Vanuit het internationale niveau geredeneerd, leidt de anarchie van de statensamenleving tot niet inmenging van derden en geldt de regel van de overleving van de sterkste. Immers de naleving van de rechten van de mens wordt niet opgelegd vanuit internationaal niveau. Hier valt gelukkig inmiddels wel wat op af te dingen. Niet alleen worden schendingen op een aantal terreinen in de gaten gehouden (monitoren en rapporteren) maar zien we voor de ordehandhaving ook op internationaal terrein in toenemende mate activiteiten van peace-keepers en politiewaarnemers en zijn de eerste rechters op het toneel verschenen voor de rechtshandhaving in de internationale orde. De nauwe relatie tussen enerzijds de handhaving van vrede en veiligheid en anderzijds de bescherming van de rechten van de mens in het optreden door de

\footnotetext{
${ }^{7}$ Zie Goldhagen die er van uit gaat dat Duitse militairen en politiebataljons vanuit antisemitische motieven in staat waren de standrechtelijke executies in Oost Europa uit te voeren. Daniel Goldhagen: Hitler's Willing Executioners: Ordinary Germans and the Holocaust, Boston, 1996.

${ }^{8}$ Wellicht even terzijde opgemerkt dat ik liever het woord Shoa gebruik dan Holocaust. Holocaust betekent brandoffer aan God en ik zie geen enkel verband tussen brandoffer en de verdelging der Joden. Shoa betekent in het Hebreeuws vernietiging/ondergang en dat vind ik meer van toepassing op de slachtoffers en overlevenden. Naomi Kramer, Ronald Headland, The Fallacy of Race and the Shoah, University of Ottawa Press, 1998, pp. 326 en 333 in dit bijzonder knap en educatief samengesteld boek. De termen 'verdelging' en 'ondergang' staan in de titel van het standaardwerk van J. Presser: Ondergang; de vervolging en verdelging van het Nederlandse Jodendom, 's-Gravenhage, 1965.

9 Tony Kushner, 'Pissing in the Wind'? The Search for Nuance in the Study of Holocaust 'Bystanders' in: David Cesarani, Paul A. Levine (eds.) 'Bystanders' to the Holocaust: A Re-evaluation, London, 2002, waarin hij het bekende boek van Goldhagen met Duitse 'willing executioners' stelt tegenover het minder bekende werk van Browning met de 'ordinary men', p. 59 Christofer Browning, Ordinary Men: Reserve Police Battalion 101 and the Final Solution in Poland, New York, 1992.
} 
Veiligheidsraad van de VN onder Hoofdstuk VII is meer zichtbaar geworden vanaf 1991 met de bescherming van de Koerden in Noord-Irak ${ }^{10}$ en ook wel met de instelling van de Tribunalen voor Joegoslavië en Rwanda. Wel dient daarbij bedacht te worden dat bindende beslissingen alleen onder Hoofdstuk VII, dat gaat over de handhaving van vrede en veiligheid, genomen kunnen worden en dat deze rechters pas achteraf kunnen optreden. ${ }^{11}$ Het laatste decennium is op dit terrein een enorme sprong voorwaarts gemaakt.

Hoe belangrijk de berechting en vooral de waarheidsvinding ook is, voor de gehele samenleving en voor de slachtoffers - die zich na deze waarheidsvinding met al dan niet berechting van de daders ook niet langer nog louter slachtoffers maar eerder als overlevenden zullen gaan voelen ${ }^{12}-$ de verschrikkingen die zij kunnen berechten hebben al plaatsgevonden. Misschien gaat er enige preventieve werking vanuit en zullen de daders op mogelijke berechting anticiperen. In 1939 stelde Hitler in een toespraak voor leger commandanten in Obersalzburg de retorische vraag "Wie maakt zich vandaag de dag nog druk over de vernietiging van de Armeniërs?" ${ }^{13}$ en ging voort me het opzetten van de volgende genocide. Evenals bij oorlogen kunnen we ook bij schendingen van de rechten van de mens ook de aanleidingen gaan bestuderen, kortom zijn er aanwijzingen voor

\footnotetext{
${ }^{10}$ Zie onder meer de bijdragen van Nico Schrijver, Sovereignty versus Human Rights? A Tale of UN Security Council Resolution 688 (19991) on the Protection of the Kurdish People (pp. 347-357) en Fred Grünfeld, Human Rights Violations: A Threat to International Peace and Security (pp. 427-441) in: Monique Castermans-Holleman, Fried van Hoof \& Jacqueline Smith (eds.), The Role of the Nation-State in the 21st Century; Human Rights, International Organisations and Foreign Policy - Essays in Honour of Peter Baehr, The Hague/Boston/London, 1998.

${ }^{11}$ Zie de oratie van Geert Jan Knoops, International and Internationalized Criminal Courts: the new face of international peace and security?, op 13 november 2003 aan de Universiteit Utrecht. Resolutie 827 over de oprichting van het Joegoslavië Tribunaal dateert van 25 mei 1993.

${ }^{12}$ Zie ook Theo van Boven, Cees Flinterman, Fred Grünfeld en Ingrid Westendorp (eds.) The Right to Restitution, Compensation and Rehabilitation, SIM Special no. 12, Utrecht/Maastricht, 1992.

${ }^{13}$ Stanley Cohen, State Crimes of Previous Regimes: Knowledge, Accountability, and the Policing of the Past, Law and Social Inquiry, 1995, p. 20. Raya Cohen, The Lost Honour of Bystanders? The Case of Jewish Emissaries in Switzerland in: David Cesarani, Paul A. Levine (eds.) 'Bystanders' to the Holocaust: A Reevaluation, London, 2002, p. 154 en dat is gebaseerd op V. Dadrian, Histoire du Genocide Arménien, Paris, 1966.
} 
grootschalige mensenrechtenschendingen te vinden. Bepaalde gebeurtenissen of ontwikkelingen kunnen daar aan vooraf gaan. Wanneer deze kunnen worden getraceerd, zou erger kunnen worden voorkomen. Inderdaad wederom de gelijkenis met oorlogen, wellicht kunnen ook schendingen van de rechten van de mens niet worden uitgebannen maar kunnen bepaalde schendingen worden voorkomen of enigszins binnen de perken worden gehouden. Met dat laatste bedoel ik dat de ernst en de schaal van deze schendingen beperkt blijft, bij voorkeur afneemt en ieder geval niet escaleert. Daar is mijn onderzoek op gericht.

Zoek deze indicatoren en breng die in kaart en maak deze bekend als zijnde een betrouwbare vroegtijdige waarschuwing met het oog op vroegtijdig optreden ter voorkoming van een ernstige situatie. Dat vroegtijdig optreden is dan vooral een taak voor de derde actor, de omstander.

\section{VROEGTIJDIGE WAARSCHUWING EN VROEGTIJDIG OPTREDEN}

Vroegtijdig optreden is mogelijk na de ontvangst van een vroegtijdige waarschuwing. Net als de ontwikkelde waarschuwingen voor natuurrampen als orkanen, aardbevingen en vulkaanuitbarstingen, zouden ook aanwijzingen ontwikkeld kunnen worden voor de niet door de natuur maar door de mens veroorzaakte rampen als gewelddadige conflicten en grove mensenrechtenschendingen. ${ }^{14}$ Het vinden van betrouwbare aanwijzingen, die we indicatoren noemen, is een belangrijke taak in mijn onderzoek. Preventie vereist vroegtijdige actie, terwijl vroegtijdige actie pas mogelijk is na de ontvangst van vroegtijdige waarschuwing. De vroegtijdige waarschuwingen zijn dus wezenlijk en kunnen gezien worden als een noodzakelijke voorwaarde. Let wel, het voorspellen van welke gebeurtenis op welk moment zal plaatsvinden is niet mogelijk maar het doel is over de

\footnotetext{
${ }^{14}$ Zie bijvoorbeeld ook de definitie van het West Africa Network for Peacebuilding, Accra-Ghana, 2000, p. 11: "Early warning is the collection and analysis of information about potential and/or actual conflict situations, and the provision of policy options to influential actors at the national, regional and international levels that may promote sustainable peace"; zie ook http://www.fewer.org/resources/methodology_38.html.
} 
waarschijnlijkheid van het uitbreken van mensenrechtenschendingen een oordeel te geven. De vraag is dan welke indicatoren kunnen die aanwijzing geven en zijn die indicatoren voor militaire conflicten en mensenrechtenschendingen gelijk, verschillend of aan elkaar gerelateerd. Dat ga ik onderzoeken. Ik zal niet verhelen dat anderen deze benadering afwijzen op grond van de volgende argumenten. Vele conflicten en mensenrechtenschendingen zijn volstrekt verschillend, niet alleen door de specifieke context maar ook door het grote verschil in type schendingen. Elke generalisatie - zo wordt wel beweerd - is onmogelijk en het begin van zelfs maar enige voorspelling op dit terrein is tot mislukking gedoemd want menselijk gedrag is onvoorspelbaar. ${ }^{15}$ Bovendien leidt early warning tot het averechtse effect want het zal investeringen in dat land afschrikken ${ }^{16}$ of als zichzelf vervullende voorspelling werken want de waarschuwing lokt juist het conflict uit. ${ }^{17}$ Dit laatste is in het licht van de oorlog in Irak van het afgelopen voorjaar interessant. Er lijkt sprake te zijn geweest van het zogenoemde "aandikken" van de informatie om voor een vroegtijdige actie publieke en politieke steun te verwerven. In de toespraak van de Britse premier Blair op 24 september 2002 voor het Britse parlement stelde hij dat de Iraakse militairen in staat zijn binnen 45 minuten na een beslissing massavernietigingswapens in te zetten. De 45 minuten frase stond niet in het oorspronkelijke dossier maar werd op verzoek van Blair toegevoegd. ${ }^{18}$ De prijs van een dergelijke overdrijving is niet alleen de kritiek van parlementaire zijde maar ook dat het een volgende keer nog moeilijker zal worden de politiek en de publieke opinie te overtuigen voor vroegtijdig optreden. Dat leidt tot

${ }_{16}^{15}$ Ibidem, p. 10 de zogenoemde desillusie stelling.

${ }^{16}$ Ibidem, p. 10 de zogenoemde afleiding (diversion) stelling.

${ }^{17}$ Ibidem, p. 10 de zogenoemde perversie stelling: "warning may spark pre-emptive actions, particularly from state actors against the agitators predicted. In short, warning intended to forestall a conflict is often likely to exacerbate it by defining it, altering the balance of power, or delaying necessary adjustments".

${ }^{18}$ Tony Blair zei toen in het House of Commons: "His weapons of mass destruction program is active, detailed and growing. The Iraqi military are able to deploy these weapons within 45 minutes of a decision to do so." Na de oorlog die plaatsvond van 20 maart 2003 tot 14 april 2003, stelde de BBC televisie op 29 mei op grond van informatie - naar later bleek - van de wapendeskundige Kelly: "It [the dossier] was transformed in the week before it was published to make it sexier. The classic example was the claim that weapons of mass destruction were ready for use within 45 minutes. That information was not in the original draft. It was included in the dossier against our wishes, because it wasn't reliable ... [it] was transformed at the behest of Downing Street." Time, September 8, 2003, The war of the words, pp. 26-27. 
afkalving van vroegtijdig optreden en humanitaire interventie en de versterking van degene die de soevereiniteitsgedachte beklemtonen.

Drie type aanwijzingen zijn ontwikkeld: ${ }^{19}$

1. de structurele oorzaken - betrekking hebbend op de lange termijn - waarin over het algemeen niet op korte termijn verandering kan worden bewerkstelligd. dat zijn voorwaarden en structurele factoren die conflicten voeden want hun aanwezigheid in een samenleving verhoogt de kans op een gewelddadig conflict Te denken valt aan de achterliggende oorzaken zoals aan armoede, bewapening, analfabetisme etcetera. $^{20}$

2. de aanleiding die pas zichtbaar wordt vlak voor het uitbreken van het conflict, zoals de schoten in Sarajevo op 28 juni 1914 op de Oostenrijkse troonopvolger Frans Ferdinand die de eerste Wereld Oorlog ontketenden of het neerschieten van een vliegtuig met aan boord de Rwandese president Habyarimana op 6 april 1994 dat de directe aanleiding voor de genocide in Rwanda vormde. De aanleiding zelf is niet te voorspellen want de gebeurtenis komt onverwachts. ${ }^{21}$

3. de korte termijn (operationele) oorzaken, daarbij valt te denken aan een verandering in de bevolkingssamenstelling, de toevoer van wapens Het zijn in het bijzonder de korte termijn oorzaken die de kans op het uitbreken van conflicten en mensenrechtenschending het meest bepalen. ${ }^{22}$ Deze operationele oorzaken, heb ik

${ }^{19}$ FEWER, Forum on Early Warning and Early Response: Conflict Analysis and Response Definition, Abridged Methodology, April 2001 en: Susan Ampleford, Methodology Review, Discussion Paper Country Indicators for Foreign Policy, July 2000; en: WANEP Preventive Peacebuilding in West Africa, October 2000, www.fewer.org.

${ }^{20}$ ibidem, Structural Causes of Root Causes genoemd.

${ }^{21}$ ibidem, Triggers genoemd.

${ }^{22}$ ibidem, Proximity Causes of Accelerators genoemd. In de vergelijking van Waltz ten aanzien van de oorzaken van oorlog zijn de structurele oorzaken eerder te vergelijking met de permissive causes en de korte termijn oorzaken eerder te zien als de directe oorzaken vergelijkbaar met de staatsstructuur van het oorlogsgeneigde land. Kenneth Waltz: Man, the State and War uit 1954 en Theory of International Relations uit 1979; zie ook de uitleg van deze benadering door Cynthia Weber, International Relations Theory, A Critical Introduction, Routledge, London, New York, 2001, pp. 14-22. 
op het oog en daarvoor wil ik de indicatoren ontwikkelen. Niet de hoogte van het analfabetisme - als de structurele oorzaak - maar de discriminerende maatregelen die de toegang tot het onderwijs verhinderen - als de operationele oorzaak - staan dan voorop. Het gaat over mensenrechtenschendingen die de staat te verwijten te zijn, waar de betreffende staat voor verantwoordelijk kan worden gehouden en die als een schendingen kunnen worden vastgesteld.

De aanwijzingen voor gewelddadige conflicten en de aanwijzingen voor mensenrechtenschendingen kunnen gelijk zijn. Bijvoorbeeld een wijzigende bevolkingssamenstelling kan tot spanningen en discriminatie leiden. De demografische factoren zouden de structurele lange termijn oorzaken kunnen worden genoemd. Een plotselinge vluchtelingenstroom die demografische verhoudingen verandert, is dan de korte termijn oorzaak. De mensenrechtenschending is dan veelal discriminatie, terwijl discriminatie zowel burger- en politieke rechten als sociaal-economische rechten schendt. Een door mij gebruikte indicator daarvoor is de belemmerde toegang tot het onderwijs en de woningmarkt. In de situatie van Macedonië werden deze signalen door de internationale gemeenschap en met name de OVSE in de persoon van Van der Stoel vroegtijdig ${ }^{23}$ opgepikt. Bijvoorbeeld zijn optreden als de hoge commissaris voor de minderheden in Macedonië is illustratief. In 1997 nam de Albanese minderheid met $10 \%$ toe, terwijl deze gevoelige demografische verandering tussen de Slavische Macedoniërs en de etnische Albanezen in Macedonië niet tot een gewelddadig conflict leidde. Inzake de taalkwestie lukte het Van der Stoel niet zodanig te bemiddelen dat de Albanese minderheid tot de universiteit werd toegelaten. Vervolgens heeft hij in Europa geld geworven en is overgegaan tot de stichting van een particuliere universiteit waar deze Albanese minderheid wel werd toegelaten. Daarmee werd een mogelijke oorzaak voor het uitbreken

\footnotetext{
${ }^{23}$ Wanneer de vroegtijdige waarschuwing ook door de direct betrokkenen ter harte wordt genomen zou een vroegtijdig optreden zelfs achterwege kunnen blijven en wanneer met optreden de conflicthaard wordt weggenomen zou geen waarschuwing meer nodig zijn. Max van der Stoel:'My job is to issue early warnings to avoid action, and to take action to avoid early warnings' uit Quentin Peel, 'OSCE Minorities chief aims for early action', Financial Times (19 mei 2000) in: W.A. Kemp (ed.), Quiet Diplomacy in Action: The HCNM, Kluwer Law International, Ashgate 2000, p. 34. Deze optimistische kijk gaat vaak niet op en is wel degelijk een handelen nodig op grond van de waarschuwing.
} 
van een gewelddadig conflict aangepakt. De Albanezen voelden zich namelijk in Macedonië als tweederangs burgers behandeld met onvoldoende mogelijkheden tot ontplooiing. ${ }^{24}$ De Grondwet voorzag niet in de stichting van een Albaneestalige universiteit. Van der Stoel vroeg aan de Macedonische regering begrip voor deze gevoelige onderwijs/taalkwestie. ${ }^{25}$ De controverse stond centraal en van der Stoel ging op zoek naar een alternatief in het oprichten van een particuliere universiteit door een internationale stichting met een aantal Europese onderwijsdeskundigen in het bestuur. ${ }^{26}$ Dat is gelukt want met de financiering door een aantal EU lidstaten, de Europese commissie en de Verenigde Staten kon in 2002 de South-Eastern University starten. ${ }^{27}$

Aan dit optreden lag ten grondslag dat de signalen van discriminatie en door een wijzigende bevolkingssamenstelling de kans op een gewelddadig conflict aannemelijk maakte zodat optreden geboden was. ${ }^{28}$ Kortom vroegtijdige waarschuwing en vroegtijdig optreden lagen in elkaars verlengde.

\footnotetext{
${ }^{24}$ M. van der Stoel, Conflictpreventie - de lessen van Kosovo en Macedonië, oratie, universiteit van Tilburg, 25 januari 2002, p. 22.

${ }^{25}$ M. van der Stoel, Conflictpreventie - de lessen van Kosovo en Macedonië, oratie, universiteit van Tilburg, 25 januari 2002, p. 23.

${ }^{26}$ M. van der Stoel, Conflictpreventie - de lessen van Kosovo en Macedonië, oratie, universiteit van Tilburg, 25 januari 2002, p. 24.

${ }^{27}$ OVSE Jaarrapport 2002.

${ }^{28}$ Bijvoorbeeld een heuvel werd door Macedonië geclaimd in juni 1994 waarop prompt Servische militairen de heuveltop gingen bezetten. De VN vredesmacht die daar gesitueerd was nam dit waar en reageerde door de heuveltop onder de VN controle te plaatsen en te bepalen dat daar de bufferzone liep. Zonder ernstig gezichtverlies werd dit vroegtijdig opgelost. Uit: A.Williams, Preventing War, The United Nations and Macedonia, Rowman \& Littlefield, 2000, pp. 73, 93, 94.
} 


\section{OORZAKEN EN INDICATOREN}

De informatie voor de indicatoren kan worden afgeleid uit oorzaken van conflicten en mensenrechtenschendingen. Zoals zojuist gesteld zijn er structurele en operationele oorzaken. Ook elk optreden wordt daardoor bepaald en zo is een onderscheid gemaakt tussen preventief structureel optreden en preventief operationeel optreden. Deze lijn wil ik hier doortrekken naar indicatoren zodat het mogelijk is een onderscheid te maken naar indicatoren afgeleid uit structurele oorzaken en gericht op het optreden op de lange termijn, naast de indicatoren die worden afgeleid uit de operationele oorzaken en er dan ook op gericht zijn om als signaal te dienen voor het optreden op de korte termijn. Het doel daarbij is steeds zowel het voorkomen van het uitbreken van gewelddadige conflicten en mensenrechtenschendingen als het voorkomen van een escalatie in het aan de gang zijnde conflict of de schendingen van de rechten van de mens. Deze ruimere definitie is van Luc Reychler ${ }^{29}$ die met conflictpreventie zowel het uitbreken van conflicten als het escalatie proces en het weer oplaaien van gewelddadige conflicten op het oog heeft.

Een mensenrechten indicator geeft enige informatie over de mate waarin een recht wordt vervuld of genoten in een bepaalde situatie. ${ }^{30}$ Statistieken zijn op zichzelf nog geen indicatoren maar deze kunnen daar wel toe dienen, bijvoorbeeld het aantal dagelijkse calorieën van beschikbaar voedsel voor de schending van het recht op voedsel. Een mensenrechten indicator verwijst zowel naar de mate waarin een regering aan zijn verplichtingen voldoet als naar de mate waarin ieder individu van de gegarandeerde rechten gebruik kan maken. ${ }^{31}$ Eigenlijk zijn die benaderingen niet zo verschillend want bij een recht hoort een verplichting en bij niet nakoming daarvan hebben we te maken met een schending $^{32}$. Bovendien wordt bij de rapportage verplichtingen van staten aan Genève ${ }^{33}$

\footnotetext{
${ }^{29}$ L. Reychler, Democratic Peace-Building and Conflict Prevention: The devil is in the transition, Leuven, 1999 , p. 11 die dat pro-actieve en re-actieve conflict preventie noemt.

${ }^{30}$ Maria Green: Current Approaches to Human Rights Measurement, in Human Rights Quarterly, 23 (2001), pp. 1062-1097, p. 1065.

31 Ibidem, "government compliance en individual enjoyment", p. 1085-1088.

${ }^{32}$ Ibidem, "where there is a right there is a duty, and where the duty is not met there is a violation." p. 1086.
} 
ook naar beide facetten gevraagd. Het is evenmin het geval dat indicatoren voor burger en politieke rechten louter op overheidsverplichtingen duiden en de economische en sociale rechten alleen gericht zijn op de gebruikmaking van die rechten. ${ }^{34}$ Bij beide rechten kunnen overheidsuitgaven gemoeid zijn. De voortgaande realisatie is met name voor de sociaal-economische rechten een belangrijke maatstaf om het al dan niet bestaan van een schending te kunnen vaststellen. Dat geldt zowel voor de rijke als de arme landen en daarom is armoede in deze zin niet per definitie een schending van sociaal-economische rechten. Ik verwijs in dit verband naar de uitwerking in de "Maastricht Guidelines". ${ }^{35} \mathrm{Er}$ is in elk geval sprake van een directe schending wanneer sprake is van discriminatie bij de toekenning van ook de sociaal-economische rechten. ${ }^{36}$ Bij huisvesting of onderwijs ben ik deze schending vaak tegengekomen in mijn onderzoek, waarover dadelijk meer. ${ }^{37}$

Empirisch onderzoek naar de relatie tussen de sociaal-economische mensenrechten en de burger- en politieke rechten is nog beperkt. ${ }^{38} \mathrm{Bij}$ de opzet van onderzoeken op dit terrein worden de sociaal-economische rechten - als deze er al bij worden betrokken - soms gelijk gesteld met het bruto nationaal product en als men dan bedenkt dat de welvaartsverdeling binnen een land relevant is dan vult men daar enkele statistische gegevens als analfabetisme, levensverwachting en dergelijke voor in. Daarmee meet men nog geen schendingen maar hooguit de relatie tussen welvaartspeil en de mate van vervulling van enkele basisbehoeften. Vervolgens blijft men steken in de constatering dat er geen negatief

\footnotetext{
${ }^{33}$ De rapportage van staten aan de toezichthoudende comités van de verschillende mensenrechtenverdragen waar zij partij bij zijn; die comités zetelen grotendeels in Genève.

${ }^{34}$ Maria Green, p. 1091.

${ }^{35}$ Theo van Boven, Cees Flinterman, Ingrid Westendorp, Human Rights, Maastricht Perspectives, Maastricht Centre for Human Rights, 1999, pp. 21-30.

${ }^{36}$ Maria Green, p 1071.

${ }^{37}$ Enkele door mij gebruikte indicatoren zijn ook door Maria Green vermeld op p. 1074 zoals toegang tot voedsel, geen gedwongen huisuitzetting, toegang tot onderwijs, geen dwangarbeid en adequate arbeidsomstandigheden.

${ }^{38}$ Zie voor een goed overzicht Wesley T. Milner, Steven C. Poe en David Leblang: Security Rights, Subsistence Rights and Liberties: A Theoretical Survey of the Empirical Landscape; in: Human Rights Quarterly 21 (1999) pp. 403-443, p. 405, 411.
} 
verband bestaat tussen economische ontwikkeling en de burger- en politieke rechten. ${ }^{39}$ Bij het bepalen van de relatie tussen de beide type rechten speelt de visie op het karakter van de sociaal-economische rechten eveneens een rol. Zo stelt de één dat beide rechten los van elkaar verwezenlijkt kunnen worden omdat de politieke rechten geen beroep op beschikbare middelen doen hetgeen bij sociaal-economische rechten wel het geval zou zijn. ${ }^{40}$ Anderen zien wel een samenhang en menen daarom dat pas na verwezenlijking van basale sociaal-economische rechten de politieke rechten kunnen worden gerealiseerd. Niet om met Brecht te spreken "Erst kommt das Fressen und dann die Moral" maar omdat onderdrukking van de politieke elite pas dan minder nodig is aangezien de armoede geen mobilisatie factor meer is. Howard en Donally verzetten zich tegen een dergelijke opeenvolging waarbij de realisering van burger- en politieke rechten kan worden opgeschort. ${ }^{41}$ Ook Jan Pronk wees op het belang van de participatie in de besluitvorming voor de eerlijke verdeling van de hulpbronnen. ${ }^{42}$ Burger- en politieke rechten zijn dan zowel middelen voor de realisering van sociaal-economische rechten als doeleinden op zich zelf. Een nauwe relatie en onderlinge verbondenheid van de beide type rechten leidt dan juist niet tot opschorting van het een tot het ander is gerealiseerd maar tot een inspanning beide te realiseren. Een opeenvolging kan zowel door de donorlanden als door de doelstaten voor eigen doeleinden misbruikt worden waardoor noch de economische ontwikkeling noch de rechten van de mens worden bevorderd. In de notitie over het conflictpreventiebeleid van de Nederlandse regering wordt deze relatie onderkend door te stellen dat wanneer er geen beroep kan worden gedaan op elementaire burger- en politieke

\footnotetext{
${ }^{39}$ Ibidem, p. 412.

${ }^{40}$ Ibidem p. 417 waarin Paul Streeten, Basic Needs and Human Rights, 8 World Dev 107 (1980) wordt aangehaald.

${ }^{41}$ Ibidem p. 407, 416, 417. waarin wordt aangehaald: Jack Donnelly, Universal Human Rights in Theory and Practice (1989), p. 165, 166. Rhoda Howard, The Full-Belly Thesis: Should Economic Rights take priority over Civil and Political Rights? : Evidence from Sub-Saharan Africa, 5 Human Rights Quarterly, 1983, p. 470, 482.

${ }^{42}$ Peter Baehr, Monique Castermans-Holleman, Fred Grünfeld, Human Rights in the Foreign Policy of the Netherlands, Antwerpen/Oxford/New York, 2002, p. 18 uit: Een wereld van Verschil, p. 61, Tweede Kamer, 1990-1991, 21 813, no. 1-2.
} 
rechten daarmee de toegang tot economische en sociale rechten wordt geblokkeerd. ${ }^{43}$ In deze notitie wordt armoede als voedingsbodem voor geweld naar voren gebracht en aldus de preventie van mensenrechtenschending met de preventie van gewelddadige conflicten in verband gebracht.

\section{VOORBEELDEN}

In mijn onderzoek voor deze leerstoel en in afwachting van de officiële benoeming, heb ik reeds enkele onderzoeksresultaten kunnen presenteren in Turijn, Tel Aviv en Tilburg. Ik ben elf staten gaan bestuderen die in de periode van na de Koude Oorlog (de periode 19892002) soms in een situatie verkeerden waarin de rechten van de mens slechts in geringe mate en op kleine schaal werden geschonden ${ }^{44}$ maar op andere tijdstippen te kampen kregen met ernstige flagrante en grootschalige mensenrechten schendingen. ${ }^{45}$ De vijf PIOOM niveau's zijn:

Schaal Niveau 1: Mensen leven in een veilige rechtsstaat, er vindt geen gevangenschap op grond van opvattingen plaats, marteling is uitzonderlijk en een politieke moord is bijzonder zeldzaam.

Schaal Niveau 2: Enkelen worden gevangengezet vanwege niet-gewelddadige politieke activiteiten. Mishandeling en marteling zijn uitzonderlijk en politieke moord vindt zelden plaats.

Schaal Niveau 3: Gevangenschap vanwege politieke opvatting komt veel voor. Executies, politieke moorden en wreedheden zijn gebruikelijk. Gevangenisstraf, al dan niet na een proces, voor onbepaalde tijd vanwege politieke opvattingen is aanvaard.

Schaal Niveau 4: Veel meer mensen dan bij niveau 3 worden gevangen gezet vanwege hun politieke opvattingen. Moorden, verdwijningen en martelingen zijn gebruikelijk en alledaags. De getroffenen zijn vooral degenen met belangstelling voor politiek en andere opvattingen.

\footnotetext{
${ }^{43}$ Conflictpreventiebeleid, Tweede Kamer 2001-2002, 28 065, nr. 1.

${ }^{44}$ PIOOM schaal 2.

${ }^{45}$ PIOOM schaal 3, 4 en 5.
} 
Schaal Niveau 5: De hele bevolking is doelwit van geweld geworden. De leiders uit deze samenlevingen zullen zonder enige beperking en met gebruikmaking van alle middelen hun persoonlijke of ideologische doeleinden nastreven.

Van 11 staten heb ik de ernst (mishandeling - marteling), frequentie (sporadisch - vaak) en de reikwijdte (alleen politieke tegenstanders - gehele bevolking) van de schendingen van de rechten van de mens op burger- en politiek terrein evenals op sociaal-economisch terrein in kaart gebracht op basis van door anderen verzamelde rapporten. Het is dan ook een op rapporten gebaseerd onderzoek en niet op basis van ter plaatse zelf onderzochte gebeurtenissen. ${ }^{46}$ In Harvard wordt nu onderzoek verricht naar de gebeurtenissen in Sri Lanka, later zal ik die onderzoeksresultaten met mijn gegevens gaan vergelijken.

Kwantitatieve indicatoren verschaffen een snel overzicht over een situatie en vergemakkelijken vergelijkingen tussen staten. Kwantitatieve gegevens zijn aldus goede signalen voor vroegtijdige waarschuwingen. Wil je echter over een grondiger kennis van de situatie beschikken dan heb je kwalitatieve gegevens nodig. Deze diepgaande studies met gegevens over de mensenrechtensituatie in een bepaalde staat in een bepaald jaar worden verricht door gouvernementele en non-gouvernementele organisaties. Het is goed mogelijk deze kwalitatieve gegevens om te zetten in kwantitatieve gegevens. Zo zijn de ernst, frequentie en reikwijdte van verschillende mensenrechtenschendingen gekwantificeerd. De Purdue/Pioomschaal is zo juist gepresenteerd en het Freedom House heeft een zespuntsschaal ontworpen voor burger- en politieke mensenrechtenschendingen. ${ }^{47}$ Beide heb ik in mijn studie gebruikt. Een voorbeeld van een abrupte daling in de Freedom House schaal is te vinden in Mali dat in 1992 van een dictatuur in een democratie veranderde. Dat leidde tot een daling in de schending van de politieke rechten van 6 naar 2 en in de burgerrechten van 4 naar $3 .^{48}$ Daarnaast heb ik andere kwalitatieve

\footnotetext{
${ }^{46}$ Voor het onderscheid naar kwalitatieve en kwantitatieve waarschuwingssystemen en indicatoren zie onder meer A. Austin, Early Warning and the Field: A Cargo Cult Science? In: Berghof Handbook for Conflict Transformation, 2003.

${ }^{47} \mathrm{Zie}$ voor de uitleg over burger- en politieke rechten van Freedom House op CD-ROM.

${ }^{48}$ Zie de tabel 4 op CD-ROM over Mali.
} 
gegevens uit de jaarrapporten van het Amerikaanse Ministerie van Buitenlandse Zaken omgezet in kwantitatieve gegevens. Voor schendingen van de rechten van het kind heb ik gewerkt met kindermishandeling, kinderarbeid, gedwongen kinderarbeid, kinderprostitutie en handel in kinderen voor prostitutiedoeleinden. Ik heb - na een pilotstudie - besloten de gegevens uit de Amerikaanse jaarrapporten te verzamelen. In een vooronderzoek heb ik de gerapporteerde schendingen voor de twaalf staten over een jaar - 2000/2001 - door drie landen, te weten Noorwegen, Nederland en de Verenigde Staten, twee algemene nongouvernementele mensenrechten organisaties, Amnesty International en Human Rights Watch en enkele gespecialiseerde mensenrechtenorganisaties ${ }^{49}$ op het terrein van kindsoldaten, huisvesting, kinderrechten, kinderprostitutie en voedsel vergeleken. De resultaten van dit vooronderzoek zijn kort geleden gepubliceerd en de conclusie is dat de Amerikaanse bron goed en zeer uitgebreid is en eveneens veel aandacht schenkt aan sociaal-economische schendingen naast de burger en politieke schendingen. ${ }^{50}$ Een vertekening in hun berichtgeving op grond van hechte bilaterale relaties met een bepaald land kon niet worden geconstateerd. Een Amerikaanse vooringenomenheid was in deze periode van onderzoek afwezig. Dat laatste wordt bevestigd vanuit ander Brits-Amerikaans wetenschappelijk onderzoek. ${ }^{51}$ Kortom de toegevoegde waarde van de andere bronnen als informatieverschaffers voor de schendingen was gering en het onderzoek kon worden voortgezet met de zeer bruikbare rapporten van het Amerikaanse State Department. In het vooronderzoek concludeerden Alette Smeulers en ik dat de Verenigde Staten zijn dominante positie in de wereld ook inzake de rapportage van mensenrechtenschendingen waarmaakt.

\footnotetext{
${ }^{49}$ Respectievelijk CSUCS, COHRE, DFCI, ECPAT en FIAN.

${ }^{50}$ Fred Grünfeld en Alette Smeulers, NGO's als informatieverschaffers in vergelijking met statelijke actoren; uit: Cees Flinterman en Willem van Genugten (red.). Niet-statelijke actoren en de rechten van de mens; gevestigde waarden, nieuwe wegen; Den Haag, Boom Juridische Uitgevers, 2003, pp. 93-118.

${ }_{1}$ Steven C. Poe, Sabine C. Carey, How are these pictures different? A quantitative comparison of the US State Department and Amnesty International Human Rights Reports 1976-1995, Human Rights Quarterly 23 (2001) pp. 650-677. De rapporten van voor 1993 waren echter van veel minder kwaliteit en toonden wel de vooronderstelde vooringenomenheid.
} 
Daarnaast ben ik voor de staten de veiligheid gaan onderzoeken met gebruikmaking van een driedeling waarbij als gevolg van overheidsgeweld in een jaar tijd respectievelijk minder dan 100, tussen de 100 en 1000 en meer dan 1000 doden zijn gevallen. De driedeling voor gewelddadige conflicten is:

MC 1: gewelddadig politiek conflict met minder dan 100 doden per jaar.

MC 2: militair conflict van lage intensiteit met tussen de 100 en 1000 doden per jaar.

MC 3: militair conflict van hoge intensiteit met meer dan 1000 doden per jaar.

De informatie over aantallen was minder eenvoudig te verzamelen dan ik veronderstelde. De relatie tussen oorlogshandelingen en mensenrechtenschendingen kon vervolgens nader worden onderzocht. Beoogd is ook een opeenvolging aan te kunnen brengen in de zin van wat gaat aan wat vooraf om tot een vroegtijdige waarschuwing te komen.

Ik zal nu enkele resultaten van dit onderzoek naar elf staten dat een periode van 13 jaar (1989-2002) omvat geven. De bestudeerde staten zijn Kenia, Algerije, Tunesië, Mali, Georgië, Kroatië, El Salvador, Paraguay, Thailand, Sri Lanka met het gebied van de Tamils en Israël met de Palestijnse gebieden. De gegevens zijn vanaf vandaag beschikbaar op een cd-rom, die u na afloop bij het verlaten van deze zaal krijgt. Het wordt gedocumenteerd met 1081 bronnen. In deze oratie beperk ik mij tot slechts enkele voorbeelden.

\section{Kenia}

Binnen Kenia spelen meerdere conflicten tegelijkertijd. De algehele situatie in Kenia wordt gekenmerkt door veel geweld en erg veel onderdrukking. Deze onderdrukking is toegenomen van Pioom-schaal 2 in 1989, naar schaal 3 in 1990/1991 en vervolgens naar schaal 4 in 1992/1997 waarna de situatie iets verbeterde naar schaal 3. Deze onderdrukking op de politieke terreur schaal weergegeven, komt overeen met de ernst van de schendingen van de burger- en politieke rechten van de mens. Nagenoeg de gehele periode op het hoogste niveau van zeer ernstige schendingen. Vanaf 1989 stijgt het aantal folteringen steeds meer. Er is enige variatie in het geweldsniveau te constateren want er was meer 
geweld in 1992/1993 en 1997/2002 dan in de daaraan voorafgaande en tussenliggende perioden. Wanneer we vervolgens de verschillende schendingen bestuderen valt de continuiteit in de ernstige schendingen op en kunnen we nauwelijks verschillen als gevolg van de verheviging van geweld ontdekken buiten de voor de hand liggende toename in buitengerechtelijke executies vanaf 1996. Daarnaast sterven veel mensen in gevangenissen - ongeveer elk jaar 800 mensen - als gevolg van martelingen, ziekten, het ontbreken van medische zorg en gebrek aan voedsel. Het is echter lastig te bepalen of deze grove schending de staat is aan te rekenen. Wellicht alleen wanneer het een bewuste nalatigheid betreft maar Kenia heeft meestal te lijden gehad van de droogte met als gevolg voedsel tekort in het hele land.

\section{Algerije}

De ontwikkeling in Algerije is spectaculair te noemen. De eerste jaren bestonden de schendingen slechts uit kinderarbeid en enige gevallen van marteling. Echter vanaf 1992 vinden martelingen en buitenrechtelijke executies op grote schaal plaats. De noodtoestand geldt en een storm van geweld raast door het land gedurende het hele decennium. In 1998 en in 1999 kwamen elk jaar bijvoorbeeld ruim zeven duizend mensen om het leven, terwijl de president in 1999 toegaf dat 100.000 mensen in de voorafgaande acht jaar zijn gedood. Zowel de burgerrechten als de politieke rechten werden continu zeer ernstig geschonden vanaf 1992. De toename van militair geweld gaat hier dan ook hand in hand met een toename in de schending van de burger en politieke rechten. Lijfstraffen was een bekend fenomeen in Algerije maar als gevolg van het geweld waarbij families van het platteland naar de stad zijn gevlucht nam de bescherming af en het huiselijk geweld toe. In dit laatste geval is deze schending van de rechten van het kind een gevolg van het militair geweld. De omstandigheden in de gevangenis zijn de laatste jaren verbeterd mede als gevolg van inspecties van het Internationale Rode Kruis en andere internationale omstanders.

De verslechtering startte echter in 1991 met de schending van de BUPO rechten in het afgelasten van de verkiezingen en het verbod op de belangrijkste politieke partij het FIS. Algerije past wat dat betreft in het voor dit onderzoek ontworpen basis schema: 
Kortom de tamelijke gering BUPO-schending in schaal 2 leidt tot een militair conflict dat steeds gewelddadiger wordt en leidt tot zeer ernstige schendingen van de mensenrechten tot in schaal 5.

\section{Tunesië}

In Tunesië vindt gedurende de hele periode veel onderdrukking plaats. De regering heeft de repressie stevig in de hand en de onderdrukking is gericht tegen de specifieke groep in de politieke en maatschappelijke elite. Dat blijkt uit de terreurschaal die rond de 3/4 (in reikwijdte is de schending beperkt vanwege de selecte onderdrukte groep) schommelt en uit het hoge niveau van de aard van de schendingen van de burger- en politieke rechten die op niveau 5/6 zit. Opvallend is dat hierin geen verandering komt en de staatkundige hervormingen worden dan ook als cosmetisch beschouwd. Het instellen van een ministerie van mensenrechten klinkt mooi maar de leden van de liga van de mensenrechten en anderen worden er niet minder door vervolgd, gemarteld en soms buitenrechtelijk geëxecuteerd. Buitengerechtelijke executies en martelingen komen steeds voor met als belangrijkste verschil dat daar de laatste jaren iets meer over naar buiten komt. Naast de staatscensuur is er veel zelfcensuur bij de Tunesische media en ook de buitenlandse media wordt de toegang veelal ontzegd. Kinderarbeid vindt in Tunesië zowel op het platteland als in de stad plaats en ook hierin is geen verbetering te constateren. Het grote verschil met buurland Algerije is dat in Tunesië geen excessief geweld plaatsvindt met de vele doden.

\section{Mali}

Mali is de derde ex-Franse kolonie in Noord-Afrika die is onderzocht. Aan staten als Mali en Tunesië wordt in de internationale fora weinig aandacht besteed. Frankrijk weet haar oud-koloniën vaak goed te beschermen tegen een veroordeling. Katerina Tomasevski heeft dat onderzocht ${ }^{52}$ en Stanley Cohen formuleerde de zogenoemde Tsjaad regel die inhoudt

\footnotetext{
52 Katarina Tomasevski: Responding to Human Rights Violations, 1946-1999, Kluwer Law International, Martinus Nijhoff Publishers, The Hague/Boston/London, 2000, ISBN 90-411-1368-1, schrijft op p.
} 
dat niemand in Tsjaad geïnteresseerd is, nauwelijks weet waar het ligt en de voornamelijk in het Frans gesteld informatie voor velen niet toegankelijk is. In mijn vergelijkende pilotstudie kon ik dit bevestigen voor de zowel de informatie door staten in het bijzonder Nederland en Noorwegen en de NGO's als Amnesty International en Human Rights Watch. Amnesty International en Human Rights Watch melden over zowel 2000 als 2001 geen enkele schending van de rechten van de mens, Nederland meldt de slechte gevangenisomstandigheden en de kindermishandeling terwijl Noorwegen zich beperkt tot de melding over het tekort aan voedsel. Het State Department geeft de meeste informatie en toont Mali als een staat waar in 2001 de gevangenisomstandigheden slecht zijn, kinderarbeid en handel in kinderen voor kinderarbeid plaatsvindt naast sterke aanwijzingen voor foltering en buitengerechtelijke executies. Het schenden van de rechten van het kind is een constante in Mali en omvat bijna alle door ons onderzochte schendingen zoals de beperkte toegang van slechts $20 \%$ tot het basisonderwijs, kindermishandeling, Kinderarbeid inclusief gedwongen kinderarbeid en handel in kinderen ten behoeve van kinderarbeid, slechte gevangenisomstandigheden voor kinderen. De schendingen blijven in de niet gewelddadige tijden met een democratisch bestuur grotendeels tot deze schendingen beperkt hetgeen valt te constateren over de periode 1995-2002. De relatie tussen de schendingen van kinderrechten en armoede dringt zich weer op. Mali is interessant omdat het van 1991 op 1992 van een dictatuur in een democratie veranderde terwijl het geweld nog voortduurde. De voortduring van het geweld werd veroorzaakt door de strijd tegen rebellerende Toearegs met als gevolg voortdurende buitengerechtelijke executies (1990-1994). Maar met de democratisering werden andere burger- en politieke rechten nauwelijks nog langer geschonden hetgeen tot uiting komt in de abrupte daling van rond de 6 naar rond de 2 op de vrijheidsschaal bij de vergelijking van het dictatoriaal versus het democratisch bewind. Dit komt ook tot uiting in de sindsdien erkende vrijheid van vakvereniging en het stakingsrecht.

239:"Differently from publicity in Anglophone countries, French speaking African countries have been immune to international scrutiny.' Stanley Cohen, States of Denial, Polity, 2001, p. 173. 


\section{Georgië}

Georgië werd in 1992 onafhankelijk van de Sovjet Unie maar werd al snel geconfronteerd met afscheidingsbewegingen in Abchazië en Zuid-Ossetië - zo vielen er in de strijd om Abchazië in 1993 al meer dan duizend doden. Bovendien wilden in 1992 en 1993 de aanhangers van de afgezette president Zviad Gamsakhurdia de macht heroveren en daarmee nam het geweld in het land toe. Daarnaast kwamen er veel vluchtelingen uit Tsjetenië naar Georgië en het gevolg daarvan was instabiliteit en economische neergang. De economische neergang leidde tot andere schendingen van de rechten van de mens zoals de opkomst van straatkinderen en kinderprostitutie. Een jaar na de onafhankelijkheid bevond Georgië zich al op het hoogste geweldsniveau (MC 3) en gold de noodtoestand. Het geweld nam vervolgens af - mede dankzij de VN bemiddeling (de internationale omstander) voor een staakt-het-vuren - tot op het midden niveau in 1993/1994 (MC 2). Staatkundige hervormingen met een Grondwet en parlementsverkiezingen vonden in 1995 plaats en het geweld nam vervolgens verder af tot op het niveau van een gewelddadig politiek conflict met minder dan 100 doden per jaar (MC 1). De mate van geweld is gerelateerd aan de ernst en de reikwijdte van de schendingen van de rechten van de mens, zoals in onderstaande tabel is weergegeven.

\begin{tabular}{|l|l|l|}
\hline $\begin{array}{l}\text { Militair Conflict/ Mate van } \\
\text { geweld }\end{array}$ & Politieke terreur schaal/Pioom & $\begin{array}{l}\text { Burger- en Politieke Rechten/ } \\
\text { Freedom House }\end{array}$ \\
\hline MC 1 & $2-3$ & $3-4$ \\
\hline MC 2 & $2-3-4$ & $4-5$ \\
\hline MC 3 & $4-5$ & 5 \\
\hline
\end{tabular}

Wanneer we de verschillende schendingen in detail bekijken, is echter de afname in schendingen bij de vermindering van geweld nauwelijks meer te zien. Het aantal martelingen nam in ieder geval niet af nadien. Daarnaast stierven bijvoorbeeld in 199888 mensen in de gevangenis grotendeels als gevolg van fysiek misbruik, marteling en inhumane omstandigheden met onvoldoende bedden, voedsel, medische zorg. In feite is de 
situatie nog slechter omdat de aan de afscheidingsbeweging van Abchazië toe te rekenen schendingen niet eens zijn meegenomen.

\section{Kroatië}

Met het uitroepen van de onafhankelijkheid in 1992 brak de oorlog tussen de Serviërs en de Kroaten uit waarbij 9.000 doden vielen. Bemiddeling met de komst van VN vredesmachten leidde tot het einde van dit MC 3 conflict en de overgang naar MC 2 in 1993, en zelfs MC 1 in 1994 maar weer naar MC 3 in 1995 vanwege de hernieuwde strijd over de Servische enclaves die in 1995 door Kroatië werden ingenomen en waarbij ruim 600 Serviërs stierven. Vervolgens eindigde het geweld en de mensenrechtenschendingen op de Pioom schaal daalden ook van 5 naar $2 / 3$ terwijl buitengerechtelijke executies niet meer voor kwamen. Hoewel de grote oorlogsgerelateerde schendingen verdwenen zoals het opblazen van 10.000 huizen van Kroatische Serviërs bleven de schendingen ten aanzien van specifieke minderheden bestaan. Dat zijn in de eerste plaats de Moslims en de Serviërs (in 1995 vluchtten 200.000) aan wie het recht op terugkeer wordt ontzegd of de gedwongen huisuitzetting van degenen die bleven en discriminatie in huisvesting voor degenen met een Servische of gemengde Servisch/Kroatische achtergrond. Bij de toegang tot het onderwijs werden de Roma en degenen met een half Hongaarse achtergrond blijvend gediscrimineerd. Buiten deze kleinere schendingen kunnen we constateren dat de grotere schendingen van de rechten van de mens overduidelijk samenhingen met het hogere geweldsniveau ten tijde van de oorlogshandelingen.

\section{El Salvador}

De onderzoeksperiode start voor El Salvador in 1989 met de staat van beleg met zeer veel geweld (MC3 met meer dan 3000 doden) en een hoge mate van onderdrukking (terreurschaal 4) en dat duurt voort tot aan het vredesakkoord en de implementatie daarvan eind 1992. Vanaf 1993 kunnen we dan ook een verbetering constateren. Voor deze gewelddadige periode 1989-1992 hebben we Amerikaanse gegevens vergeleken met die van Amnesty International want voor deze periode was de Amerikaanse 
vooringenomenheid bekend en dat gold in het bijzonder voor die staten waar het zelf nauw bij betrokken was. De frequentie van de martelingen werd dan ook door AI hoger gezien dan door de VS.

De verbetering vanaf 1993 blijkt uit zowel het lagere niveau op de terreurschaal naar 3 en vervolgens naar 2 als uit de verbetering van de burger- en politieke rechten waardoor het vanaf 1997 zelfs als "vrij" (binnen de driedeling niet vrij, gedeeltelijk vrij en vrij) wordt beschouwd. Toch geven de meer gedetailleerde gegevens een minder rooskleurig beeld. Dat minder rooskleurige beeld heeft vooral betrekking op de sociaal-economische schendingen zoals die tot uiting komen in onvoldoende toegang tot het onderwijs en schendingen van de kinderrechten, kindermisbruik, kinderarbeid inclusief gedwongen kinderarbeid $^{53}$ en kinderprostitutie ${ }^{54}$ naast handel in kinderen voor kinderarbeid en kinderprostitutie en ook de ondervoeding heeft vooral betrekking op kinderen. De laatste jaren is rond de $20 \%$ van de kinderen ondervoed. Een voorzichtige conclusie is dat in El Salvador wel een verband is te constateren tussen de mate van geweld en de mate van schendingen van burger- en politieke rechten maar dat die relatie niet opgaat voor de sociaal economische rechten. De relatie tussen schendingen van beide categoriën mensenrechten is in vredestijd voor de armere landen veel minder aanwezig dan werd verondersteld.

\section{Paraguay}

In Paraguay start in 1989 de overgang van een militaire dictatuur naar democratie. Wel vindt continu enige onderdrukking plaats en het wordt als gedeeltelijk vrij beschouwd. Evenals bij El Salvador valt de flagrante schendingen van de rechten van het kind op alle terreinen op. Van 1993 tot en met 1997 leed zelfs de meerderheid van alle werkende kinderen - en vergeet daarbij niet dat een op de drie kinderen werkt - aan ondervoeding. Daarnaast trof de ondervoeding vooral de inheemse bevolking en juist deze selectiviteit

\footnotetext{
${ }^{53}$ Niettegenstaande de ratificatie op 15 juni 2000 van de ILO Conventie 182 inzake de ergste vormen van kinderarbeid.

${ }^{54}$ Volgens UNICEF bestaat in 200210 a $25 \%$ van de zichtbare prostitutie uit kinderen en vormen kinderen maar liefst $40 \%$ van de verborgen prostitutie.
} 
maakt dat van een sociaal economische schending gesproken kan worden waar de staat voor aansprakelijk is. Een bewering die - op basis van de "Maastricht principles" - nu wel voor Paraguay gedaan kan worden, waar dat voor Kenia nog niet zo goed mogelijk was. Discriminatie van minderheden is een vast patroon in Paraguay en werd geconstateerd voor Indianen, Chinezen en Koreanen, het betrof zowel de huisvesting als de toegang tot het onderwijs. De discriminatie betekent dan een schending voor beide categoriën rechten van de mens en vindt gelijktijdig plaats. Kortom, er is dan geen grond voor de aanname dat de ene categorie aan de andere voorafgaat.

\section{Thailand}

In Thailand grepen de militairen in 1991 en 1992 de macht. Demonstraties in Mei 1992, die weliswaar 52 mensen het leven kostte en waarbij 200 mensen verdwenen, leidden tot herstel van de democratische procedures. In de beide schalen wordt de onderdrukking uit 1991/1992 weerspiegeld. Echter ook nadien nemen de schendingen nauwelijks af want martelingen duren voort en veel buitenrechtelijke executies vinden tijdens voorarrest en in gevangenschap plaats terwijl de rechten van het kind evenmin verbeteren. Kindermisbruik, -arbeid, -prostitutie en handel in kinderen voor de prostitutie is ook een constante in Thailand.

\section{Sri Lanka en de Tamils}

In het conflict tussen de Tamiltijgers en de Singalezen zijn de afgelopen 19 jaar ruim 65.000 mensen om het leven gekomen. Dit zeer hoge geweldsniveau heeft zich nagenoeg over de gehele periode voorgedaan met uitzondering van een onderbreking in 1994/1995 vanwege een tijdelijk bestand en vervolgens het abrupt einde aan het conflict in 2002 vanwege het vredesverdrag en de erkenning van de Tamiltijgers $\left(\right.$ LTTE $\left.^{55}\right)$. Gedurende het

\footnotetext{
${ }^{55}$ Liberation Tigers of Tamil Eelam. In de tabellen hebben we de schendingen die aan de Tamil tijgers zijn toe te schrijven kunnen onderscheiden van de schendingen die aan de Sri Lankese overheid zijn toe te schrijven. De gegevens van het Freedom House betreffen geheel Sri Lanka en zijn voor de tabel over de Tamils weggelaten.
} 
hoge geweldsniveau was de onderdrukking ook maximaal volgens de PIOOM-schaal op niveau 4 en 5 terwijl die in 1994 en 2002 overeenkomstig lager waren met minder buitengerechtelijke executies. ${ }^{56}$ De direct oorlogsgerelateerde mensenrechtenschendingen zijn terug te vinden in het voedsel tekort vanaf 1999 vanwege de sluiting van de grenzen en de in beslagname van het voedsel door de Tamiltijgers waarmee het aan de bevolking in het Noorden werd onthouden. Anderzijds meldt "artsen zonder grenzen" dat ook in het oorlogsvrije Zuiden veel - vooral kinderen - aan ondervoeding lijden. In het gebied van de Tamils worden kinderen bovendien gedwongen tot arbeid dat geldt zowel voor de indirecte oorlogsinspanningen (loopgraven en bunkerbouw) als voor de directe oorlogsinspanningen als kindsoldaat. Kinderen worden door de LTTE al vanaf de leeftijd van 10 jaar gerecruteerd. De overige zeer massale en flagrante schendingen van de rechten van het kind op Sri Lanka komen eerder voort uit de armoede dan de oorlog en duren dan ook nog na het vredesverdrag voort. De tweeduizend kinderen die volgens de regering in de prostitutie zitten, zijn volgens andere bronnen nog geflatteerd want volgens de VN bedraagt dat aantal dertigduizend. In Sri Lanka vinden in het door de regering gecontroleerde gebied wel nog tamelijk vrije en eerlijke verkiezingen plaats waardoor de gegevens van het Freedom House gunstig afsteken bij de geconstateerde grove schendingen in de gevangenis, bij martelingen en buitengerechtelijke executies en de onderdrukking in het door de LTTE beheerste gebied.

\section{Israël en de Palestijnse gebieden}

In Israël binnen de groene lijn blijven de mensenrechtenschendingen in de periode 19892000 beperkt en vindt er weinig geweld plaats. De schendingen zijn vooral constant de beperkte toegang tot onderwijs en de discriminatie in huisvesting voor de Arabische Israëliërs. De weerslag van het geweld in de bezette gebieden tijdens de eerste Intifadah wordt niet weerspiegeld in Israël. Daarentegen heeft de tweede Intifadah wel degelijke zware gevolgen voor de situatie in Israël zelf. Er wordt op grotere schaal gemarteld, de

\footnotetext{
${ }^{56}$ Bij vergelijking van de buitengerechtelijke executies buiten de directe oorlogshandelingen over de jaren 1993, 1994 en 1995 zijn de cijfers: 80, 10, 72. Betrekken we daar de burgerslachtoffers bij, waaronder ook buitengerechtelijke executies zitten, dan zijn de aantallen: 250, 150 en vierhonderd.
} 
gevangenisomstandigheden verslechteren en buitengerechtelijke executies van 13 Arabische Israëliërs in 2000 bij een demonstratie vinden plaats. In 2000, 2001 en 2002 worden respectievelijk 22, 200 en 469 Israëliërs vermoord als gevolg van de zelfmoordaanvallen. De geweldspiraal verhevigt de al eerder geconstateerde schendingen. Kortom de schendingen in de meer vreedzame tijden zijn te zien als indicatoren voor de schendingen in de meer gewelddadige tijd.

Wanneer we naar de door Israël bezette gebieden kijken en de aan de staat Israël toe te schrijven schendingen in kaart brengen, constateren we een constante zeer slechte mensenrechtensituatie. In de periode 1989 tot 1995 tijdens de eerste Intifadah was het geweld hoog met een groot aantal buitengerechtelijke executies. Dit nam af in de daarop volgende periode tot september 2002 bij het uitbreken van de tweede Intifadah. In 2000, 2001 en 2002 zijn respectievelijk 307, 509 en 990 Palestijnen door het Israëlische leger gedood. De geweldspiraal heeft ook grote gevolgen voor andere mensenrechten schendingen. Zo constateren we voor de hele periode de gebrekkige toegang tot onderwijs omdat de Palestijnse universiteiten veelvuldig werden gesloten. Deze schending nam toe in omvang tijdens de gewelddadige jaren toen de noodklok werd ingesteld en schoolklassen voor een belangrijk deel gesloten waren of niet langer te bereiken. In deze oorlogsjaren 2000-2002 vinden gedwongen huisuitzettingen plaats, naast het vernietigen van huizen dat als de constante over de hele periode is te zien. Het meest zichtbare en direct aan de oorlogssituatie te relateren schending is het gebrek aan voedsel en water. De honger als gevolg van de oorlog vindt plaats in 2001 en 2002. De periode 1995-2000 was de beste periode in de bezette gebieden. Het Palestijns gezag kon in die periode aan de opbouw werken in het gebied dat aan hen werd over gedragen. Kijken we tenslotte naar de Palestijnse gebieden die door de Palestijnse autoriteit zijn bestuurd dan zien we eveneens de verslechtering van de laatste jaren. Martelingen, slechte gevangenisomstandigheden en buitengerechtelijke executies vonden ook al tevoren plaats maar verslechterde als gevolg van het geweld. Ook hier constateren we een constante in de belemmering op de toegang van het onderwijs voor Arabische meisjes maar de verslechtering nadien door de noodklok die we zo even constateerden maakte het voor alle scholieren en studenten vaak onmogelijk de school te bereiken. 


\section{CONCLUSIES VAN DIT ONDERZOEK TEN AANZIEN VAN VROEGTIJDIGE WAARSCHUWINGEN}

1. Er bestaat een samenhang tussen de mate van geweld en de mate van mensenrechtenschendingen.

2. Bij afname van geweld constateren we wel een afname van de burger- en politieke schendingen maar niet een afname van de economische en sociale mensenrechtenschendingen.

3. We vinden geen verband tussen het plaatsvinden van de burger- en politieke schendingen en de economische en sociale mensenrechtenschendingen.

4. We constateren evenmin dat het ene type schendingen voorafgaat aan het andere type schendingen.

5. Vroegtijdig optreden om schendingen op niveau twee in te dammen kan militair geweld voorkomen en kan een toename in de ernst, frequentie en reikwijdte van mensenrechtenschendingen eveneens voorkomen. 


\section{OMSTANDER}

$\mathrm{Nu}$ we kennis hebben kunnen nemen van vroegtijdige waarschuwingen, is het tijd de volgende stap te zetten naar vroegtijdig optreden. De vraag of en onder welke omstandigheden vroegtijdige waarschuwing ook tot vroegtijdig optreden zal leiden, wil ik de komende jaren gaan onderzoeken. Enkele gedachten over de richting van dat onderzoek kan ik nu naar voren brengen. Meer en meer staat de omstander en niet langer de dader centraal in onderzoek en educatie. Dat laatste heeft te maken met het gegeven dat we hoe langer hoe meer kennis nemen van wreedheden overal en daarmee de rol van de omstander vervullen. Transparante samenlevingen met massacommunicatie en spionage satellieten leggen zogezegd de hele wereld bloot. Daarmee worden we allemaal getuige en zitten in de rol van omstander. ${ }^{57}$

In het geval van genocide is de omstander verplicht dat te voorkomen en te bestraffen binnen de jurisdictie van de eigen staat. ${ }^{58}$ Een verplichting tot ingrijpen in een andere staat stond niet in de Genocide conventie uit 1948 maar uit de parlementaire debatten kwam naar voren dat men gebonden was al het mogelijke te doen doelgerichte massamoord uit te bannen. ${ }^{59}$ Dat kan de staat zelfstandig doen maar de staat kan ook de Verenigde Naties vragen maatregelen te nemen ter voorkoming of beëindiging van handelingen als het samenspannen of aanzetten tot genocide, het (mede) plegen van genocide en de pogingen

\footnotetext{
${ }^{57}$ Tony Kushner, 'Pissing in the Wind'? The Search for Nuance in the Study of Holocaust 'Bystanders' in: David Cesarani, Paul A. Levine (eds.) 'Bystanders' to the Holocaust: A Re-evaluation, London, 2002, p. 60.

${ }^{58}$ Artikel I, :"Genocide, whether commited in time of peace or in time of war, is a crime under international law which they [de staten die partij zijn] undertake to prevent and to punish.

${ }^{59}$ Samantha Power, 2002, p. 245-246, "The Convention's language was vague on precisely how the UN member states would meet their obligations, making no mention of military intervention and trusting that domestic prosecution of future 'genocidists' would deter massacres. Still the lively debates over ratification that occurred in national legislatures testified to the seriousness with which delegates believed they were committing their country's resources and prestige to banning targeted slaughter."
} 
tot genocide. ${ }^{60}$ In mei 1994 hebben bijvoorbeeld de Verenigde Staten bewust verme den de volkerenmoord in Rwanda ook genocide te noemen. ${ }^{61}$ De VS woordvoerder diende dat woord te vermijden en gebruikte in plaats daarvan genocidale gebeurtenissen en voorvallen. ${ }^{62}$ Stanley Cohen merkt op dat hoewel met het gebruik van de term genocide men nog niet verplicht is tot interventie, het weigeren deze term te gebruiken het gemakkelijker maakt niet te interveniëren. ${ }^{63}$ Samantha Power voegt daar aan toe dat zij ook het morele stigma verbonden aan deze ultieme moord wilden vermijden. ${ }^{64}$ Aangezien aanzetten tot genocide ook onder de genocide conventie vallen en discriminatie van etnische, raciale, nationale of godsdienstige groeperingen veelal aan genocide voorafgaan met inbegrip van dehumanisering van de medemens die eerder als object dan als subject

${ }^{60}$ Artikel II, III en VIII van het Verdrag inzake de Voorkoming en Bestraffing van Genocide, 9 December 1948 aanvaard in Parijs door de Algemene Vergadering van de Verenigde Naties en op 12 januari 1951 in werking getreden.

${ }^{61}$ A. Suhrke, and B, Jones, Preventive Diplomacy in Rwanda: Failure to Act or Failure of Actions, pp. 238264, uit: B.W. Jentleson (ed.), Opportunities Missed, Opportunities Seized. Preventive Diplomacy in the Post-Cold War World, Rowman \& Littlefield 2000.

${ }^{62}$ In Nederland verweet de CDA buitenland woordvoerder in de Kamer, Jaap de Hoop Scheffer, voor het TV-programma NOVA van 18 juli 1995 minister Pronk dat hij Srebrenica genocide noemde; uit: de Groene Amsterdammer, 11 oktober 2003 en NRC Handelsblad 23 september 2003. De dag na het interview vroeg De Hoop Scheffer aan premier Kok of de opmerkingen van minister Pronk wel sporen met het regeringsbeleid om in publieke uitlatingen terughoudenheid te betrachten met het oog op de Nederlandse VN militairen. Premier Kok antwoordde dezelfde dag dat de uitlatingen van Pronk niet met deze beleidslijn in strijd zijn. Tweede Kamer, 1994-1995, Aanhangsel, Vraag nr. 1071 van 19 juli 1995, p. 2205.

${ }^{63}$ Stanley Cohen, States of Denial; Knowing about Atrocities and Suffering, Polity, Cambridge, 2001, p. 162 "Although legal application of the term 'genocide' does not ensure intervention, a refusal to use the term makes it easier not to intervene".

${ }^{64}$ Samantha Power, Raising the Cost of Genocide, pp. 245-264 in The New Killing Fields, Massacre and the Politics of Intervention, Nicolaus Mills and Kira Brunner (eds.), Basic Books, Perseus Books Group, Oxford, 2002, p. 250 "This decision was made partly out of fear of triggering their [ze doelt hier op Europeanen en Amerikanen] obligations under the Genocide Convention, but mainly it was done to avoid the moral stigma associated with allowing what Lemkin described as 'the ultimate crime'." Zie verder Samantha Powers, Bystander to Genocide, The Atlantic Monthly, September 2001, p. 85. Zie ook: Michael Barnett, Eyewitness to a Genocide; The United Nations and Rwanda, Cornell University Press, Ithaca and London, 2002 en Samantha Power, A Problem from Hell; America and the Age of Genocide, Flamingo, London, 2002 met daarin hoofdstuk 10 Rwanda: "Mostly in a Listening Mode", pp. 329-389. 
wordt beschouwd - dringt zich de noodzaak maar ook de mogelijkheid weer op van vroegtijdig optreden. Zo is een norm en wetsbepaling in het Nederlands strafrecht dat je verplicht bent hulp te verlenen aan degene die in onmiddellijk levensgevaar verkeert. ${ }^{65}$ Deze verplichting voor de intermenselijke relaties binnen een staat kan niet zonder meer worden omgezet tot een verplichting in de internationale en interstatelijke betrekkingen. Toch redenerend vanuit een mensenrechten eigen "bottom up" gedachte dien je aan een mogelijke analogie evenmin voorbij te gaan. Wat mij betreft kan artikel 450 strafrecht [Hij die, getuige van het ogenblikkelijk levensgevaar waarin een ander verkeert, nalaat deze die hulp te verlenen of te verschaffen die hij hem zonder gevaar voor zichzelf of anderen redelijkerwijs te kunnen duchten, verlenen of verschaffen kan, wordt, indien de dood van de hulpbehoevende volgt, gestraft met..] als moreel uitgangspunt ${ }^{66}$ dienen en als rechtvaardigheidsgrond bij internationale interventie. Volgens sommigen zou dit op den duur kunnen uitgroeien tot internationaal gewoonterecht. ${ }^{67}$

De term omstander heeft een ongunstige (pejoratieve) betekenis gekregen. Veelal nog ongunstiger dan termen als voorbijganger, toeschouwer, buitenstaander, waarnemer of getuige. Omstanders worden dan gezien als degenen die onverschillig staan ten opzichte

\footnotetext{
${ }^{65}$ Art. 450 Wetboek van Strafrecht: Hij die, getuige van het ogenblikkelijk levensgevaar waarin een ander verkeert, nalaat deze die hulp te verlenen of te verschaffen die hij hem zonder gevaar voor zichzelf of anderen redelijkerwijs te kunnen duchten, verlenen of verschaffen kan, wordt, indien de dood van de hulpbehoevende volgt, gestraft met hechtenis van ten hoogste drie maanden of geldboete van de tweede categorie.

${ }^{66}$ Johannes Houwink ten Cate wijst in zijn oratie van 8 mei 2003 aan de Universiteit van Amsterdam , De naamgeving van de misdaad en de persoonlijkheid van de schrijftafelmoordenaar, op de verschillende dimensies van het begrip genocide waaronder ook de moreel-juridische naast de internationaalstrafrechtelijke dimensie.

${ }^{67}$ International Commission on Intervention and State Sovereignty, The Responsibility to Protect, Canada, December 2001, schrijft op p. 16 over "an emerging guiding principle in favour of military intervention for human protection purposes is also supported by a wide variety of legal sources" en op p. 50 "it may eventually be that a new rule of customary international law to this effect comes to be regocnized, but as we have already acknowledged it would be quite premature to make any claim about the existence now of such a rule".
} 
van de slachtoffers en een passieve houding innemen. Dit beeld komt tot uiting in de toeschouwer in Sighet door Elie Wiesel als volgt beschreven ${ }^{68}$ :

"Mijn ouders en ik stonden bij het hek. .... Toen opeens zag ik hém. Een gezicht achter het raam aan de overkant. ..... Een onbeduidend, alledaags, verveeld, gezicht: door geen enkele hartstocht aangedaan. Ik bleef er lang naar kijken. Hij keek naar buiten, drukte geen medelijden, geen vreugde, geen geschoktheid, zelfs geen woede of belangstelling uit. Onbewogen, koel, onpersoonlijk. Het schouwspel liet hem onverschillig. Wat! Die mensen gaan sterven? Dat is niet zijn schuld, kom nou; hij heeft de beslissing niet genomen. Hij is niet pro-joods en niet anti-joods: alleen maar een toeschouwer, dat is alles.

Zeven dagen lang liep de binnenplaats van de oude synagoge vol en weer leeg. Hij stond achter de gordijnen te kijken. De politieagenten sloegen vrouwen en kinderen: hij kwam niet van zijn plaats. Het ging hem niet aan. Hij was slachtoffer noch beul: getuige dat was hij. Hij wilde zijn rust. ...... De anderen, alle anderen, dat was hij. De derde hoek van de driehoek. Tussen slachtoffers en beulen bestaat een geheimzinnige band: zij behoren tot dezelfde wereld ....... Met de ander is dat echter niet zo. De getuige ontgaat ons geheel. Hij kijkt zonder gezien te worden. Hij is er zonder op te vallen. Het voetlicht beschermt hem. Hij applaudisseert niet, hij protesteert niet: zijn aanwezigheid is vaag, verplicht hem minder dan afwezig te zijn. Hij zegt geen ja en geen nee, ook geen misschien. Hij zegt niets. Hij is er, maar hij doet of hij er niet is. Erger hij doet alsof wij er niet waren." 69

In beginsel is de omstander noch dader, noch slachtoffer maar de derde partij die er wel bij aanwezig is of er zich bewust van zou kunnen zijn maar niet op voorhand tot de groepering van de daders of van de slachtoffers gerekend kan worden. In bovenstaand voorbeeld waar de omstander niet handelt, laat deze de dader zijn gang gaan en door niet te handelen

${ }^{68}$ Elie Wiesel die in 1986 de Nobelprijs voor de vrede (!) had ontvangen ontving in 2002 de hoogste onderscheiding van Roemenië (de orde van de ster van Roemenië). Bij deze uitreiking vroeg hij om meer ruchtbaarheid wat in de Tweede Wereldoorlog de Roemeense joden en Roma is aangedaan. NRCHandelsblad, 31 juli 2002. In oktober 2003 wordt Elie Wiesel benoemd tot voorzitter van een onderzoekscommissie naar de Shoa in Roemenië.

${ }^{69}$ Elie Wiesel, De stad van het geluk, Uitgeverij BZZToH, ’s-Gravenhage, 1987, pp. 136-137. 
maakt de omstander mogelijk dat de dader zijn wreedheden voortzet. Wiesel schreef: "Men was getuige van een ontzettende vereenvoudiging. Aan de ene kant de beulen, aan de andere kant de slachtoffers. En de toeschouwers, de neutralen? De neutralen helpen altijd de beulen, zuiver en alleen al door hen hun gang te laten gaan." 70

Het kan ook anders want er zijn ook omstanders die hun solidariteit tonen zoals Cleveringa indertijd. Job Cohen wees vorig jaar in zijn Cleveringa-lezing op de keuzemogelijkheid van de omstanders. ${ }^{71} \mathrm{Zij}$ kunnen de ander tot een vreemde bestempelen of zij kunnen deze het gevoel geven er bij te horen. Het "er bij horen" is wezenlijk voor de bevordering van de rechten van de mens. Theo van Boven schreef in dit verband over de praktijk van uitsluiting en de beginselen van insluiting. ${ }^{72}$

Een ander voorbeeld van een omstander die wel handelt is de onderduikgever in Nederland tijdens de Tweede Wereldoorlog. Ik citeer uit het werk "Daders, slachtoffers, omstanders" van Raul Hilberg: "Toen de transporten begonnen, bestond de voornaamste hulp die de joden geboden werd uit onderduikadressen. In deze samenzweerderige activiteit raakten de Nederlanders heel bedreven. Helpers werden door de Nederlandse ondergrondse aangemoedigd en financieel gesteund. Als ze gepakt werden hoefden ze niet bang te zijn

\footnotetext{
${ }^{70}$ Elie Wiesel: Een Jood, vandaag; Gooi en Sticht bv, Hilversum, 1978, p. 13. Zie ook Staub die stelde: "the bystander plays a central part in the establishment and maintenance of human rights abuses. By turning away or remaining passive in the face of threats to human life, the conditions for genocide are maximised." Geciteerd in A. Austin, 2003, p. 13. Uit zijn standaardwerk: E.Staub, The roots of evil - the origins of genocide and the other group violence, Cambridge, 1989 stelt hij aan de andere kant op p. 78 "Bystanders can exert powerful influence .... Even the behavior of governments can be strongly affected by bystanders individuals, groups or other governments. Repeatedly when they faced substantial opposition, the Nazis backed away. ....A lack of protest can confirm the perpetrators' faith in what they are doing."

${ }^{71}$ Job Cohen, Vreemden, Cleveringa-lezing op 26 november 2002, Universiteit Leiden.

72 Theo van Boven, Human Rights and Rights of Peoples, oorspronkelijk in European Journal of International Law, Vol. 6, 1995, pp. 461-476 en opgenomen in: Fons Coomans, Cees Flinterman, Fred Grünfeld, Ingrid Westendorp and Jan Willems (eds.), Human Rights from Exclusion to Inclusion; Principles and Practice - An Anthology from the Work of Theo van Boven, op p. 277 "It is the notion and principle of inclusion as opposed to the practice of exclusion ... which is to be regarded as a core idea of United Nations'approaches to human rights."
} 
dat ze automatisch de doodstraf kregen. Duizenden werden gearresteerd omdat ze joden of joodse eigendommen verborgen hielden, maar het Duitse beleid was om die mensen maar betrekkelijk korte tijd in een kamp in het land vast te houden en in ernstige gevallen hun bezittingen in beslag te nemen. ${ }^{73}$ Dit is een constatering achteraf en geeft nog geen inzicht in de verwachtingen vooraf over het risico dat onderduikgevers liepen. Verder onderzoek naar de rol van de omstanders in Nederland lijkt me erg gewenst waarbij ook de vele tegengestelde bevindingen nader geanalyseerd kunnen worden. ${ }^{74}$

Het voorbeeld vanuit Nederland contrasteert sterk met het voorbeeld uit de Oekraïne waar "iedere Oekraïner die een jood verborgen hield, zich aan acuut gevaar bloot stelde. Zo schoot een Duitse politiecompagnie in het dorp Samary, Volhynia, een hele Oekraïense familie dood - een man, twee vrouwen en drie kinderen - omdat zij een joodse vrouw in huis hadden." 75 De visie van de Duitsers op de Slavische Oekraïeners lijkt verschillend van die op de Germaanse Nederlanders in deze strafmaatregel. De positie van de omstander en

\footnotetext{
${ }^{73}$ Raul Hilberg:Daders slachtoffers omstanders; De joodse catastrofe 1933-1945, Becht, Haarlem, 1993, p. 184. Deze passage is gebaseerd op twee bronnen: Rapport van de commandant van de Sicherheitspolizei in Nederland over 1942 en van 15 augustus 1944. Gehaald uit National archives of the United States, record group 242, T 175, roll 670. Er wordt nog aan toegevoegd in deze noot op p. 273 "Per 13 augustus 1944 waren 1997 mensen geïnterneerd omdat ze joden hadden geholpen, zonder in staat van beschuldiging te zijn gesteld." Dit werd mij bevestigd (28-07-2003) door prof. dr. J. Houwink ten Cate, hoogleraar Genocide studies aan de Universiteit van Amsterdam: "Het is inderdaad waar dat gepakte onderduikgevers vanaf het najaar van 1943 standaard zes maanden KZ-Vught kregen, soms na verhoor in de Scheveningse Cellenbarakken. Hierover moet er een Erlass (verordening) van het RSHA zijn geweest, maar wij hebben de tekst ervan nooit kunnen vinden. Wij leiden dit dus af uit de systematische behandeling van individuele gevallen. Degenen die gearresteerd werden wegens illegaal werk in georganiseerd verband konden zwaarder worden gestraft."

${ }^{74}$ Te denken valt aan de discrepantie tussen de passiviteit van de meerderheid en de hulp van een kleine minderheid waarnaar koningin Beatrix in 1995 verwees, het bijzonder hoog aantal van 4.464 Yad Vashem penningen - een kwart van het totaal, op Polen na verreweg de meeste - dat aan Nederlanders werd toegekend, het relatieve hoogste percentage gedeporteerde Joden van alle West-Europese staten. Martin Gilbert, The Righteous - The unsung heroes of the holocaust, Doubleday, London, 2002, p. 402. Daarnaast stelt Gilbert op pag. 291: "For every Dutch person who helped a Jew there was another seemingly ready to betray the rescuers." Van de 25.000 ondergedoken Joden overleefden 16.000 de oorlog.

${ }^{75}$ Raul Hilberg, p. 176.
} 
het risico dat de omstander loopt verschilt per situatie en is mede afhankelijk van de rol die de dader voor de omstander in gedachte heeft. De voorzichtigere houding waarmee de Duitsers met de West-Europese omstanders omgingen verschilt eveneens met die in OostEuropa. In de woorden van Hilberg: "De joden uit Duitsland waren verscheept: ze werden niet aan de Rijn doodgeschoten. De joden van Riga en Kaunas waren echter vlak bij hun huis afgeslacht". ${ }^{76}$ Er werd gebruik gemaakt van de medewerking die omstanders konden bieden, omstanders die openlijk profiteerden van bijvoorbeeld het getto van Lvov. Hoe voorzichtig de eerste Duitse maatregelen tegen de Nederlandse Joden ook waren zoals de verplaatsing van Joodse musici van de voorgrond naar de achtergrond bij het Residentie orkest en het Concertgebouworkest of de verplaatsing van Joden uit de Hollandse kuststreek - er ontstond wel verzet zoals de februari-staking uit 1942 terwijl desondanks helaas het eindresultaat wat betreft de deportatie voor Nederland nog bedroevender was dan voor andere West Europese bezette staten.

Ook in de alledaagse situatie komen situaties van geweld en mishandeling veelvuldig voor waarbij derden niet ingrijpen. Een voorbeeld dat vaak wordt aangehaald is dat van Kitty Genovese die in 1964 op straat werd aangevallen en gedurende 40 minuten werd mishandeld. Ze schreeuwde en riep maar geen van de 38 mensen die haar hoorde, greep in of belde de politie. ${ }^{77}$ We hebben in dat geval, bekend onder de vreemde term "zinloze moord", te maken met de directe getuige. Een ander bekend voorbeeld van de stille getuige is het ophalen bij de buren van de dochter in Argentinië in een Ford Falcon toen de junta daar aan de macht was. In deze gevallen is de waarneming direct maar is de interpretatie van de gebeurtenis door de omstander van belang voor zijn houding. De oorspronkelijke vraagstelling verschuift van "wie wist wat" naar 1. Op welk moment werd de informatie ontvangen; 2. Hoe werd deze informatie geïnterpreteerd; en 3. Welke beslissingen werden

\footnotetext{
${ }^{76}$ Ibidem, p. 174.

77 Stanley Cohen 2001, pp. 3, 68-69, 143. Zie verder: A.M. Rosenthal, Thirty-Eight Witnesses: The Kitty Genovese Case, Berkeley, University of California Press, 1999. Alexander Austin stelt dat zij verkracht en vermoord is en wijst er op dat er minder snel hulp wordt geboden als het slachtoffer tot een andere groep behoort of tot een ver weg gelegen andere groep of wanneer er meerdere omstanders zijn. A. Austin, Early Warning and the Field: A Cargo Cult Science? In: Berghof Handbook for Conflict Transformation, 2003, p. 13.
} 
op grond daarvan al dan niet genomen. ${ }^{78}$ Met deze veranderde vraagstelling wordt de geschiedschrijving van de omstander steeds meer het verhaal van wat hij niet heeft gedaan. ${ }^{79}$ De schuldvraag wordt dan soms vooral bij de omstander gelegd en verdwijnt de dader uit het zicht. Zo omschrijft het Holocaust Museum in Washington in haar actie tot bewustwording van de bezoekers de omstanders als de onopzettelijke schuldigen. ${ }^{80}$

De rol van de omstander op individueel niveau is niet mijn onderzoeksonderwerp al schenk ik daar wel in het onderwijs veel aandacht aan, temeer daar een vroegtijdig bewustzijn kan leiden tot verzet op het moment dat zulks nog mogelijk is omdat de repressie niet verder is voortgeschreden. Hoefnagels heeft daarvoor een model opgesteld. ${ }^{81}$ Een model dat ook zeer bruikbaar is voor de rol van omstanders op het nationaal niveau. Wanneer zullen en/of kunnen derde staten ingrijpen is dan de vraag die ik nu stel.

\section{OMSTANDERS OP INTERNATIONAAL NIVEAU}

Ook op het internationaal niveau komt deze verschuiving inclusief de negatieve klank over omstanders terug. Ik zal dadelijk op de Nederlandse rol in Srebrenica ingaan maar eerst nog even aandacht vragen voor de omstanderstaten in de Tweede Wereldoorlog. Zo stelt Levine dat hoe minder je van de Shoa weet hoe meer je de Verenigde Staten en het Verenigd Koninkrijk prijst maar hoe meer je er van weet des te meer je bent geneigd hen te

${ }^{78}$ Raya Cohen, The Lost Honour of Bystanders? The Case of Jewish Emissaries in Switzerland, p. 149 in: Cesarani en Levine, 2002. Passage gebaseerd op Leni Yahil, The Holocaust, Oxford University Press New York, 1990.

${ }^{79}$ Ibidem, p. 150.

${ }^{80}$ Stanley Cohen, 2001, p. 167 citeert de directeur van dat museum:'The understanding of the passive bystander's inadvertent guilt is probably the most important and most relevant moral lesson the museum can teach to its visitors. Its importance lies in its broad applicability to contemporary historical and social phenomena as well as to occurrences in everybody's daily life." Uit: Jeshajahu Weinberg, From the Director, in Michael Berenbaum: The World Must Know: The History of the Holocaust as Told in the United States Holocaust Museum, Little, Brown \& Co., Boston, 1993, p. xv.

${ }^{81}$ Marjo Hoefnagels, Political violence and peace research, pp. 29-39 in: Repression and repressive violence, Amsterdam/Lisse, 1977. 
kritiseren voor wat ze deden en vooral wat ze niet deden. ${ }^{82}$ Te veel wordt dan de aandacht gericht op wat had behoren te gebeuren dan dat er een analyse plaatsvindt van wat is gebeurd. Zo'n interessante analyse werd verricht door een Amerikaanse aio, Meredith Hindley, die de geallieerde reacties op de Shoa met die op de voedselschaarste vergeleek. ${ }^{83}$ Voor de geallieerden telde bovenal de oorlogsvoering en dat betekende dat zij in geen geval mochten meewerken aan een versterking van de Duitse oorlogsinspanning ${ }^{84}$ Het redden of helpen van burgers was daar aan ondergeschikt. ${ }^{85}$ Het embargo op voedsel naar Europa werd gehandhaafd vanuit de overtuiging dat het de taak van de Duitsers was de bevolking, ook in de bezette gebieden, van voedsel te voorzien en Churchill zei in het Britse parlement dat de voedselblokkade ook voor bezet Frankrijk om die reden werd gehandhaafd. ${ }^{86}$

Ook het Joods Wereld Congres volgde deze lijn en stuurde bijvoorbeeld in 1941 geen voedselpaketten naar het ghetto van Warschau terwijl $10 \%$ in 1941 door uithongering stierf. ${ }^{87}$ Een andere joodse hulp organisatie RELICO stuurde wel voedselpakketten die ook allemaal op de juiste bestemming aankwamen. Het beleid was een sanctie politiek te volgen met het oog de tegenstander te verzwakken op economisch terrein en daarmee aan gevechtscapaciteit te laten inboeten. ${ }^{88}$ Ook Hilberg trekt deze conclusie uit het beleid van de geallieerden in de Tweede wereldoorlog ${ }^{89}$ : "De westerse geallieerden wilden niet dat hun eigen bevolking de oorlog zag als een poging de joden te bevrijden. Er mocht geen toespeling gemaakt of impliciete conclusie getrokken worden dat de geallieerde troepen

${ }^{82}$ Paul A. Levine, Attitudes and Action: Comparing the Responses of Mid-level Bureaucrats to the Holocaust, p. 212 in: Cesarani en Levine, 2002.

${ }^{83}$ Meredith Hindley, Constructing Allied Humanitarian Policy, pp. 77-102 in: Cesarani en Levine, 2002.

${ }^{84}$ Ibidem, p. 85.

${ }^{85}$ Ibidem, p. 79.

${ }^{86}$ Ibidem, p. 87, Curchill in House of Commons op 20 Augustus 1940.

${ }^{87}$ Raya Cohen, The Lost Honour of Bystanders? The Case of Jewish Emissaries in Switzerland, p. 161 en 165 in: Cesarani en Levine, 2002.

${ }^{88}$ Bij de sancties tegen Irak van de afgelopen 13 jaar kan dat ook een rol hebben gespeeld. De sancties tegen Irak werden ingesteld op 2 augustus 1990 met S/RES/661 en werden beëindigd op 22 mei 2003, S/RES/1483 Zie ook: Fred Grünfeld, Sancties, Ars Aequi, 51 (2002) 7/8, pp. 93-101.

${ }^{89}$ Raul Hilberg, Daders, Slachtoffers , Omstanders; De Joodse Catastrofe 1933-1945, Becht, Haarlem, 1992, p. 223. 
huursoldaten voor de joodse zaak waren. Het was al moeilijk genoeg om een Brit of Amerikaan uit te leggen waarom er oorlog werd gevoerd.... Gezien dit standpunt kon de bevrijding van de joden slechts een nevenproduct van de overwinning zijn."

Interessant is vervolgens de rol van een omstanderstaat te bestuderen die niet bij de militaire strijd was betrokken. Zweden bijvoorbeeld stelde zich tot 1942 uiterst terughoudend op ten opzichte van de Jodenvervolging. Het liet nauwelijks vluchtelingen to $^{90}$ mede omdat het bevreesd was voor de eigen werkgelegenheid en een verstoring van de handel met nazi Duitsland. ${ }^{91}$ In november 1942 wordt het Zweedse beleid radicaal gewijzigd en dat heeft alles te maken met de deportatie van achthonderd Joden uit Noorwegen. ${ }^{92}$ Een belangrijke rol werd daarbij vervuld door de Zweedse onder secretarisgeneraal bij het ministerie van Buitenlandse Zaken, Gösta Engzell, die al eerder was geïnformeerd over de uitroeiing in Mauthausen, Lodz, Belzec, de Baltische staten maar pas tot een actieve radicale beleidswijziging kwam nadat op 26 november 1942 de deportatie per boot van 532 mannen, vrouwen en kinderen uit Noorwegen voorpagina nieuws werd. ${ }^{93}$ Binnen een week verklaarde Zweden alle overgebleven Joden uit Noorwegen op te willen vangen. Noorse Joden behoorden tot verwante Scandinaviërs. ${ }^{94}$ Onverschilligheid was geen optie meer. ${ }^{95}$ Nadat deze drempel eind 1942 genomen was, werd het beleid zo veel mogelijk Joden te redden en volgden de reddingspogingen van de Deense Joden in 1943, de Hongaarse Joden in 1944 - door onder meer Raoul Wallenberg - en vervolgens werden

\footnotetext{
${ }^{90}$ Zweden telde in 1939 twee duizend Joodse vluchteling, evenveel als Luxemburg op dat moment. Paul A. Levine, Attitudes and Action: Comparing the Responses of Mid-level Bureaucrats to the Holocaust, p. 219 in: Cesarani en Levine, 2002.

${ }^{91}$ Sven Nordlund: 'The War is Over - Now You Can Go Home!' Jewish Refugees and the Swedish Labour Market in the Shadow of the Holocaust, pp. 171-198 in: Cesarani en Levine, 2002.

${ }_{92}$ Karen Kvist, A Study of Antisemitic Attitudes within Sweden's Wartime Utlänningsbyrân, pp. 207-208.

93 Paul A. Levine, Attitudes and Action: Comparing the Responses of Mid-level Bureaucrats to the Holocaust, p. 225 in: Cesarani en Levine, 2002.

${ }^{94}$ Ibidem, p. 226.

95 Paul A. Levine, Attitudes and Action: Comparing the Responses of Mid-level Bureaucrats to the Holocaust, p. 227 in: Cesarani en Levine, 2002.
} 
in 1945 nog zoveel mogelijk mensen met bussen $^{96}$ - mede georganiseerd door Folke Bernadotte - uit de kampen gehaald waaronder drie duizend vrouwen uit Ravensbrück.

Afgelopen jaar speelde de vraag naar de rol van Nederland in de kwestie Srebrenica. Deze verantwoordelijkheid werd door de regering Kok zo hoog opgevat dat het Kabinet Kok besloot af te treden, een unieke gebeurtenis die mijns inziens te weinig aandacht heeft gekregen. Ik citeer nu uit de regeringsverklaring die Kok op 16 april 2002 uitsprak: ${ }^{97}$

"Ik ben tot de slotsom gekomen dat de ernst van de bevindingen van het NIOD .... niet zonder politieke consequenties mag blijven ${ }^{98}$...... Het NIOD-rapport is volstrekt duidelijk over de vraag wie verantwoordelijk moet worden gesteld voor de val van Srebrenica en de daarop volgende massamoord; de schuld daarvoor ligt bij de Bosnische Serviërs, in het bijzonder bij generaal Mladic. .....De internationale gemeenschap is tekortgeschoten in het bieden van voldoende bescherming aan de mensen in de "safe areas". Daarmee is ook de Nederlandse regering als lid van die internationale gemeenschap tekortgeschoten. De consequenties die thans worden getrokken zijn niet verbonden aan één specifieke gebeurtenis of één specifiek moment, maar vloeien voort uit de opeenstapeling van tekortkomingen gedurende verschillende kabinetsperiodes. Met dit besluit wordt integraal verantwoordelijkheid genomen voor het gevoerde beleid gedurende een reeks van jaren..... Nederland neemt uitdrukkelijk niet de schuld op zich voor de gruwelijke moord op duizenden Bosnische moslims in 1995. Wél wordt op deze wijze de politieke medeverantwoordelijkheid van Nederland voor de situatie waarin dit kon gebeuren, zichtbaar gemaakt. "De internationale gemeenschap" is anoniem en kan niet op een zichtbare manier verantwoordelijkheid nemen tegenover de slachtoffers en nabestaanden van Srebrenica. Ik kan en doe dat wel." 99

Nederland is uitdrukkelijk niet de dader maar wel medeverantwoordelijk. Een omstander die er bij betrokken was en derhalve medeverantwoordelijk is. Bij de behandeling van het

\footnotetext{
${ }^{96}$ Sune Persson, Folke Bernadotte and the White Buses, pp. 237-268, in: Cesarani en Levine 2002.

${ }^{97}$ Kamerstukken 28506 heeft betrekking op het rapport van de Enquêtecommissie Srebrenica terwijl 26122 betrekking heeft op het NIOD rapport. Verklaring Minister President Kok over aftreden kabinet, Handelingen 2001-2001, nr. 68 (16-4-2002), Tweede Kamer, p. 4539-4541.

${ }^{98}$ Ibidem p. 4539.

${ }^{99}$ Ibidem, p. 4540.
} 
rapport van de parlementaire enquêtecommissie zei Balkende op 18 juni 2003 in de Tweede Kamer: ${ }^{100}$

"Dat brengt mij bij het moeilijke vraagstuk van schuld en verantwoordelijkheden....Ik wil wel duidelijk zijn over het standpunt van de regering. Vanuit moreel en ethisch oogpunt zijn de daders van de massamoord schuldig. ...Het is van allergrootste belang dat zij ook in juridische zin schuldig worden bevonden. De regering blijft zich inspannen om de daders voor het Joegoslavië-tribunaal te krijgen.... Naast schuld is er verantwoordelijkheid. Deze ligt bij de schuldigen, maar daarnaast ook bij de internationale gemeenschap en de staten die daarvan deel uitmaken."101

\section{Vervolgens vraagt Marijke Vos van GroenLinks of de verantwoordelijkheid ook inhoudt dat Nederland excuses zal gaan aanbieden:}

"Natuurlijk ligt de schuld bij Mladic en de Serviërs. Daar bestaat geen twijfel over. Nederland draagt echter wel verantwoordelijkheid en Nederland is tekortgeschoten in de bescherming die het had moeten bieden aan de bewoners aldaar. In dat licht lijkt het mij zeer goed mogelijk om excuses aan te bieden, zonder dat daarmee de schuld die bij de Serviërs ligt op de schouders wordt genomen. Dat vraag ik de regering." ${ }^{\prime 02}$

\section{Balkenende antwoordt daarop:}

"Wij voelen de pijn van de bevolking en wij dragen onze medeverantwoordelijkheid, maar excuses moeten in relatie worden gezien met de schuldvraag ${ }^{103} \ldots$ de schuldigen daarvan zijn de moordenaars en hun superieuren. Ik wil in geen geval de indruk wekken dat de schuldvraag elders komt te liggen dan waar die hoort. Die indruk zou kunnen ontstaan bij het aanbieden van excuses. Ik wil de heer Eurlings (CDA) hier naspreken die gisterenavond in een interruptie debatje zei dat Nederland in ieder geval met goede bedoelingen heeft getracht iets te doen aan de wreedheden in Bosnië. Veel landen lieten de beker aan zich voorbijgaan. Nederland hoeft zich niet op de borst te slaan, zeker niet gelet op de gebeurtenissen in 1995, maar excuses vind ik niet de juiste vorm waarin ook dit kabinet de medeverantwoordelijkheid voor de

${ }^{100}$ Voortzetting van de behandeling van het Rapport van de Enquêtecommissie Srebrenica (debat met de Regering), Handelingen 2002-2003, nr. 79 (18-6-2003), p. 4473-4529.

${ }^{101}$ Ibidem, p. 4475.

${ }^{102}$ Ibidem, p. 4478.

${ }^{103}$ Ibidem. p. 4478 na de vraag van mevrouw Vos. 
ontstane situatie meent te moeten dragen...... Het aanbieden van excuses behoort bij het dragen van schuld.... Dat is, wat mij betreft, een stap te ver."104

De rol van omstander is aangescherpt. Het kabinet Balkenende herhaalt de medeverantwoordelijkheid en schaart zich volledig achter de door het kabinet Kok gevolgde lijn. Geen Nederlands Kabinet is eerder door het parlement ten val gebracht of is afgetreden vanwege een onderwerp uit de buitenlandse politiek. Ditmaal was Nederland omstander bij de gruwelijke gebeurtenissen in Srebrenica en voelt zich als deel van de internationale gemeenschap - deelnemer aan de VN vredesmach - mede verantwoordelijk. Het Kabinet treedt af, een unieke gebeurtenis die het belang van de rol van de omstander nog eens onderstreept.

\section{De Verenigde Naties}

De belangrijkste internationale omstander, de vertegenwoordiger bij uitstek van de internationale gemeenschap, is de Verenigde Naties. Deze Verenigde Naties en dan in het bijzonder haar belangrijkste orgaan de Veiligheidsraad (VR) heeft alleen in een zeer nauw omschreven situatie mandatoire bevoegdheden. Deze situatie bevindt zich niet aan het prille begin van de conflictsituatie of mensenrechtenschending maar de dreiging dat vrede en veiligheid in het geding is, moet manifest zijn. Dat wil niet zeggen dat er al gevochten moet worden (vredesbreuk of agressie) voordat de VR kan gaan optreden maar toch worden deze mandatoire bevoegdheden meestal niet gezien in het kader van de preventie. Alleen al het onderscheid tussen hoofdstuk VI en hoofdstuk VII van het Handvest geeft dat aan. Toch beweer ik hier dat dat wel kan, zeer gewenst is en juist in deze tijd noodzakelijk is. Het kan zowel juridisch als politiek, het is zeer gewenst en in overeenstemming met de doeleinden van de Verenigde Naties waarbij de bescherming van de Rechten van de Mens en het bewaren van de internationale vrede en veiligheid samengaan. ${ }^{105}$ Van der Stoel

\footnotetext{
${ }^{104}$ Ibidem, p. 4478 voorafgaand aan de vraag van mevrouw Vos.

${ }^{105}$ Zie daartoe vooral de preambule van het Handvest naast artikel 55 van het Handvest van de Verenigde Naties.
} 
verzet er zich eveneens tegen dat pas zou kunnen worden ingegrepen bij "onomstotelijk vaststaande systematische schendingen van de mensenrechten van de meest ernstige aard" ${ }^{106}$ want dan misken je de VN doelstelling van de bescherming van de mensenrechten. Anderzijds bestaat er ook het gevaar dat er wèl wordt ingegrepen op grond van "vermeende, maar onvoldoende overtuigend aangetoonde schendingen van de mensenrechten". ${ }^{107}$ Ook Menno Kamminga wees in zijn oratie - twee jaar geleden - op het gevaar van misbruik wanneer buiten de VN om uit humanitaire overwegingen wordt ingegrepen. Hij zei: "De pijlers van het internationaal recht zijn er niet voor niets." ${ }^{108}$ Kofi Annan stelde in zijn toespraak op 23 september 2003 voor de Algemene Vergadering van de Verenigde Naties eveneens dat met unilaterale acties of ad hoc coalities zonder VN toestemming aan de beginselen van de afgelopen 58 jaar voor vrede en stabiliteit wordt getornd. Dat kan leiden tot een verspreiding van eenzijdig, onrechtmatig gebruik van geweld. De Veiligheidsraad dient zich daarover te buigen en "need to begin a discussion on the criteria for an early authorisation of coercive measures to address certain types of threats .... And they still need to engage in serious discussions of the best way to respond to threats of genocide or other comparable massive violations of human rights". ${ }^{109}$

Kortom vroegtijdig optreden met dwangmaatregelen tegen bepaalde bedreigingen inclusief de dreiging van genocide of andere vergelijkbare grootschalige mensenrechtenschendingen staat hoog op de internationale agenda. Het vanuit deze leerstoel te ondernemen onderzoek lijkt me dan ook relevant. Ik sluit af.

\footnotetext{
${ }^{106}$ M. van der Stoel, Conflictpreventie - de lessen van Kosovo en Macedonië, oratie, universiteit van Tilburg, 25 januari 2002, p. 14.

${ }^{107}$ M. van der Stoel, Conflictpreventie - de lessen van Kosovo en Macedonië, oratie, universiteit van Tilburg, 25 januari 2002, p. 15.

${ }^{108}$ Menno T. Kamminga, De humanisering van het volkenrecht, oratie van 23 maart 2001 aan de Universiteit Maastricht, p. 15.

${ }^{109}$ The Secretary-General Address to the General Assembly, New York, 23 September 2003.
} 
Aanwijzingen voor op handen zijnde gewelddadige conflicten en grootschalige mensenrechtenschendingen zijn over het algemeen beschikbaar. ${ }^{110}$ De betrouwbaarheid van deze aanwijzingen is - met name door de terugslag van de vermeende massavernietigingswapens in de aanloop tot de oorlog in $\operatorname{Irak}^{111}-$ nog wel een punt van zorg. Een groter probleem is echter de omzettingen van waarschuwingen in actie, kortom het optreden van de omstander zelf. De politieke mobilisatie in de staten van de omstanders om tot optreden te komen bij voorkeur in internationaal verband, vergt de meeste aandacht. Het serieus nemen van de eerste signalen, temeer als die niet in het bestaande beeld passen, is een groot probleem. Veelal schuiven politici dat het liefst voor zich uit. Met mislukte interventies verlies je de verkiezingen in eigen land terwijl een succesvol vroegtijdig optreden zich vaak aan het zicht zal onttrekken. Zelfs wanneer de besluitvormers ervan overtuigd zijn dat met hun vroegtijdig optreden een ramp is voorkomen is dat moeilijk te bewijzen en win je daar de verkiezingen niet mee. Het is moeilijk steun te verwerven voor vroegtijdig optreden terwijl juist dan de kans op succes het grootst is. ${ }^{112}$ Pas bij verdergaand geweld en zeer ernstige mensenrechtenschendingen klinkt de roep voor interventie maar op dat moment is het moeilijker, kostbaarder en met meer risico's op mislukking omkleed. ${ }^{113}$ Hoe langer je wacht, hoe moeilijker het ingrijpen wordt maar pas dan verwerf je voor dat optreden politieke steun onder de eigen bevolking. Al lijkt met vroegtijdig optreden het beste resultaat tegen de minste kosten te kunnen worden bereikt, het ligt het minst voor de hand dat zo'n optreden ook daadwerkelijk zal plaatsvinden. Een onderzoeksonderwerp waar ik als politicoloog de komende jaren graag mijn tanden in wil zetten en waar deze leerstoel mij de gelegenheid voor biedt.

\footnotetext{
${ }^{110}$ Ik verwijs naar Zweden in de Tweede Wereldoorlog en de Verenigde Naties in de aanloop tot de genocide in Rwanda.

${ }^{111}$ Deze oorlog startte op 20 maart 2003 en werd op 1 mei 2003 als beëindigd beschouwd.

112 B.W. Jentleson (ed.). Opportunities Missed, Opportunities Seized. Preventive Diplomacy in the PostCold War World, Rowman \& Littlefield, 2000.

${ }^{113}$ Ibidem, pp. 21-38, A.L. George en J.E. Holl, The Warning-Response Problem and Missed Opportunities in Preventive Diplomacy.
} 


\section{DANKWOORD}

Enkele mensen kan ik in de nog beschikbare tijd bedanken, de anderen graag na afloop van deze oratie.

Graag wil ik het bestuur van de Stichting PIOOM bedanken voor deze leerstoel en mijn benoeming. De Stichting PIOOM staat voor Stichting ter Bevordering van Projecten voor Interdisciplinair Onderzoek naar de Oorzaken van Mensenrechtenschendingen. In het bijzonder wil ik de vorige en huidige voorzitter Ellie Lissenberg en Johan Scholten voor hun inspanningen bedanken. Graag betrek ik hier het College van Curatoren voor deze bijzondere leerstoel bij, dat mij voor deze benoeming heeft voorgedragen en op deze leerstoel en mijn functioneren toezicht houdt. Toen Ellie Lissenberg namens het College van Curatoren mij bijna drie jaar geleden belde over het vertrouwen in mij voor het bezetten van deze leerstoel, zei ik haar mij zeer verheugd en vereerd te voelen. Ik kan u zeggen dat ik dat nog steeds zo voel.

Het College van Bestuur en de Faculteit der Rechtsgeleerdheid van de Universiteit Utrecht wil ik bedanken dat zij met de vestiging van deze leerstoel en met mijn benoeming hebben ingestemd. Daartoe zijn zij geadviseerd door het college van promoties en de zusterinstellingen die ik eveneens dank. Het College van Bestuur is niet over een nacht ijs gegaan met deze benoeming.

Een benoeming die mogelijk is gemaakt door de enthousiaste en voortvarende medewerking vanuit Maastricht. In het bijzonder wil ik hiervoor de decaan indertijd Gerard Mols en mijn vakgroep voorzitter Menno Kamminga bedanken.

Ik ben de tweede bekleder van deze leerstoel. Op woensdag 10 december 1997 hield Piet van Reenen vanaf deze plaats zijn oratie. Hij heeft het onderzoek op het terrein van politie en mensenrechten opgezet en uitgebouwd. Ik zal mijn best doen jou na te volgen in deze leerstoel weliswaar op een ander terrein. Fijn dat jouw professoraat wordt voortgezet. 
Aan onderwijs en onderzoek op het terrein van de mensenrechten in internationaal en nationaal verband heb ik de afgelopen jaren kunnen meewerken. In internationaal verband is dat het European Master Programme in Human Rights and Democratisation en ik wil daar graag de voorzitters Horst Fischer en Manfred Nowak voor bedanken. In nationaal verband heeft de samenwerking binnen de onderzoekschool voor de rechten van de mens mij enorm gestimuleerd. De voorzitter Willem van Genugten, wil ik daar graag dank voor zeggen. Utrecht is gelukkig bij beide verbanden betrokken en zo kan ik deze samenwerking in de onderzoekschool en EMA/EJUC ook vanuit hier voortzetten.

De Stichting Albert Horstman Fonds heeft zich bereid verklaard het onderzoek dat ik vanuit deze leerstoel verricht naar staten en internationale organisaties als omstanders bij het ontstaan van grootschalige fundamentele mensenrechtenschendingen financieel te ondersteunen. Ik ben bijzonder dankbaar voor deze steun en de belangstelling die tot uiting kwam in het contact met Ies Heertje. De financiële steun is bestemd voor onderzoeksassistentie waardoor het afgelopen jaar Jan de Vries en Selke Schimmel konden worden aangesteld. Ik wil Jan en Selke graag bedanken voor deze wezenlijke assistentie.

Studenten. Het geven van onderwijs is de enig vastgelegde taak voor deze leerstoel. In deze ook maatschappelijk gerichte leerstoel staat in het onderwijs een bewustzijn van de processen tot onderdrukking in een vroeg stadium centraal. Het vroegtijdig onderkennen van die mechanismen maakt het mogelijk verzet aan te tekenen op het moment dat zo iets ook beter mogelijk is. In Maastricht ben ik met en op initiatief van Alette Smeulers dit onderwijs op gaan zetten. Graag wil ik Alette daarvoor dank zeggen. Mijn voorkeur voor interactie in kleine groepen neem ik vanuit Maastricht naar Utrecht mee en daar heb ik al enige ervaring mee bij de Faculteit der Rechtsgeleerdheid en het University College in beide steden. Gelukkig zijn er steeds veel studenten in dit onderwerp geïnteresseerd, zo wordt dit onderwijsblok op dit moment gegeven aan het University College Maastricht, aan het Post Doctorale MIC programma ${ }^{114}$ in Maastricht en in het Masters programma in

${ }^{114}$ MIC staat voor Magister Iuris Communis een Master in Comparative, European and International Law (LL.M.) en het onderwijs vindt plaats binnen de specialisatie Globalisation and Human Rights. 
Utrecht voor Socrates en LLM studenten. Het trekt nu al in Utrecht ruim 50 studenten. Het enige vreemde is dat ik nu Nederlands spreek terwijl dat in het onderwijs steeds Engels is.

Educatie is gestart door mijn ouders in een prettig milieu met veel affectie thuis. In mijn opvoeding stonden kennis, cultuur, non-discriminatie en maatschappelijk bewustzijn voorop. Bijzonder vind ik ook dat mevrouw Verwey-Jonker, die vandaag hier aanwezig is, niet alleen aan de wieg stond van de Universele Verklaring van de Rechten van de Mens maar haar naam stond ook op het vals persoonsbewijs van mijn ouders waarmee zij in 1943 naar een ander onderduikadres konden reizen. ${ }^{115}$

Docenten hebben zich voor mij ingezet van jongs af aan. Bijzonder neutraal basisonderwijs, rooms-katholiek middelbaar onderwijs, gereformeerd universitair onderwijs volgden. Zelf verkoos ik aan openbare universiteiten in Leiden, Maastricht en nu in Utrecht te gaan werken.

In Leiden zette ik mijn eerste stappen op dit terrein bij de B4 werkgroep onder de inspirerende leiding van Philip Everts. De vier B's staan voor binnenlandse beïnvloeding van het buitenlands beleid, een fantastisch interuniversitair samenwerkingsverband. Zonder B4 zou ik nu geen wetenschapper zijn.

In Maastricht nam ik deel aan de spannende uitbouw van een Faculteit met veel vernieuwing en mogelijkheden tot ontplooiing. Met vele vrienden en collega's, waaronder Jan Willems en Fons Coomans, werk ik daar samen in onderwijs en onderzoek op het terrein van de rechten van de mens. Jan en Fons, ik wil dat graag met jullie en anderen van internationaal recht uit Maastricht als Ingrid Westendorp, Menno Kamminga en Koen de Feyter voortzetten.

Degenen die betrokken waren bij mijn promotie in 1991 hebben mij ook nadien gestimuleerd. Ik noem graag de paranimfen Rob Bakker en Huub Winthagen, de leescommissie Joop Ellemers, Fred van Staden en Job Cohen en vooral mijn drie promotores Theo van Boven, Cees Flinterman en Peter Baehr

${ }^{115}$ Ongepubliceerd Dagboek van Wilma Grünfeld-van Dam, 1942-1943. 
Theo jouw maatschappelijke gedrevenheid, verwondering en verbazing over het wereldgebeuren in combinatie met de menselijke maat en warmte van jou en Anne-Marie hebben mij gesterkt.

Cees, jij ging mij voor zowel op je reis van Leiden naar Maastricht als van Maastricht naar Utrecht. Jouw belangstelling en enthousiasme is steeds groot en dat stimuleert. Ik verheug me erop met jou en de andere medewerkers in het multidisciplinaire verband van zowel het SIM als de Onderzoekschool opnieuw en intensief samen te werken.

Peter ik voel mij bevoorrecht dat jij niet alleen mijn promotor wilde zijn, van wie ik veel heb geleerd, maar mij ook de gelegenheid bood nadien samen met jou en Monique Castermans een boek te schrijven over de mensenrechten in het buitenlands beleid van Nederland. Ik zie je als het politicologisch mensenrechtelijk rolmodel met fijnzinnigheid, humor en wijsheid. En dat is wat mij betreft niet te veel eer, al zal je daar zelf in al je bescheidenheid misschien anders over denken

De familie is een vertrouwde omgeving. Ik ben blij dat mijn oom Frans, de Prof. Dr. F. Grünfeld uit Goirle bij deze oratie aanwezig is. Mijn beide zusjes Joyce en Nynke wil ik ook noemen. Mijn beide zonen Joram en Samme: Samme met jouw humor en sociale vaardigheden en Joram met jouw grote interesse en betrokkenheid vormen jullie de kern van mijn bestaan. Ten slotte mijn grootste liefde: Marij. Ditmaal mag ik jou noemen omdat niemand kan denken, nu de zonen eenmaal het huis uit zijn, dat het schrijven van deze oratie ten koste is gegaan van mijn zorgtaken thuis. Jouw emancipatiedrang, belette me je in mijn dissertatie te bedanken. Nu mag ik dat gelukkig wel, en dan wil ik voorop stellen dat bij jou het kernbegrip van de mensenrechten, de menselijke waardigheid en het volmondig respect voor de medemens steeds gewaarborgd is. Daarmee, en met nog heel veel meer, maak je mij als jouw naaste heel gelukkig.

Ik heb gezegd. 


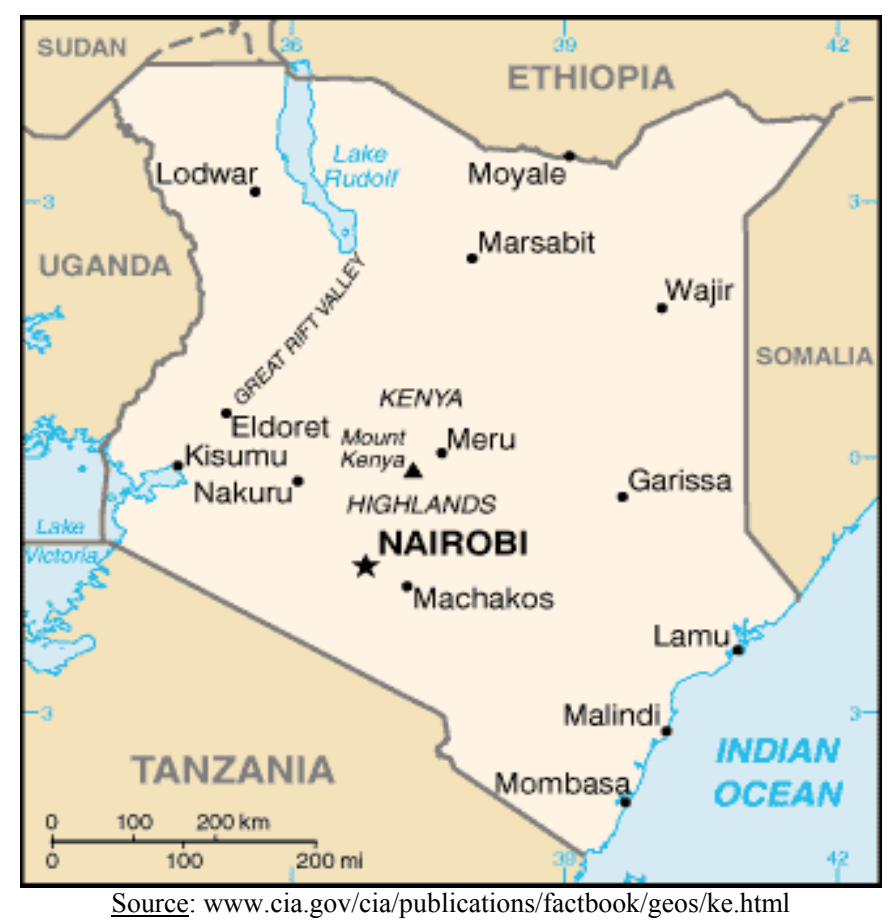

KENYA

(population: 31,639,091)

\begin{tabular}{|c|c|c|c|c|}
\hline & 1989 & 1990 & 1991 & 1992 \\
\hline $\begin{array}{c}\text { Political } \\
\text { Terrorscale }\end{array}$ & $2 / 2$ & $3 / 3$ & $3 / 3$ & $4 / 4$ \\
\hline Conflict Level & & $\begin{array}{l}\text { Violent political } \\
\text { conflict ( } 20 \text { deaths in } \\
\text { pro democracy } \\
\text { demonstrations) }\end{array}$ & $\begin{array}{l}\text { Violent political } \\
\text { conflict (tensions in } \\
\text { Rift Valley; Student } \\
\text { riots) }\end{array}$ & $\begin{array}{l}\text { Violent political } \\
\text { conflict; Low } \\
\text { intensity conflict } \\
\text { (ethnic violence in } \\
\text { Rift Valley: } 800 \\
\text { deaths) }\end{array}$ \\
\hline $\begin{array}{l}\text { Freedom } \\
\text { House }\end{array}$ & $6 / 6 / \mathrm{NF}$ & $6 / 6 / \mathrm{NF}$ & $6 / 6 / \mathrm{NF}$ & $4 / 5 / \mathrm{PF}$ \\
\hline $\begin{array}{c}\text { U.S. State } \\
\text { Department }^{1}\end{array}$ & $\begin{array}{c}(\mathrm{e})^{2}, \mathrm{P}^{3}, \mathrm{t}^{4}, \mathrm{CA}^{5}, \mathrm{CL}^{6}, \\
\mathrm{R}^{7}\end{array}$ & $(\mathrm{e})^{8}, \mathrm{t}^{9}, \mathrm{R}^{12} \mathrm{CA}^{10}, \mathrm{CL}^{11}$, & 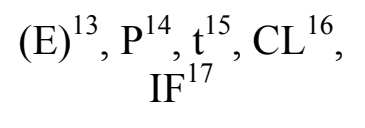 & $\begin{array}{l}\mathrm{e}^{18}, \mathrm{P}^{19}, \mathrm{t}, \mathrm{CA}^{20}, \\
\mathrm{CL}^{21}, \mathrm{IF}^{22}\end{array}$ \\
\hline $\begin{array}{c}\text { Amnesty } \\
\text { International }\end{array}$ & $\mathrm{T}^{23}, \mathrm{P}^{24}$ & ${ }^{25} \mathrm{t}^{26},(\mathrm{P})^{27}$ & $\mathrm{~T}$ & $\mathrm{~T}^{28}, \mathrm{P}^{29}$ \\
\hline
\end{tabular}




\begin{tabular}{|c|c|c|c|c|}
\hline & 1993 & 1994 & 1995 & 1996 \\
\hline $\begin{array}{c}\text { Political } \\
\text { Terrorscale }\end{array}$ & $3 / 4$ & $4 / 4$ & $4 / 3$ & $4 / 4$ \\
\hline Conflict Level & $\begin{array}{c}\text { Low intensity } \\
\text { conflict (Rift Valley) }\end{array}$ & $\begin{array}{l}\text { Violent political } \\
\text { conflict (Rift Valley; } \\
\text { Burnt Forest; } \\
\text { Mombasa, between } \\
\text { coastal groups and } \\
\text { Luos; Turkana) }\end{array}$ & $\begin{array}{c}\text { Violent political } \\
\text { conflict (Rift Valley; } \\
\text { Turkana; Maela; } \\
\text { Nairobi slums; FEM } \\
\text { guerrillas) }\end{array}$ & $\begin{array}{c}\text { Violent Political } \\
\text { conflict (Rift Valley; } \\
\text { Turkana) }\end{array}$ \\
\hline $\begin{array}{l}\text { Freedom } \\
\text { House }\end{array}$ & $5 / 6 / \mathrm{NF}$ & 6/6/NF & $7 / 6 / \mathrm{NF}$ & $7 / 6 / \mathrm{NF}$ \\
\hline $\begin{array}{c}\text { U.S. State } \\
\text { Department }\end{array}$ & $\begin{array}{l}\mathrm{e}^{30}, \mathrm{~T}^{31}, \mathrm{P}^{32}, \mathrm{CA}^{33}, \\
\mathrm{CL}^{34}, \mathrm{IF}^{35}\end{array}$ & $\begin{array}{l}\mathrm{e}^{36}, \mathrm{~T}, \mathrm{P}^{37}, \mathrm{~S}^{38}, \mathrm{CA}^{39} \\
\mathrm{CL}^{40}, \mathrm{FE} / \mathrm{R}^{41}\end{array}$ & $\begin{array}{c}\mathrm{e}^{42}, \mathrm{~T}, \mathrm{P}^{43}, \mathrm{~S}^{44}, \mathrm{CA}^{45} \\
\mathrm{CL}^{46}, \mathrm{FE} / \mathrm{R}^{47}\end{array}$ & $\begin{array}{c}\mathrm{E}, \mathrm{T}^{48}, \mathrm{P}^{49}, \mathrm{AE}^{50} \\
\mathrm{CA}^{51}, \mathrm{CL}^{52}, \mathrm{CP}^{53}, \mathrm{~S}^{54} \\
\mathrm{R}^{55}, \mathrm{IF}^{56}\end{array}$ \\
\hline
\end{tabular}

\begin{tabular}{|c|c|c|c|c|}
\hline & 1997 & 1998 & 1999 & 2000 \\
\hline $\begin{array}{c}\text { Political } \\
\text { Terrorscale }\end{array}$ & 4 & 3 & & 3 \\
\hline Conflict Level & $\begin{array}{c}\text { Low intensity } \\
\text { conflict (etnic } \\
\text { violence along coast: } \\
\text { at least } 100 \text { deaths); } \\
\text { Violent political } \\
\text { conflict (etnic } \\
\text { violence between } \\
\text { Pokots-Marakwets, } \\
\text { Turkanas-Samburus, } \\
\text { Maasais-Kisiis, and } \\
\text { violence in Isiolo, } \\
\text { Meru/Nyambene, } \\
\text { Garissa, and Kilgoris, } \\
\text { and violence from } \\
\text { ethiopian rebels) }\end{array}$ & $\begin{array}{c}\text { Low Intensity } \\
\text { conflict (rift Valley: } \\
\text { more than } 100 \\
\text { deaths; Pokots, } \\
\text { Marakwets, Maasai, } \\
\text { Turkanas, Kisiis) and } \\
\text { violent political } \\
\text { conflict (Mombasa; } \\
\text { Ethiopian incursions) }\end{array}$ & $\begin{array}{c}\text { Low Intensity } \\
\text { conflict (Rift Valley; } \\
\text { Moyale-Marsabit;) } \\
\text { and violent political } \\
\text { conflict } \\
\text { (Boranas/Somalis } \\
\text { Pokot, Marakwet, } \\
\text { Baringo: at least } 65 \\
\text { killed) }\end{array}$ & $\begin{array}{c}\text { Low Intensity } \\
\text { conflict and violent } \\
\text { political conflict; } \\
\text { in all ethnic violence } \\
\text { claimed an average } \\
\text { of } 75 / 100 \text { deaths per } \\
\text { month }\end{array}$ \\
\hline $\begin{array}{l}\text { Freedom } \\
\text { House }\end{array}$ & $6 / 6 / \mathrm{NF}$ & $6 / 5 / \mathrm{NF}$ & $6 / 5 / \mathrm{NF}$ & $6 / 5 / \mathrm{NF}$ \\
\hline $\begin{array}{c}\text { U.S. State } \\
\text { Department }\end{array}$ & $\begin{array}{c}\mathrm{E}, \mathrm{T}^{57}, \mathrm{P}^{58}, \mathrm{AE}^{59}, \\
\mathrm{CA}^{60}, \mathrm{CL} / \mathrm{FL}^{61}, \mathrm{CP}^{62}, \\
\mathrm{~S}^{63}, \mathrm{IF}^{64}\end{array}$ & $\begin{aligned} \mathrm{E}^{65}, \mathrm{~T}^{66}, \mathrm{P}^{67}, \mathrm{AE}^{68} \\
\mathrm{CA}^{69}, \\
\mathrm{CL} / \mathrm{FL}^{70}, \mathrm{CP}^{71}, \\
\mathrm{~S}^{72}, \mathrm{IF}^{73}\end{aligned}$ & $\begin{aligned} \mathrm{E}^{74}, \mathrm{~T}^{75}, \mathrm{P}^{76}, \mathrm{AE}^{77} \\
\mathrm{CA}^{78}, \mathrm{CL} / \mathrm{FL}^{79}, \mathrm{CP}^{80}, \\
\mathrm{~S}^{81}, \mathrm{IF}^{82}\end{aligned}$ & $\begin{array}{c}\mathrm{E}, \mathrm{T}^{83}, \mathrm{P}^{84}, \mathrm{AE}^{85}, \\
\mathrm{CA}^{86}, \mathrm{CL}^{\mathrm{CLL}}{ }^{87}, \mathrm{CP}^{88}, \\
\mathrm{~S}^{89}, \mathrm{IF}^{90}\end{array}$ \\
\hline
\end{tabular}




\begin{tabular}{|c|c|c|}
\hline & 2001 & 2002 \\
\hline \multicolumn{3}{|l|}{$\begin{array}{c}\text { Political } \\
\text { Terrorscale }\end{array}$} \\
\hline Conflict Level & $\begin{array}{c}\text { Low intensity } \\
\text { conflict (Rift Valley; } \\
\text { Kerio Valley: Pokots } \\
\text { vs. Marakwets vs. } \\
\text { Baringo; Moyale- } \\
\text { Marsabit, OLF); } \\
\text { Violent political } \\
\text { conflict (muslims vs. } \\
\text { slum dwellers; } \\
\text { Somali bandits); In } \\
\text { all ethnic violence } \\
\text { claimed an average } \\
\text { of } 50 / 75 \text { deaths per } \\
\text { month }\end{array}$ & $\begin{array}{c}\text { Low intensity } \\
\text { conflict (serious } \\
\text { ethnic conflicts); } \\
\text { violent political } \\
\text { conflict (mungiki; } \\
\text { various ethnic } \\
\text { conflicts that also } \\
\text { spilled over from and } \\
\text { to neighbouring } \\
\text { countries); In all } \\
\text { ethnic violence } \\
\text { claimed an average } \\
\text { of } 50 / 75 \text { deaths per } \\
\text { month }\end{array}$ \\
\hline $\begin{array}{c}\text { Freedom } \\
\text { House }\end{array}$ & $6 / 5 / \mathrm{NF}$ & $4 / 4 / \mathrm{PF}$ \\
\hline $\begin{array}{c}\text { U.S. State } \\
\text { Department }\end{array}$ & $\begin{aligned} \mathrm{E}, \mathrm{T}^{91}, \mathrm{P}^{92}, \mathrm{AE}^{93}, \\
\mathrm{CA}^{94}, \mathrm{CL}^{9} \mathrm{FL}^{95}, \mathrm{CP}^{96}, \\
\mathrm{~S}^{97}, \mathrm{IF}^{98}\end{aligned}$ & $\begin{array}{c}\mathrm{E}^{99}, \mathrm{P}^{100}, \mathrm{~T}^{101}, \mathrm{AE}^{102}, \\
\mathrm{CA}^{103}, \mathrm{CL} / \mathrm{FL}^{104}, \\
\mathrm{CP}^{105}, \mathrm{PC}^{106}, \mathrm{~S}^{107}, \\
\mathrm{IF}^{108}, \mathrm{R}^{109}\end{array}$ \\
\hline
\end{tabular}




\section{Working conditions:}

1989: Health and safety regulations are only applicable to work in factories, construction and the docks, and does not cover agriculture. However many rural workers are exposed to dangerous pesticides. The Government has vowed to expand the "Factories Act" to the agricultural sector. Inspections are inadequate. Although they have the power to make surprise visits they rarely do. The "Factories Act" does not contain provisions that protect the worker who files complaints.

1990: The "Factories Act" was amended to include the "non-industrial sector". Inspections are inadequate. Although they have the power to make surprise visits they rarely do. Inspectors usually only inspect after a complaint. The "Factories Act" does not contain provisions that protect the worker who files complaints.

1991: Inspectors are now vested with the right to issue notices "enjoining employers from practices or activities which involve a risk of serious personal injuries." Workers that lodge a complaint are not protected by law. The government exempted enterprises in the export processing zones from the occupational health and safety requirements of the Factories Act. There were between 2000 and 3000 inspections.

1992: Inspectors are now vested with the right to issue notices "enjoining employers from practices or activities which involve a risk of serious personal injuries." Workers that lodge a complaint are not protected by law. The government exempted enterprises in the export processing zones from the occupational health and safety requirements of the Factories Act. There were between 2000 and 3000 inspections.

1993: A s a result of an amendment in 1990 inspections have the power to issue notices enjoining employers from practices or activities which involve a risk of serious personal injuries.' Inspections increased from 3,000 in 1992 to 16,132 in 1993.

1994: There are 65 health and safety inspectors attached to the Ministry of Labour's Directorate of Occupational Health and Safety Services. They inspect factories and work sites and have the power to 'issue notices enjoining employers from practices or activities which involve a risk of serious personal injuries.' The inspections maintained their level, which had increased dramatically in 1993. There was a slight decline in work related accidents and illnesses.

1995: Inspections continued at a high level.

1996: Inspections remained at a high level. Though workers are not forced by law to remain in hazardous working conditions, many would do so because of the high unemployment problem.

1997: Inspections remained at a high level. Though workers are not forced by law to remain in hazardous working conditions, many would do so because of the high unemployment problem.

1998: Inspections remained at a high level. As a result of a new amendment, factories of over 20 employees must have a health and safety committee with worker's representation. However only a quarter of the country's very largest factories had such a committee by years' end. Though workers are not forced by law to remain in hazardous working conditions, many would do so because of the high unemployment problem.

1999: Inspections remained at a high level. As a result of a new amendment, factories of over 20 employees must have a health and safety committee with worker's representation. However less than half of the country's very largest factories had such a committee by years' end. Though workers are not forced by law to remain in hazardous working conditions, many would do so because of the high unemployment problem.

2000: Inspections remained at a high level. As a result of a new amendment, factories of over 20 employees must have a health and safety committee with worker's representation. However less than half of the country's very largest factories had such a committee by years' end. Though workers are not forced by law to remain in hazardous working conditions, many would do so because of the high unemployment problem.

2001: Inspectors have no authority to inspect factories in the EPZ's. Labour and NGO's criticized health and safety conditions in the EPZ's. Inspections remained at a high level. As a result of a new amendment, factories of over 20 employees must have a health and safety committee with worker's representation. However less than half of the country's very largest factories had such a committee by years' end. Though workers are not forced by law to remain 
in hazardous working conditions, many would do so because of the high unemployment problem.

2002: Inspectors have no authority to inspect factories in the EPZ's. Labour and NGO's criticized health and safety conditions in the EPZ's. The government undertook steps to revoke the exception. Conditions in the EPZ's were illustrated by conditions in the cut flower industry. There were numerous violations worker rights in that industry, including "use of hazardous pesticides and fertilizers without adequate protection, low wages and casualization (hiring long term "seasonal workers" without proving any benefits or job security)". As a result of a new amendment, factories of over 20 employees must have a health and safety committee with worker's representation. However less than half of the country's very largest factories had such a committee by years' end. Though workers are not forced by law to remain in hazardous working conditions, many would do so because of the high unemployment problem.

\section{Brief historical/political overview:}

\section{AMENSTY INTERNATIONAL:}

1990: Many people who criticised the Government were detained or harassed. Many were prodemocracy advocates and human rights activists. The ruling KANU did not want to let go of the one-party system, though it did propose to reform the party itself, the electoral system, the protection of judges and Public Prosecutors.

1991: Multiparty democracy reintroduced. Change in constitution allows more political parties. The change was forced by donors who threatened to postpone aid for six months until democratic rights and human rights ameliorated. However President Daniel Arap Moi continued to control 'a governing system in which power is centred in the office of the President and the President's party, the former single party, the Kenya African National Union (KANU).

1992: Elections, considered 'controversial' (violence intimidation, fraud, and other irregularities). But it brought about a modest strengthening of democratic institutions.

\section{STATE DEPARTMENT:}

1989: World coffee prices decline and lead to payment problems. Many were unemployed.

1990: The tourist sector suffers serious losses due to riots in 1990 and subsequent political tension. Unemployment continues to be a growing major problem. The demand for a multiparty system leads to serious rioting from July 7 until July 11 in Nairobi. Leaving 20 dead, more than 70 injured and over 1000 arrested. The Government set minor steps towards political change. Electoral laws are changed (minor changes).

1991: President Daniel T. Arap Moi recommends that Kenya adopt legislation to pave the way to a multiparty system. The legislation is passed on December 10. Tourism grows a little less due to the Gulf War. Unemployment is serious and growing. Several politicians in the Rift Valley attended a rally purported to "ban" members of the FORD from entering the Valley. "They threatened reprisals against members of the Kikuyu ethnic group and multiparty supporters settled in the region".

1992: Elections are held on December 29. However "the conduct of these elections left unclear the ability of the Kenyan people to change their government by democratic means." Moreover the President continues to control the governing system. Government assisted violence directed at political opponents and certain ethnic groups caused hundreds of casualties and thousands of displaced people. The Government used assets of State including the judiciary, to clamp down on dissent. In 1992 without any rebuke from the President KANU politicians continued to heighten tribal tension in the Rift Valley. In several regions "tribal" clashes resulted in 800 deaths and thousands of homeless people.

1993: KANU holds a majority in Parliament, but no two-thirds majority which is required to pass constitutional amendments. The party applies great pressure (bribes and blackmail) to entice or coerce opposition MP's to defect to KANU. After 2 years the Government finally took some action 'to curb ethnic violence centred in the Rift Valley'. The Government still has to get used to multi party politics. There were a serious setbacks 'in the Government's commitment to human rights, ethnic and political tolerance, and the rule of law'.

1994: The Government took some steps to improve its human rights practices. 
1995: Human rights situation worsened in 1995. On children's rights, the Government proposes new legislation to establish a National Council of Children's services 'to supervise the planning and financing of child welfare activities'. However the legislation does not mention homelessness, female circumcision, forced labour, sexual abuse, and education.

1996: Human rights situation showed some signs of improvement. The Government established a standing committee on human rights and started a dialogue with human rights organisations. Legislation on children's rights was still not passed. A motion to outlaw Genital mutilation was defeated.

1997: President Daniel Arap Moi was re-elected in December. The elections were imperfect, but generally reflected the 'popular will'. In the first eight months of the year the human rights situation deteriorated. In the last four months of the year the situation improved significantly. The improvement was due to the brokering by bipartisan Interparty Parliamentary Group (IPPG) of a package of wide ranging political reforms, paving the way to the December elections. Ethnic violence along the coast in August and September caused major setbacks in tourism and foreign investment.

1998: Human rights record remained poor, although there were some improvements in some areas. In August a car bomb exploded at the U.S. Embassy in Nairobi killing more than 200 people and injuring thousands.

1999: Human rights record remained poor. Some improvements in some areas, but worsening in other areas.

2001: June, 4 members (amongst which the leader) of the National Development Party are appointed to the Cabinet. KANU and NDP have forged an alliance and are contemplating a merger.

2002: On December 27, Mwai Kibaki of the opposition NARC party (a coalition of more than a dozen parties) won the Presidential elections. Former President Arap Moi stepped down on December 30. There were five candidates for the presidency, Arap Moi did not stand again, because constitutionally he was not allowed to go for another term. The ruling KANU party also lost the parliamentary elections, and consequently lost its majority in parliament, a majority now held by NARC. There were violent incidents in the pre-election period and on election day. Overall the elections were peaceful and observers concluded they generally reflected the popular will and were free and fair. The Government (of Arap Moi) continued to discriminate publicly against ethnic groups, leading to violence, and causing a number of deaths.

\footnotetext{
${ }^{1}$ Following a directive by Secretary of State Warren Christopher some changes in reporting were made as of the 1993 report. The changes include a stronger emphasis on prison conditions and a new section on "discrimination based on race, sex, religion, disability, language or social status. This new section also includes a paragraph on discrimination against children.

${ }^{2}$ There were a number of deaths in prison under suspicious circumstances.

${ }^{3}$ Detainees and prisoners complain of poor food, beating, corruption, and inadequate facilities and medical care. The spread of meningitis is a serious problem. At least 32 prisoners died of meningitis during the year.

${ }^{4}$ It is unclear how many cases of torture there were. The number of allegations declined, but torture and police brutality remained "an important issue".

${ }^{5}$ Female circumcision is still practiced.

${ }^{6}$ Child labour in the formal sector is not a widespread problem. However many children work in the agricultural sector. They do not fall under the minimum age legislation.

${ }^{7}$ Refugees were denied permanent resettlement.

${ }^{8}$ At least one death in custody. The Foreign Minister died in "mysterious" circumstances. In clashes with police 20 demonstrators died. It is unclear what the exact circumstances of these deaths were.

${ }^{9}$ Prisoners were frequently beaten and otherwise abused. A number of cases of torture are described.

${ }^{10}$ Female circumcision is still practiced.

${ }^{11}$ Child labour in the formal sector is not a widespread problem. However many children work in the agricultural sector. They do not fall under the minimum age legislation.

${ }^{12}$ Some 12,000 refugees were refused permanent resettlement.

${ }^{13}$ One student was shot in the head during rioting. 37 Somali refugees drowned after allegedly being forcibly expelled from Kenya. Kenyan Navy towed two unseaworthy boats into rough water. There they capsized. The Navy has been accused of gross negligence. The Ministry of Home Affairs exonerated the Navy.

${ }^{14}$ There is overcrowding and insufficient funding for prison operations. Corruption and sexual abuse occur. Food and medical supplies are inadequate.

${ }^{15}$ Prisoners were frequently beaten and otherwise abused. A number of cases of torture are described.
} 
${ }^{16}$ Child labour in the formal sector is not a widespread problem. However many children work in the agricultural sector. They do not fall under the minimum age legislation.

${ }^{17}$ Malnutrition affects many nursing and pregnant women in prison.

${ }^{18}$ Tribal clashes caused 800 deaths. The clashes were provoked by government officials. Reports state that "Fighters" used to terrorize certain groups were transported in government vehicles and financed by the government. One person died in custody allegedly beaten to death. At least 6 unarmed demonstrators died through use of excessive force by the police. At least 500 people died in mob violence. The conduct of the security forces was mixed, some helped the victim, others turned a blind eye.

${ }^{19}$ Food and health care were inadequate. Bedding is in short supply and toilet facilities are inadequate. Sexual abuse is common.

${ }^{20}$ Female Genital Mutilation is still practiced. Rape is considered a serious problem in Kenyan schools.

${ }^{21}$ Child labour in the formal sector is not a widespread problem. However many children work in the agricultural sector. They do not fall under the minimum age legislation.

${ }_{22}$ Prisoners, especially nursing women with their infants, did not get adequate food.

${ }^{23}$ Especially of political prisoners. Secret or illegal detention facilitated the use torture.

${ }^{24}$ A.I. only mentions prison conditions for political detainees. These conditions were harsh. There was extensive use of solitary confinement and prisoners were permitted to leave their cells only one hour per day. 'Medical treatment and hygiene were poor and access to reading material was limited. Visits and correspondence from relatives were also severely restricted.'

${ }^{25}$ There is a report entitled: "Kenya: Silencing Opposition to One-Party Rule".

${ }^{26}$ Some political prisoners were tortured.

${ }^{27}$ One political prisoner accused the government of placing him in a prison where conditions amounted to 'inhuman and degrading treatment'. Notably he said the cells were under water.

${ }^{28}$ Amongst other methods, women were raped during questioning.

${ }^{29}$ Conditions were especially bad in Kamiti-prison in Nairobi and the prison for female prisoners Langata in Nairobi.

${ }^{30}$ There was one clear extrajudicial killing. Some deaths in prison could be related to beatings or use of excessive force. There is evidence that high ranking officials instigate and promote ethnic clashes which claimed over 1,000 lives. Mob violence cannot be directly attributed to the Government, but they can be held responsible for the fact they have not made it a priority. Mob violence claimed 508 lives.

${ }^{31}$ Other than the use of torture, political opposition are often the target of police brutality, and abuse.

${ }^{32}$ Conditions are life threatening. The Government does not have the will to curb the problem. There was no adequate food, and healthcare. There was a lack of quality food and bedding materials, and cells were often flooded and unheated. Sexual abuse is a problem. 977 prisoners died in the previous three years.

${ }^{33}$ Female genital mutilation continues to be widespread.

${ }^{34}$ Children often work as domestics in private homes, in the informal sector, and in family businesses and farms. Child employment in the formal wage sector is not a significant problem.

${ }^{35}$ A lack of (quality) food in prisons.

${ }^{36}$ There were a few cases in which police used excessive lethal force, at least one person dies in police custody as a result of a beating.

${ }^{37}$ Conditions are life threatening. There is sexual abuse (male and female), severe overcrowding, a poor diet, inadequate health care, substandard bedding materials, and flooded or unheated cells. Several hundreds died in prison.

${ }^{38}$ Many homeless streetchildren, because of 'economic displacement, a high population growth rate, and the ethnic clashes. There are tens of thousands streetchildren and the rate is growing by $10 \%$ annually.

${ }^{39}$ Streetchildren suffer from inhumane treatment by police. Female genital mutilation is still widespread.

${ }^{40}$ Children often work as domestics in private homes, in the informal sector, and in family businesses and farms. Child employment in the formal wage sector is not a significant problem.

${ }^{41}$ People wanting to return to the Rift Valley after the Government's establishment of security zones and the resulting decrease in violence, were prevented from resettling and forcibly removed by the Government.

${ }^{42}$ The number of extrajudicial killings is not reported. It is clear however from the report that there were extrajudicial executions.

${ }^{43}$ Conditions are life threatening. Sexual abuse continued to be a serious problem. And there was inadequate water, severe overcrowding, a poor diet, inadequate health care, substandard bedding materials, and flooded or unheated cells. More than hundred people died in prison.

${ }^{44}$ Many homeless streetchildren, because of 'economic displacement, a high population growth rate, and the ethnic clashes. There are tens of thousands streetchildren and the rate is growing by $10 \%$ annually.

${ }^{45}$ Streetchildren suffer from inhumane treatment by police. Female genital mutilation is still widespread. Child rape and molestation is increasingly becoming a problem.

${ }^{46}$ Children often work as domestics in private homes, in the informal sector, and in family businesses and farms. Child employment in the formal wage sector is not a significant problem.

${ }^{47}$ Displaced persons in the Rift Valley were again forcibly removed and prevented from returning to their homes.

${ }^{48}$ KHRC (Kenyan Human Rights Commission), an NGO, reported 90 cases of torture, including 17 deaths in the first nine months of 1996.

${ }^{49}$ Prisons at times are life-threatening. There was severe overcrowding, deficient health care, poor diet, inadequate water, and substandard bedding. Rape and AIDS are growing problems in prisons. A judge called the prisons "Death chambers". The Home Affairs minister reported that 814 prisoners had died of disease in the first nine months of 1995. Independent monitoring of prisons is not permitted. 
${ }^{50}$ Education is compulsory up to grade 12, but since free education has given way for a 'cost sharing' system, education has become too expensive for many Kenyans. There is also a great shortage in schools.

${ }^{51}$ Streetchildren suffer from inhumane treatment by police. Female genital mutilation is still widespread. Child rape and molestation is increasingly becoming a problem.

${ }^{52}$ Children often work as domestics in private homes, in the informal sector, and in family businesses and farms. Child employment in the formal wage sector is not a significant problem.

${ }^{53}$ Child prostitution has emerged as a major problem. It is often connected with the tourist trade.

${ }^{54}$ Many homeless streetchildren, because of 'economic displacement, a high population growth rate, and the ethnic clashes. There was an increase in the number of street children from 33,000 in 1990 to 44,000 in 1996.

${ }^{55}$ People displaced because of ethnic clashes did not return home (despite the Government's attempts to forcibly relocate them). There still was a great sense of insecurity.

${ }_{57}^{56}$ Moreover a drought, followed by floods, kept upward pressure on food prices.

${ }^{57}$ Torture of pre-trial detainees and prisoners occurred. In February Kenya acceded to the Convention against Torture. The KHRC reported at least 55 cases of torture, 12 resulted in deaths.

${ }^{58}$ Prisons often are life-threatening. There was severe overcrowding, deficient health care, poor diet, inadequate water, and substandard bedding. 631 prisoners died 'in jails during the year, due chiefly to anaemia, heart attack, malaria, typhoid fever, dysentery, tuberculosis, and AIDS. Rape of male and female inmates is a serious problem. No independent monitoring of prison conditions is permitted (also see 'childabuse').

${ }^{59}$ Education is compulsory up to grade 12 , but since free education has given way for a 'cost sharing' system, education has become too expensive for many Kenyans. There is also a great shortage in schools.

${ }^{60}$ Child rape is a grave problem. Female genital mutilation is widespread. According to a Human Rights Watch report, street children 'face harassment as well as physical and sexual abuse from the police and within the juvenile justice system simply because they are poor and homeless. They are held in deplorable conditions in crowded police station cells, often without toilets or bedding, with little food, and inadequate supplies. They are often incarcerated with adults and frequently beaten by police.'

${ }^{61}$ Children often work as domestics in private homes, in the informal sector, and in family businesses and farms. Child employment in the formal wage sector is not a significant problem. There were some instances of children being loaned out to pay off debts.

${ }^{62}$ Child prostitution is a growing and major problem. It is often connected to the tourist trade.

${ }^{63}$ There are 45,000 streetchildren (also see 'childabuse'). Many homeless streetchildren, because of 'economic displacement, a high population growth rate, and the ethnic clashes.

${ }^{64} \mathrm{~A}$ drought, followed by floods, kept upward pressure on food prices.

${ }^{65}$ There was an increased number of extrajudicial executions.

${ }^{66}$ Torture is used as an interrogation technique and as punishment, for both pre-trial detainees as convicted prisoners. KHRC reported 98 cases during the year. 10 cases resulted in death.

${ }^{67}$ Prisons often are life-threatening. There was severe overcrowding, deficient health care, poor diet, inadequate water, and substandard bedding. 536 prisoners died 'in jails during the year, due chiefly to anaemia, heart attack, malaria, typhoid fever, dysentery, tuberculosis, and AIDS. Rape of male and female inmates is a serious problem. No independent monitoring of prison conditions is permitted.

${ }^{68}$ Education is compulsory up to grade 12, but since free education has given way for a 'cost sharing' system, education has become too expensive for many Kenyans. There is also a great shortage in schools. Four million children between 6 and 14 or out of school.

${ }^{69}$ Child rape is a grave problem. Female genital mutilation is widespread. According to a Human Rights Watch report, street children 'face harassment as well as physical and sexual abuse from the police and within the juvenile justice system simply because they are poor and homeless. They are held in deplorable conditions in crowded police station cells, often without toilets or bedding, with little food, and inadequate supplies. They are often incarcerated with adults and frequently beaten by police.'

${ }^{70}$ Children often work as domestics in private homes, in the informal sector, and in family businesses and farms. Children working in the informal sector is difficult to control, but the problem is significant (also see "child prostitution'). Child employment in the formal wage sector is not a significant problem. There are some cases in rural areas of children being loaned as workers to pay off debts.

${ }^{71}$ Child prostitution is a growing and major problem. It is often connected to the tourist trade.

${ }^{72}$ There are about 50,000 streetchildren. Many homeless streetchildren, because of 'economic displacement, a high population growth rate, and the ethnic clashes. (also see 'childabuse')

${ }_{74}^{73}$ A drought, followed by floods, kept upward pressure on food prices.

${ }_{75}^{74}$ Increased number of extrajudicial killings.

${ }^{75}$ In the first nine months 24 cases of torture resulted in death.

${ }^{76}$ Prisons often are life-threatening. There was severe overcrowding, deficient health care, poor diet, inadequate water, and substandard bedding. 196 prisoners died in prisons during the first 9 months of the year, 'due chiefly to anaemia, heart attack, malaria, typhoid fever, dysentery, tuberculosis, and AIDS'. Rape of male and female inmates is a serious problem. No independent monitoring of prison conditions is permitted.

${ }^{77}$ Education is compulsory up to grade 12, but since free education has given way for a 'cost sharing' system, education has become too expensive for many Kenyans. There is also a great shortage in schools. Four million children between 6 and 14 or out of school.

${ }^{78}$ A human Rights Watch Report released in September highlighted the problem of corporal punishment in Kenya, resulting in excessive caning and abuse of pupils by teachers. There were reports of children being killed for body parts to be used by people practicing healing rituals. Child rape is a grave problem. Female genital mutilation is widespread. According to a Human Rights Watch report, street children 'face harassment as well as physical and 
sexual abuse from the police and within the juvenile justice system simply because they are poor and homeless. They are held in deplorable conditions in crowded police station cells, often without toilets or bedding, with little food, and inadequate supplies. They are often incarcerated with adults and frequently beaten by police.'

${ }^{79}$ Children often work as domestics in private homes, in the informal sector, and in family businesses and farms. Children working in the informal sector is difficult to control, but the problem is significant (also see "child prostitution'). Child employment in the formal wage sector is not a significant problem. There are some cases in rural areas of children being loaned as workers to pay off debts.

${ }^{80}$ Child prostitution is a growing and major problem. It is often connected to the tourist trade. The problem is growing due to the spread of HIV/AIDS which makes many orphans.

${ }^{81}$ There are about 50,000 streetchildren. Many homeless streetchildren, because of 'economic displacement, a high population growth rate, and the ethnic clashes. (also see 'childabuse').

${ }^{82}$ Drought and famine in some rural areas.

${ }^{83}$ In the first nine months 49 cases of torture resulted in death.

${ }^{84}$ Prisons often are life-threatening. There was severe overcrowding, deficient health care, poor diet, inadequate water, and substandard bedding. 658 prisoners died in prisons during the first 10 months of the year, "due chiefly to anaemia, heart attack, malaria, typhoid fever, dysentery, tuberculosis, and AIDS'. Rape of male and female inmates is a serious problem. No independent monitoring of prison conditions is permitted. However senior public officials, such as the Attorney General and a District Commissioner have criticised prison conditions. Courts are primarily responsible for overcrowding, because of the backlog of cases.

${ }^{85}$ Education is compulsory up to grade 12, but since free education has given way for a 'cost sharing' system, education has become too expensive for many Kenyans. There is also a great shortage in schools. Four million children between 6 and 14 or out of school.

${ }^{86}$ There was a problem of corporal punishment in schools. There were reports of children being killed for body parts to be used by people practicing healing rituals. Child rape and child molestation (also by teachers) is a grave and growing problem. Female genital mutilation is declining. Efforts by the Government and certain tribes, as well as NGO and press attention have led to a sharp decline. In December 169 girls suffered FGM, compared to 12,000 girls during the same month in the previous four years. According to a Human Rights Watch report, street children 'face harassment as well as physical and sexual abuse from the police and within the juvenile justice system simply because they are poor and homeless. They are held in deplorable conditions in crowded police station cells, often without toilets or bedding, with little food, and inadequate supplies. They are often incarcerated with adults and frequently beaten by police.'

${ }^{87}$ Children often work as domestics in private homes, in the informal sector, and in family businesses and farms. Children working in the informal sector is difficult to control, but the problem is significant (also see 'child prostitution'). Child employment in the formal wage sector is not a significant problem. There are some cases in rural areas of children being loaned as workers to pay off debts. By the end of the year parliament had not ratified ILO Convention 182.

${ }^{88}$ Child prostitution is a growing and major problem. It is often connected to the tourist trade. The problem is growing due to the spread of HIV/AIDS which makes many orphans

89 There are about 60,000 streetchildren. Many homeless streetchildren, because of 'economic displacement, a high population growth rate, and the ethnic clashes. (also see 'childabuse').

${ }_{90}$ Drought and famine in some rural areas. Food shortage in some prisons (while generally prisoners receive three meals, some guards would appropriate meat).

${ }^{91}$ KHRC reported 49 deaths through torture. Another NGO (People Against Torture) reported 70 cases and was still documenting cases by year's end.

${ }_{92}$ Prison conditions are harsh and life threatening. There was severe overcrowding, deficient health care, poor diet, inadequate water, and substandard bedding. 464 prisoners died in prisons during the first 10 months of the year, 'due chiefly to anaemia, heart attack, malaria, typhoid fever, dysentery, tuberculosis, and AIDS'. Rape of male and female inmates is a serious problem. No consistent independent monitoring of prison conditions is permitted. However some NGO's have started working with the Government in evaluating torture cases, performing autopsies and inspecting prisons. However senior public officials, such as the Attorney General and a District Commissioner have criticised prison conditions. Courts are primarily responsible for overcrowding, because of the backlog of cases.

${ }_{93}$ Education is compulsory up to grade 12, but since free education has given way for a 'cost sharing' system, education has become too expensive for many Kenyans. There is also a great shortage in schools. Four million children between 6 and 14 or out of school.

${ }^{94}$ Child rape and child molestation (also by teachers) is a grave and growing problem. Female genital mutilation is declining. Efforts by the Government and certain tribes, as well as NGO and press attention have led to a sharp decline. According to a Human Rights Watch report, street children 'face harassment as well as physical and sexual abuse from the police and within the juvenile justice system simply because they are poor and homeless. They are held in deplorable conditions in crowded police station cells, often without toilets or bedding, with little food, and inadequate supplies. They are often incarcerated with adults and frequently beaten by police.'

${ }^{95}$ Children often work as domestics in private homes, in the informal sector, and in family businesses and farms. Children working in the informal sector is difficult to control, but the problem is significant (also see "child prostitution'). Child employment in the formal wage sector is not a significant problem. According to a survey, there are 1.9 million children working, of whom 1.4 million work full time and 500,000 work while attending school. However the number of children working might be as high as 5 million. There are some cases in rural areas of children being loaned as workers to pay off debts. By the end of the year parliament had not ratified ILO Convention 182. 
${ }^{96}$ Child prostitution is a growing and major problem. It is often connected to the tourist trade. The problem is growing due to the spread of HIV/AIDS which makes many orphans.

${ }^{97}$ There are more than 60,000 streetchildren. Many homeless streetchildren, because of 'economic displacement, a high population growth rate, and the ethnic clashes. (also see 'childabuse').

${ }_{98}^{98}$ Drought and famine in some rural areas.

${ }^{99}$ According to the Kenya Human Rights Commission (KHRC) police committed more than a thousand extrajudicial executions in the last decade. This year police killed 117 suspected criminals, and another 11 suspects and detainees died while in police custody. Bystanders in shootouts with criminals also died. Persons died from torture while in custody.

${ }^{100}$ Prison conditions were harsh and life threatening. There was severe overcrowding, deficient health care, inadequate water, diet and bedding. There were frequent instances of torture and abuse. Rape (primarily by fellow inmates) of male and female prisoners was a serious problem. Incidence of HIV/AIDS was increasing. Prisoners were detained in unsanitary conditions, and did not have adequate access to health care, thus making the spread of disease easier. As a consequence disease was widespread and the death rate was high. According to the government 536 prisoners died in prisons, 'due chiefly to anaemia, heart attack, malaria, typhoid fever, dysentery, tuberculosis, and AIDS'.

${ }^{101}$ The problem is widespread. There were hundreds of cases during the year. KHRC reported 49 torture-related deaths in 2001. People Against Torture (PAT) reported 70 torture related deaths and a total of 238 cases of torture in 2001 .

${ }^{102}$ Education is compulsory up to grade 12 , but since free education has given way for a 'cost sharing' system, education has become too expensive for many Kenyans. There is also a great shortage in schools. Four million children between 6 and 14 or out of school. According to the Minister of Home Affairs, "Three million children who should e in school were not and 8.6 million more do not have access to basic needs".

${ }^{103}$ FGM was widespread and in contrast with earlier figures is the number of FGM performed is not dramatically declining. Corporal punishment in schools was formally banned, but did not cease completely. Child rape is a serious problem. Street children 'face harassment as well as physical and sexual abuse from the police and within the juvenile justice system simply because they are poor and homeless. They are held in deplorable conditions in crowded police station cells, often without toilets or bedding, with little food, and inadequate supplies. They are often incarcerated with adults and frequently beaten by police.'

${ }^{104}$ Children often work as domestics in private homes, in the informal sector, and in family businesses and farms. Children working in the informal sector is difficult to control and increasing due to economic hardship and the spread of HIV/AIDS, in any case the problem is significant (also see 'child prostitution'). Child employment in the formal wage sector is not a significant problem. According to a survey, there are 1.9 million children working, of whom 1.3 million work full time and 600,000 work while attending school. However the number of children working might be as high as 5 million. There are some cases in rural areas of children being loaned as workers to pay off debts. In cooperation with the ILO and NGO's the Kenyan government has set up schemes to sensitise employers and return children back to school.

${ }^{105}$ Child prostitution is a growing and major problem. It is often connected to the tourist trade. The problem is growing due to the spread of HIV/AIDS which makes many orphans. The ILO reported there were 30,000 girls under the age of 19 working as a prostitute.

${ }^{106}$ Juveniles were often kept with adults. Juvenile detention centres were understaffed, there was minimal social and exercise time. All detention centres were severely overcrowded. Accommodation, food and medical care were inadequate. There was no separation between the majority of children arrested on the streets "as victims of neglect or children in need of care and discipline", and the more serious offenders. No consistent independent monitoring of prison conditions is permitted. However some NGO's have started working with the Government in evaluating torture cases, performing autopsies and inspecting prisons. Courts are primarily responsible for overcrowding, because of the backlog of cases.

${ }^{107}$ There were an estimated 60,000 street children in Nairobi in 2000. A newspaper reported that there were a total of 250,000 (a conservative estimate) street children in urban areas in Kenya.

${ }^{108}$ Overcrowding in prisons led to food and water shortages. The food and water that was present was qualitively inadequate.

${ }^{109}$ Because of fear for renewed violence many displaced persons have not returned to the Rift Valley. 


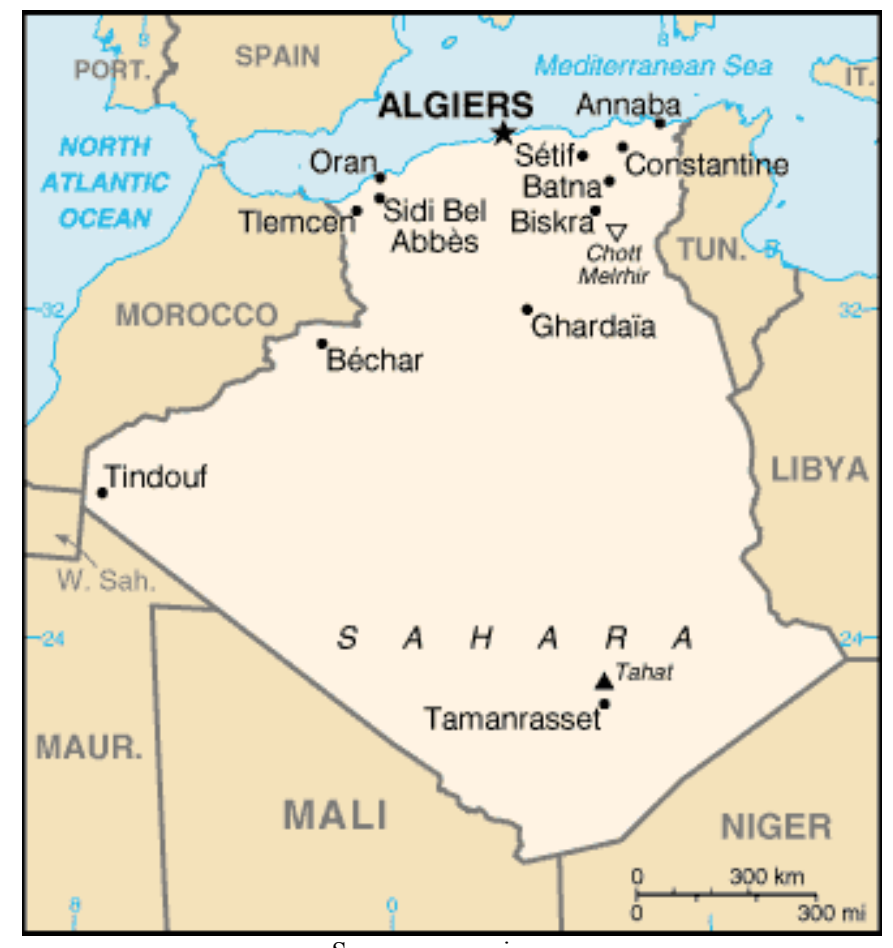

ALGERIA

(population: $32,818,500$ )

\begin{tabular}{|c|c|c|c|c|}
\hline & 1989 & 1990 & 1991 & 1992 \\
\hline $\begin{array}{c}\text { Political } \\
\text { Terrorscale }\end{array}$ & $2 / 2$ & $2 / 2$ & $3 / 3$ & $4 / 4$ \\
\hline Conflict Level & & & $\begin{array}{l}\text { low-intensity } \\
\text { confllict (300 killed } \\
\text { during rioting) }\end{array}$ & $\begin{array}{c}\text { Low-intensity } \\
\text { conflict ( } 70 \text { killed in } \\
\text { rioting, more than } \\
200 \text { killed in terrorist } \\
\text { attacks) }\end{array}$ \\
\hline $\begin{array}{c}\text { Freedom } \\
\text { House }\end{array}$ & $6 / 4 / \mathrm{PF}$ & $4 / 4 / \mathrm{PF}$ & $4 / 4 / \mathrm{PF}$ & $7 / 6 / \mathrm{NF}$ \\
\hline $\begin{array}{c}\text { U.S. State } \\
\text { Department }^{1}\end{array}$ & $\mathrm{CL}^{2}$ & $\mathrm{t}^{3}, \mathrm{CL}^{4}$ & $\mathrm{t}, \mathrm{CL}^{5}$ & $(E)^{6}, t^{7}, C^{8}$ \\
\hline & 1993 & 1994 & 1995 & 1996 \\
\hline $\begin{array}{c}\text { Political } \\
\text { Terrorscale }\end{array}$ & $4 / 5$ & $5 / 5$ & $5 / 5$ & $5 / 5$ \\
\hline
\end{tabular}




\begin{tabular}{|c|c|c|c|c|}
\hline Conflict Level & $\begin{array}{c}\text { High intensity } \\
\text { conflict ( } 500 \\
\text { terrorists killed, } 300 \\
\text { security forces, and } \\
\text { an unknown number } \\
\text { of civilians) }\end{array}$ & $\begin{array}{l}\text { High intensity } \\
\text { conflict (security } \\
\text { forces killed } \\
\text { hundreds of } \\
\text { 'terrorists', terrorist } \\
\text { groups killed } \\
\text { hundreds, including } \\
\text { security forces, } \\
\text { civilians, journalists, } \\
\text { lawyers and } \\
\text { foreigners) }\end{array}$ & $\begin{array}{l}\text { High intensity } \\
\text { conflict (including } \\
\text { deaths of civilians } \\
\text { and terrorists by } \\
\text { security forces; } \\
\text { deaths in targeted } \\
\text { killings as well as } \\
\text { indiscriminate attacks } \\
\text { on security forces } \\
\text { and civilians by } \\
\text { Islamist groups } \\
\text { resulting in perhaps } \\
\text { 'thousands of } \\
\text { deaths'. }\end{array}$ & $\begin{array}{l}\text { High Intensity } \\
\text { conflict (hundreds } \\
\text { killed in terrorist } \\
\text { bombings) and } \\
\text { violent political } \\
\text { conflict (Kabilye) }\end{array}$ \\
\hline $\begin{array}{l}\text { Freedom } \\
\text { House }\end{array}$ & $7 / 6 / \mathrm{NF}$ & $7 / 7 / \mathrm{NF}$ & 6/6/NF & 6/6/NF \\
\hline $\begin{array}{c}\text { U.S. State } \\
\text { Department }\end{array}$ & $\mathrm{E}^{9}, \mathrm{~T}^{10}, \mathrm{CA}^{11}, \mathrm{CL}^{12}$ & $\mathrm{E}^{13}, \mathrm{~T}^{14}, \mathrm{CA}^{15}, \mathrm{CL}^{16}$ & $\mathrm{E}^{17}, \mathrm{~T}^{18}, \mathrm{pL}^{19}, \mathrm{CA}^{20}$ & $\mathrm{E}^{22}, \mathrm{~T}^{23}, \mathrm{p}^{24}, \mathrm{CA}^{26}$, \\
\hline
\end{tabular}

\begin{tabular}{|c|c|c|c|c|}
\hline $\begin{array}{c}\text { Political } \\
\text { Terrorscale }\end{array}$ & $\mathbf{1 9 9 7}$ & $\mathbf{1 9 9 8}$ & $\mathbf{1 9 9 9}$ & $\mathbf{2 0 0 0}$ \\
\hline Conflict Level & $\begin{array}{c}\text { High Intensity (6,000 } \\
\text { to } 7,000 \text { killed) and } \\
\text { low intensity conflict } \\
\text { (Kabilye) }\end{array}$ & $\begin{array}{c}\text { High intensity }(7,000 \\
\text { killed) and low } \\
\text { intensity conflict } \\
\text { (Kabilye) }\end{array}$ & $\begin{array}{c}\text { High Intensity }(3,000 \\
\text { killed) and low } \\
\text { intensity conflict } \\
\text { (Kabilye) }\end{array}$ & $\begin{array}{c}\text { High Intensity }(2,500 \\
\text { killed) and low } \\
\text { intensity conflict } \\
\text { (Kabilye) }\end{array}$ \\
\hline $\begin{array}{c}\text { Freedom } \\
\text { House }\end{array}$ & $6 / 6 / \mathrm{NF}$ & $6 / 5 / \mathrm{NF}$ & $6 / 5 / \mathrm{NF}$ & $6 / 5 / \mathrm{NF}$ \\
\hline $\begin{array}{c}\text { U.S. State } \\
\text { Department }\end{array}$ & $\mathrm{E}^{27}, \mathrm{~T}, \mathrm{p}^{28}, \mathrm{CA}^{29}$, & $\mathrm{E}^{31}, \mathrm{~T}, \mathrm{p}^{32}, \mathrm{CA}^{33}$, & $\mathrm{E}^{35}, \mathrm{t}^{36}, \mathrm{p}^{37}, \mathrm{IF}^{38}$, & $\mathrm{E}^{41}, \mathrm{t}^{42}, \mathrm{p}^{43}, \mathrm{CA}^{44}$, \\
$\mathrm{CA}$
\end{tabular}

\begin{tabular}{|c|c|c|}
\hline $\begin{array}{c}\text { Political } \\
\text { Terrorscale }\end{array}$ & $\mathbf{2 0 0 1}$ & $\mathbf{2 0 0 2}$ \\
\hline Conflict Level & $\begin{array}{c}\text { High Intensity }(1,980 \\
\text { killed) and low } \\
\text { intensity conflict } \\
\text { (Kabilye) }\end{array}$ & $\begin{array}{c}\text { High intensity }(1,386 \\
\text { killed) and low } \\
\text { intensity conflict }\end{array}$ \\
\hline $\begin{array}{c}\text { Freedom } \\
\text { House }\end{array}$ & $6 / 5 / \mathrm{NF}$ & $6 / 5 / \mathrm{NF}$ \\
\hline $\begin{array}{c}\text { U.S. State } \\
\text { Department }\end{array}$ & $\mathrm{E}^{46}, \mathrm{t}^{47}, \mathrm{CA}^{48}, \mathrm{CL}^{49}$ & $\mathrm{E}^{50}, \mathrm{t}^{51}, \mathrm{CA}^{52}, \mathrm{CL}^{53}$ \\
\hline
\end{tabular}




\section{Working conditions:}

1989: Enforcement of strict occupational and health regulations is lax.

1990: Enforcement of strict occupational and health regulations is lax.

1991: Enforcement of strict occupational and health regulations is lax.

1992: Enforcement of strict occupational and health regulations is lax.

1993: Minimum wage is insufficient to support a family. Enforcement of laws regarding working conditions is inconsistent. It is not known whether a worker can remove himself from hazardous work situations without risking being fired.

1994: Minimum wage risen. Further pay rises being negotiated. Enforcement of laws regarding working conditions is inconsistent. No reports of workers being removed for refusing to work in hazardous conditions.

1995: Minimum wage risen. Enforcement of laws regarding working conditions is inconsistent. No reports of workers being removed for refusing to work in hazardous conditions.

1996: Minimum wage risen. Enforcement of laws regarding working conditions is inconsistent. No reports of workers being removed for refusing to work in hazardous conditions.

1997: Minimum wage risen, but inadequate to support family. Enforcement of laws regarding working conditions is inconsistent. No reports of workers being removed for refusing to work in hazardous conditions. Standard working week reduced to 40 hours.

1998: Minimum wage risen, but inadequate to support family. Enforcement of laws regarding working conditions is inconsistent. No reports of workers being removed for refusing to work in hazardous conditions.

1999: Minimum wage inadequate to support family. Enforcement of laws regarding working conditions is inconsistent. No reports of workers being removed for refusing to work in hazardous conditions.

2000: Minimum wage risen, but inadequate to support family. Enforcement of laws regarding working conditions is inconsistent. No reports of workers being removed for refusing to work in hazardous conditions.

2001: Minimum wage risen, but inadequate to support family. Enforcement of laws regarding working conditions is inconsistent. No reports of workers being removed for refusing to work in hazardous conditions. Standard workweek reduced to 37.5 hours.

2002: There are very well developed occupation and health regulations codified in the law, but enforcement was lacking. There were no reports of workers being removed for refusing to work in hazardous conditions. Because employment was based on very detailed contracts, workers were rarely subjected to conditions they were not aware off. High unemployment does give the advantage to the employer over the employee.

\section{Brief historical/political overview:}

1962: Independence. Single-party state dominated by military leadership and supported by FLN.

1988: Eruption of urban violence (combined with deteriorating economic conditions) forces steps towards a more open, multiparty political system.

1989: Referendum on Constitution which guarantees fundamental human rights and stipulates transfer to a pluralist republic with a strong president. FLN still only represented party in the National Assembly, as National Assembly elections are still to be held. The local and provincial elections are postponed until the first half of 1990 in order "to give new political parties more time to organize". State Security Court is abolished. President Bendjedid promises prosecution of those responsible for the large scale killings and numerous cases of torture that occurred during the 1988 riots. There is no evidence such action has effectively been undertaken.

1990: President Bendjedid dramatically loosens the party's grip on government policy. Local and provincial elections result for the first time in rule by Islamic and other parties. A general 
amnesty is given to those involved in the events of 1988. The promise to prosecute is thus not kept. National Assembly elections are to be held in June 1991.

1991: In April the National Assembly presents an electoral districting law which is vehemently opposed by FIS. In June FIS organises an (unsuccessful) general strike and calls for early presidential elections. This leads to violent demonstrations in which as many as 300 people die (mostly due to excessive force by security forces). The President declares a state of siege which lasts 4 months. FIS President Abassi Madani and FIS vice-president Ali Belhadj are arrested. At the end of the year (December $26^{\text {th }}$ ) the first round of parliamentary elections are held. FIS clearly win the election.

1992: FLN's rule ends. Dissolution of parliament. President Chadli Benjedid resigns on January 11 after the first round of the elections are won by the FIS (Military and elements in the Government force president out). A day after the regime cancels the second round of parliamentary elections. The second round would most likely have been won by the Islamic Salvation Front. Mohamed Boudiaf heads five-member High State Committee. FIS banned and many leaders in jail. Armed Islamist groups seek to overthrow government and impose Islamic state. In February a state of emergency is announced. Boudiaf is assassinated in June and replaced by Ali Kafi. New antiterrorist law into force.

1993: Human rights situation further deteriorates. Government postpones elections for another 2 or 3 years. State of emergency is extended.

1994: Armed campaign against Government is intensified. Reprisal intensified. Human rights situation further deteriorates.

Jan. 1994: President Zeroual replaces High State Committee.

President opens up talks with political parties and informal contacts with FIS leaders.

Nov. 1 1994: Talks have failed. Presidential elections announced in 1995. State of emergency remains in force.

Nov. 16 1995: Presidential elections. Many opposition parties refuse to participate. In the end four candidates. Zeroual wins $60 \%$ of the vote. Some allegations of fraud and coercion. Not enough to alter the result. Legislative elections and move towards democracy are announced.

1995: Special camps to detain people, administered by the army, are closed. Special Security Courts are abolished. Many organisations contended these courts did not abide by the rule of fair trial.

1996: There is a slight improvement of the human rights situation.

1996: Promise to hold parliamentary elections in the first half of 1997.

1996: President and a few opposition parties sign a national charter encompassing ideas on political reform, review of the constitution and review of electoral laws. The ideas are put to the people in a referendum. They are approved, but referendum was flawed.

1997: Some improvements of the human rights situation. Increase in massacres by armed groups.

1997: Parliamentary elections are held in June and municipal and provincial elections in October. They are the first ever. There are many problems with the conduct of the elections.

1998: There were improvements in some areas of the human rights situation. The number of security incidents involving armed groups and terrorists decreased during the year (and became more localised).

1998: President Zeroual announces he will resign after the completion of multiparty elections to be held before the end of April 1999.

1999: President Abdelaziz Bouteflaki is elected in April (he spent two decades outside of Algeria, but has previously served as a Foreign Minister). Before the elections the six other presidential candidates withdraw, credibly charging the military of massive fraud. The turnout was $30 \%$. After his election Bouteflaki announces that a total of about 100,000 persons have been killed in the previous 8 years. Bouteflaki draws up a peace plan (which includes an amnesty program for the extremists fighting to overthrow the Government). The peace plan is put to the people and approved by a $98 \%$ majority. There were fewer security incidents involving armed groups and terrorists (and the incidents were more localised). After the elections, about 5000 political prisoners were released. In November the judiciary is reorganised by Bouteflaki. As a result of a report by a commission set up by Bouteflaki $80 \%$ of 
all the heads of lower courts and 99\% of the Presidents of the higher level courts are reassigned or fired. There are more women heading courts (19).

2000: Killings by armed groups increases by $20 \%$.

2001: The human rights situation continues to improve. Violence by armed groups decreases. Fifty demonstrators are killed in Kabylie.

2002: Allegations of abuse continued to decline. There were parliamentary elections on May $30^{\text {th }}$, and local elections on October $10^{\text {th }}$. There was a decline in the number of deaths attributed to terrorist groups. During the year 1,386 civilians, terrorists, and security force members died as a result of ongoing violence, a decline from the 1,980 deaths in the previous year. A new trend was reported in that security forces used prolonged detention ranging from 8 to 18 months, this was often reported as a 'disappearance'.

\footnotetext{
${ }^{1}$ Following a directive by Secretary of State Warren Christopher some changes in reporting were made as of the 1993 report. The changes include a stronger emphasis on prison conditions and a new section on "discrimination based on race, sex, religion, disability, language or social status. This new section also includes a paragraph on discrimination against children.

${ }^{2}$ The problem is not widespread, but due to economic hardship the number of children working in the informal sector is increasing.

${ }^{3}$ There were a number of cases of torture. A number of recaptured escapees from Blida prison were tortured by guards. One person accused of car theft was tortured. According to the Algerian League of Human Rights 22 people were tortured after being arrested at violent demonstrations in Tenes.

${ }^{4}$ The problem is not widespread, but due to economic hardship the number of children working in the informal sector is increasing.

${ }^{5}$ The problem is not widespread, but due to economic hardship the number of children working in the informal sector is increasing.

${ }^{6}$ Reportedly between 30 and 60 civilians died in demonstrations and rioting due to use of excessive force by security forces. It is unclear from the report if they should be counted as extrajudicial executions.

${ }^{7}$ There were reports of torture, but less than in previous years.

${ }^{8}$ The problem is not widespread, but due to economic hardship the number of children working in the informal sector is increasing.

${ }^{9}$ Reliable sources report that that are many extrajudicial executions.

${ }^{10}$ There is a systematic use of torture. Some sources say anti terrorism legislation have made torture and other abuse 'easy'.

${ }^{11}$ It is difficult to assess the magnitude of the problem. Hospitals treat dozens of children annually for injuries sustained through abuse, but many cases go unreported. Corporal punishment in school is common.

12 The problem is not widespread, but many children have to work informal jobs, such as street vending, out of pure economic necessity.

${ }^{13}$ Security forces are accused of having killed hundreds of people in retaliation to extremist attacks.

${ }^{14}$ Many died as a result of torture. Torture mainly affects suspected islamists.

${ }^{15}$ It is difficult to assess the magnitude of the problem. Hospitals treat dozens of children annually for injuries sustained through abuse, but many cases go unreported.

${ }^{16}$ The problem is not widespread, but many children have to work informal jobs, such as street vending, out of pure economic necessity.

${ }^{17}$ A prison uprising lead to hundreds of deaths. It is possible these people were executed.

${ }^{18}$ Torture mainly affects suspected islamists.

${ }^{19}$ Overcrowding. Prison conditions are impossible to verify for no independent assessment of the conditions is allowed.

${ }^{20}$ It is difficult to assess the magnitude of the problem. Hospitals treat dozens of children annually for injuries sustained through abuse, but many cases go unreported.

${ }^{21}$ The problem is not widespread, but many children have to work informal jobs, such as street vending, out of pure economic necessity.

${ }^{22}$ Many were extrajudicially executed, but fewer than in recent years.

${ }^{23}$ Torture mainly affects suspected islamists.

${ }^{24}$ Prison conditions are poor. There is severe overcrowding and limited access to medical attention. Independent monitoring of prison conditions is not permitted.

${ }^{25}$ It is difficult to assess the magnitude of the problem. Hospitals treat dozens of children annually for injuries sustained through abuse, but many cases go unreported.

${ }^{26}$ The problem is not widespread, but many children have to work informal jobs, such as street vending, out of pure economic necessity.

${ }^{27}$ Political opponents, particularly persons suspected of being sympathizers of armed groups, were killed by security forces. Serious doubts arose about the way security forces were (not) protecting villagers under attack. Three separate incidents are reported in which hundreds of people were massacred while army barracks were only a few hundred meters away and the army had been called on one occasion by villagers under attack.
} 
${ }^{28}$ Prison conditions are poor. There is severe overcrowding and limited access to medical attention. Independent monitoring of prison conditions is not permitted.

${ }^{29}$ It is difficult to assess the magnitude of the problem. Hospitals treat dozens of children annually for injuries sustained through abuse, but many cases go unreported.

${ }^{30}$ The problem is not widespread, but many children have to work informal jobs, such as street vending, out of pure economic necessity.

${ }^{31}$ Security forces (and progovernment militias) were responsible for numerous extrajudicial killings. Serious doubts arose about the way security forces were (not) protecting villagers under attack.

${ }^{32}$ Prison conditions are poor. There is severe overcrowding and limited access to medical attention. Independent monitoring of prison conditions is not permitted. However an agreement was reached between the International Red Cross and the government on visits to a limited number of prisons after the 1999 elections. A U.N. panel of eminent persons visited one prison.

${ }^{33}$ It is difficult to assess the magnitude of the problem. Hospitals treat dozens of children annually for injuries sustained through abuse, but many cases go unreported.

${ }^{34}$ The problem is not widespread, but many children have to work informal jobs, such as street vending, out of pure economic necessity.

${ }^{35}$ By security forces (and progovernment militias). Serious doubts arose about the way security forces were (not) protecting villagers under attack.

${ }^{36}$ It is impossible to ascertain the exact number of cases of torture. There are many instances of excessive force. In any case there were fewer allegations of torture and a number of torture techniques were known not to used in 1999.

${ }^{37}$ Prison conditions were poor. Prisons were severely overcrowded. There was a lack of medical treatment, food, and reading material. The Government does not permit independent monitoring. However the ICRC was permitted to visit prisons and open an office in Algiers (they did not visit FIS leaders).

${ }^{38}$ Prisoners complained of a lack of food.

${ }^{39}$ Hospitals treat dozens of children annually for injuries sustained through abuse, but many cases go unreported. Child abuse is a problem. Local NGO's attribute an increase in domestic violence to the "culture of violence" developed during the years since 1992 'and the social dislocations caused by the movement of rural families to the cities to escape terrorist violence'.

${ }^{40}$ The problem is not widespread, but many children have to work informal jobs, such as street vending, out of pure economic necessity.

${ }^{41}$ Security forces still committed numerous extrajudicial killings, mainly in clashes with armed terrorist groups. The number of extrajudicial killings decreased again (by Approx. 10\%). Serious doubts arose about the way security forces were (not) protecting villagers under attack.

${ }^{42}$ There still were some reports of torture, but considerably less than in past years. Torture mainly affected those suspected of having sympathies for, or being involved in, armed insurgency groups.

${ }^{43}$ Although prison conditions were poor, they considerably ameliorated in 2000. Overcrowding is still a problem, but there was a decrease of prisoners. Prisoners are in good health and they have sufficient food, but medical attention was still insufficient. The ICRC is permitted to monitor prison conditions.

${ }^{44}$ Hospitals treat dozens of children annually for injuries sustained through abuse, but many cases go unreported. Child abuse is a problem. Local NGO's attribute an increase in domestic violence to the "culture of violence" developed during the years since 1992 'and the social dislocations caused by the movement of rural families to the cities to escape terrorist violence'.

${ }^{45}$ The problem is not widespread, but many children have to work informal jobs, such as street vending, out of pure economic necessity.

${ }_{46}^{46}$ Mostly in clashes with armed terrorist groups. The number of executions decreased by about $19 \%$.

${ }^{47}$ Torture mainly affected those suspected of having sympathies for, or being involved in, armed insurgency groups.

${ }_{48}$ Hospitals treat dozens of children annually for injuries sustained through abuse, but many cases go unreported. Child abuse is a problem. Local NGO's attribute an increase in domestic violence to the "culture of violence" developed during the years since 1992 'and the social dislocations caused by the movement of rural families to the cities to escape terrorist violence'.

${ }^{49}$ The problem is not widespread, but many children have to work informal jobs, such as street vending, out of pure economic necessity.

${ }_{50}$ Most extrajudicial executions took place during clashes with terrorist groups. However 71 civilians were also killed (the majority of those deaths occurred during protests in the Kabylie region).

${ }^{51}$ Police at times resorted to torture mainly against those suspected of being involved with, or having sympathies for, armed insurgency groups. The number of allegations of torture decreased according to the International Red Cross.

${ }^{52}$ Child abuse is a problem. Local NGO's attribute an increase in domestic violence to the "culture of violence" developed during the years since 1992 'and the social dislocations caused by the movement of rural families to the cities to escape terrorist violence'.

${ }^{53}$ Many children have to work informal jobs, such as street vending, out of pure economic necessity. 


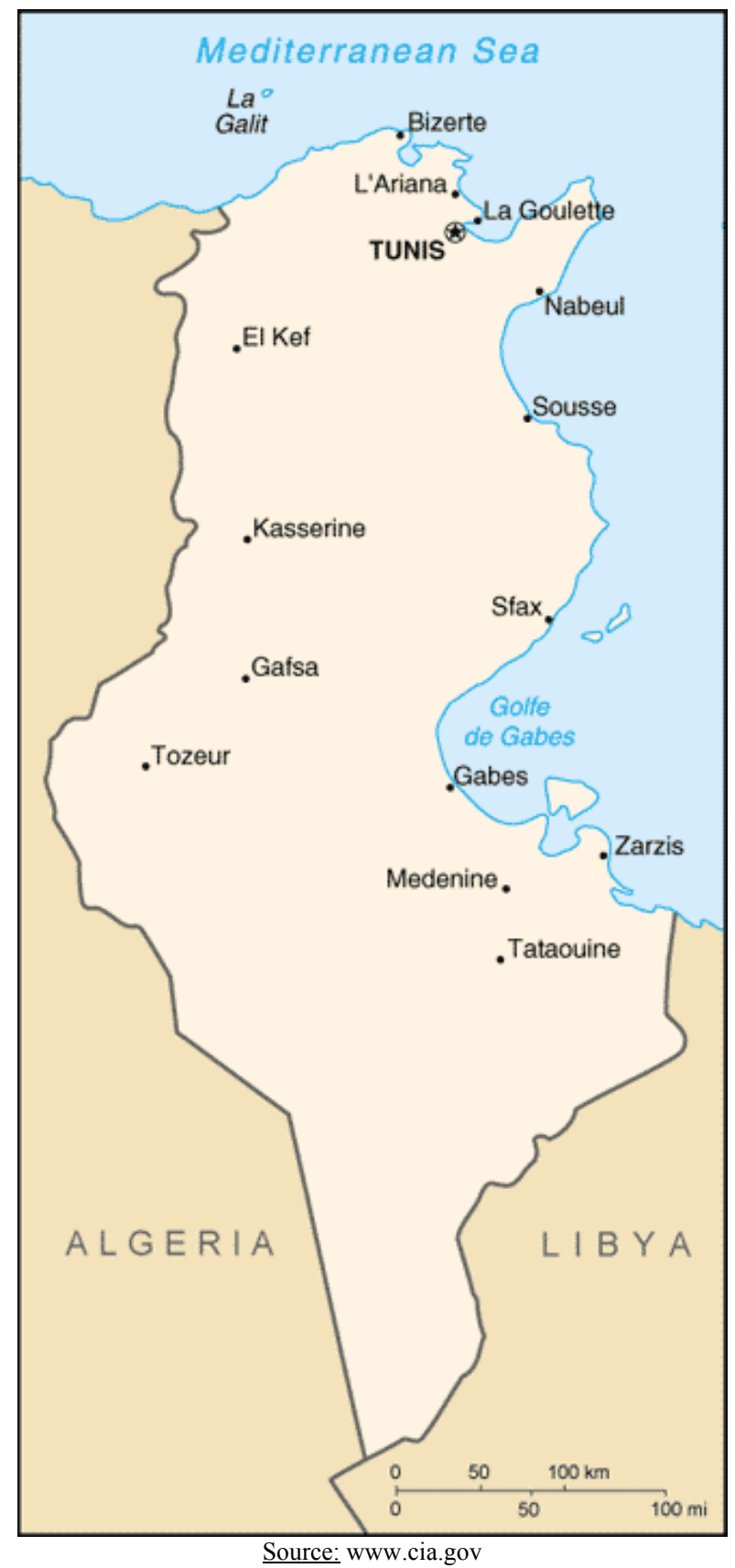

TUNISIA

(Population: 9,924,742)

\begin{tabular}{|c|c|c|c|c|}
\hline & 1989 & 1990 & 1991 & 1992 \\
\hline $\begin{array}{c}\text { Political } \\
\text { Terrorscale }\end{array}$ & $2 / 2$ & $3 / 3$ & $4 / 3$ & $3 / 3$ \\
\hline Conflict Level & & & & \\
\hline $\begin{array}{c}\text { Freedom } \\
\text { House }\end{array}$ & $5 / 3 / \mathrm{PF}$ & $5 / 4 / \mathrm{PF}$ & $5 / 5 / \mathrm{PF}$ & $6 / 5 / \mathrm{PF}$ \\
\hline $\begin{array}{c}\text { U.S. State } \\
\text { Department }\end{array}$ & $\mathrm{t}^{1}, \mathrm{CL}^{2}$ & $(\mathrm{e})^{3}, \mathrm{~T}^{4}, \mathrm{CL}^{5}$ & $\mathrm{e}^{6}, \mathrm{~T}^{7}, \mathrm{CL}^{8}$ & $(\mathrm{e})^{9}, \mathrm{~T}^{10}, \mathrm{CL}^{11}$ \\
\hline
\end{tabular}




\begin{tabular}{|c|c|c|c|c|}
\hline & 1993 & 1994 & 1995 & 1996 \\
\hline $\begin{array}{c}\text { Political } \\
\text { Terrorscale }\end{array}$ & $3 / 3$ & $4 / 3$ & $4 / 2$ & $3 / 2$ \\
\hline Conflict Level & 6/5/NF & $6 / 5 / \mathrm{NF}$ & $6 / 5 / \mathrm{NF}$ & $6 / 5 / \mathrm{NF}$ \\
\hline $\begin{array}{c}\text { Freedom } \\
\text { House }\end{array}$ & $\mathrm{t}^{12}, \mathrm{CL}^{13}$ & $(\mathrm{e})^{14}, \mathrm{t}^{15}, \mathrm{CL}^{16}$ & $(\mathrm{e})^{17}, \mathrm{CL}^{18}$ & $\mathrm{p}^{19}, \mathrm{t}^{20}, \mathrm{CL}^{21}$ \\
\hline $\begin{array}{c}\text { U.S. State } \\
\text { Department }\end{array}$ & & & & \\
\hline
\end{tabular}

\begin{tabular}{|c|c|c|c|c|}
\hline & 1997 & $\mathbf{1 9 9 8}$ & $\mathbf{1 9 9 9}$ & $\mathbf{2 0 0 0}$ \\
\hline $\begin{array}{c}\text { Political } \\
\text { Terrorscale }\end{array}$ & 2 & 3 & & 3 \\
\hline Conflict Level & & & & \\
\hline $\begin{array}{c}\text { Freedom } \\
\text { House }\end{array}$ & $6 / 5 / \mathrm{NF}$ & $6 / 5 / \mathrm{NF}$ & $6 / 5 / \mathrm{NF}$ & $6 / \mathrm{NF}$ \\
\hline $\begin{array}{c}\text { U.S. State } \\
\text { Department }\end{array}$ & $(\mathrm{e})^{22}, \mathrm{p}^{23}, \mathrm{t}^{24}, \mathrm{CL}^{25}$ & $(\mathrm{e})^{26}, \mathrm{p}^{27}, \mathrm{~T}^{28}, \mathrm{CL}^{29}$ & $\mathrm{e}^{30}, \mathrm{p}^{31}, \mathrm{~T}, \mathrm{CL}^{32}$ & $\mathrm{e}^{33}, \mathrm{p}^{34}, \mathrm{~T}^{35}, \mathrm{CL}^{36}$ \\
\hline
\end{tabular}

\begin{tabular}{|c|c|c|}
\hline $\begin{array}{c}\text { Political } \\
\text { Terrorscale }\end{array}$ & $\mathbf{2 0 0 1}$ & $\mathbf{2 0 0 2}$ \\
\hline Conflict Level & & \\
\hline $\begin{array}{c}\text { Freedom } \\
\text { House }\end{array}$ & $6 / 5 / \mathrm{NF}$ & $6 / 5 / \mathrm{NF}$ \\
\hline $\begin{array}{c}\text { U.S. State } \\
\text { Department }\end{array}$ & $\mathrm{e}^{37}, \mathrm{p}^{38}, \mathrm{~T}^{39}, \mathrm{CL}^{40}$ & $\mathrm{e}^{41}, \mathrm{p}^{42}, \mathrm{~T}, \mathrm{CL}^{43}$ \\
\hline
\end{tabular}


1989: Legislation on "rehabilitation" and compulsory work on economic and social development projects is not in conformity with ILO Convention on Forced Labour. Inadequate enforcement of health and safety regulations in hazerdous jobs. 200 work related deaths.

1990: Legislation on "rehabilitation" and compulsory work on economic and social development projects is not in conformity with ILO Convention on Forced Labour.Inadequate enforcement of health and safety regulations in hazerdous jobs. In Tunis inspections are good, but outside of Tunis, where most of the construction work is done in the informal sector, inspections are lacking.

1991: Legislation on "rehabilitation" and compulsory work on economic and social development projects is not in conformity with ILO Convention on Forced Labour.Inadequate enforcement of health and safety regulations in hazerdous jobs. In Tunis inspections are good, but outside of Tunis, where most of the construction work is done in the informal sector, inspections are lacking.

1992: Legislation on "rehabilitation" and compulsory work on economic and social development projects is not in conformity with ILO Convention on Forced Labour.Inadequate enforcement of health and safety regulations in hazerdous jobs. In Tunis inspections are good, but outside of Tunis, where most of the construction work is done in the informal sector, inspections are lacking. In 1992 a new labour code on work related illnessess and accidents was enacted.

1993: There are special government regulations covering such hazardous occupations as mining, petroleum engineering, and construction. Inadequate enforcement of health and safety regulations in hazerdous jobs. In Tunis inspections are good, but outside of Tunis, where most of the construction work is done in the informal sector, inspections are lacking. Working conditions tend to be better in firms that are export oriented. Workers are free to remove themselves from dangerous situations without jeopardising their employment, and they may take legal against employers who retaliate against them for exercising this right.

1994: There are special government regulations covering such hazardous occupations as mining, petroleum engineering, and construction. Inadequate enforcement of health and safety regulations in hazerdous jobs. In Tunis inspections are good, but outside of Tunis, where most of the construction work is done in the informal sector, inspections are lacking. Working conditions tend to be better in firms that are export oriented. Workers are free to remove themselves from dangerous situations without jeopardising their employment, and they may take legal against employers who retaliate against them for exercising this right. Reported workplace accidents during the first six months of 1994 indicate a decline of $0.9 \%$ in mishaps over the same period in 1993. Work-related deaths increased to 82 in the first six months of the year, compared to 76 from the same period in 1993.

1995: There are special government regulations covering such hazardous occupations as mining, petroleum engineering, and construction. Inadequate enforcement of health and safety regulations in hazerdous jobs. In Tunis inspections are good, but outside of Tunis, where most of the construction work is done in the informal sector, inspections are lacking. Working conditions tend to be better in firms that are export oriented. Workers are free to remove themselves from dangerous situations without jeopardising their employment, and they may take legal against employers who retaliate against them for exercising this right.

1996: There are special government regulations covering such hazardous occupations as mining, petroleum engineering, and construction. Working conditions tend to be better in firms that are export oriented. Workers are free to remove themselves from dangerous situations without jeopardising their employment, and they may take legal against employers who retaliate against them for exercising this right.

1997: There are special government regulations covering such hazardous occupations as mining, petroleum engineering, and construction. Working conditions tend to be better in firms that are export oriented. Workers are free to remove themselves from dangerous situations without jeopardising their employment, and they may take legal against employers who retaliate against them for exercising this right. 
1998: There are special government regulations covering such hazardous occupations as mining, petroleum engineering, and construction. Working conditions tend to be better in firms that are export oriented. Workers are free to remove themselves from dangerous situations without jeopardising their employment, and they may take legal against employers who retaliate against them for exercising this right.

1999: There are special government regulations covering such hazardous occupations as mining, petroleum engineering, and construction. Working conditions tend to be better in firms that are export oriented. Workers are free to remove themselves from dangerous situations without jeopardising their employment, and they may take legal against employers who retaliate against them for exercising this right.

2000: There are special government regulations covering such hazardous occupations as mining, petroleum engineering, and construction. Working conditions tend to be better in firms that are export oriented. Workers are free to remove themselves from dangerous situations without jeopardising their employment, and they may take legal against employers who retaliate against them for exercising this right.

2001: There are special government regulations covering such hazardous occupations as mining, petroleum engineering, and construction. Working conditions tend to be better in firms that are export oriented. Workers are free to remove themselves from dangerous situations without jeopardising their employment, and they may take legal against employers who retaliate against them for exercising this right.

2002: There are special government regulations covering such hazardous occupations as mining, petroleum engineering, and construction. Working conditions tend to be better in firms that are export oriented. Workers are free to remove themselves from dangerous situations without jeopardising their employment, and they may take legal against employers who retaliate against them for exercising this right.

\section{Brief historical/political overview}

1987: President Ben Ali assumes power.

1989: President Ben Ali is reelected. He was unopposed. His ruling Constitutional Democratic Party (RCD) won all seats in the Chamber of Deputies. Voting was influenced by the winnertake-all voting system, the inability of many voters to register, and heavy-handed RCD tactics. Although Islamist independents averaged 18 percent of the vote wherever they ran, the Islamist party An Nahda continued to be denied legal status.

1990: Some members of the previously little independent Chamber of Deputies voiced criticism on the press laws and challenging drafted legislation. Two parliamentary by-elections were boycotted by the opposition. New legislation introduced modified proportional representation for the June municipal elections, but these were also boycotted by the opposition. The elections continued to be influenced by the same factors as in 1989. The regime became increasingly repressive, especially against Islamists (and police stepped up their presence around universities and mosques). One demonstration by Islamists turned violent.

1991: By-elections in October were boycotted by the opposition, because of the lack of press freedom and access to government controlled media and the ruling party's monopoly over the administration. The largest opposition party, the islamist An Nahda, suffered enormous setback as islamists attacked a RCD bureau killing one guard and injuring another. Members of the Executive Bureau of An Nahda resigned, and the government announced the arrest of 238 persons in connection with an alledged plot to overthrow the Government. In the aftermath of the alledged coup the human rights situation deteriorated. 4,000 islamists were arrested.

1992: An Nahda was dealt a severe blow as 265 of its top memebers were sentenced to prison sentences ranging from 1 year to life after being convicted by two military tribunals for plotting to assassinate the President and overthrow the Government. The Government undertook serious initiatives in the human rights area, but significant restrictions remained. The crackdown on An Nahda was completed, but memebrs and their family continued to be harassed. New legislation led to the closure of the Tunisian League for Human Rights. The Govenrment guaranteed more accountability for human rights abuses and further opened the media to opposition party views. 
1993: Arrests of of Islamists and some leftists continued in 1993.

1994: Ben Ali is elected for a second five-year term in March. He ran unopposed. The RCD won 144 out 163 seats. The 19 remaining seats are held by four nominal opposition parties. Two self-proclaimed presidential candidates, as well as an opposition candidate for Parliament who complained to a foreign journalist about the results of the national elections, were imprisoned by the Government. Arrests of of Islamists and some leftists continued.

1995: In municipal elections the RCD won 4,084 of 4,090 seats. Human rights situation ameliorated somewhat in the first half of the year, but deteriorated in the second half of the year. The LTDE was refused visits to prisons.

1996: Human rights situation did not improve. Repression of civil liberties continued, as well as continued reports of torture, poor prison conditions and impunity. The European passed a resolution criticising Tunisia's human rights policy. They expressely linked economic cooperation with respect for human rights and democratic principles. Upon this the Government allowed periodic monitoring of the human rights situation and to engage in discussions on human rights with its European partners.

1997: Human rights performance by the Government improved in some important areas, however serious abuses continued to be committed.

1998:

1999: Elections were overwhelmingly won by the ruling RCD. Following a reform in the Constitution two candidates were allowed to run against the President in the presidential elections, this was the first time ever in the history of Tunisia. The Electoral Code also provided for $20 \%$ of seats in the Chamber of Deputies to go to the opposition (up from $10 \%$ at the previous election.

2000:

2001: The constitution provides for that a person may serve only three terms as President. However the RCD has requested President Ben Ali to seek a fourth term. This would require a constitutional amendment.

2002: On June 1 nearly half of the constitution was amended after the Government initiated changes that, among other things, removed term limits for the presidency, raised the age limit of presidential candidates, granted immunity to the President for acts committed while in office, and created a second legislative chamber. In May the Government had put the amendments to a national referendum and stated that it passed with $99.52 \%$ of the vote. Credible reports indicate the vote was characterised by intimidation and that there was no secret ballot. In June LTDH released a report, the first of its kind since 1994, indicating the human rights situation had deteriorated. Pro-Palestinian demonstrations mostly at universities and high schools erupted into spontaneous demonstrations. Some resulted in violent confrontations between demonstrators and police. A terrorist attack outside a synagogue, on April 11 killed 21 people.

\footnotetext{
${ }^{1}$ Of opposition supporters: islamists and communists.

${ }^{2}$ Young children often perform agricultural work in rural areas and sell food and other items in urban areas.

${ }^{3}$ Four deaths in suspicious circumstances.

${ }^{4}$ Torture increased. There were 120 complaints of torture in the first nine months of the year.

${ }^{5}$ Young children often perform agricultural work in rural areas and sell food and other items in urban areas. The problem of child labour has increased, because child labour is frequently disguised as an apprenticeship.

${ }^{6}$ There were seven deaths under suspicious circumstances. Probably due to torture. There were five students killed in rioting. The government called the deaths accidental. However independent observers reported the deaths were due to excessive use of force.

${ }^{7}$ There were an increased number of credible reports of torture. Especially due to the alledged coup against the Government. In the face of national and international criticism against the human rights situation in Tunisia, the Government established a committee to investigate the allegations. The Committee's chairman acknowledged excesses and recommended a number of changes in laws. It seems the Government is more willing to prosecute offenders.

${ }^{8}$ Young children often perform agricultural work in rural areas and sell food and other items in urban areas. The problem of child labour has increased, because child labour is frequently disguised as an apprenticeship.

${ }^{9}$ There was one death under suspicious circumstances.

${ }^{10}$ There were credible reports that torture continued to be used. It would seem from the report the problem is not increasing. Most of the victims were islamists. Police officers were increasingly given training in human rights
} 
and the Government seems to prosecute offenders more often. However it is to premature to state that the culture of impunity has been reversed.

${ }^{11}$ Young children often perform agricultural work in rural areas and sell food and other items in urban areas. The problem of child labour is serious. Child labour is frequently disguised as an apprenticeship.

${ }_{12}$ Torture persists, but is not systematic or widespread any more.

${ }^{13}$ Young children often perform agricultural work in rural areas and sell food and other items in urban areas. The problem of child labour is serious. Child labour is frequently disguised as an apprenticeship. Young girls from rural areas are sometimes placed as domestics in urban homes by ytheir fathers, who collect the child's wages.

${ }^{14}$ Three persons died in police custody. Two alledgedly commited suicide. One alledgedly died of pneumonia. A fourth death in custody remained unconfirmed.

${ }^{15}$ Complaints of torture declined.

${ }^{16}$ Young children often perform agricultural work in rural areas and work as vendors in urban areas. Child labour is frequently disguised as an apprenticeship. Young girls from rural areas are sometimes placed as domestics in urban homes by ytheir fathers, who collect the child's wages.

${ }^{17}$ Two prisoners died while in custody. One died alledgedly by committing suicide, the other was alledgedly killed by another inmate. The Government confirmed the death in August 1994 of an Islamist who had been in prison since his conviction in 1991-1992. The Government claims he died of a heart attack. However the family of the deceased claim foul play.

${ }^{18}$ Young children often perform agricultural work in rural areas and work as vendors in urban areas. Child labour is frequently disguised as an apprenticeship. Young girls from rural areas are sometimes placed as domestics in urban homes by ytheir fathers, who collect the child's wages.

${ }^{19}$ Prison conditions range from spartan to poor. There was overcrowding and inadequate medical care. The regime was more severe for political prisoners. Only after the President visited certain prisons this year, was the National Human Rights Commissioner allowed to make unannounced visits (which it subsequently did in two separate facilities).

${ }^{20}$ Security forces employ various means of torture. However allegations of torture are difficult to substantiate.

${ }^{21}$ The minimum age for working in manufacturing was raised from 15 to 16 . Many children work in agriculture in rural areas and street vending in urban areas.

${ }^{22}$ There were three cases of possible killings. One case was that of an older lady who's house was searched as her son was arrested. She was alledgedly pushed over by security forces and died of her injuries. Another cases was the case of an activist in prison who died from a hunger strike. NGO's alledge negligence from the authorities killed him. The last case was that of an asthmatic who died after the authorities alledgedly failed to provide him with adequate medical attemtion.

${ }^{23}$ Conditions ranged from spartan to poor, as there was overcrowding, lack of access to water and toilet facilities.

${ }^{24}$ Security forces employ various means of torture. However allegations of torture are difficult to substantiate.

${ }^{25}$ Many children work in agriculture in rural areas and street vending in urban areas, primarliy during summer vacation.

${ }^{26}$ There was one possible killing. A former islamist prisoner died in custody in suspicious circumstances.

${ }^{27}$ Conditions ranged from spartan to poor, and did not in some cases meet minimum international standards. There was overcrowding, insufficient water and toilet facilities. There were serious sanitation problems. Once more rules were more stringent for political prisoners.

${ }^{28} \mathrm{FIDH}$ is quoted saying torture is systematic.

${ }^{29}$ Many children work in agriculture in rural areas and street vending in urban areas, primarliy during summer vacation. The use of child labour under the disguise of apprenticeship remains an area of concern. It is reported that the placing of teenage girls in families in order to let them work as domestics is common. The families of the girls aim to collect the girl's wages.

${ }^{30}$ The report states that according to one prison report of Khemais Ksila published by AI one prisoner died of torture. The State Department report does not mention a reply by the authorities. This leads to believe the prison report is credible and reflects what happened.

${ }^{31}$ Conditions ranged from spartan to poor, and did not in some cases meet minimum international standards. There was overcrowding, insufficient water and toilet facilities. There were serious sanitation problems. Once more rules were more stringent for political prisoners.

${ }^{32}$ Many children work in agriculture in rural areas and street vending in urban areas, primarliy during summer vacation. The use of child labour under the disguise of apprenticeship remains an area of concern. It is reported that the placing of teenage girls in families in order to let them work as domestics is common. The families of the girls aim to collect the girl's wages.

${ }_{33}^{33}$ There were two cases of extrajudicial killing and one case of gross negligence by prison authorities.

${ }^{34}$ Conditions ranged from spartan to poor, and did not in some cases meet minimum international standards. There was overcrowding, insufficient water and toilet facilities. There were serious sanitation problems. Once more rules were more stringent for political prisoners.

${ }^{35}$ It is the first time a report itself mentions the routine use of torture. There were allegations of severe beatings at demonstrations in February and October.

${ }^{36}$ Many children work in agriculture in rural areas and street vending in urban areas, primarliy during summer vacation. The use of child labour under the disguise of apprenticeship remains an area of concern. It is reported 
that the placing of teenage girls in families in order to let them work as domestics is common. The families of the girls aim to collect the girl's wages. Child labour is decling due to serious government efforts.

${ }^{37}$ There were four deaths in custody in which security forces were directly involved or in which they were accused of complicity.

${ }^{38}$ Conditions ranged from spartan to poor, and did not in some cases meet minimum international standards. There was overcrowding, insufficient water and toilet facilities. There were serious sanitation problems. Once more rules were more stringent for political prisoners. There were several hunger strikes during the year. There seems to be some attempt to reform the prison system, as the authority was referred from the Ministry of the Interior to the Ministry of Justice. This has not as yet resulted in any change.

${ }^{39}$ Once again there were severe beating during demonstrations. RCD students attacked opposing candidates running for scientific councils.

${ }^{40}$ There is some child labour. Many children work in agriculture in rural areas and street vending in urban areas, primarliy during summer vacation. The use of child labour under the disguise of apprenticeship remains an area of concern. It is reported that the placing of teenage girls in families in order to let them work as domestics is common. The families of the girls aim to collect the girl's wages.

${ }^{41}$ There were deaths in which security forces were directly or indirectly implicated.

${ }^{42}$ Conditions ranged from spartan to poor, and did not in some cases meet minimum international standards. There was overcrowding, insufficient water and toilet facilities. There were serious sanitation problems. Once more rules were more stringent for political prisoners. There were several hunger strikes during the year. There seemed to be some attempt to reform the prison system in 2001, as the authority was referred from the Ministry of the Interior to the Ministry of Justice. This has still not resulted in any change.

${ }^{43}$ There is some child labour. Many children work in agriculture in rural areas and street vending in urban areas, primarliy during summer vacation. The use of child labour under the disguise of apprenticeship remains an area of concern. It is reported that the placing of teenage girls in families in order to let them work as domestics is common. The families of the girls aim to collect the girl's wages. This practice, as well as child labour in general, declined during the year, due to government involvement. 


\section{MALI}

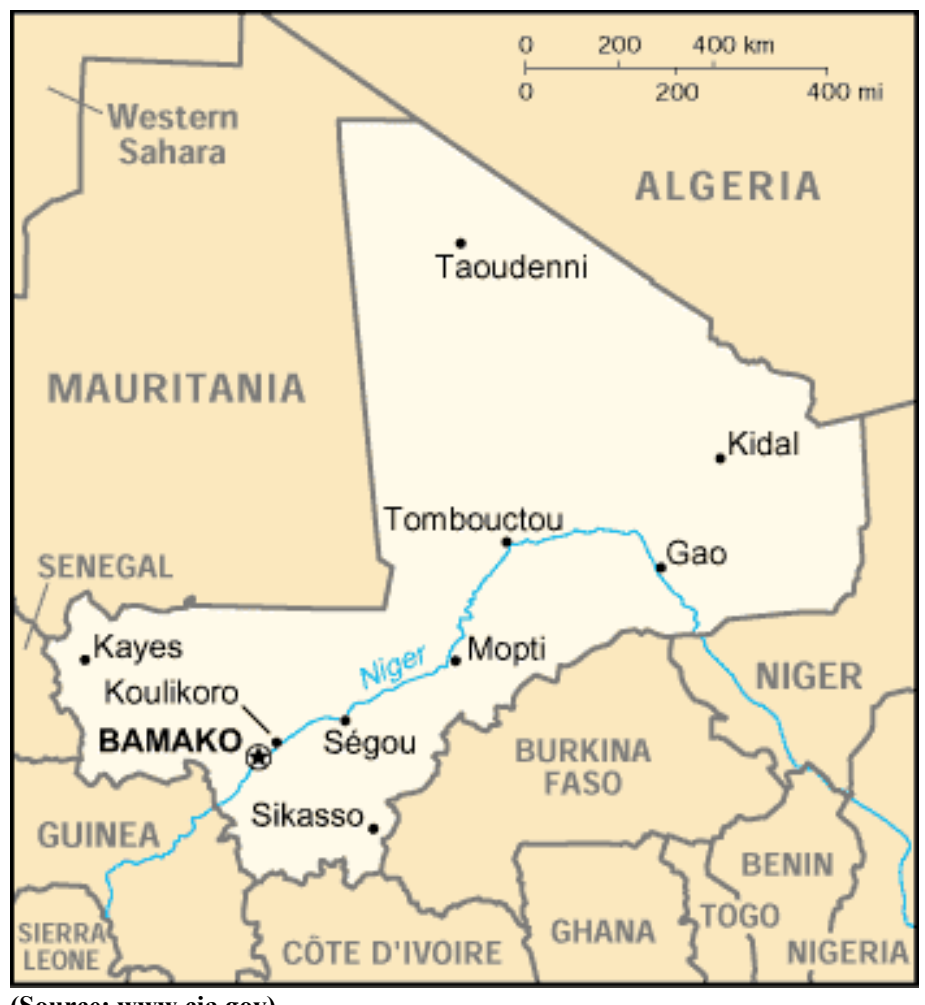

(Source: www.cia.gov)

\begin{tabular}{|c|c|c|c|c|}
\hline & 1989 & $\mathbf{1 9 9 0}$ & $\mathbf{1 9 9 1}$ & 1992 \\
\hline $\begin{array}{c}\text { Political Terror } \\
\text { scale }\end{array}$ & $\begin{array}{c}2 / 2 \\
(\mathrm{a} / \mathrm{s})\end{array}$ & $4 / 3$ & $4 / 3$ & $3 / 3$ \\
\hline $\begin{array}{c}\text { Conflict Level } \\
\text { Freedom } \\
\text { House }\end{array}$ & - & $\begin{array}{c}\text { Violent Political } \\
\text { Conflict }\end{array}$ & $\begin{array}{c}\text { Low Intensity } \\
\text { Conflict }\end{array}$ & $\begin{array}{c}\text { Low Intensity } \\
\text { Conflict }\end{array}$ \\
\hline $\begin{array}{c}\text { U.S. State } \\
\text { Department }\end{array}$ & $(\mathrm{CL})^{1},(\mathrm{FL})^{2}, \mathrm{p}^{3}, \mathrm{IF}^{4}$ & $\begin{array}{c}(\mathrm{CL})^{5},(\mathrm{FL})^{6}, \mathrm{E}^{7}, \mathrm{p}^{8}, \\
\mathrm{t}^{9}\end{array}$ & $\begin{array}{c}(\mathrm{CL})^{10},(\mathrm{FL})^{11}, \mathrm{E}^{12}, \\
\mathrm{p}^{13},(\mathrm{t})^{14}, \mathrm{D}^{15}\end{array}$ & $\begin{array}{c}\mathrm{E}^{16}, \mathrm{p}^{17}, \mathrm{D}^{18},(\mathrm{CL})^{19}, \\
(\mathrm{FL})^{20}\end{array}$ \\
\hline $\begin{array}{c}\text { Amnesty } \\
\text { International }\end{array}$ & $(\mathrm{t})^{21}$ & $\mathrm{D}^{22}, \mathrm{FE}^{23}, \mathrm{p}^{24}, \mathrm{t}^{25}, \mathrm{E}^{26}$ & $\mathrm{E}^{27}, \mathrm{t}^{28}, \mathrm{P}^{29}, \mathrm{PC}^{30}$ & $\mathrm{E}^{31},(\mathrm{t})^{32}$ \\
\hline
\end{tabular}




\begin{tabular}{|c|c|c|c|c|}
\hline & 1993 & 1994 & 1995 & 1996 \\
\hline $\begin{array}{c}\text { Political Terror } \\
\text { scale }\end{array}$ & $3 / 1$ & $3 / 3$ & $3 / 1$ & $1 / 1$ \\
\hline Conflict Level & $\begin{array}{c}\text { Violent Political } \\
\text { Conflict }\end{array}$ & $\begin{array}{l}\text { Low Intensity } \\
\text { Conflict }\end{array}$ & - & $\begin{array}{c}\text { Violent Political } \\
\text { Conflict }\end{array}$ \\
\hline $\begin{array}{l}\text { Freedom } \\
\text { House }\end{array}$ & $2 / 3 / \mathrm{F}$ & $2 / 4 / \mathrm{PF}$ & $2 / 3 / \mathrm{F}$ & $2 / 2 / \mathrm{F}$ \\
\hline $\begin{array}{c}\text { U.S. State } \\
\text { Department }\end{array}$ & $\begin{array}{l}\mathrm{PC}^{33},(\mathrm{e})^{34}, \mathrm{AE}^{35} \\
(\mathrm{CL})^{36},(\mathrm{FL})^{37}\end{array}$ & $\begin{array}{c}\mathrm{E}^{38}, \mathrm{p}^{39},(\mathrm{CL})^{40} \\
(\mathrm{FL})^{41}, \mathrm{AE}^{42}, \mathrm{PC}^{43}\end{array}$ & $\begin{array}{c}\mathrm{p}^{44}, \mathrm{PC}^{45}, \mathrm{AE}^{46}, \\
(\mathrm{CL})^{47},(\mathrm{FL})^{48}\end{array}$ & $\begin{array}{l}\mathrm{p}^{49}, \mathrm{PC}^{50}, \mathrm{AE}^{51}, \\
(\mathrm{CL})^{52},(\mathrm{FL})^{53}\end{array}$ \\
\hline $\begin{array}{c}\text { Amnesty } \\
\text { International }\end{array}$ & $E^{54}$ & $E^{55}$ & $E^{56}$ & $\mathrm{t}^{57}$ \\
\hline
\end{tabular}

\begin{tabular}{|c|c|c|c|c|}
\hline & 1997 & 1998 & 1999 & 2000 \\
\hline $\begin{array}{c}\text { Political Terror } \\
\text { scale }\end{array}$ & $2 / 2$ & $2 / 2$ & & $2 / 2$ \\
\hline Conflict Level & \multicolumn{2}{|c|}{$\begin{array}{l}\text { Violent Political Conflict } \\
\text { Mid 1997-mid } 1998\end{array}$} & \multicolumn{2}{|c|}{$\begin{array}{l}\text { Violent Political Conflict } \\
\text { Mid 1999-mid } 2000\end{array}$} \\
\hline $\begin{array}{l}\text { Freedom } \\
\text { House }\end{array}$ & $3 / 3 / F$ & $3 / 3 / F$ & $3 / 3 / F$ & - \\
\hline $\begin{array}{c}\text { U.S. State } \\
\text { Department }\end{array}$ & $\begin{array}{c}\mathrm{p}^{58}, \mathrm{PC}^{59}, \mathrm{AE}^{60}, \mathrm{CL}^{61}, \\
(\mathrm{FL})^{62}, \mathrm{t}^{63}\end{array}$ & $\begin{array}{c}\mathrm{p}^{64}, \mathrm{PC}^{65}, \mathrm{AE}^{66}, \mathrm{CL}^{67} \\
\mathrm{FL}^{68}, \mathrm{t}^{69}, \mathrm{TL}^{70},(\mathrm{e})^{71}\end{array}$ & $\begin{array}{c}\mathrm{p}^{72}, \mathrm{PC}^{73}, \mathrm{AE}^{74}, \mathrm{CL}^{75} \\
\mathrm{FL}^{76}, \mathrm{TL}^{77}\end{array}$ & $\begin{array}{c}\mathrm{CA}^{78}, \mathrm{p}^{79}, \mathrm{PC}^{80}, \\
\mathrm{AE}^{81}, \mathrm{CL}^{82}, \mathrm{FL}^{83}, \\
\mathrm{t}^{84}, \mathrm{e}^{85}, \mathrm{TL}^{86}\end{array}$ \\
\hline
\end{tabular}




\begin{tabular}{|c|c|c|}
\hline & 2001 & 2002 \\
\hline $\begin{array}{c}\text { Political Terror } \\
\text { scale }\end{array}$ & $2 / 2$ & $2 / 2$ \\
\hline $\begin{array}{c}\text { Conflict Level } \\
\text { Freedom } \\
\text { House }\end{array}$ & \multicolumn{2}{|c|}{$\begin{array}{c}\text { Violent political Conflict } \\
\text { Mid 2000-mid 2001 }\end{array}$} \\
\hline $\begin{array}{c}\text { U.S. State } \\
\text { Department }\end{array}$ & $\begin{array}{c}\mathrm{CA}^{87}, \mathrm{p}^{88}, \mathrm{PC}^{89}, \\
\mathrm{CL}^{91}, \mathrm{FL}^{92},\end{array}$ & $\mathrm{CA}^{93} \mathrm{AE}^{97}, \mathrm{CL}^{98}, \mathrm{PL}^{99}$, \\
$\mathrm{TL}^{100}$
\end{tabular}




\section{Working conditions:}

1989: Constitution provides liberties to workers, but in reality workers' right of association is limited. High government influence and control in Mali's only recognised workers' organisation (UNTM). Strikes are rare because of fear of losing jobs, unemployment rate is high. Strike for political reasons are illegal and mostly reprisals follow. ILO Committee on Freedom of association concluded that the actions of the government towards a teachers strike were an infringement of the freedom of association. No true collective bargaining because of Mali's unitary party system. Reports show that there is still a form of traditional slavery in some isolated parts of the country. Children in rural areas join the workforce more early then legally 14 years or 12 years with consent of the parents. No protection against unjust compensation excessive hours and capricious discharge. Lack of inspectors for acceptable conditions of work.

1990: Constitution provides liberties to workers, but in reality workers' right of association is limited. High government influence and control in Mali's only recognised workers' organisation (UNTM). But the UNTM takes positions independent of the Government. Strikes are rare because of fear of losing jobs, unemployment rate is high. Strike for political reasons are illegal and mostly reprisals follow. No true collective bargaining because of Mali's unitary party system. Reports show that there is still a form of traditional slavery in some isolated parts of the country, mostly debt slavery in salt mining communities north of Timbuktu. Work is under primitive and dangerous conditions. Debt and obligation often passes from one generation to the next. Children in rural areas join the workforce more early then legally 14 years or 12 years with consent of the parents. No protection against unjust compensation excessive hours and capricious discharge. Lack of inspectors for acceptable conditions of work. 1991: The new Constitution specifically provides for the freedom of workers to form or join unions and does not limit them to the National Union of Malian Workers (UNTM). The UNTM this time was a leading force in changing the regime. Three of its members are now in the Transitional Government. There is an explicit right to strike and this right has been used several times this year. They were generally resolved by negotiations between the labour unions and the new Government. There also was a reduction is constraints for workers to organize and bargain collectively. Next to that there still is some debt slavery in salt mining in the North where also children are probably active. Important to note is that since the change of the regime many of those treated as slaves have refused to continue working under those conditions. Children in rural areas join the workforce more early then legally 14 years or 12 years with consent of the parents. No protection against unjust compensation excessive hours and capricious discharge. Lack of inspectors for acceptable conditions of work.

1992: The new Constitution specifically provides for the freedom of workers to form or join unions and does not limit them to the National Union of Malian Workers (UNTM). The UNTM this time was a leading force in changing the regime. There also was a reduction is constraints for workers to organize and bargain collectively. Next to that there still is some debt slavery in salt mining in the North where also children are probably active. Important to note is that since the change of the regime many of those treated as slaves have refused to continue working under those conditions. And the Government does not force the fled slaves back to go to work. It has even helped some former slaves to settle in villages. Children in rural areas join the workforce more early then legally 14 years or 12 years with consent of the parents. No protection against unjust compensation excessive hours and capricious discharge. Lack of inspectors for acceptable conditions of work.

1993: idem 1992.

1994: idem 1992 + Virtually all salaried employees are organised in unions now. True collective bargaining still doesn't take place.

1995: idem 1994

1996: idem 1995

1997: idem 1996 + UNTM fragmented into small groups over a dispute of leadership. But they almost all reconstituted. The growth of independent unions has led to more direct bargaining between unions and their employers. Labour code adopted that has specific policies pertaining child labour. It enforces the protection of children through labour inspectors, but resources are 
limited. Regulations are often ignored in practice and Labour Code has no effect on the vast number of children in the rural areas.

1998: idem 1997+ more emphasis on the Labour Code for Children. But still regulations are ignored and even now there are cases of trafficking sold children to Cote D'Ivoire into forced labour. The Government is taking steps against this and 55 children were returned to their parents and arrested some traffickers.

1999: idem 1997+ more emphasis on the Labour Code for Children. But still regulations are ignored and even now there are cases of trafficking sold children to Cote D'Ivoire into forced labour. The Government is taking steps against this and 5 children were returned to their parents but did not arrest traffickers.

2000: idem 1998 + The government ratified ILO Convention 182 on the worst forms of child labour on July 14. Combat against Child Labour is getting stronger and the government and ngo's are more active. Some 50 children were returned from TL in Cote D'Ivoire.

2001: In June in Bamako bus drivers attacked the police following the death of a bus driver. The drivers Union agreed to use union funds o pay for repairs to traffic lights and other public facilities damaged in the riots. Government keeps on taking steps to halt child trafficking. Some 300 children were returned to their families (=children that went through welcome centres, others were not counted). In August 2000 the government signed a treaty with Cote D'Ivoire to cooperate in combating trafficking. Around 10 traffickers were arrested.

2002: In 2001 the Government negotiated with all labour unions a social pact, intended to encourage more discussions between workers and employers, thus lessening the risks of strikes. $\mathrm{TL} / \mathrm{CL} / \mathrm{FL}$ remain a persistent problem.

\section{Brief historical/political overview:}

\section{Background:}

The Sudanese Republic and Senegal became independent of France in 1960 as the Mali Federation. When Senegal withdrew after only a few months, the Sudanese Republic was renamed Mali. Rule by dictatorship was brought to a close in 1991 with a transitional government, and in 1992 when Mali's first democratic presidential election was held. After his re-election in 1997, President Alpha KONARE continued to push through political and economic reforms and to fight corruption. In keeping with Mali's two-term constitutional limit, he stepped down in 2002 and was succeeded by Amadou TOURE.

\section{Economy - overview:}

Mali is among the poorest countries in the world, with $65 \%$ of its land area desert or semi desert. Economic activity is largely confined to the riverine area irrigated by the Niger. About $10 \%$ of the population is nomadic and some $70 \%$ of the labour force is engaged in farming and fishing. Industrial activity is concentrated on processing farm commodities. Mali is heavily dependent on foreign aid and vulnerable to fluctuations in world prices for cotton, its main export. In 1997, the government continued its successful implementation of an IMFrecommended structural adjustment program that is helping the economy grow, diversify, and attract foreign investment. Mali's adherence to economic reform and the $50 \%$ devaluation of the African franc in January 1994 have pushed up economic growth to a sturdy 5\% average in 1996-2000. In 2001, GDP decreased by $1.2 \%$ mainly due to a $50 \%$ drop in cotton production in 2000-01.

1989: Military still has a strong and privileged position since the military coup of 1968 and the new Constitution of 1974. Good rainfalls for the second year in a row increased agricultural production and permitted some export of grain, but malnutrition and poor food distribution remain persistent problems. Military regime controls large parts of media and judiciary. Baha' $i$, a religious group, has the right to practice at home, but not proselytise or establish houses of worship. Female Genital Mutilation (FMG) is practised widely, including infibulation (most extreme form). Women's position overall harsh conditions. Citizens have no ability to change their government and only limited and infrequent opportunity to influence it. 
1990: Although some human rights restrictions eased in 1990, the government's response to Tuareg dissidence in the North resulted in numerous credible reports of human rights violations. There have been attacks and fights between the Toearegs and the government supposingly because of the fact that the Toearegs felt that the government didn't come up for their causes (primarily because a very poor coordinated repatriation of several thousands Malians, mainly Tuaregs, from Algeria in 1990 because of the drought of previous years. Next to that there is longstanding resentment among Tuaregs at being ruled by a government composed of a number of other ethnic groups. Libya admits that it military trained many Malian Tuaregs.) The Government states that there where about 50 people that died, but other sources talk about almost 600 people. 300 deaths per side. Forced eviction, Destruction of Houses and a lot of extra judicial executions followed this conflict.

(US State Dep. Report, in contrast to the Amnesty report doesn't mention Habib Ben Wahab who died in prison, nor the FE or D.)

1991: This year brought several changes. The 23 year old single party military dictatorship of President Moussa Traore was overthrown. This led to the establishment of a transitional government, which pledged to establish a multiparty democracy with free elections in 1992. There was intensive rioting, rebel activity and due to this a lot of $\mathrm{E}$, and some D. This happened primarily during the days of antigovernment rioting. Lt. Amadou Toumani TOURE became head of State during the transition period. The CTSP (Transitional Committee for the Salvation of the People) became the ruling body. The rebel activity that started in 1990 was still sporadic due to dissident rebel groups who didn't follow the accords signed with the previous regime. Both sides killed civilians and abducted people. About 39 civilians are reported to been killed by Tuareg rebels in at least 29 attacks. Military reprisals on civilians due to the killing of several soldiers and government supporter Mohamadoum Ag hamani and eight of his people in his house-hold.

Next to that the military's credibility was profoundly shaken when it used lethal force to put down the anti-regime demonstrations, even peaceful demonstrations. Although there were significant violations of Human Rights in 1991, especially those that were associated with the conflict in the North and the end of the Traore regime, the change in government in most respects improved the Human Rights situation. Political rights were greatly expanded and freedom of speech, press, assembly, and association increased significantly. The new constitution provides broad protection of Human Rights and civil liberties. Because of good media coverage of the events more Malians became aware of their rights and were less afraid to file complaints when these rights were violated. Next to that the transitional Government declared the judiciary independent of the legislative and executive power. The end of the year looked promising. One can see for instance the Freedom House figures moving from 19901992 from 'Not Free' into 'Free'. But the E this year consisted out of many different killings by the military (see footnotes). There were a lot of reprisals by the military to attacks towards them from rebels. And although the president repudiated the behaviour of the military, no one was arrested or tried. The Transitional Government however later arrested and charged a number of senior military officials who were believed to be responsible for issuing live ammunition to the troops. A wave of vigilante justice erupted after the overthrow of the previous regime. This ended in the end of 1991. But in the wake of massive jailbreaks, lack of confidence in the security system, mobs in Bamako and other cities hunted down about 15 suspected thieves and captured and killed them. However, in several cases, special police units rescued threatened individuals and treated them in accordance with the law.

1992: Mali became one of Africa's newest democracies in 1992. President Alpha Oumar Konare took office after a 14-month transition period. They ratified the new Constitution, 21 political parties emerged in the elections. There still is insurgency in the north that affects the country because of dissidents to the National Peace pact of 1991. Halfway the year hostilities reduced through the implementation by the Government of the National peace Pact, but the peace remained uneasy. Although there were extra judicial killings and violations of human rights because of the rebellion in the north of the country, the Government kept on the right track to improve human rights. A commission of inquiry to investigate the deaths on both sides was established, but end 1992 the commission has not done any work due to lack of consensus 
on the selection of foreign members. Still, the government shows action towards punishment, but none of the soldiers have been arrested or tried for these cases.

1993: Improved security situation relieved some domestic pressure, but allowed other problems to come out. Violent student demonstrations over government efforts to restrict scholarships in April forced the resignation of the first government of the Third Republic. The President tried to solve these problems consensually by incorporating several former opposition political parties into the second Government. Mali continues to be a myriad of economic problems including a sagging economy, a huge national debt, dependency on international donors, inadequate government revenues and other related problems. There were human rights abuses notably due to Governments inability to process the large backlog of judicial cases in accordance with the law. Resulting in people languishing in prison for several years awaiting trail. The Commission of inquiry that was supposed to be set up to investigate the extra judicial killings by the Military, had not been created by year's end. Moussa Traero, overthrown in 1991, remained in prison. He was held responsible for the deaths of over a hundred people during the demonstrations that led to the overthrow. Amnesty report states that he and three high functionaries got the death penalty for this.

1994: The new Prime Minister Ibrahim Boubacar Keita is heading the new Government. Violent student demonstrations flared up in February against government restrictions on financial aid, the same issue that had forced the resignation of the first government in 1993. The Government and students resolved their differences. Maur and Tuareg rebels and bandits in the north increased their attacks on civilian targets. They killed several civilians. On one instance in July they killed an estimated 40. These attacks led to reprisals. Estimated 300, mostly civilians, were killed. There is a lack of discipline among the security forces. They have committed extra judicial killings. There were human rights abuses notably due to Governments inability to process the large backlog of judicial cases in accordance with the law. Resulting in people languishing in prison for several years awaiting trail.

1995: Keita is still heading the constitutional democracy. In January the government reached agreement with the majority of Tuarg and Muar rebels in the north. Thus ending several years of rebellion. All parties held to the agreement. No reports of extra judicial killings according to the State Dep. Report, where AI states that there were at least 14 extra judicial killings. Mali continues to have large economic problems due to its dependency on foreign assistance, lack of industrial sector and the already mentioned problems. Female genital Mutilation is still common. No proposed legislation by Government, but support to educational efforts.

1996: Mali remains poor. It is still very dependent on adequate rainfall for it's economic wellbeing. A literacy rate of only $23 \%$ and a high population growth rate, also contribute to Mali's poverty. There were no developments in the killing of the Swiss Cooperation Mission Director. No attempts were made to expedite the case.

1997: Head of State, president Alpha Oumar Konare, was re-elected to a second 5 year term. Keita was reappointed as prime Minister. Election related violence resulted in the deaths of four persons. A bomb exploded in may in a crowded Bamako market on the day of the presidential elections, killing a young street vendor and wounding several others. In July persons shot into a group of voters in front of a polling station, killing 2 and wounding several others. In August a mob beat a police officer to death in Bamako outside an opposition party meeting.

1998: A collective of 18 opposition parties that boycotted the presidential elections in 1997 also boycotted the June municipal elections. Members of the security forces were responsible for a few human rights violations. The Justice minister initiated an overall review of prison conditions and in December confirmed that poor prison conditions persist. There was an incident of mob violence against Christian missionaries that resulted in several injuries and significant property damage. In another incident traditionalist Muslims killed a judge who had detained some of the sect's members. Amnesty International remains reporting that there are incidents of torture.

1999: Mali is now implementing still the decentralisation following local elections. It instituted far reaching administrative reforms during this year. There were two violent incidents 
between Fulani herders and Sarakole farmers in the western region of Kayes over natural resource management. Negotiations brought peace.

2000: This year Mali kept working on the implementation of a decentralised government. Children were still trafficked, put into forced Labour and Child Labour.

2001: Idem 2000.

2002: Idem 2000. Mali keeps heavily depending on donor countries, good rainfalls, FGM is still practised with young girls (almost 95\%), there is minimal foreign investment.

${ }^{1}$ Probably some form of child labour because of the fact that the report states that Children in rural areas join the family farming work force at a much younger age then the minimum age of 14 years (or 12 years with consent of the parent's)

${ }^{2}$ Probably some Forced Child labour because the report mentions that there are some reports from Mali that a form of traditional slavery is still practised in some isolated parts of the country.

${ }^{3}$ Report mentions abuse of detainees and although the infamous 'Taodenit'-prison, that caused a large number of deaths, is closed since 1988, there still is are harsh prison conditions that are characterized by inadequate medical facilities and food supplies.

${ }^{4}$ Good rainfalls for the second year in a row have increased agricultural production and permitted some export of grains. However, malnutrition, poor food distribution systems remain persistent problems.

5 Probably some form of child labour because of the fact that the report states that Children in rural areas join the family farming work force at a much younger age then the minimum age of 14 years (or 12 years with consent of the parent's)

${ }^{6}$ Probably some Forced Child labour because the report mentions that there are some reports from Mali that a form of traditional slavery is still practised in some isolated parts of the country.

${ }^{7}$ Numerous credible reports stated that as many as 29 persons were summarily executed. Government denied, but there were sufficient number of reports and enough credible to warrant an independent investigation, which the government refused.

${ }^{8}$ There are still are harsh prison conditions that are characterized by inadequate medical facilities and food supplies.

${ }^{9}$ Credible reports suspected Tuareg dissidents were tortured during interrogation.

${ }^{10}$ Probably some form of Child labour because of the fact that the report states that Children in rural areas join the family farming work force at a much younger age then the minimum age of 14 years (or 12 years with consent of the parent's)

${ }^{11}$ Probably some Forced Child labour because the report mentions that there are some reports from Mali that a form of traditional slavery is still practised in some isolated parts of the country. Next to that there still is some debt slavery in salt mining in the North where also children are probably active. Important to note is that since the change of the regime many of those treated as slaves have refused to continue working under those conditions.

${ }^{12}$ This E consists out of several actions by he military. Credible reports of extra judicial killings by the military. These were numerous accounts by security forces using excessive force in putting down anti-regime demonstrations in Bamako and with dealing with the rebellion in the North. The security forces in Bamako and other cities opened fire on demonstrators, killing 216 and wounding 717. Some killings were done when demonstrators were looting, many others occurred during peaceful demonstrations. In addition there are credible reports that 65 persons died when security forces set fire to a building into which demonstrators had fled. There were reprisals on Tuaregs and Maurs by the military as a response to rebellion activities. These consisted out of executing 10 Tuareg civilians, murdering leading Tuareg notables, executing 34 nomads in Lere, 15 nomads near Tonka. The number of deaths in the conflict seems difficult to estimate, but credible reports put total civilian Tuareg deaths at the hands of the military at around 70. Various rebel and bandit groups lost around 150 people.

${ }^{13}$ During the time of the Transitional Government things have changed to the better (e.g. the ICRC conducted seminars for prison officials on the treatment of officials and they responded and acted upon these seminars in a positive way), but fact remains that many prisons outside the capital still have very harsh prison conditions due to a lack of basic needs like medical facilities and food supplies.

${ }^{14}$ The new constitution prohibits torture and the Transitional Government made strides to end this physical abuse of suspects, which sometimes occurred during police interrogation. Next to that people became more aware of their rights due to the good media coverage and were not afraid to complain more. But fact remains that there are strides to end it, but it hasn't ended yet. No figures are given, but it is probable that there is still some torture.

${ }^{15}$ Many nomads lost cattle herds and commercial enterprises were destroyed. They were destroyed by the military, but also by the rebels. There are no statistics to show who did what in what amount.

${ }^{16}$ Several instances by security forces in the north in reprisal of rebel attacks against unarmed Tuaregs (over one hundred say credible reports) and Maurs (no real estimation, only reports on 24 people executed in a raid other reports not stating numbers).

17 The government took action when it heard about Tuareg allegations of mistreatment of prisoners by sending a high-level team to investigate. Prison facilities are more adequate, and the Government takes action, but still, conditions are still harsh, medical facilities inadequate and food supplies short.

${ }^{18}$ Many nomads lost cattle herds and commercial enterprises were destroyed. They were destroyed by the military, but also by the rebels. There are no statistics to show who did what in what amount 
${ }^{19}$ Probably some form of child labour because of the fact that the report states that Children in rural areas join the family farming work force at a much younger age then the minimum age of 14 years (or 12 years with consent of the parent's)

${ }^{20}$ Probably some Forced Child labour because the report mentions that there are some reports from Mali that a form of traditional slavery is still practised in some isolated parts of the country.

${ }^{21}$ Allegedly torturing of 2 men who were held in military custody.

${ }^{22}$ Soldiers from the government raided camps and destroyed properties and the camp itself.

${ }^{23}$ Soldiers of the government forced people in camps at the boarder of Algeria to evict their camps and they chased them (under whom elderly people and children) into the desert, where they died from thurst.

${ }^{24}$ Political prisoners are held under poor prison conditions.

${ }^{25}$ Habib Ben Wahab was tortured in the police station.

${ }^{26}$ Habib Ben Wahab died because of the physical abuse and torture. Next to that more then 50 people where extrajudicialy executed by the government. The people that where evicted from their camps and where chased into the desert should also be taken into account with these extra judicial killings.

${ }^{27}$ During demonstrations 200 people were killed by security forces (many shot in the back), an unspecified number of Tuareg and Maur were killed by security forces in the North, an additional 80 students were killed in March during demonstartions by security forces, In mai 23 Maur were killed and 25 Tuareg (these numbers were specified), in july between 15-50 Tuareg were killed in their civilian vehicles when they were shot at by military forces, in nov/dec more then 20 Tuaregs were killed in a retaliation by the military.

${ }^{28}$ Reported torturing of prisoners in detention and even children under the age of 12 . The detainees were severely beaten, put in the sun without water and all of them packed into 1 cel. Men, women and children.

${ }^{29}$ All detainees were put into one cell without sanitairy or washing possibilities.

${ }^{30}$ All detainees were put into one cell without sanitairy or washing possibilities, also the children.

${ }^{31}$ Around 10 or more Tuareg were killed by the military. In april-september around 60 Tuaregs were killed by security forces. In may around 20 Tuaegs and Maur cattle keepers were killed by security forces as a retailliation.

${ }^{32}$ According to some reports prisinors were allegedly beaten to give a confession.

${ }_{33}^{33}$ Juvenile offenders are generally held in the same prison as adult offenders.

${ }^{34}$ Three Tuareg refugees were killed. Report is not yet released. Government states they were shot in a firefight because of an earlier attack on a transport convoy. Probably they were extrajudicialy killed.

${ }^{35}$ Only $20 \%$ of children have access to basic education. Government's resources are insufficient to meet the basic health care and education needs of Malian Children.

${ }^{36}$ Probably some form of child labour because of the fact that the report states that Children in rural areas join the family farming work force at a much younger age then the minimum age of 14 years (or 12 years with consent of the parent's)

${ }^{37}$ Probably some Forced Child labour because the report mentions that there are some reports from Mali that a form of traditional slavery is still practised in some isolated parts of the country.

${ }^{38}$ Security forces committed an undetermined number of extra judicial killings of Tuaregs and Maurs in June, July and August. 50 more were killed by security forces. In April the military killed 4 and wounded 12. In October reports of a military patrol that killed the Swiss Cooperation Director and two Malian colleges. Inquiries were made, reports apparently written by the Government, but nothing concrete has come out of it. No prosecution.

${ }^{39}$ Many prisons outside the capital still have very harsh prison conditions due to a lack of basic needs like medical facilities and food supplies. Next to that the prisons are overcrowded.

${ }^{40}$ Probably some form of child labour because of the fact that the report states that Children in rural areas join the family farming work force at a much younger age then the minimum age of 14 years (or 12 years with consent of the parent's)

${ }^{41}$ Probably some Forced Child labour because the report mentions that there are some reports from Mali that a form of traditional slavery is still practised in some isolated parts of the country.

${ }^{42}$ Only one in five children have access to basic education.

${ }^{43}$ Juvenile offenders are generally held in the same prison as adult offenders.

${ }^{44}$ Many prisons still have very harsh prison conditions due to a lack of basic needs like medical facilities and food supplies. Next to that the prisons are overcrowded.

45 Juvenile offenders are generally held in the same prison as adult offenders.

${ }^{46}$ Only one in five children have access to basic education.

${ }^{47}$ Probably some form of child labour because of the fact that the report states that Children in rural areas join the family farming work force at a much younger age then the minimum age of 14 years (or 12 years with consent of the parent's)

${ }^{48}$ Probably some Forced Child labour because the report mentions that there are some reports from Mali that a form of traditional slavery is still practised in some isolated parts of the country.

${ }^{49}$ Many prisons still have very harsh prison conditions due to a lack of basic needs like medical facilities and food supplies. Next to that the prisons are overcrowded. They remain under the minimum international standards. ICRC visits and worked to improve their conditions.

${ }^{50}$ Juvenile offenders are generally held in the same prison as adult offenders. In Bamako juvenile offenders are usually held in the same prison as adult offenders, but in separate cells. In regional prisons outside the capital men and women are housed in the same building but separate cells. Children here are sharing cells with the adult prisoners of the same sex. 
${ }^{51}$ Only one in five children have access to basic education.

${ }^{52}$ Probably some form of child labour because of the fact that the report states that Children in rural areas join the family farming work force at a much younger age then the minimum age of 14 years (or 12 years with consent of the parent's)

${ }^{53}$ Probably some Forced Child labour because the report mentions that there are some reports from Mali that a form of traditional slavery is still practised in some isolated parts of the country. This traditional enslavement persists. Especially to all the people of the Bellah ethnic group. Although people of the Bellah group get some wages in the salt mines, these wages are meager.

${ }^{54}$ Amnesty report claims there were 20 extra judicial killings.

${ }^{55}$ Amnesty report claims that at least 170 unarmed civilians were killed by government forces as reprisal for attacks by armed political groups.

${ }^{56}$ Amnesty report states that at least 14 people were extrajudicialy killed.

${ }^{57}$ Journalists and opposition party sympatisants were arrested and beaten with wooden sticks and systematically tortured, in the presence of high officials of the leading party, during detention.

${ }^{58}$ Many prisons still have very harsh prison conditions due to a lack of basic needs like medical facilities and food supplies. Next to that the prisons are overcrowded. They remain under the minimum international standards. ICRC visits and worked to improve their conditions.

${ }^{59}$ Juvenile offenders are generally held in the same prison as adult offenders. In Bamako juvenile offenders are usually held in the same prison as adult offenders, but in separate cells. In regional prisons outside the capital men and women are housed in the same building but separate cells. Children here are sharing cells with the adult prisoners of the same sex.

${ }^{60}$ Only one in two children receives basic education.

${ }^{61}$ Child labour because of the fact that the report states that Children in rural areas join the family farming work force at a much younger age then the minimum age of 14 years (or 12 years with consent of the parent's) Labour code adopted that has specific policies pertaining child labour. It enforces the protection of children through labour inspectors, but resources are limited. Regulations are often ignored in practice and Labour Code has no effect on the vast number of children in the rural areas.

${ }^{62}$ Probably some Forced Child labour because the report mentions that there are some reports from Mali that a form of traditional slavery is still practised in some isolated parts of the country. This traditional enslavement persists. Especially to all the people of the Bellah ethnic group. Although people of the Bellah group get some wages in the salt mines, these wages are meager.

${ }^{63}$ State department mentions that Amnesty International reports accuse the Government of instances of Torture. This AI report was published on 01/11/1997 and dealt with the basic liberties at risc, including an allegation of torture. This report is not a country year report!

${ }^{64}$ Many prisons still have very harsh prison conditions due to a lack of basic needs like medical facilities and food supplies. Next to that the prisons are overcrowded. They remain under the minimum international standards. ICRC visits and worked to improve their conditions.

${ }^{65}$ Juvenile offenders are generally held in the same prison as adult offenders. In Bamako juvenile offenders are usually held in the same prison as adult offenders, but in separate cells. In regional prisons outside the capital men and women are housed in the same building but separate cells. Children here are sharing cells with the adult prisoners of the same sex.

${ }^{66}$ Only one in two children receive basic education.

${ }^{67}$ Child labour because of the fact that the report states that Children in rural areas join the family farming work force at a much younger age then the minimum age of 14 years (or 12 years with consent of the parent's) Labour code adopted that has specific policies pertaining child labour. It enforces the protection of children through labour inspectors, but resources are limited. Regulations are often ignored in practice and Labour Code has no effect on the vast number of children in the rural areas.

${ }^{68}$ Probably some Forced Child labour because the report mentions that there are some reports from Mali that a form of traditional slavery is still practised in some isolated parts of the country. This traditional enslavement persists. Especially to all the people of the Bellah ethnic group. Although people of the Bellah group get some wages in the salt mines, these wages are meager. But now also connected with the TL.

${ }^{69}$ State department mentions that Amnesty International reports accuse the Government of instances of Torture. This AI report was published on 01/10/1998 and specifically dealt with torture and the allegation that there were instances of torture in mali also that year. This report is not an AI country year report!

${ }^{70}$ Some Malian children were sold into forced labour in Cote D'Ivoire.

${ }^{71}$ Gendarmes, military veterans and local hunters killed 11 members of a traditional Muslim sect in a skirmish following the jailbreak. Not clear if/how much this can be seen as purely extra judicial killings.

${ }^{72}$ Many prisons still have very harsh prison conditions due to a lack of basic needs like medical facilities and food supplies. Next to that the prisons are overcrowded. They remain under the minimum international standards. ICRC visits and worked to improve their conditions. Minister confirms the persisting poor prison conditions, but they are improving.

${ }^{73}$ Juvenile offenders are generally held in the same prison as adult offenders. In Bamako juvenile offenders are usually held in the same prison as adult offenders, but in separate cells. In regional prisons outside the capital men and women are housed in the same building but separate cells. Children here are sharing cells with the adult prisoners of the same sex. 
${ }^{74}$ Only one in two children receive basic education.

${ }^{75}$ Child labour because of the fact that the report states that Children in rural areas join the family farming work force at a much younger age then the minimum age of 14 years (or 12 years with consent of the parent's) Labour code adopted that has specific policies pertaining child labour. It enforces the protection of children through labour inspectors, but resources are limited. Regulations are often ignored in practice and Labour Code has no effect on the vast number of children in the rural areas.

${ }^{76}$ Probably some Forced Child labour because the report mentions that there are some reports from Mali that a form of traditional slavery is still practised in some isolated parts of the country. This traditional enslavement persists. Especially to all the people of the Bellah ethnic group. Although people of the Bellah group get some wages in the salt mines, these wages are meager. But now also connected with the TL.

${ }^{77}$ Some Malian children were sold into forced labour in Cote D'Ivoire.

${ }_{78}^{78}$ According to media reports the children that are forced to work are often abused physically

${ }^{79}$ Many prisons still have very harsh prison conditions due to a lack of basic needs like medical facilities and food supplies. Next to that the prisons are overcrowded. They remain under the minimum international standards. ICRC visits and worked to improve their conditions. Justice Minister confirms the persisting poor prison conditions, but they are improving. Training programs and extensive discussions try to improve the prison conditions.

${ }^{80}$ Juvenile offenders are generally held in the same prison as adult offenders. In Bamako juvenile offenders are usually held in the same prison as adult offenders, but in separate cells. In regional prisons outside the capital men and women are housed in the same building but separate cells. Children here are sharing cells with the adult prisoners of the same sex. No reports of juveniles being abused by other inmates or guards.

${ }^{81}$ Only 50 percent of children receive basic education.

${ }^{82}$ Child labour because of the fact that the report states that Children in rural areas join the family farming work force at a much younger age then the minimum age of 14 years (or 12 years with consent of the parent's) Labour code adopted that has specific policies pertaining child labour. It enforces the protection of children through labour inspectors, but resources are limited. Regulations are often ignored in practice and Labour Code has no effect on the vast number of children in the rural areas.

${ }^{83}$ Probably some Forced Child labour because the report mentions that there are some reports from Mali that a form of traditional slavery is still practised in some isolated parts of the country. This traditional enslavement persists. Especially to all the people of the Bella ethnic group. Although people of the Bellah group get some wages in the salt mines, these wages are meager. But now also connected with the TL.

${ }^{84}$ State department mentions that there were reports that accuse the Government of two instances of Torture by security forces in order to extract confessions, after this hey were killed in custody. These reports do not originate from Amnesty International. The source of the reports is not mentioned.

${ }^{85}$ Security forces tortured and killed two suspects in custody according to reports.

${ }^{86}$ Some Malian children were sold into forced labour in Cote D'Ivoire. An estimated 15,000 children between 9 and 12 have been sold into forced labour on the cotton, coffee and cocoa plantages. Some 50 children were returned to their families.

${ }^{87}$ According to media reports the children that are forced to work are often abused physically.

${ }^{88}$ Many prisons still have very harsh prison conditions due to a lack of basic needs like medical facilities and food supplies. Next to that the prisons are overcrowded. They remain under the minimum international standards. ICRC visits and worked to improve their conditions. Justice Minister confirms the persisting poor prison conditions, but they are improving. Training programs and extensive discussions try to improve the prison conditions.

${ }^{89}$ Juvenile offenders are generally held in the same prison as adult offenders. In Bamako juvenile offenders are usually held in the same prison as adult offenders, but in separate cells. In regional prisons outside the capital men and women are housed in the same building but separate cells. Children here are sharing cells with the adult prisoners of the same sex. No reports of juveniles being abused by other inmates or guards.

${ }_{90}$ Only 56 (46\% for girls) percent of children receives basic education.

${ }^{91}$ Child labour because of the fact that the report states that Children in rural areas join the family farming work force at a much younger age then the minimum age of 14 years (or 12 years with consent of the parent's) Labour code adopted that has specific policies pertaining child labour. It enforces the protection of children through labour inspectors, but resources are limited. Regulations are often ignored in practice and Labour Code has no effect on the vast number of children in the rural areas. The report now states clearly: Child Labour is a problem.

${ }^{92}$ Probably some Forced Child labour because the report mentions that there are some reports from Mali that a form of traditional slavery is still practised in some isolated parts of the country. This traditional enslavement persists. Especially to all the people of the Bellah ethnic group. Although people of the Bellah group get some wages in the salt mines, these wages are meager. But now also connected with the TL.

${ }^{93}$ Some Malian children were sold into forced labour in Cote D'Ivoire. An estimated 15,000 children between 9 and 12 have been sold into forced labour on the cotton, coffee and cocoa plantages. Some 300 children were returned to their families. This number is without the children that do not go through 'welcome-houses'.

${ }^{94}$ According to media reports the children that are forced to work are often abused physically.

${ }^{95}$ Many prisons still have very harsh prison conditions due to a lack of basic needs like medical facilities and food supplies. Next to that the prisons are overcrowded. They remain under the minimum international standards. ICRC visits and worked to improve their conditions. Justice Minister confirms the persisting poor prison conditions, but they are improving. Training programs and extensive discussions try to improve the prison conditions. 
${ }^{96}$ Juvenile offenders are generally held in the same prison as adult offenders. In Bamako juvenile offenders are usually held in the same prison as adult offenders, but in separate cells. In regional prisons outside the capital men and women are housed in the same building but separate cells. Children here are sharing cells with the adult prisoners of the same sex. No reports of juveniles being abused by other inmates or guards.

${ }_{97}$ Only 56 (46\% for girls) percent of children receives basic education. Large shortages of teachers and materials.

${ }^{98}$ Child labour because of the fact that the report states that Children in rural areas join the family farming work force at a much younger age then the minimum age of 14 years (or 12 years with consent of the parent's) Labour code adopted that has specific policies pertaining child labour. It enforces the protection of children through labour inspectors, but resources are limited. Regulations are often ignored in practice and Labour Code has no effect on the vast number of children in the rural areas. Next to that most street vendors are children as well. The report now states clearly: Child Labour is a problem.

${ }^{99}$ Probably some Forced Child labour because the report mentions that there are some reports from Mali that a form of traditional slavery is still practised in some isolated parts of the country. This traditional enslavement persists. Especially to all the people of the Bellah ethnic group. Although people of the Bellah group get some wages in the salt mines, these wages are meager. But now also connected with the TL.

${ }^{100}$ Some Malian children were sold into forced labour in Cote D'Ivoire. An estimated 15,000 children between 9 and 12 have been sold into forced labour on the cotton, coffee and cocoa plantages. No mention of returned children. 


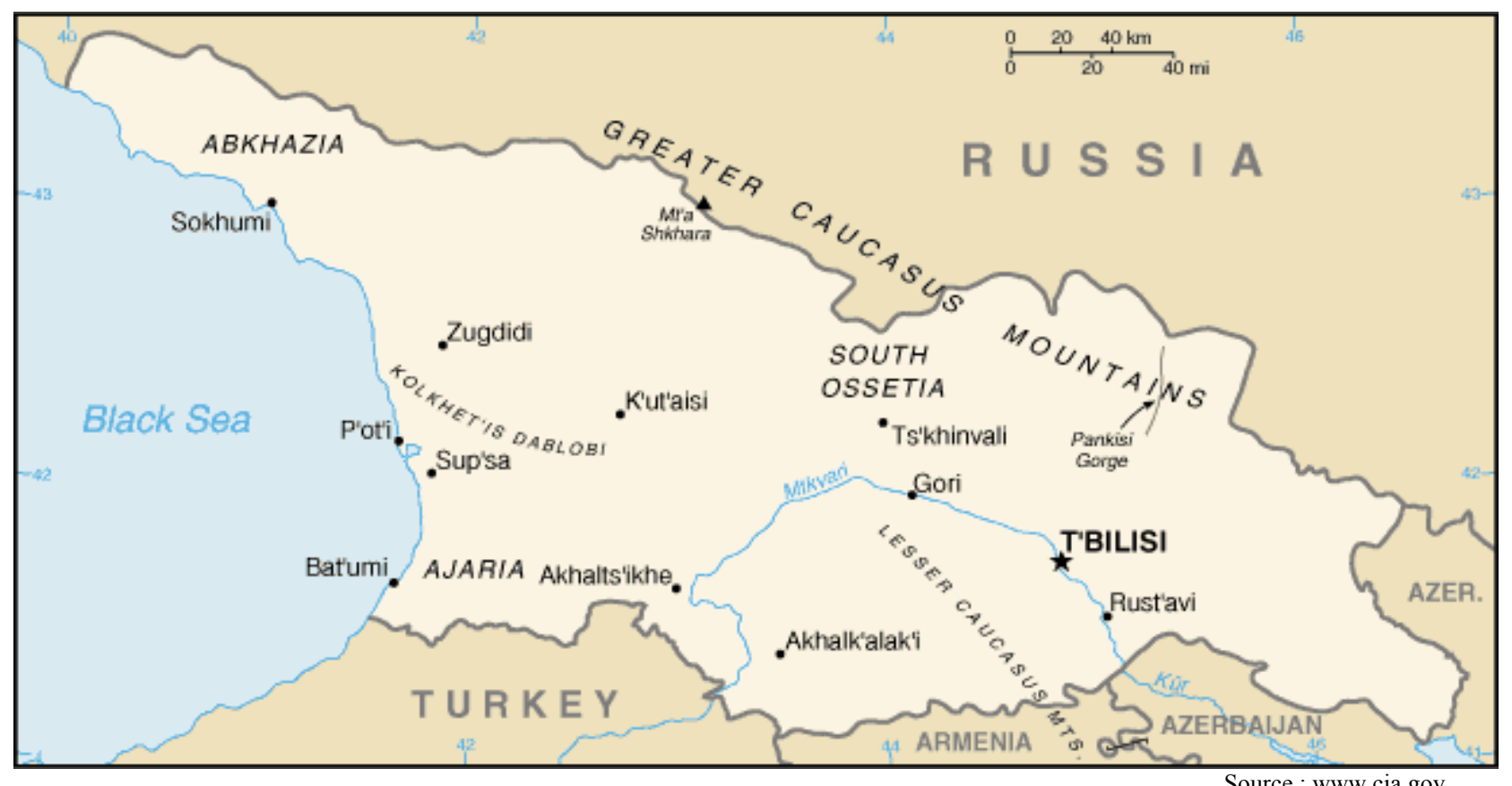

Source : www.cia.gov

GEORGIA:

(population: 4,934,413)

\begin{tabular}{|c|c|c|c|c|}
\hline $\begin{array}{c}\text { Political } \\
\text { Terrorscale }\end{array}$ & 1989 & $\mathbf{1 9 9 0}$ & $\mathbf{1 9 9 1}$ & $\mathbf{1 9 9 2}$ \\
\hline Conflict Level & & & & $4 / 2$ \\
\hline $\begin{array}{c}\text { Freedom } \\
\text { House }\end{array}$ & & & & $\begin{array}{c}\text { 3 low intensity } \\
\text { conflicts: Abkhazia } \\
\text { (a few hundred } \\
\text { killed); South } \\
\text { Ossetia; Zviadists } \\
\text { (between 100 to } \\
\text { several hundred } \\
\text { killed) }\end{array}$ \\
\hline $\begin{array}{c}\text { U.S. State } \\
\text { Department }\end{array}$ & & & $6 / 5 / \mathrm{NF}$ & $4 / 5 / \mathrm{PF}$ \\
\hline
\end{tabular}

\begin{tabular}{|c|c|c|c|c|}
\hline & 1993 & 1994 & 1995 & 1996 \\
\hline $\begin{array}{c}\text { Political } \\
\text { Terrorscale }\end{array}$ & $4 / 5$ & $2 / 4$ & $3 / 3$ & $2 / 3$ \\
\hline
\end{tabular}




\begin{tabular}{|c|c|c|c|c|}
\hline Conflict Level & $\begin{array}{c}2 \text { High intensity } \\
\text { conflicts (Abkhazia: } \\
\text { hundreds killed on } \\
\text { both sides; Zviadists: } \\
\text { violence erupted into } \\
\text { civil war no number } \\
\text { for casualties), } \\
\text { violent political } \\
\text { conflict (South } \\
\text { Ossetia: occasionnal } \\
\text { killings) }\end{array}$ & $\begin{array}{c}\text { Low intensity } \\
\text { conflict (Abkhazia: } \\
800 \text { hundred killed), } \\
\text { violent political } \\
\text { conflict (South } \\
\text { Ossetia: occasionnal } \\
\text { killings) }\end{array}$ & $\begin{array}{c}\text { Low intensity } \\
\text { conflict (Abkhazia), } \\
\text { violent political } \\
\text { conflict (South } \\
\text { Ossetia) }\end{array}$ & $\begin{array}{l}2 \text { violent political } \\
\text { conflicts (Abkhazia } \\
\text { and South Ossetia) }\end{array}$ \\
\hline $\begin{array}{l}\text { Freedom } \\
\text { House }\end{array}$ & $5 / 5 / \mathrm{PF}$ & $5 / 5 / \mathrm{PF}$ & $4 / 5 / \mathrm{PF}$ & $4 / 4 / \mathrm{PF}$ \\
\hline $\begin{array}{c}\text { U.S. State } \\
\text { Department }\end{array}$ & $\mathrm{e}^{5}, \mathrm{P}^{6}, \mathrm{~T}^{7}, \mathrm{D}, \mathrm{FE}^{8}, \mathrm{R}^{9}$ & $\mathrm{e}^{10}, \mathrm{P}^{11}, \mathrm{t}^{12}, \mathrm{R}^{13}$ & $\mathrm{E}^{14}, \mathrm{P}^{15}, \mathrm{t}_{\mathrm{R}^{16}}^{16}, \mathrm{AE}^{17}, \mathrm{~S}^{18}$ & $\mathrm{e}^{20}, \mathrm{P}^{21}, \underset{\mathrm{R}^{25}}{\mathrm{t}^{22}}, \mathrm{AE}^{23}, \mathrm{~S}^{24}$, \\
\hline & 1997 & 1998 & 1999 & 2000 \\
\hline $\begin{array}{c}\text { Political } \\
\text { Terrorscale }\end{array}$ & 3 & 3 & & 2 \\
\hline Conflict Level & $\begin{array}{l}\text { Violent political } \\
\text { conflict (South } \\
\text { Ossetia) and Low } \\
\text { intensity conflict } \\
\text { (Abkhazia: increase } \\
\text { in partisan violence) }\end{array}$ & $\begin{array}{l}\text { Violent political } \\
\text { conflict (South } \\
\text { Ossetia) and Low } \\
\text { intensity conflict } \\
\text { (Abkhazia: at least } \\
239 \text { killed) }\end{array}$ & $\begin{array}{l}2 \text { violent political } \\
\text { conflicts (Abkhazia: } \\
\text { some violent } \\
\text { incidents, but } \\
\text { decrease from 1998; } \\
\text { South Ossetia) }\end{array}$ & $\begin{array}{l}2 \text { Violent Political } \\
\text { Conflicts (Abkhazia: } \\
\text { some violent } \\
\text { incidents, but } \\
\text { decrease from 1999; } \\
\text { South Ossetia) }\end{array}$ \\
\hline $\begin{array}{l}\text { Freedom } \\
\text { House }\end{array}$ & $3 / 4 / \mathrm{PF}$ & $3 / 4 / \mathrm{PF}$ & $3 / 4 / \mathrm{PF}$ & $4 / 4 / \mathrm{PF}$ \\
\hline $\begin{array}{c}\text { U.S. State } \\
\text { Department }\end{array}$ & $\begin{array}{l}\mathrm{e}^{26}, \mathrm{P}^{27}, \mathrm{t}^{28}, \mathrm{AE}^{29}, \\
\mathrm{CP}^{30}, \mathrm{~S}^{31}, \mathrm{R}^{32},\end{array}$ & $\begin{array}{c}\mathrm{e}^{33}, \mathrm{P}^{34} \mathrm{t}^{35}, \mathrm{AE}^{36} \\
\mathrm{CP}^{37}, \mathrm{~S}^{38}, \mathrm{D}^{39}, \mathrm{FE}^{40} \\
\mathrm{R}^{41}\end{array}$ & $\begin{array}{c}\mathrm{e}^{42}, \mathrm{P}^{43}, \mathrm{t}^{44}, \mathrm{AE}^{45} \\
\mathrm{CP}^{46}, \mathrm{~S}^{47}, \mathrm{R}^{48}\end{array}$ & $\begin{array}{l}\mathrm{e}^{49}, \mathrm{P}^{50}, \mathrm{~T}^{51}, \mathrm{AE}^{52} \\
\mathrm{CP}^{33}, \mathrm{PC}^{54}, \mathrm{~S}^{55}, \mathrm{R}^{56}\end{array}$ \\
\hline
\end{tabular}

\begin{tabular}{|c|c|c|}
\hline $\begin{array}{c}\text { Political } \\
\text { Terrorscale }\end{array}$ & $\mathbf{2 0 0 1}$ & $\mathbf{2 0 0 2}$ \\
\hline Conflict Level & $\begin{array}{c}\text { 2 Violent Political } \\
\text { Conflicts (Abkhazia, } \\
\text { violence erupted in } \\
\text { October: 81 killed; } \\
\text { and South Ossetia) }\end{array}$ & $\begin{array}{c}\text { 2 violent political } \\
\text { conflicts (Abkhazia } \\
\text { and South Ossetia) }\end{array}$ \\
\hline $\begin{array}{c}\text { Freedom } \\
\text { House }\end{array}$ & $4 / 4 / \mathrm{PF}$ & $4 / 4 / \mathrm{PF}$ \\
\hline
\end{tabular}




\section{U.S. State

\section{Working conditions:}

1993: Although workers in hazardous conditions may obtain higher wages, or may refuse the work, these provisions are considered inadequate for worker well-being.

1994: Workers in hazardous conditions may obtain higher wages, or may refuse the work if it endangers their life.

1995: Workers in hazardous conditions may obtain higher wages, or may refuse the work if it endangers their life.

1996: Workers in hazardous conditions may obtain higher wages, or may refuse the work if it endangers their life.

1997: Workers in hazardous conditions may obtain higher wages, or may refuse the work if it endangers their life.

1998: Workers in hazardous conditions may obtain higher wages, or may refuse the work if it endangers their life.

1999: Workers in hazardous conditions may obtain higher wages, or may refuse the work if it endangers their life.

2000: Workers in hazardous conditions may obtain higher wages, or may refuse the work if it endangers their life, without loosing their job. Old Soviet Labour codes are still in force. A new labour code has not been adopted.

2001: Workers in hazardous conditions may obtain higher wages, or may refuse the work if it endangers their life, without loosing their job.

2002: Workers in hazardous conditions may obtain higher wages, or may refuse the work if it endangers their life, without loosing their job.

\section{Brief historical/political overview}

General comment: The stability of the country is continuously undermined, by great refugee flows from South Ossetia and Abkhazia (and later on from Chechnya), by conflicts in South Ossetia, Abkhazia and ongoing violence from and directed against supporters of the President that was ousted after a military coup in 1992: Zviad Gamsakhurdia, and by the fact Ajara is an area which operates quasi-autonomously, but has an undefined status. In Abkhazia, South Ossetia and Ajara the government has no effective control.

1992: On April 9, 1991 Georgia declared its independence. Popularly elected President Zviad Gamsakhurdia was overthrown in January 1992 as his increasingly dictatorial rule led to an armed insurgency. A military council of insurrection leaders took control and imposed a state of emergency and a curfew in Tblisi and certain other areas. In April Eduard Shevarnadze was invited to return to Georgia by the Council. He tried to establish a responsible government. He set up the State Council, a civilian legislative body, and he was elected Chairman of its fourmember executive Presidium. Acknowledging that this Government lacked legitimacy, Shevarnadze promised elections. The country remained wracked separatist conflicts in South Ossetia and Abkhazia, and violence linked to supporters of the ousted president (Zviadists). The ex-president even attempted to seize power, but the coup failed. The conflict in South Ossetia led to a largely successful cease-fire during the year. The conflict in Abkhazia sharpened somewhat as the Abkhazian minority in the regional parliament voted to restore the 1925 Abkhazian Constitution which acknowledges Abkhazia to be a separate Union Republic. 
The Georgian State Council directly declared the resolution to be null and void. On August 14 Zviadists took eleven senior Georgian officials hostage including the Minister of Interior. A large armed force was sent to rescue the hostages and secure railroads in Abkhazia. In Abkhazia they met fierce resistance from Abkhazian guards and Caucasian "volunteers". The violence claimed at least a few hundred lives and is ongoing. On October 11 there were successful elections in 75 of 84 districts. Parliament was elected and Shevarnadze was voted in without a challenge. Despite some irregularities the vote was considered fair. By the end of the year there was still no constitution, but a temporary law was passed allocating many powers to the President. Parliament also became a strong entity.

1993: In August-September a confrontation between Shevrdnadze and the Parliament over the Head of State's right to confirm ministerial appointees, resulted in the resignation of Shevardnadze, only for him to return after 24 hours with the guarantee that the Parliament declare the state of emergency and suspend its own activities for 2 months. The conflict in Abkhazia continued. After unequal implementation of a cease fire, the military advantage gained by the separatists was used to launch an assault. The capital of Abkhazia was captured and the Abkhazian forces committed many human rights abuses. The conflict with Zviadists also continued. The Zviadists captured a number of towns, but Georgian forces regained them within 1993.

1994: A U.N. brokered cease fire in Abkhazia was agreed upon. Ethnic cleansing in Abkhazia continued. Hundreds of ethnic Georgians and other non-Abkhaz were tortured, raped, killed, expelled and imprisoned. A CIS peacekeeping force was deployed.

1995: On August 24, 1995 a new constitution was adopted by Parliament providing for a unicameral legislature, an independent judiciary, and an executive branch which reports to the President. Moreover the Constitution proscribes the creation of an Office of Human Rights Defender. The Government complied with this. On November 5 Shevardnadze was elected President and a new Parliament was elected in elections considered "consistent with democratic norms." The Constitution entered into force on November 18. Internal conflicts in Abkhazia and South Ossetia remained unresolved. Although there were no hostilities in South Ossetia the government has no effective control over the territory. On August 29 an attempted assassination of then Chairman Shevardnadze failed. Abkhazians commit a great number of human rights abuses in a bid to ethnically cleanse Abkhazia.

1996: Internal conflicts in South Ossetia and Abkhazia remain unresolved. Abkhaz separatists continue to commit gross human rights abuses. The Office of the Human rights defender created in 1995 is not yet functioning.

1997: Although cease fires were in force both internal conflicts, in South Ossetia and Abkhazia, remained unresolved. There were no large-scale armed hostilities in both areas, but partisan warfare in Abkhazia increased. "Citizen awareness of democratic values, and growth of civil society provided some check on the excesses of law enforcement agencies." New law on the Courts was aimed at bringing greater judicial independence. The place of the Human Rights defender (the ombudsman) was filled, but the office remained inoperative.

1998: Both internal conflicts remained unresolved. In Abkhazia (the Gali region) violence broke out in May resulting in 239 casualties. Abkhaz forces burned an estimated 50\% of homes in some areas, and 40,000 of the residents of Gali who had fled their homes have not yet returned. The Government delayed implementation of the new Criminal Procedures Code, passed in November 1997, until May 1999. In February there was an unsuccessful assassination attempt on President Shevardnadze. The Ombudsman started his work and focussed social and economic rights and not so much on abuse by law enforcement agencies. First local elections were held in November. The elections were "not perfect", but constituted a "very positive step in Georgia's nascent election reform movement".

1999: On October 31 parliamentary elections are held, characterised by the OSCE as a "step forward Georgia's compliance with OSCE commitments". Internal conflicts in South Ossetia and Abkhazia remained unresolved. Cease fires are in effect in both areas, although sporadic violence occurs in Abkhazia. A new Criminal Code was passed in June. The Criminal Procedures Code underwent substantial amendments following complaints by security forces. Many of the original powers of the security forces were reinstalled. In April Georgia gained 
accession to the Council of Europe. The war in Chechnya affected the situation in Georgia. In August Russian warplanes dropped cluster bombs on the Georgian village of Zemo Omalo, wounding three persons.

2000: President Shevardnadze is elected for a second term. The elections were marred by serious irregularities. The conflicts in South Ossetia and Abkhazia remained unresolved. The human rights situation worsened.

2001: The conflicts in South Ossetia and Abkhazia remained unresolved. Following clashes in October the Georgian government passed a non binding resolution to remove CIS (Russian) peacekeeping forces from Abkhazia. The human rights situation remained poor and worsened in some areas. There were some 5,000 refugees from Chechnya.

2002: Local and municipal elections were held in June. The elections were marred by irregularities. Observers criticised the elections "citing hasty and poor organization by authorities and inaccurate voter registers." Human rights record remained poor, but improved in certain areas. The conflicts in Abkhazia and South Ossetia remained unresolved. There were some 3,900 refugees from Chechnya. In Abkhazia, the Abkhazian Ministry of Education announced a ruling prohibiting the instruction in Georgian in schools in Abkhaz-controlled territory (as this is a decision by a non-recognised entity in Georgia it will not be marked with "AE" in the table, just like abuses by Abkhazian forces have not been marked in the table, but mentioned in the "brief political/historical overview").

\footnotetext{
${ }^{1}$ Following a directive by Secretary of State Warren Christopher some changes in reporting were made as of the 1993 report. The changes include a stronger emphasis on prison conditions and a new section on "discrimination based on race, sex, religion, disability, language or social status. This new section also includes a paragraph on discrimination against children.

${ }^{2}$ At least one politically motivated extrajudicial execution. There are believed to be several others (the report names 10 possible cases). In the conflict in Abkhazia there were reports (credible reports) of a number of summary executions.

${ }^{3}$ Police beatings were widespread and routine. The beatings of teenage boys were a disturbing pattern. Some of the beatings were severe thus placing it under the definition of torture.

${ }^{4}$ There remains a problem regarding the Georgian's apparent refusal to allow some 200,000 Muslim now living in central Asian Republics and parts of Russia, resident of the Meshketi region, deported from Georgia in 1999 by Stalin, to return to Georgia. In South Ossetia, Georgian refugees were still to afraid to return.

${ }^{5}$ Some prisoners were killed by Georgian military and paramilitary units.

${ }^{6}$ Because of the decline in the economic and political situation prisoners were given Spartan meals. Conditions overall were extremely primitive, with no bathing facilities, no place to lie down, and no toilet.

${ }^{7}$ There are many examples of severe beatings.

${ }^{8}$ The conflict in Abkhazia forced many civilians to. Moreover there were credible reports of ethnic cleansing in which civilians were forced out of their houses.

${ }^{9}$ There remains a problem regarding the Georgian's apparent refusal to allow some 200,000 Muslim now living in central Asian Republics and parts of Russia, resident of the Meshketi region, deported from Georgia in 1999 by Stalin, to return to Georgia. In South Ossetia, Georgian refugees were still to afraid to return. Moreover those who fled the conflict in Abkhazia have not been allowed to return.

${ }^{10}$ It is difficult to discern exact figures from the report. The report notes it is very difficult to make a distinction between political killings or criminal killings. The report also notes a report by the State Committee on Human Rights and Interethnic Relations (SCHR) in which it is stated that in 1993, 50 detainees died while being detained in Tblisi interrogation cells.

${ }^{11}$ Prison officials could not provide prisoners with adequate food or medication. Infirmaries lacked medicines to counter outbreaks of diseases. Prisons were severely overcrowded, and interrogation cells are extremely cramped and unsanitary. Prisoners are not protected from violence and brutal treatment.

${ }^{12}$ Detainees are routinely beaten. Severe beatings take place. However it is not possible to discern exact numbers from the report. Human rights groups report significantly less abuses than in 1993. Most of the abuse takes place in pre-trial detention. Some abuse also takes place during trials.

${ }^{13}$ The 250,000 people that fled fighting in Abkhazia have not been allowed to return. Legislation to allow the Mshketians to return had not been passed yet.

${ }^{14}$ Forty people died in pre-trial detention, some because of poor conditions, but some also of physical abuse and torture. There was a series of assassinations (and attempts) against political figures. The Governments and the Ministry of Interior have accused the SGB (former KGB) of involvement.

${ }^{15}$ Conditions are inhumane. Cells, medicine and food are inadequate. In one pre-trial detention facility there is such severe overcrowding that prisoners must sleep in shifts as there are not enough beds. Lack of sanitation, medical care, and food poses a serious threat to life and health.

${ }^{16}$ Although torture is not systematic as such, lack of professionalism and lack of training often lead to abuse. There are a number of cases of torture in the report.
} 
${ }^{17}$ Education is officially free. However many parents can not afford the books and school supplies, effectively depriving their children of education.

${ }_{18}$ There is a dramatic rise in the number of homeless children. There are an estimated 1,000 street children in Tblisi.

${ }^{19}$ Non-Abkhazians still face many problems trying to return to Abkhazia. In South Ossetia there is also considerable reluctance for those who fled to return. The problem regarding the Meshkatian remains unresolved, although pilot programs for small groups to return have been continuing.

${ }^{20}$ There were 13 deaths in pre-trial detention and 74 died in prison. However the majority of these deaths were due to medical causes. In some deaths physical abuse and torture also played a role.

${ }^{21}$ Conditions are inhumane. Cells, medicine and food are inadequate. In one pre-trial detention facility there is such severe overcrowding that prisoners must sleep in shifts as there are not enough beds. Lack of sanitation, medical care, and food poses a serious threat to life and health. The spread of tuberculosis is a particular problem. Moreover the ICRC was allowed unlimited access to prisons, however visits with prisoners were sometimes supervised.

${ }_{22}$ There were instances of torture. The most serious instances of abuse take place in pre-trial detention. Most abuse is caused by improper and lack of training of guards and investigators.

${ }^{23}$ Education is officially free. However many parents can not afford the books and school supplies, effectively depriving their children of education.

${ }^{24}$ There is a dramatic rise in the number of homeless children. There are an estimated 1,000 street children in Tblisi.

${ }^{25}$ Though officially supporting the repatriation of Meshketian Muslims all pilot programs to resettle a number of families were never started and Meshketian still face a lot of opposition to their return. Abkhazian separatists prevented the nearly 270,000 displaced people from returning. In South Ossetia separatists also prevented displaced people from returning.

2692 people died while in prison or pre-trial detention. All of these deaths were attributed to medical causes. However torture and abuse also played in role in the mortality rate.

${ }^{27}$ Conditions are inhumane. Cells, medicine and food are inadequate. In one pre-trial detention facility there is such severe overcrowding that prisoners must sleep in shifts as there are not enough beds. Lack of sanitation, medical care, and food poses a serious threat to life and health. The spread of tuberculosis is a particular problem. Moreover the ICRC was allowed unlimited access to prisons and prisoners. The issuing of a decree by President Shevardnadze calling for the halt to torture and inhuman or degrading treatment was followed by greater cooperation between government officials and international human rights monitors.

${ }^{28}$ The report mentions beatings and abuse of detainees and prisoners is routine. These beatings when severe fall within the realm of the definition of torture. It is clear from the report a number of beatings and certain abuse is torture and practised by security forces. However it is not clear how many cases that fit the definition of torture have been reported.

${ }^{29}$ Education is officially free. However many parents can not afford the books and school supplies, effectively depriving their children of education.

${ }^{30}$ In order to survive children increasingly turn to (criminal activity, narcotics and) prostitution.

${ }^{31}$ There is a dramatic rise in the number of homeless children. There are an estimated 1,000 street children in Tblisi. In the winter street children die of exposure.

${ }^{32}$ Though officially supporting the repatriation of Meshketian Muslims Meshketians still face a lot of opposition to their return. Abkhazian separatists prevented the nearly 270,000 displaced people from returning. In South Ossetia separatists also prevented displaced people from returning.

${ }^{33} 88$ persons died in prison and in pre-trial detention. "These deaths were caused in part by physical abuse, torture, and inhuman prison or pre-trial detention conditions". Although this language is clearer than previous reports in which some of the deaths could in part be attributed to torture and abuse, it still is unclear how many were cases of torture there were. Georgian partisans in the Abkhazian conflict committed political killings, in previous years these partisans were supported by the government. The government claims that this is no longer the case.

${ }^{34}$ Conditions are inhumane. Cells, medicine and food are inadequate. In one pre-trial detention facility there is such severe overcrowding that prisoners must sleep in shifts as there are not enough beds. Lack of sanitation, medical care, and food poses a serious threat to life and health. The spread of tuberculosis is a particular problem. Moreover the ICRC was allowed unlimited access to prisons and prisoners. The issuing of a decree by President Shevardnadze calling for the halt to torture and inhuman or degrading treatment was followed by greater cooperation between government officials and international human rights monitors.

${ }^{35}$ As in previous reports it is unclear how many cases of torture there were. It is however more clear in this report that there was torture as this is explicitly mentioned. The report also mentions that there was a decline in the number of cases of torture and abuse, because Georgian society was opening up more, there was "increased intolerance of police misconduct, greater public awareness off civil rights, and pressure from the international community. Interestingly a report of Amnesty International is briefly mentioned. This report states that there were many cases of torture. However it is difficult to place within the report. It is impossible to discern from this passage whether State Department endorses this view.

${ }^{36}$ Education is officially free. However many parents can not afford the books and school supplies, effectively depriving their children of education. 
${ }^{37}$ In order to survive children increasingly turn to (criminal activity, narcotics and) prostitution.

${ }^{38}$ Due to economic hardship, families break up and children end up on the street. There are now more than 2,500 children on the streets of Tblisi.

${ }^{39}$ In Gali region in Abkhazia many houses were burnt.

${ }^{40}$ As violence erupted in the Gali region in Abkhazia many civilians $(40,000)$ were forced to flee as their houses were being looted and burned.

${ }^{41}$ Though officially supporting the repatriation of Meshketian Muslims Meshketians still face a lot of opposition to their return. Meshketians live as stateless persons. A new law to rehabilitate victims from the Soviet era (including the Meshketians) is probably going to be passed in 1999. Abkhazian separatists prevented the nearly 270,000 displaced people from returning. In South Ossetia separatists also prevented displaced people from returning.

${ }^{42} 57$ prisoners died and 9 prisoners died while in pre-trial detention. NGO's and the press allege physical abuse, torture and prison or pre-trial detention conditions contributed to the pre-trial deaths. Georgian partisans in the Abkhazian conflict committed political killings, in previous years these partisans were supported by the government. The government claims that this is no longer the case.

${ }_{43}$ Conditions are inhumane. Cells, medicine and food are inadequate. In one pre-trial detention facility there is such severe overcrowding that prisoners must sleep in shifts as there are not enough beds. Lack of sanitation, medical care, and food poses a serious threat to life and health. The spread of tuberculosis is a particular problem. A new law was passed in accordance with the requirements of the Council of Europe. The new law provides for transfer of responsibility for prisons from the Ministry of Interior to the Ministry of justice. this is seen as a move that will improve conditions.

${ }^{44}$ As in previous reports it is unclear how many cases of torture there were. It is however more clear in this report that there was torture as this is explicitly mentioned. The report also mentions that there was another decline in the number of cases of torture and abuse, because Georgian society was opening up more, there was "increased intolerance of police misconduct, greater public awareness off civil rights, and pressure from the international community. A HRW report is mentionned and seems to be endorsed, stating that mistreatment and abuse of detainees continued to be rampant.

${ }^{45}$ Education is officially free. However many parents can not afford the books and school supplies, effectively depriving their children of education. In orphanages, children received inadequate education.

${ }^{46}$ In order to survive children increasingly turn to (criminal activity, narcotics and) prostitution.

${ }^{47}$ Due to economic hardship, families break up and children end up on the street. There are now more than 2,500 children on the streets of Tblisi.

${ }^{48}$ The Meshketian still were unable to return as there was great societal opposition. Those who live in the area they want to return to are concerned the ethnic balance of the area will be upset. The law passed in 1997 on the rehabilitation of Soviet victims was not adopted. Instead, in compliance with Council Of Europe recommendations the Government undertook to begin the process of Meshketian repatriation within three years. Abkhazian separatists prevented the nearly 270,000 displaced people from returning. In South Ossetia separatists also prevented displaced people from returning.

${ }^{49} 61$ prisoners died in prison, and 5 died while in pre-trial detention. Some of the deaths are the result of security force abuses. Georgian partisans in the Abkhazian conflict committed political killings, in previous years these partisans were supported by the government. The government claims that this is no longer the case.

${ }_{50}$ Conditions are inhumane. Cells, medicine and food are inadequate. Lack of sanitation, medical care, and food poses a serious threat to life and health. The infrastructure is crumbling. The spread of tuberculosis is a particular problem. A new law was passed in 1999 in accordance with the requirements of the Council of Europe. The new law provides for transfer of responsibility for prisons from the Ministry of Interior to the Ministry of justice. The transfer did not go accompanied by fiscal changes. The consequent lack of resources resulted in a worsening of the situation.

${ }^{51}$ There was an increase in abuse following the April elections. Part of this abuse was torture. The report mentions the fact that domestic human rights advocates reported an increase in torture. The report also mentions the fact that police sometimes beat and rape prostitutes, beat members of religious minorities and harassed and abused street children.

${ }^{52}$ Education is officially free. However many parents can not afford the books and school supplies, effectively depriving their children of education. In orphanages, children received inadequate education. The Ministry of Education said it was beginning an overhaul of the educational system. However no action has as yet been taken.

${ }_{53}$ In order to survive children increasingly turn to (criminal activity, narcotics and) prostitution.

${ }^{54}$ The Isolator for street children (not a prison or detention centre as such) in Gldani is overcrowded and the children are frequently abused.

${ }^{55}$ Due to economic hardship, families break up and children end up on the street. There are now more than 2,500 children on the streets of Tblisi. Police frequently abused and harassed street children.

${ }^{56}$ The Meshketian still were unable to return as there was great societal opposition. Those who live in the area they want to return to are concerned the ethnic balance of the area will be upset. The law passed in 1997 on the rehabilitation of Soviet victims was not adopted. Instead, in compliance with Council Of Europe recommendations the Government undertook to begin the process of Meshketian repatriation within three years. Abkhazian separatists prevented the nearly 270,000 displaced people from returning. In South Ossetia separatists also prevented displaced people from returning. 
${ }^{57}$ In the first ten months of the year 27 prisoners died in prison, of which nine died of tuberculosis. Some of the deaths are the result of security force abuses.

${ }^{58}$ Prisons are overcrowded, unsanitary, understaffed, and are in desperate need of repair. There is lack of proper ventilation, plumbing, lighting, waste disposal, and/or sanitary medical facilities. The problem of lack of electricity and poor (or no) pay for guards were worsened by the transfer of responsibility for prisons to the Ministry of Justice. Some steps were taken to alleviate the problem of overcrowding, but the problem remained. Torture and abuse of prisoners was a problem and led to deaths in custody. The spread of disease (especially tuberculosis) was a great problem. Rape of inmates was common. Suicides and self mutilation increased as conditions declined.

${ }^{59}$ There was an increase in abuse following the April 2000 elections. Part of this abuse was torture. The report mentions a report by HRW which states that torture increased again during the year. The report also mentions the fact that police beat and rape prostitutes, beat members of religious minorities and harassed and abused street children. There are conflicting reports on whether the abuse is worse outside the great cities. The State Department believes it is. However the also quote from a report of a local NGO that states that at village level personal relationships work to prevent abuse.

${ }^{60}$ Education is officially free. However many parents can not afford the books and school supplies, effectively depriving their children of education. In orphanages, children received inadequate education. The Ministry of Education said it was beginning an overhaul of the educational system. However no action has as yet been taken.

${ }^{61}$ In order to survive children increasingly turn to (criminal activity, narcotics and) prostitution.

${ }^{62}$ The Isolator for street children (not a prison or detention centre as such) in Gldani is overcrowded and the children are frequently abused.

${ }^{63}$ Due to economic hardship, families break up and children end up on the street. There are now more than 2,500 children on the streets of Tblisi. Police frequently abused and harassed street children.

${ }^{64}$ The Meshketian still were unable to return as there was great societal opposition. Those that live in the area they want to return to are concerned the ethnic balance of the area will be upset. The law passed in 1997 on the rehabilitation of Soviet victims was not adopted. Instead, in compliance with Council Of Europe recommendations the Government undertook to begin the process of Meshketian repatriation within three years. Abkhazian separatists prevented the nearly 270,000 displaced people from returning. Although it seems IDP's from Gali region travel back and forth to tend to their property. The report states 40,000 now live in the Gali Region. In South Ossetia separatists also prevented displaced people from returning.

${ }^{65}$ There were 34 deaths in custody. 31 deaths were attributed to suicide disease or sickness. Some of the deaths are the result of security force abuses.

${ }^{66}$ According to the U.N. and many NGO's conditions in prisons remained life threatening and inhumane. Prisons are overcrowded, unsanitary, understaffed, and are in desperate need of repair. There is lack of proper ventilation, plumbing, lighting, waste disposal, and/or sanitary medical facilities. The problem of lack of electricity and poor (or no) pay for guards were worsened by the transfer of responsibility for prisons to the Ministry of Justice. Some steps were taken to alleviate the problem of overcrowding, but the problem remained. Typically though some prisons were at $50 \%$ capacity while in others there were 16 or more to cell designed for 10 to 12 prisoners. Torture and abuse of prisoners was widespread. The spread of disease (especially tuberculosis) was a great problem. Rape of inmates was common. Suicides and self mutilation increased as conditions declined. The Council of Europe expressed satisfaction with some of the progress achieved by the Ministry of Justice in its attempt to reform prison administration and conditions.

${ }^{67}$ The report states a report by the UNHCR which states torture continued. It also states reports by HRW that torture and abuse of detainees was a major problem. Increasingly confessions are made in police stations instead of pre-trial detention centres. To counter abuse and torture the Human Rights Ombudsman instituted a rapid reaction group in January with the support of the OSCE. "This pilot project had the mandate to provide immediate response to all claims of human rights violations during the most critical phase, the first 72 hours of a person's detention." There were no reports of police beating and raping prostitutes or beating members of religious minorities. There was an increase in the number of cases of abuse investigated by the Prosecutor General's office.

${ }^{68}$ Education is officially free. However many parents can not afford the books and school supplies. Moreover many parents were forced to pay some form of tuition fee or teacher's salary. Most children of school age attended school. However in some places schools did not function, because teachers were not paid and facilities were inadequate (especially in the winter as some schools could not afford to heat the buildings). There was a lack of libraries or even blackboards. In orphanages, children received inadequate education. The Ministry of Education said it was beginning an overhaul of the educational system. However no action has as yet been taken.

${ }^{69}$ In order to survive children increasingly turn to (criminal activity, narcotics and) prostitution.

${ }^{70}$ The Isolator for street children (not a prison or detention centre as such) in Gldani is overcrowded and the children are frequently abused.

${ }^{71}$ Due to economic hardship, families break up and children end up on the street. There are now more than 1,500 children on the streets in the country (1,200 of which in Tblisi). Police increasingly abused and harassed street children.

${ }^{72}$ The Meshketian still were unable to return as there was great societal opposition. Those who live in the area they want to return to are concerned the ethnic balance of the area will be upset. The law passed in 1997 on the rehabilitation of Soviet victims was not adopted. Instead, in compliance with Council Of Europe recommendations the Government undertook to begin the process of Meshketian repatriation within three years. However no 
legislation on this subject has been passed as of today. Abkhazian separatists prevented the nearly 270,000 displaced people from returning. Although it seems IDP's from Gali region travel back and forth to tend to their property. The report states 40,000 now live in the Gali Region. In South Ossetia separatists also prevented displaced people from returning. 


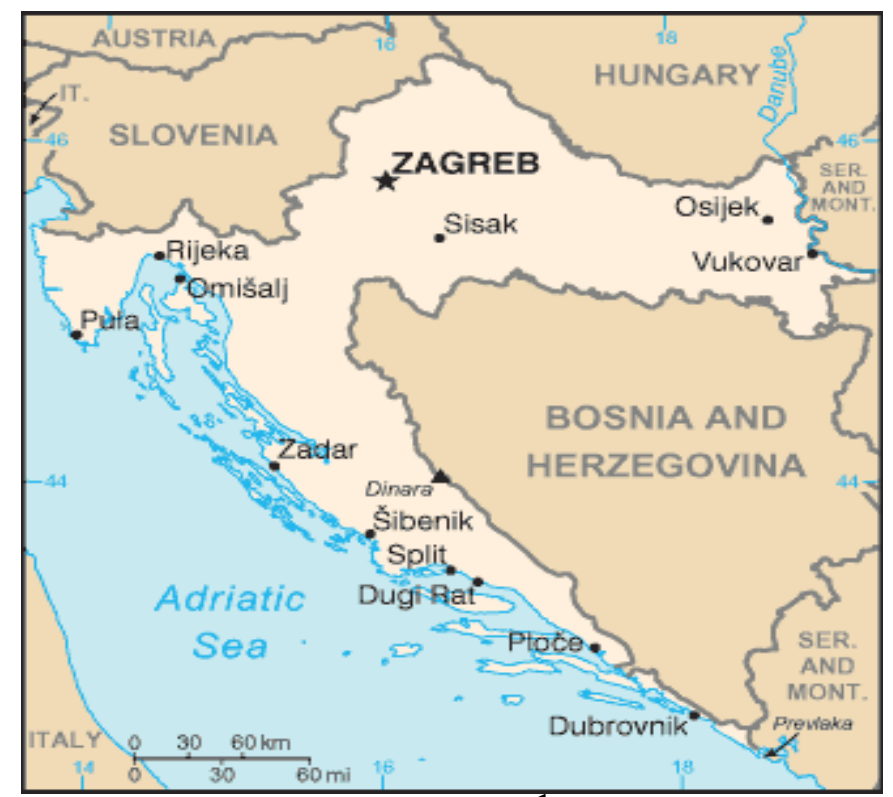

Croatia $^{1}$

(population: 4,422,248)

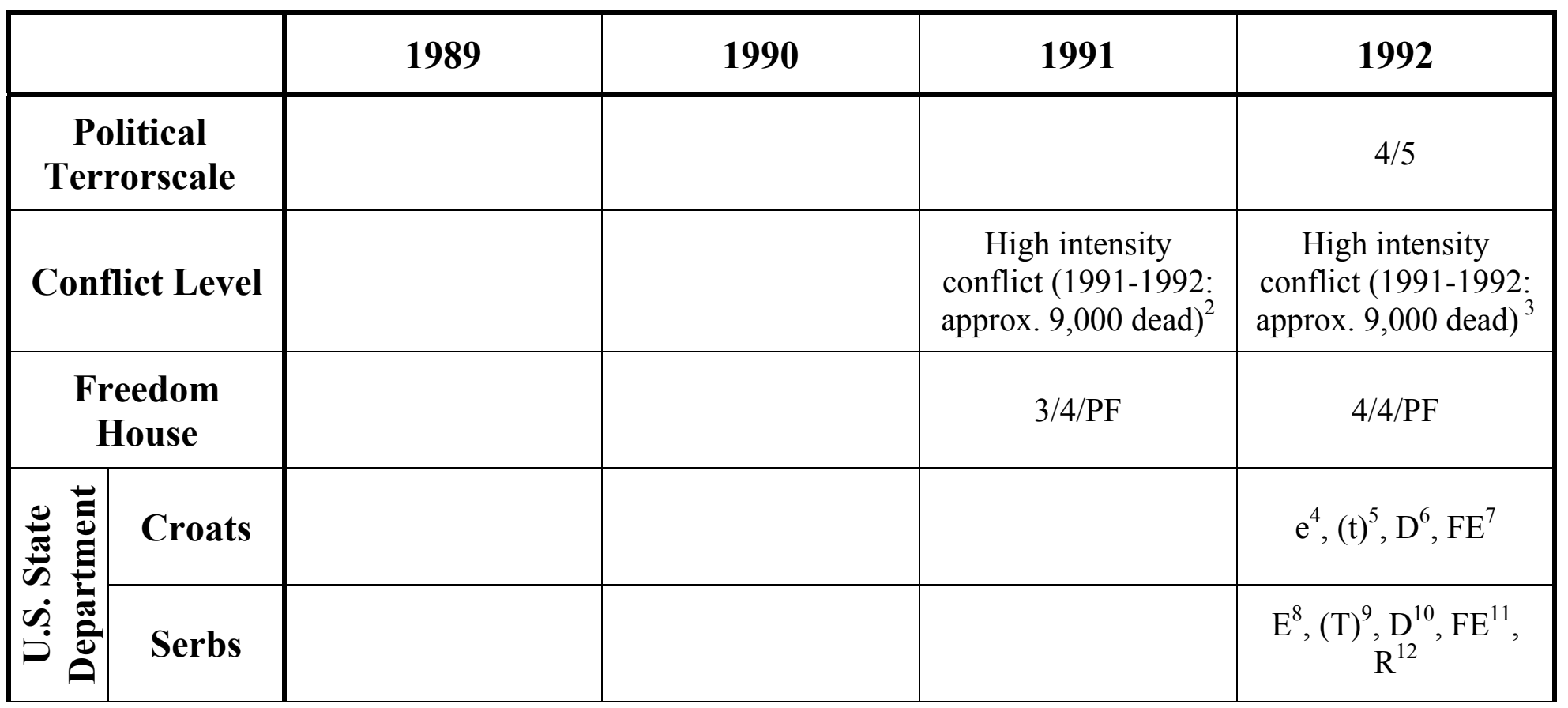

\begin{tabular}{|c|c|c|c|c|c|}
\hline & 1993 & 1994 & 1995 & 1996 \\
\hline \multicolumn{2}{|c|}{$\begin{array}{c}\text { Political } \\
\text { Terrorscale }\end{array}$} & $3 / 5^{13}$ & $2 / 5^{14}$ & $5 / 5$ & $3 / 3$ \\
\hline \multicolumn{2}{|c|}{ Conflict Level } & $\begin{array}{l}\text { Low intensity } \\
\text { conflict }\end{array}$ & $\begin{array}{c}\text { Violent political } \\
\text { conflict (state dept. } \\
\text { figures) }\end{array}$ & $\begin{array}{c}\text { High intensity } \\
\text { conflict (Krajina and } \\
\text { Slavonia) }\end{array}$ & \\
\hline \multicolumn{2}{|c|}{$\begin{array}{c}\text { Freedom } \\
\text { House }\end{array}$} & $4 / 4 / \mathrm{PF}$ & $4 / 4 / \mathrm{PF}$ & $4 / 4 / \mathrm{PF}$ & $4 / 4 / \mathrm{PF}$ \\
\hline \multirow{2}{*}{ 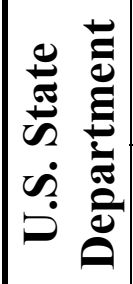 } & Croats & $\begin{array}{c}\mathrm{E}^{15}, \mathrm{CA}^{16}, \mathrm{D}^{17}, \mathrm{DH}^{18}, \\
\mathrm{FE}^{19},\end{array}$ & $\mathrm{t}^{20}, \mathrm{DH}^{21}, \mathrm{FE}^{22}$ & $\begin{array}{c}\mathrm{E}^{23}, \mathrm{p}^{24}, \mathrm{t}^{25}, \mathrm{AE}^{26} \\
\mathrm{D}^{27}, \mathrm{DH}^{28}, \mathrm{FE}^{29}, \mathrm{R}^{30}\end{array}$ & $\mathrm{DH}^{31}, \mathrm{FE}^{32}, \mathrm{R}^{33}$ \\
\hline & Serbs & $\mathrm{E}^{34}, \mathrm{P}^{35}, \mathrm{t}^{36}, \mathrm{D}^{37}, \mathrm{FE}^{38}$ & $\mathrm{E}^{39}, \mathrm{P}^{40}, \mathrm{t}^{41}, \mathrm{FE}^{42}$ & $\mathrm{E}^{43}, \mathrm{P}^{44}, \mathrm{t}^{45}, \mathrm{D}^{46}, \mathrm{FE}^{47}$ & \\
\hline
\end{tabular}




\begin{tabular}{|c|c|c|c|c|}
\hline $\begin{array}{c}\text { Political } \\
\text { Terrorscale }\end{array}$ & 1997 & $\mathbf{1 9 9 8}$ & $\mathbf{1 9 9 9}$ & $\mathbf{2 0 0 0}$ \\
\hline $\begin{array}{c}\text { Conflict Level } \\
\text { Freedom } \\
\text { House }\end{array}$ & 3 & 2 & & 2 \\
\hline $\begin{array}{c}\text { U.S. State } \\
\text { Department }\end{array}$ & $\begin{array}{c}(\mathrm{t})^{48},(\mathrm{AE})^{49}, \mathrm{D}^{50}, \\
\mathrm{DH}\end{array}$ & $\begin{array}{c}\mathrm{e}^{54},(\mathrm{t})^{55}, \mathrm{AE}^{52}, \mathrm{R}^{53}, \mathrm{DH}^{57}, \\
\mathrm{FE}^{58}, \mathrm{R}^{59}\end{array}$ & $(\mathrm{t})^{60}, \mathrm{AE}^{61}, \mathrm{DH}^{62}$, & $2 / 3 / \mathrm{F}$ \\
\hline
\end{tabular}

\begin{tabular}{|c|c|c|}
\hline & $\mathbf{2 0 0 1}$ & $\mathbf{2 0 0 2}$ \\
\hline $\begin{array}{c}\text { Political } \\
\text { Terrorscale }\end{array}$ & & \\
\hline Conflict Level & & \\
\hline $\begin{array}{c}\text { Freedom } \\
\text { House }\end{array}$ & $3 / 2 / \mathrm{F}$ & \\
\hline $\begin{array}{c}\text { U.S. State } \\
\text { Department }\end{array}$ & $\mathrm{AE}^{68},(\mathrm{CA})^{69}, \mathrm{DH}^{70}$, & $\mathrm{AE}^{72},(\mathrm{CA})^{73}, \mathrm{DH}^{74}$, \\
\end{tabular}

\section{Working conditions:}

1994: Government does not effectively enforce health and safety regulations.

1997: Health and safety standards are not effectively enforced.

1998: Health and safety standards are not effectively enforced.

1999: Health and safety standards are not effectively enforced.

2000: Health and safety standards are not effectively enforced.

2001: Health and safety standards are not effectively enforced.

2002: Health and safety standards are not effectively enforced.

\section{$\underline{\text { Brief historical/political overview }}$}

1992: The Republic of Croatia declared its independence on June 25 1991, and sought international recognition. This move precipitated a war with the federal (Yugoslav) authorities in which they sent the Yugoslav National Army (JNA) led predominantly by Serbian and Montenegrin officers against Croatian towns and cities. The JNA established control over a number of areas where Croatian residents of Serbian nationality were predominant, as well as over areas where Serbs had been the minority. The JNA was assisted by paramilitary forces and Serb irregulars. These elements were often led by JNA officers or their surrogates and all were directly supplied weapons and ammunition by the JNA. On January 3 a cease fire agreement, known as the Vance Plan, was agreed upon. The agreement provided for demilitarisation, 
return of displaced persons and the establishment of a Croatian government authority. Part of the agreement provided for a UN protection force (UNPROFOR) to be deployed to areas of Croatia occupied by the Serbs. The Serbs would have to leave and the UN force would have taken their positions in the spring or summer. However many Serb troops stayed on in the occupied areas and converted themselves into special police forces. The JNA finally only left in the first week of November. Croatia was recognised by the EU on January 15 and by the US on April 8. On July 18 Serbian 'authorities' declared the 'Serbian Autonomous Region of Krajina" and set up "governmental institutions". In presidential and parliamentary election Franjo Tudjman was re-elected for a five year term. Ethnic cleansing continued. Both sides were guilty of this practice. However the Serbs used ethnic cleansing massively. There is serious discrimination against Serbs.

1993: Little progress was made implementing the Vance plan. The UNPROFOR was not able to prevent outbreaks of fighting between Croats and Serbs as well as the daily shelling of Zadar and other areas along the Dalmatian coast from the Serb-controlled areas of the UN Protected Areas. In February the UN Security Council passed a resolution to create a war crimes tribunal. The "ethnic cleansing of non-Serbs in the Republic of Serbian Krajina is largely a fait accompli. In March the International Federation of Journalists suggested that Croatia's admission to the Council of Europe should be delayed, because it was "very concerned" about the freedom of the press in Croatia.

1994: One-quarter of Croat land continued to be occupied by rebel Serbs. No progress was made in implementing the Vance Peace Plan. A March ceasefire created a 2-kilometer-wide zone of separation and led to a dramatic decrease in violence. In December the Government and the rebel Serbs agreed upon a package of economic and confidence-building measures, the implementation of which began with the opening of the Zagreb-Belgrade highway to civilian traffic on December 21. Government influence weakens the nominally independent judiciary. The use of violence by security forces against Serbs in government-controlled areas declined, cases of disappearances and harassment continued near the frontline areas. There were few new cases of disappearances reported. Many attacks in Bosnia Herzegovina were initiated from Croat and Serb-controlled territory (such as attacks launched on the Bihac pocket from RSK, and the forcible recruiting of Croatian citizens originally from Bosnia into Bosnian Croat paramilitary forces).

1995: Government influence weakens the nominally independent judiciary. The overwhelming dominance of one political party tend to stifle the expression of diverse views. The Government launched two major offensives in May and August against three rebel Serb-held zones and recovered the territory after 4 years of breakaway Serb occupation. Only the Eastern area of Croatia remains outside effective government control, although both the Government and local Serb leaders signed an agreement in mid-November to bring this area under complete government control after a transitional period of 1 to 2 years. A report of the Croatian Helsinki Committee for Human Rights. stated that in the 1995 offensive by Croatian troops (operation "Storm") some 600 Serbs were killed (report published in 1999). Government's human rights record worsened with respect to minority groups, especially ethnic Serbs. The bulk of violent abuses were committed in recaptured territory. Prior to the offensive in May there had been building tensions. However the direct pretext for the attack was the murder of three Croats, who were shot on the highway from behind Serb lines. In October elections for the House of Representatives were won by the ruling HDZ. The elections were considered flawed on certain points. All minorities in Croat and Serb controlled areas were discriminated against.

1996: Government influence weakens the nominally independent judiciary. The overwhelming dominance of one political party tend to stifle the expression of diverse views. Croatia normalized relations with neighbouring Serbia-Montenegro on August 23. In Eastern Slavonia the U.N. established a Transitional Administration for Eastern Slavonia. Cooperation with the International Criminal Tribunal for the Former Yugoslavia was uneven. There were several reports of ethnically motivated killings by unknown persons. The vast majority of victims were Serbs. The murders were fewer than last year, but continued a pattern begun in 1995 of murders intended to intimidate Serbs who stayed behind after Croatia reclaimed areas and discourage those Serbs who fled from returning. Serbs suffered particular and increasingly open discrimination. Other minorities were less discriminated against than Serbs. 
1997: Franjo Tudjman is re-elected in June for a second five-year term, in elections international observers called fundamentally flawed. The ruling HDZ uses its entrenched majority position to deny opposition parties the ability to compete on fair and equal terms in elections. Government influence circumscribes and weakens the judiciary. This and other elements make Croatia's nominally democratic system in reality authoritarian. The United Nations Transitional Administration for Eastern Slavonia mandate was ended on January 1998. In September the European Convention on Human Rights is ratified. Cooperation with ICTY remained uneven. There still were a number (though lower than previous years) of ethnically motivated murders which affect in great majority ethnic Serbs. There was an increase in Western Slavonia and Krajina of attacks on Serb homes. Discrimination of Serbs is ever present and often open. There is also discrimination, though not to the same extent, of other minorities, Muslims, Slovaks, Czechs, Italians, Hungarians and Roma.

1998: Though the country is nominally democratic its system is in reality authoritarian. The judicial system is subject to executive and political influence. Cooperation with the ICTY was mixed. There were a small number of ethnically motivated murders. Violent incidents, particularly in the Danubian region and in the former Sector South, rose in the summer months. Since 1996 47,000 ethnic Serbs left Croatia, with 20,000 leaving in 1997 alone. Destruction of Serb homes continued (without involvement of the authorities, but destruction also went unpunished). Early in the year the Parliament decided to omit Albanians, Muslims, and Slovenes from those minorities listed in the Constitution on the grounds that they are not considered indigenous groups. This elimination effectively denies them rights in the (albeit partially suspended) Constitutional Law on the Rights of Ethnic and National Communities or Minorities.

1999: In December President Tudjman dies. New parliamentary elections were held in January 2000, new Presidential elections are to be held in February 2000. Parliament Speaker Vlatko Pavletic was named acting President. The country is nominally democratic, but in reality authoritarian. However on January 3 the ruling HDZ lost generally well-conducted parliamentary elections to an opposition coalition. Cooperation with the ICTY was mixed. Ethnic Serbs and Roma were particularly discriminated against. Three ethnically motivated killings of ethnic Serbs. Incidents of grenade attacks against property and arson related to housing disputes were reported during the year. There was a decrease of ethnically motivated violence. Discrimination of other minorities Muslims, Slovaks, Czechs, Italians, Hungarians, did not reflect discrimination to the same extent as the Serb community.

2000: President Stjepan Mesic of the HNS was elected for a 5 year term in February. Ivica Racan is the Prime Minister. The elections were "calm and orderly", the elections were generally free, however some problems remain. The combination of a new President and a new Parliament (elected I January, see 1999) gave the role of the President more transparency and put an end to the blurring of the role of the President, the Government and the ruling party. The judiciary gained more independence. However problems of dependence remained. Reports of harassment of journalists and censorship virtually ceased. There remained significant discrimination of Serbs and Roma, in particular. Though new laws on minorities were passed. During the year there were 2 ethnically motivated murders of ethnic Serbs.

2001: The judiciary began reform and modernization efforts during the year. Cooperation with ICTY continued to improve. There remained significant discrimination of Serbs and Roma, in particular.

2002: There remained significant discrimination of Serbs and Roma, in particular.

\footnotetext{
${ }^{1}$ Croatian forces committed major human rights abuses in Bosnia. These will not be mentioned in this table.

${ }^{2}$ CAT/C/16/Add.6 (1996)

${ }^{3}$ CAT/C/16/Add.6 (1996)

${ }^{4}$ There were credible reports of killings of Serbs.

${ }^{5}$ POW's are generally treated harshly. Beatings were sometimes used. However it is not clear whether the severity of the beatings would make it torture.

${ }^{6}$ Bombing of houses and setting fire to houses in an effort to drive people out.

${ }^{7}$ In revenge attacks Croat extremists sometimes drove Serbs out of their homes.

${ }^{8}$ There were numerous killings often with the complicity of local Serb "authorities". Many disappeared in Serb controlled areas of Croatia.

${ }^{9}$ In Serbian controlled areas harsh treatment in places of detention is common. It is not known whether torture would fall under this harsh treatment.
} 
${ }^{10}$ Bombing of houses and setting fire to houses in an effort to drive people out. The Serbs were especially aggressive in ethnic cleansing harassing non-Serbs until they fled and "voluntarily" signed over their property to Serbs.

${ }^{11}$ It is the practice of Serb "authorities" to drive non-Serbs out of their homes. These expulsions numbered in the thousands in Sectors East and South. The Serbs were especially aggressive in ethnic cleansing harassing non-Serbs until they fled and "voluntarily" signed over their property to Serbs.

${ }^{12}$ Displaced Croats were not able to return in Serb controlled areas.

${ }^{13}$ In our view both marks are right. The difference may be explained that in the State Department assesments the Serrbian Human Rights violations are taken into account.

${ }^{14}$ The difference may be explained that in the State Department assessment the Serbian Human Rights violations are taken into account. Moreover, the State Department mark is in our view not in accordance with the really mentioned violations and should be changed in our view to 3 or 4 which was not made by Purdue.

${ }^{15}$ However in two major offensives many civilians were killed. A number of those civilians appear to have been executed. Although there were fewer politically motivated or other extrajudicial killings than in 1992.

${ }^{16}$ Children (and women) were especially subjected to violence at the hands of men, including demobilised soldiers, acting out their frustrations and stresses. The violence is increasing.

${ }^{17}$ In one major attack Croatian armed forces systematically destroyed a number of villages.

${ }^{18}$ Serbs suffer from discrimination in housing.

${ }^{19}$ Throughout the year military police carried out illegal evictions from state-owned apartments.

${ }^{20}$ Security forces frequently beat and mistreated prisoners during detention and interrogation, particularly early in the year. Victims were Serbs and Muslims. Authorities had engaged in torture and beating of prisoners in Lora prison in Split. Victims were JNA reservists.

${ }^{21}$ Serbs suffer from discrimination in housing.

${ }^{22}$ Military or civil police carried out evictions by force, involving several hundred families, ethnic Serbs and Croats as well as Muslims.

${ }^{23}$ Between 300 and 500 killings in reclaimed parts of Croatia. Most killings were ethnically motivated and occurred long after the military offensives were over. Among those implicated in the killings were civilians, civil police, and active duty military personnel, especially members of the non-professional "home guard". Government forces were responsible for the indiscriminate deaths of many civilians and UN personnel.

${ }^{24}$ Conditions in short-term detention facilities used to house civilians rounded after military action did not meet international minimum standards.

${ }^{25}$ Some instances of torture. However there was no evidence of systematic torture in Croatian jails.

${ }^{26}$ Hungarians complained that only those children whose parents were both registered to be of Hungarian ethnicity could register in Hungarian schools, preventing many children of mixed background from attending.

${ }^{27}$ One-third of houses in recaptured areas were burned. Another one-third was heavily damaged and inhabitable.

${ }^{28}$ Serbs suffer from discrimination in housing.

${ }^{29}$ Forced eviction of Muslims from camps. They were then forcibly repatriated to Bosnia. Military police continued to carry out forced evictions, involving hundreds of families of all nationalities. Croatian civilians entered the homes of ethnic Serbs and other minorities who had lived for years in family apartments.

${ }^{30}$ It looks like new legislation makes it difficult for Serbs to return to their homes to reclaim them. The Government refused to allow the almost 200,000 refugees who fled the fighting to return to their homes in the former sectors north, south, and west.

${ }^{31}$ Serbs suffer from discrimination in housing.

${ }^{32}$ Forced eviction of Muslims from camps. They were then forcibly repatriated to Bosnia. Military police continued to carry out forced evictions, involving hundreds of families of all nationalities. Croatian civilians entered the homes of ethnic Serbs and other minorities who had lived for years in family apartments.

${ }^{33}$ Many non-Croats have found themselves effectively exiled from Croatia as they are not able to get the required papers in order to return to their homes.

${ }^{34}$ Killings continued to occur in the UNPA's as part of the Belgrade-backed Serbs' program of "ethnic cleansing". Serbs killed numerous civilians in a deliberate and indiscriminate campaign of artillery attacks on major Croatian cities and economic targets.

${ }^{35}$ Conditions in prisons within the Serb-controlled UNPA's are reliably reported to be abysmal. Harsh treatment is commonplace. Some were forced to sleep on concrete floor. Prisoners at one compound are always kept inside and fed only twice daily.

${ }^{36}$ In one detention centre there were reports of torture. Harsh treatment also continued.

${ }^{37}$ Since 1991 as many as 10,000 houses many owned by Croatian Serbs, have been blown up or razed. Many houses were destroyed in shelling.

${ }^{38}$ Ethnic cleansing resulted in many non-Serbs to be expelled from their homes and the areas they lived in.

${ }^{39}$ There were less killings. However a disproportionate number of homicide victims in the RSK were non-Serbs. It is alleged Serbian forces committed several murders along the confrontation line. In retaliation shelling of civilian areas of Zagreb six people were killed.

${ }^{40}$ Conditions in prisons within the Serb-controlled UNPA's are reliably reported to be abysmal. Harsh treatment is commonplace.

${ }^{41}$ There were at least two cases of psychological torture. It is not known whether harsh treatment also entails torture.

${ }^{42}$ The practice of forcibly moving Serbian refugees or soldiers into the homes of non-Serb residents continued.

${ }^{43} \mathrm{~A}$ disproportionate number of victims were non-Serbs. $6 \mathrm{UN}$ soldiers were killed. 
${ }^{44}$ Conditions in prisons within the Serb-controlled UNPA's are reliably reported to be abysmal. Harsh treatment is commonplace.

${ }^{45}$ There were credible reports of torture and other abuse. Harsh treatment of non-Serbs was commonplace. It is not known whether this harsh treatment amounts to torture.

${ }^{46}$ Shelling caused substantial damage to property.

${ }^{47}$ The practice of forcibly moving Serbian refugees or soldiers into the homes of non-Serb residents continued.

${ }^{48}$ There are occasional beatings of ethnic Serbs and mixed-marriage returnees. It is not known whether these beating amount to torture.

${ }^{49}$ Legislation regulating minority language education was deemed unduly restrictive by opponents.

${ }^{50}$ Police was involved in a two-day rampage with Bosnian Croats burning and vandalizing Serb homes.

${ }^{51}$ Ethnic Serbs and at times other minorities suffered from a pattern of ever present and often open discrimination in such area as housing.

${ }^{52}$ Forced evictions of ethnic Serbs, Croats and others from former JNA apartments continued in major cities throughout the year. Houses are confiscated when the tenants in a six-month absence have acted against the interests of Croatia. Membership of the JNA was enough to brand the tenants enemy of the State. Croats also were the victims f evictions. Many cases were reported in which desirable apartments were simply confiscated by individuals connected with either police or military.

${ }^{53}$ Although the Government reversed its stated opposition to the return of Serbs in July, the barriers erected for Serbs to return effectively exiled them from Croatia. Many Serbs were not allowed to return to their homes, even when these homes were empty.

${ }^{54}$ One Italian tourist was beaten to death by police.

${ }^{55}$ There are occasional beatings of ethnic Serbs and mixed-marriage returnees. It is not known whether these beating amount to torture.

${ }^{56}$ The majority of students continue their education to the age of 18 , with Roma being the only group reporting any notable exclusion. The Government blamed problems of Roma largely on linguistic and cultural differences that make their integration in schools difficult. Romani children face some discrimination and problems, due largely to these cultural and linguistic barriers at school. Ethnic Serb children are forced to follow the Croat curriculum. The following of a Serb curriculum remained problematical.

${ }^{57}$ Ethnic Serbs and at times other minorities suffered from a pattern of ever present and often open discrimination in such area as housing.

${ }^{58}$ In the Danubian region there were forcible evictions of Serbs on a weekly basis.

${ }^{59}$ Despite positive steps in legislation enabling Serbs to return, implementation was slow and many Serbs were unable to return to their homes. Croats often occupy these homes.

${ }^{60}$ There are occasional beatings (the report emphasises that Roma are often victim). It is not known whether these beating amount to torture.

${ }^{61}$ The majority of students continue their education to the age of 18 , with Roma being the only group reporting any notable exception. The Government blamed the problems of Roma largely on linguistic and cultural differences that make their integration in schools difficult. Romani children face some discrimination and problems, due largely to these cultural and linguistic barriers at school. The well-documented pattern of discriminatory application of laws and administrative regulations was also evident in education. There are still very few classes for Serb pupils who follow the approved Serbian school program.

${ }^{62}$ Ethnic Serbs and at times other minorities suffered from a pattern of open and severe discrimination in such area as housing.

${ }^{63}$ The OSCE and local human rights organizations reported forced evictions of ethnic Serbs from Croat-owned homes without receiving alternative accommodation on a weekly basis.

${ }^{64}$ The return of Serbs moved slowly, especially due to persistent difficulties, and delays, and contradictory requirements by local officials. It still was not possible for Serbs to return to their homes, because they were often occupied by ethnic Croats. The problem of houses being occupied when the original occupants had not occupied the house for a period of six months still went unresolved. The "six-months rule" affected ethnic Serbs disproportionally.

${ }^{65}$ The majority of students continue their education to the age of 18 , with Roma being the only group reporting any notable exception. Romani children face serious discrimination in schools, and nearly all drop out by grade 8.The well-documented pattern of discriminatory application of laws and administrative regulations was also evident in education. There are still very few classes for Serb pupils who follow the approved Serbian school program.

${ }^{66}$ Ethnic Serbs and other minorities suffered from a pattern of open and severe discrimination in such area as housing.

${ }^{67}$ The return of Serbs moved slowly, especially due to persistent difficulties, and delays, and contradictory requirements by local officials. The restitution of occupied private property to, mostly ethnic Serbs, returning to the country remained a problem. It still was not possible for Serbs to return to their homes, because they were often occupied by ethnic Croats. The problem of houses being occupied when the original occupants had not occupied the house for a period of six months still went unresolved. The "six-months rule" affected ethnic Serbs disproportionally. The return of Serbs to Croatia did increase by $50 \%$.

${ }^{68}$ The majority of students continue their education to the age of 18 , with Roma being the only group reporting any notable exception. Romani children face serious discrimination in schools, and nearly all drop out by grade 8.The well-documented pattern of discriminatory application of laws and administrative regulations was also evident in education. There are still very few classes for Serb pupils who follow the approved Serbian school program. 
${ }^{69}$ While there is no pattern of abuse against children, NGO hotlines report numerous cases of abuse.

${ }^{70}$ Ethnic Serbs suffered from a pattern of open and sometimes severe discrimination in such area as housing.

${ }^{71}$ The restitution of occupied private property to, mostly ethnic Serbs, returning to the country remained a problem. It still was not possible for Serbs to return to their homes, because they were often occupied by ethnic Croats. The problem of houses being occupied when the original occupants had not occupied the house for a period of six months still went unresolved. The "six-months rule" affected ethnic Serbs disproportionally. The return of Serbs to Croatia did increase by $50 \%$.

${ }^{72}$ The majority of students continue their education to the age of 18 , with Roma being the only group reporting any notable exception. Romani children face serious discrimination in schools, and nearly all drop out by grade 8 .

${ }^{73}$ While there is no pattern of abuse against children, NGO hotlines report numerous cases of abuse.

${ }^{74}$ Ethnic Serbs suffered from a pattern of open and sometimes severe discrimination in such area as housing.

${ }^{75}$ The restitution of occupied private property to, mostly ethnic Serbs, returning to the country remained a problem. The problem of houses being occupied when the original occupants had not occupied the house for a period of six months still went unresolved. The "six-months rule" affected ethnic Serbs disproportionally. 


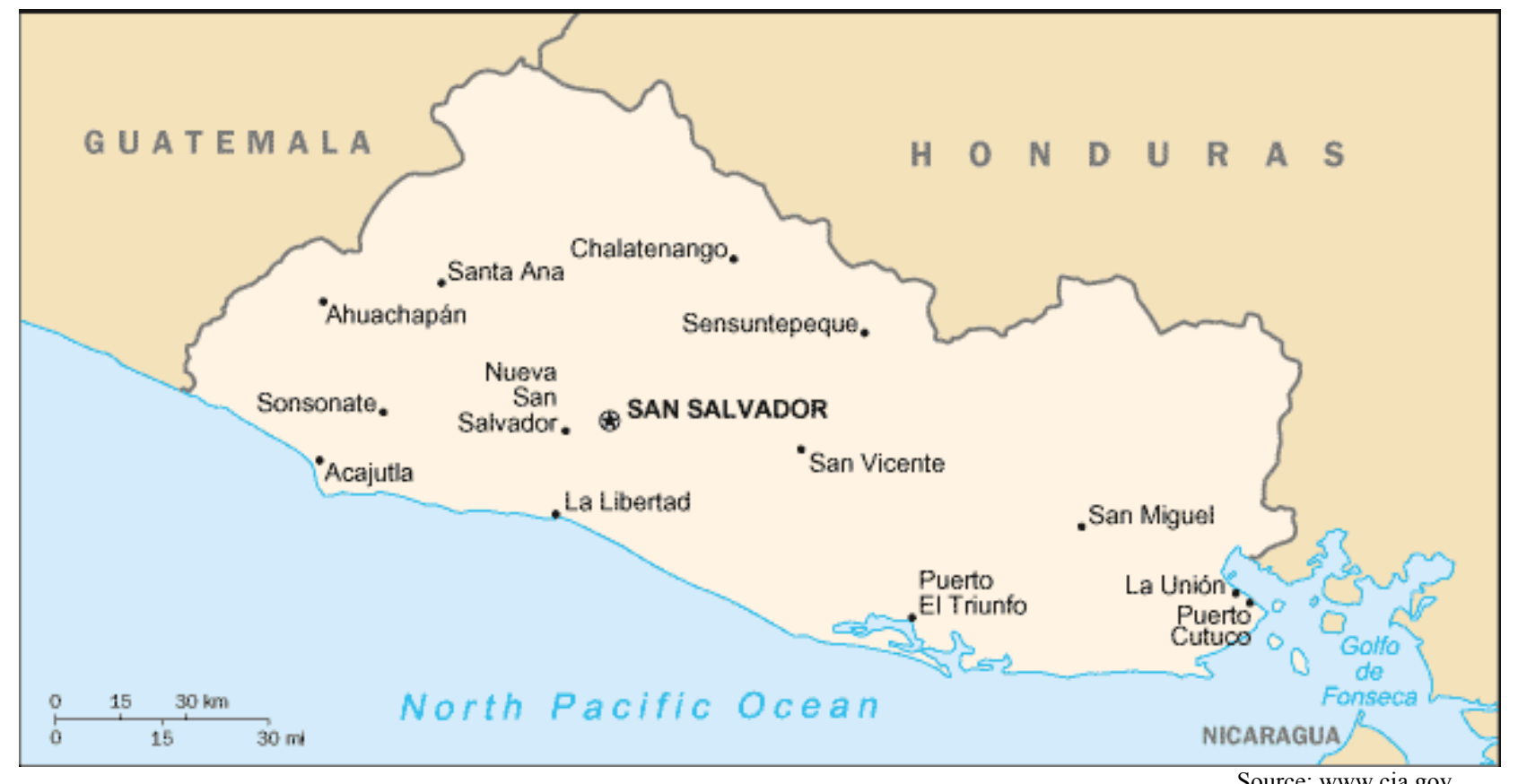

El Salvador ${ }^{1}$

(population: 6,470,379)

\begin{tabular}{|c|c|c|c|c|}
\hline & 1989 & 1990 & 1991 & 1992 \\
\hline $\begin{array}{c}\text { Political } \\
\text { Terrorscale }\end{array}$ & $4 / 4$ & $4 / 4$ & $4 / 4$ & $4 / 4$ \\
\hline Conflict Level & $\begin{array}{l}\text { High intensity armed } \\
\text { conflict (FMLN vs. } \\
\text { Government: Over } \\
\text { 3,000 deaths) }\end{array}$ & & $\begin{array}{c}\text { (peace accord on } 31 \\
\text { December) }\end{array}$ & \\
\hline $\begin{array}{c}\text { Freedom } \\
\text { House }\end{array}$ & $3 / 4 / \mathrm{PF}$ & $3 / 4 / \mathrm{PF}$ & $3 / 4 / \mathrm{PF}$ & $3 / 3 / \mathrm{PF}$ \\
\hline $\begin{array}{c}\text { U.S. State } \\
\text { Department }^{2}\end{array}$ & $E^{3}, T^{4}, C L^{5}$ & $E^{6}, t^{7}, C L^{8}$ & $\mathrm{e}^{9}, \mathrm{t}^{10}, \mathrm{CA}^{11}, \mathrm{CL}^{12}$ & $\mathrm{e}^{13}, \mathrm{t}^{14}, \mathrm{CL}^{15}$ \\
\hline $\begin{array}{c}\text { Amnesty } \\
\text { International }\end{array}$ & $E^{16}, T^{17}$ & ${ }^{18} \mathrm{E}^{19}, \mathrm{~T}^{20}$ & $E^{21}, T^{22}$ & $\mathrm{E}^{23}, \mathrm{t}^{24}, \mathrm{CL}^{25}$ \\
\hline
\end{tabular}

\begin{tabular}{|c|c|c|c|c|}
\hline & 1993 & 1994 & 1995 & 1996 \\
\hline $\begin{array}{c}\text { Political } \\
\text { Terrorscale }\end{array}$ & $4 / 3$ & $3 / 3$ & $2 / 3$ & $2 / 2$ \\
\hline
\end{tabular}




\begin{tabular}{|c|c|c|c|c|}
\hline Conflict Level & & & $\begin{array}{c}\text { Violent political } \\
\text { conflict }\end{array}$ \\
\hline $\begin{array}{c}\text { Freedom } \\
\text { House }\end{array}$ & $3 / 3 / \mathrm{PF}$ & $3 / 3 / \mathrm{PF}$ & $3 / 3 / \mathrm{PF}$ & $3 / 3 / \mathrm{PF}$ \\
\hline $\begin{array}{c}\text { U.S. State } \\
\text { Department }\end{array}$ & $\begin{array}{c}\mathrm{e}^{26}, \mathrm{t}^{27}, \mathrm{p}^{28}, \mathrm{CA}^{29}, \\
\mathrm{CL}^{30}, \mathrm{IF}^{31}\end{array}$ & $\begin{array}{c}\mathrm{e}^{32}, \mathrm{t}^{33}, \mathrm{p}^{34}, \mathrm{CA}^{35}, \\
\mathrm{CL} / \mathrm{FL}^{36}, \mathrm{IF}^{37}\end{array}$ & $\begin{array}{c}\mathrm{p}^{38}, \mathrm{CA}^{39}, \mathrm{CL}^{4} / \mathrm{FL}^{40}, \\
\mathrm{~S}^{41}, \mathrm{IF}^{42}\end{array}$ & $\begin{array}{c}(\mathrm{e})^{43}, \mathrm{p}^{44}, \mathrm{CA}^{45} \\
\mathrm{CL} / \mathrm{CP}^{46}, \mathrm{~S}^{47}, \mathrm{IF}^{48}\end{array}$ \\
\hline
\end{tabular}

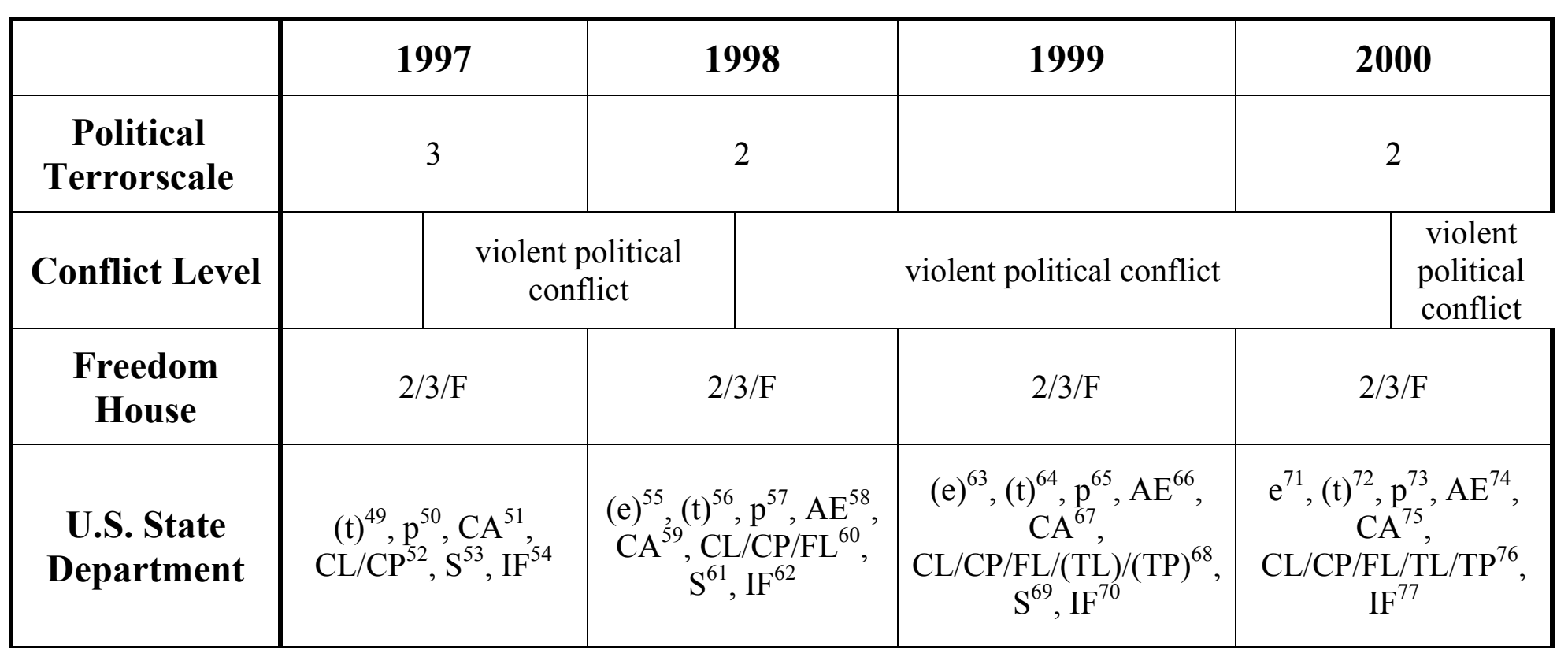

\begin{tabular}{|c|c|c|}
\hline & 2001 & 2002 \\
\hline \multicolumn{3}{|l|}{$\begin{array}{c}\text { Political } \\
\text { Terrorscale }\end{array}$} \\
\hline Conflict Level & $\begin{array}{c}\text { violent } \\
\text { political } \\
\text { conflict }^{78} \\
\end{array}$ & \\
\hline $\begin{array}{c}\text { Freedom } \\
\text { House }\end{array}$ & $2 / 3 / F$ & $2 / 3 / F$ \\
\hline $\begin{array}{c}\text { U.S. State } \\
\text { Department }\end{array}$ & $\begin{array}{c}\mathrm{e}^{79}, \mathrm{p}^{80}, \mathrm{AE}^{81}, \mathrm{CA}^{82}, \\
\mathrm{CL} / \mathrm{CP} / \mathrm{FL} / \mathrm{TL} / \mathrm{TP}^{83} \\
\mathrm{IF}^{84}\end{array}$ & $\begin{array}{c}\mathrm{e}^{85}, \mathrm{p}^{86}, \mathrm{t}^{87}, \mathrm{AE}^{88}, \\
\mathrm{CA}^{89}, \\
\mathrm{CL} / \mathrm{CP} / \mathrm{FL} / \mathrm{TL} / \mathrm{TP}^{90} \\
\mathrm{PC}^{91}, \mathrm{IF}^{92}\end{array}$ \\
\hline
\end{tabular}

\section{Working conditions:}

1990: The labour code and the constitution require employers to take steps ensuring that employees are not subject to risk at the workplace. There were numerous inspections, in which many infractions were found.

1991: The labour code and the constitution require employers to take steps ensuring that employees are not subject to risk at the workplace. There were numerous inspections, in which many infractions were found. Health and safety regulations are outdated and inadequate enforcement remains a problem. 
1992: Health and safety regulations are outdated and inadequate enforcement remains a problem. The Ministry of Labour attempts to seek compliance with the laws, but is seriously hampered through a lack of power. The Ministry is designing a new labour code.

1993: Health and safety regulations are outdated and inadequate enforcement remains a problem. Women and persons under 18 are forbidden to work in occupations considered hazardous.

1994: Health and safety regulations are outdated and inadequate enforcement remains a problem. Women and persons under 18 are forbidden to work in occupations considered hazardous. Workers can remove themselves from dangerous working conditions without jeopardizing their employment if they present a medical certificate indicating that their health is at risk while using certain equipment or substances.

1995: : Health and safety regulations are outdated and inadequate enforcement remains a problem. Women and persons under 18 are forbidden to work in occupations considered hazardous. Workers can remove themselves from dangerous working conditions without jeopardizing their employment if they present a medical certificate indicating that their health is at risk while using certain equipment or substances.

1996: Health and safety regulations are outdated and inadequate enforcement remains a problem. Women and persons under 18 are forbidden to work in occupations considered hazardous. Workers can remove themselves from dangerous working conditions without jeopardizing their employment if they present a medical certificate indicating that their health is at risk while using certain equipment or substances.

1997: Health and safety regulations are outdated and inadequate enforcement remains a problem. Women and persons under 18 are forbidden to work in occupations considered hazardous. Workers can remove themselves from dangerous working conditions without jeopardizing their employment if they present a medical certificate indicating that their health is at risk while using certain equipment or substances. The Government has directed more funds to the enforcement of existing laws.

1998: Health and safety regulations are outdated and inadequate enforcement remains a problem. Women and persons under 18 are forbidden to work in occupations considered hazardous. Workers can remove themselves from dangerous working conditions without jeopardizing their employment if they present a medical certificate indicating that their health is at risk while using certain equipment or substances. Increasingly the Ministry of Labour imposes fines or other punishment in favour of the workers. There are suspected "sweat shop" conditions in the maquila sector. Especially lack of ventilation (problem relating to dust and heat), and to a lesser extend the lack of bathrooms, drinking water, and eating facilities, were a problem in this sector.

1999: Health and safety regulations are outdated and inadequate enforcement remains a problem. Women and persons under 18 are forbidden to work in occupations considered hazardous. Workers can remove themselves from dangerous working conditions without jeopardizing their employment if they present a medical certificate indicating that their health is at risk while using certain equipment or substances. Increasingly the Ministry of Labour imposes fines or other punishment in favour of the workers. There are suspected "sweat shop" conditions in the maquila sector. Especially lack of ventilation (problem relating to dust and heat), and to a lesser extend the lack of bathrooms, drinking water, and eating facilities, were a problem in this sector.

2000: Ratification of ILO Convention 182 on the worst forms of child labour (June $15^{\text {th }}$ ). Labour Code and Constitution require government to ensure that employees are not placed at risk in their workplaces. Health and safety regulations is outdated and enforcement is inadequate. Some maquilas workers were concerned with 'unhealthy drinking water, unsanitary bathrooms, and eating facilities, and inadequate ventilation'.

2001: Labour Code and Constitution require government to ensure that employees are not placed at risk in their workplaces. Health and safety regulations is outdated and enforcement is inadequate. Some maquilas workers were concerned with 'unhealthy drinking water, unsanitary bathrooms, and eating facilities, and inadequate ventilation'. May 9, NLC made public a 2000 report of the ministry of labour on conditions in the maquila sector. The report mentions failure to provide basic safety equipment and mandatory overtime policies. Some factories have 
unrealistic quotas for production and workers are required to put in extra hours when they fall short of the quota. (And the report describes systematic violation of the workers' efforts to form unions.)

2002: Labour Code and Constitution require government to ensure that employees are not placed at risk in their workplaces. Health and safety regulations is outdated and enforcement is inadequate. Some maquilas workers were concerned with 'unhealthy drinking water, unsanitary bathrooms, and eating facilities, and inadequate ventilation'.

\section{Brief historical/political overview:}

\section{AMNESTY INTERNATIONAL:}

1989: Alfredo Cristiani is inaugurated for five year term. Government's refusal to postpone elections to allow FMLN participation is met by a spate of killings of high level government and military officials. November $11^{\text {th }}$ talks between government and rebels fail. Rebels launch new offensive. Followed by declaration of a state of siege and a heavy counterattack. The state of siege allows for an increase in politically motivated arrests. Under the state of siege the period detainees can be held in police custody before being brought before a judge is increased from 72 hours to 15 days.

1990: State of siege ends in April 1990. In March most of those arrested under the state of siege are released. New talks with the FMLN take place under the auspices of the U.N. A declaration on human rights is signed. The Declaration obliges the parties to take steps to prevent, extrajudicial executions, torture, and 'disappearances'. However the talks are not completed by the end of the year and the FMLN renews fighting in the last two months of the year.

1991: The Act of New York is signed on 31 December. The Act includes data for a ceasefire and for the signing of an official peace accord. The New York Act is preceded by earlier agreements on military, judicial and socio-economic reforms. Constitutional changes lead to reform of the judiciary. A National Bureau for a Human Rights Ombudsman is proposed. However this bureau has not been set up by year's end. Constitutional changes leading to reform of police and military are not yet endorsed by the Legislative Council. In April the Truth Commission is set up. A mission of the U.N. (ONUSAL) is set up to monitor compliance with the human rights Declaration. In March council elections and elections for the Legislative Council are held. The elections were marred with irregularities. ARENA (the ruling rights wing party) loose their absolute majority. Despite peace talks there were great numbers of civilian and military casualties.

1992: On January 16 the Government and the FMLN sign peace accords ending 11 year old civil war. On December $15^{\text {th }}$ the conflict officially ended. Though realisation of the peace accords is slow, compliance on key elements is achieved. The FMLN is dismantled and changed into a political party. In February the Ombudsman for Human Rights is installed. However the Bureau is often confronted with death threats. Two days after official instalment an employee is paralysed in an attack. The steps taken to get those accused of human rights abuses convicted are undermined by the Law on National Reconciliation, which gives amnesty to all those not mentioned in the Truth Commission's Report. ONUSAL continues to monitor compliance with the Human Rights Declaration. Despite the peace accords there was an increase in the number of violent deaths.

\section{STATE DEPARTMENT:}

1989: El Salvador has a freely elected democratic government and an independent judiciary. On June 1 following free and fair elections civilian control of the government passed from one party to another. This was the first time in history. Alfredo Christiani of ARENA assumes the Presidency. In 1989 the FMLN pursues a campaign to make the country ungovernable. FMLN attempted to get an unconstitutional delay of the March elections and refused a cease fire proposal. Two cease fire proposals by FMLN were refused. After a number of meetings between FMLN and the government, the FMLN launched a new offensive on November 11. 
Following the FMLN offensive detainees can be held in police custody before being brought before a judge is increased from 72 hours to 15 days.

1990: Fewer human rights violations.

1991: On December 31 an agreement is signed by the Government and the FMLN effectively ending the 11 year war. The agreement provides for reintegration of FMLN combatants, constitutional reforms (human rights, judicial and electoral reforms), the formation of a truth commission and an ad-hoc commission charged with evaluating the human rights record, professional competence, and commitment to democracy of each ESAF officer. In addition a UN mission (ONUSAL) begins its work of verifying the human rights accord signed in July 1990 by the government and the FMLN.

1992: On 16 January an accord is signed to formalize the end of the conflict. On 1 February a cease fire officially takes effect. On 15 December full demobilization of the FMLN is realized. As part of the peace accords the Government and the FLMN agree on constitutional reforms, such as human rights reforms, judicial, and electoral reforms. These reforms are approved by the Legislative Assembly. The Truth Commission starts its work but has not yet reported. The Ad Hoc Commission gives its confidential report to the President and the UN Secretary General. The military is already being reorganized and trained.

1993: On March 15 the truth commission reports its findings. The Commission recommends all those identified as human rights violators be removed from government and military posts. and reforms in the military and the judiciary. However the National Assembly approves amnesty from criminal prosecution for all those implicated in the report. FMLN is completely dismantled. ESAF officer corps is cleared of human rights violators by ad-hoc commission.

1994: June 1 Armando Calderon Sol is elected president. FMLN are competing for the first time (the major opposition party). Both warring fractions have complied with the key measures in the peace accords. Human rights abuses declined significantly during the year. Judicial reform made some headway.

1995: Demobilization of military-dominated national police is completed. Complaints against ESAF continued to decline significantly.

1996: Human rights record improved.

1997: Human rights situation improved somewhat. United Nations special representative eliminated. Effectiveness of human rights ombudsman limited and hindered by further shrinking budget. New legislation takes effect (New Criminal Procedures Code and the new Penitentiary (Sentencing) Code). Government seeks to improve conditions in prisons as a reaction to 1996 PDDH report. PDDH and NGO's launch child awareness campaign.

1998: Human rights situation improved somewhat. Prosecution of Police officers accused of abuses had mixed results.

1999: Francisco Flores is elected President, and begins his term in June. Government's record on human rights improved somewhat.

2000: Ratification of ILO Convention 182 on the worst forms of child labour (June $15^{\text {th }}$ ).

2001: Two earthquakes (January and February) killed 1,100 persons and left 1,2 million people homeless, and caused over 1.3 Billion dollars in damage. It resulted in a 5-7 year fallback for the country (for example, more people living in poverty). In January the official currency changed to the dollar.

\footnotetext{
${ }^{1}$ Until 1992 El Salvador was the scene of a civil war between government forces (ESAF) and a guerrilla movement (FMLN). The guerrilla forces were responsible for numerous human rights abuses, such as extrajudicial killings, torture and forced labour. However these violations will not be mentioned in this table.

${ }^{2}$ Following a directive by Secretary of State Warren Christopher some changes in reporting were made as of the 1993 report. The changes include a stronger emphasis on prison conditions and a new section on "discrimination based on race, sex, religion, disability, language or social status. This new section also includes a paragraph on discrimination against children.

${ }^{3}$ There were many extrajudicial executions (though only a few are mentioned), amongst which the killing of six Jesuit priests, the house maid and her daughter. There also were a great number of political murders (incomplete figures indicate an average of 17 murders per month).

${ }^{4}$ Many were tortured, though the report emphasises this is not government policy.
} 
${ }^{5}$ Children under the age of 14 are prohibited from working. Exception may be made for instances in which work is absolutely indispensable to sustain the minor and his family. To this effect children under 14 often work on the family farm.

${ }^{6}$ Difficult to verify how many people were killed. Death squads were responsible for 45 deaths between January and June according to AI.

${ }^{7}$ It is impossible to discern an exact number of cases of torture or a pattern of torture. The report says: "In 1990 there continued to be credible reports of torture and abuse of some detainees by the public security forces and the military".

${ }^{8}$ Children under the age of 14 are prohibited from working. Exception may be made for instances in which work is absolutely indispensable to sustain the minor and his family. To this effect children under 14 often work on the family farm.

${ }^{9}$ It is difficult to read a number into the report. The report states several people were executed, In addition to that the report mentions the U.N. special rapporteur's remarks on the difficulty in attributing murders to death squads. A number of such murders took place during the year.

${ }^{10}$ The report simply states that torture continued.

${ }^{11} 400$ cases of rape were registered between January and July in San Miguel (the third largest city in the country). The majority of those rape victims were children.

${ }^{12}$ Children under the age of 14 are prohibited from working. Exception may be made for instances in which work is absolutely indispensable to sustain the minor and his family. To this effect children under 14 often work on the family farm.

${ }^{13}$ The report is unclear about the number of extrajudicial executions. It simply states there were less than the previous year and that there were no known death squad related murders.

${ }^{14}$ The report simply states that torture continued.

${ }^{15}$ Children under the age of 14 are prohibited from working. Exception may be made for instances in which work is absolutely indispensable to sustain the minor and his family. To this effect children under 14 often work on the family farm. Children often work as vendors and general labourers in small businesses, especially in the informal sector.

${ }^{16}$ Military personnel often acting in the guise of Death Squads made many trade unionists and academics 'disappear'. A clear allusion is made to link disappearance to extrajudicial executions. Moreover government forces or death squads were responsible for over sixty killings of trade unionists, academics, members of political parties, and others apparently targeted on account of their opposition to government policies.

17 Torture is routine. Many political detainees, trade unionists and academics were tortured to extract 'confessions'. Reports of torture increased during the state of siege.

${ }^{18}$ In October AI published a report entitled: "El Salvador: Killings, Torture and 'Disappearances'."

${ }^{19}$ The number of deaths through death squads more than doubled. Many people were killed by security forces, especially in rural areas. A number of people who were arrested by soldiers were secretly sentenced to death and executed. (FMLN accused of killing detainees, thought to be informers.)

${ }^{20}$ Especially during incommunicado detention. Torture was most likely to happen before official recognition of the arrest.

${ }^{21}$ A number of people were executed by security forces, especially election candidates and rural communities were targeted. About 35 murders were ascribed to death squads. It is strongly believed these death squads have ties with governmental forces. The number of 'disappearances' was significantly reduced.

${ }^{22}$ The use of incommunicado detention facilitated the use of torture.

${ }^{23}$ There were a number of deaths that could be directly attributed to security forces. At least 35 died at the hands of 'death squads'. There were no more 'disappearances'. (A number of people were executed by the FMLN.)

${ }^{24}$ There was a sharp reduction in the number of cases of torture, however there still were a number of cases.

${ }^{25}$ Children under 14 often work on the family farm.

${ }^{26}$ It is difficult to ascertain the number of extrajudicial executions. The exact phrase used by the State Department is: "The end of hostilities (...) led to an immediate and significant reduction in extrajudicial killings." An example of possible extrajudicial executions is the death of a demonstrator. This is followed by an enumeration of killings that could be labelled extrajudicial and that could have been perpetrated by death squads. The existence of death squads is not acknowledged, but each enumerated murder is followed by the suggestion that the murder is very reminiscent of the 80's in which death squads were fully operative.

${ }^{27}$ Six confirmed cases.

${ }^{28}$ Prison conditions are bleak. There is severe overcrowding, lack of bedding and lack of food.

${ }^{29}$ Hospitals receive between 4 or 5 cases of sexually abused children per day. Abandonment is also a great problem.

${ }^{30}$ Children under 14 often work on the family farm. Children also frequently work as vendors and general labourers in small businesses, especially in the informal sector. Poverty forces many children to quit school too early.

${ }^{31}$ In prisons. And child malnutrition is a great problem.

${ }^{32}$ ONUSAL confirmed five extrajudicial executions. ONUSAL were still investigating a number of (politically motivated) murders. ONUSAL confirmed that there was a decline of extrajudicial killings between 1993 and 1994.

${ }^{33}$ Three reports of torture.

${ }^{34}$ Prison conditions are bleak. There is severe overcrowding, lack of bedding and lack of food. 
${ }^{35}$ Abuse took place in all forms, that is physical, sexual, abandonment, exploitation, and neglect. The problem has taken on greater forms.

${ }^{36}$ Children under 14 often work on the family farm. Children also frequently work as vendors and general labourers in small businesses, especially in the informal sector. Poverty forces many children to quit school too early. Labour exploitation is a growing problem. Approx. 270,000 children work up to 12 hours a day.

${ }^{37}$ In prisons. And child malnutrition is a problem.

${ }^{38}$ Prison conditions are bleak. There is severe overcrowding, lack of bedding and lack of food.

${ }^{39}$ Abuse took place in all forms, that is physical, sexual, abandonment, exploitation, and neglect. The problem has again taken on greater forms.

${ }^{40}$ Children under 14 often work on the family farm. Children also frequently work as vendors and general labourers in small businesses, especially in the informal sector. Poverty forces many children to quit school too early. Labour exploitation is a growing problem.

${ }^{41}$ Approx. 1200 minors live in the streets of San Salvador. The problem is growing. Protection is lacking.

${ }^{42}$ Approx. 50\% of all infants under 5 are undernourished.

${ }^{43}$ There were two cases in which authorities charged PNC officers with extrajudicial killing.

44 Severe overcrowding was reduced somewhat, but conditions remained poor. The ombudsman stated the situation in prisons constituted 'a systematic violation of human rights'. Inmate violence is a grave problem.

${ }^{45}$ Abuse took place in all forms, that is physical, sexual, abandonment, exploitation, and neglect. The problem has again taken on greater forms. Especially the problem of sexual abuse is acute.

${ }^{46}$ Most of the 270,000 working minors are street vendors. They loose the opportunity to education and are vulnerable for sexual abuse and exploitation as prostitutes.

${ }^{47}$ An estimated 2,000 street children in San Salvador.

48 \% of infants under 5 are undernourished.

${ }^{49}$ It is difficult to obtain the exact number, if any, of cases of torture. The report states that the PDDH (office of the Ombudsman) received 993 complaints of violation of the right of personal integrity (a category which covers torture, inhuman or degrading treatment, mistreatment, disproportionate use of force, and improper treatment of detainees).

${ }^{50}$ Overcrowding worsened.

${ }^{51}$ Abuse took place in all forms, that is physical, sexual, abandonment, exploitation, and neglect. The problem has again taken on greater forms. Especially the problem of sexual abuse is acute.

${ }_{52}$ Most of the 270,000 working minors are street vendors. They loose the opportunity to education and are vulnerable for sexual abuse and exploitation as prostitutes.

${ }^{53}$ There are no reliable estimates as to the number of street children, but it is a sizable number.

${ }^{54} 50 \%$ of infants under 5 are undernourished.

55 State Department is somewhat inconsistent. In the introduction of the report (which also contains a summarized overview of human rights abuses) State Department states that there were two extrajudicial executions during the year. However in the complete overview of abuses in Section 1, under a ('Political and other Extrajudicial Killing') the report states that there 'were two cases of suspected extrajudicial executions' (emphasis added.)

${ }^{56}$ It is difficult to obtain the exact number, if any, of cases of torture. The report states that the PDDH (office of the Ombudsman) received 849 complaints of violation of the right of personal integrity (a category which covers torture, inhuman or degrading treatment, mistreatment, disproportionate use of force, and improper treatment of detainees).

57 There was better food, medical care was improved and there was a little less overcrowding (this due to the effects of the new sentencing and penal codes in April 1998). However overcrowding was still severe. Gang violence is a great problem.

${ }^{58}$ Not all rural areas could provide education until ninth grade to all students. $34 \%$ of rural children and $17 \%$ of urban children did not attend classes.

${ }^{59}$ Abuse took place in all forms, that is physical, sexual, abandonment, exploitation, and neglect. Government is working closely with UNICEF. There were more cases of sexual abuse than in 1997.

${ }^{60}$ Most of the 270,000 working minors are street vendors. They loose the opportunity to education and are vulnerable for sexual abuse and exploitation as prostitutes. A November study concluded that the main reasons for child prostitution were 'poverty, lack of a strong nuclear family, discrimination against women, and organized crime.' Another study revealed the two main reasons to be poverty and family problems. There are reports that children are forced into prostitution.

${ }^{61}$ There are an estimated 1000 children living on their own in the streets. $42 \%$ of these children are under the age of 5. Children's rights organisations accuse the PNC of brutality against street children.

${ }^{62}$ Infant malnutrition is a problem. 1998 World Food Program indicated that $12 \%$ of children under 5 suffer from grave malnutrition, an additional $38 \%$ suffer from less severe malnutrition. The Government has a national plan to tackle the problem.

${ }^{63}$ There were seven cases of reported extrajudicial executions.

${ }^{64}$ It is difficult to obtain the exact number, if any, of cases of torture. The report states that the PDDH (office of the Ombudsman) received 929 complaints of violation of the right of personal integrity (a category which covers torture, inhuman or degrading treatment, mistreatment, disproportionate use of force, and improper treatment of detainees).

${ }^{65}$ Prison conditions were poor, but improved significantly. There was better food and better medical care. As a result of the 1997 and 1998 implementing of new penal and sentencing laws, the population dropped by $23 \%$. 
${ }^{66}$ Not all rural areas could provide education until ninth grade to all students.

${ }^{67}$ Abuse took place in all forms, that is physical, sexual, abandonment, exploitation, and neglect. Government is working closely with UNICEF. There was an increase in cases of abuse.

${ }^{68}$ Most of the 270,000 working minors are street vendors. They loose the opportunity to education and are vulnerable for sexual abuse and exploitation as prostitutes. A study concluded that the main reasons for child prostitution were 'poverty, lack of a strong nuclear family, discrimination against women, and organized crime.' Another study revealed the two main reasons to be poverty and family problems. There are reports that children are forced into prostitution. The Government has initiated and participated in a number of programs to combat the problems of child labour. Interpol stated that some 20 Salvadorian girls had been taken from prostitution rings in the last three years. There were reports that children had been brought in from neighbouring countries and forced to beg.

${ }^{69}$ There are an estimated 1000 children living on their own in the streets. $42 \%$ of these children are under the age of 5. Children's rights organisations accuse the PNC of brutality against street children.

${ }^{70}$ Malnutrition decreased, but remained a problem. The Government has a national plan to tackle the problem.

${ }^{71}$ The exact number of extrajudicial killings is not available, but the report states 'the police committed some extrajudicial executions'.

${ }^{72}$ At least one case of alleged torture. The report states that the PDDH (office of the Ombudsman) received 724 complaints of violation of the right of personal integrity (a category which covers torture, inhuman or degrading treatment, mistreatment, disproportionate use of force, and improper treatment of detainees). The number is significantly lower than that of 1999. Moreover a commission set up by the President recommended certain changes in the procedure to investigate alleged abuses by the PNC. The recommendations were put into action. The commission also identified 14 persons suspected of having committed torture in 2000 and prior years.

${ }^{73}$ Overcrowding was reduced, but some facilities still suffered from some overcrowding. Gang related violence remained a great problem.

${ }^{74}$ Not all rural areas could provide education until ninth grade to all students. $27 \%$ of rural children and $14 \%$ of urban children did not attend classes.

${ }^{75}$ Abuse took place in all forms, that is physical, sexual, abandonment, exploitation, and neglect. Government is working closely with UNICEF. There was a decrease in figures showing the various forms of abuse.

${ }^{76}$ Most of the 270,000 minors work, work as street vendors. They loose their opportunity to an education, often fall victim to sexual abuse and are exploited and forced into prostitution. Children, especially those living on the street, are trafficked to other countries and forced into prostitution. Children from Honduras have also been used as beggars to support traffickers in San Salvador. El Salvador is a source of women and children for trafficking in prostitution to Mexico and other countries.

${ }_{77}^{7.1 \%}$ of infants under 5 suffer from grave malnutrition, an additional $21 \%$ experience less severe malnutrition.

${ }^{78}$ Post conflict violence.

${ }^{79}$ Not only has the title of the first paragraph of the first section been changed from "Political and Other Extrajudicial Killing" to "Arbitrary and Unlawful Deprivation of Life", but police killings are no longer indicated as extrajudicial executions or reports thereof, but are merely called 'killings'. There were some "police killings".

${ }^{80}$ Overcrowding was reduced, but some facilities still suffered from some overcrowding. Gang related violence remained a great problem.

${ }^{81}$ Same data as previous year. Government estimates that about 150,000 children were prevented from going to school, because of economic hardship and damage to the school buildings caused by the January and February earthquakes.

${ }^{82}$ Abuse took place in all forms, that is physical, sexual, abandonment, exploitation, and neglect. Government is working closely with UNICEF. There was a decrease in figures showing the various forms of abuse (though some NGO's do not agree).

${ }^{83}$ UNICEF estimates that there Are 185,000 minors working. Mostly they work for the family (peasants) or as street vendors. They loose their opportunity to an education. Children, especially those living on the street, are trafficked to other countries and forced into prostitution. Children from Honduras have also been used as beggars to support traffickers in San Salvador. El Salvador is a source of women and children for trafficking in prostitution to Mexico and other countries.

${ }^{84} 19 \%$ of children suffer from chronic malnutrition.

${ }^{85}$ The police committed some "killings". The PDDH received 30 complaints of attempted and/or completed unlawful killings by police during the year.

${ }^{86}$ Prison conditions were poor. Overcrowding continued. Gang violence is a problem.

${ }^{87}$ One case of torture. The report states that the PDDH (office of the Ombudsman) received 766 complaints of violation of the right of personal integrity (a category which covers torture, inhuman or degrading treatment, mistreatment, disproportionate use of force, and improper treatment of detainees), compared with 736 in 2001. Most of these cases were classified as mistreatment.

${ }^{88}$ In rural areas 14 percent of primary school aged children (7-11 years) an 32 percent of sixth to eighth grade aged children (12-14 years) did not attend school. Only 7 percent of children in rural areas attended school in grades 6 to 8 .

${ }_{89}$ Abuse took place in all forms, that is physical, sexual, abandonment, exploitation, and neglect. Government is working closely with UNICEF. According to ISNA (an autonomous entity) there were 842 cases of physical mistreatment, 454 cases of negligence, and 446 cases of abandonment, compared 916 cases of physical mistreatment, 366 cases of negligence, and 573 cases of abandonment reported in 2001. Using different criteria, 
the ISDEMU recorded 1,694 cases of abuse during the year compared with 1,196 in 2001. ISNA reported 173 cases of sexual abuse during the year compared with 115 in 2001.

${ }^{90} 75,000$ children between the ages of 5 and 13 worked, as did almost 147,000 children between the ages of 14 and 17. The Ministry can give special permission for children to work, when such employment is indispensable to the work during harvesting and planting seasons. Child labour in the informal sector is difficult to monitor. Children, especially those living on the street, are trafficked to other countries and forced into prostitution. Child prostitution is a problem. UNICEF reported that between 10 and 25 percent of visible prostitutes were minors, and 40 percent of the hidden prostitutes are minors. El Salvador is a source of women and children for trafficking in prostitution to Mexico and other South American countries.

${ }^{91}$ Some juvenile detention centres were found to be holding adults as well as juveniles. Some adult detention centres were found to be holding juveniles. Gang violence is a major problem in juvenile detention centres.

$9219 \%$ of children suffer from chronic malnutrition. 


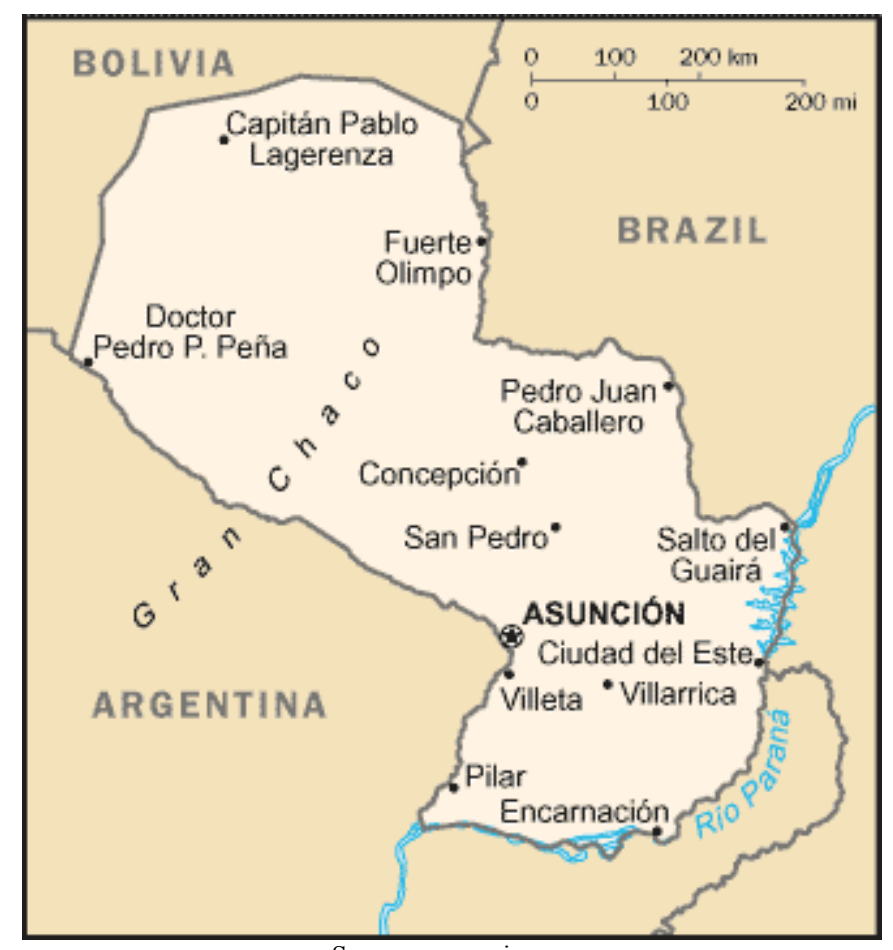

Source: www.cia.gov

\section{PARAGUAY}

(population: 6,036,900)

\begin{tabular}{|c|c|c|c|c|}
\hline & 1989 & 1990 & 1991 & 1992 \\
\hline $\begin{array}{c}\text { Political } \\
\text { Terrorscale }\end{array}$ & $2 / 2$ & $3 / 2$ & $2 / 3$ & $2 / 3$ \\
\hline \multicolumn{5}{|l|}{ Conflict Level } \\
\hline $\begin{array}{c}\text { Freedom } \\
\text { House }\end{array}$ & $4 / 3 / \mathrm{PF}$ & $4 / 3 / \mathrm{PF}$ & $3 / 3 / \mathrm{PF}$ & $3 / 3 / \mathrm{PF}$ \\
\hline $\begin{array}{c}\text { U.S. State } \\
\text { Department }^{1}\end{array}$ & $(\mathrm{e})^{2}, \mathrm{t}^{3}, \mathrm{CL}^{4},(\mathrm{FE})^{5}$ & $\begin{array}{l}(\mathrm{e})^{6}, \mathrm{t}^{7}, \mathrm{AE}^{8}, \mathrm{CL}^{9}, \\
\mathrm{DH}^{10},(\mathrm{FE})^{11}\end{array}$ & $\begin{array}{c}\mathrm{e}^{12}, \mathrm{t}^{13}, \mathrm{AE}^{14}, \mathrm{CL}^{15} \\
\mathrm{DH}^{16},(\mathrm{FE})^{17}\end{array}$ & $\begin{array}{r}\mathrm{e}, \mathrm{p}^{18}, \mathrm{~T}^{19}, \mathrm{AE}^{20} \\
\mathrm{CL}^{21}, \mathrm{DH}^{22},(\mathrm{FE})^{23}, \\
\mathrm{IF}^{24}\end{array}$ \\
\hline $\begin{array}{c}\text { Amnesty } \\
\text { International }\end{array}$ & $(\mathrm{e})^{25},(\mathrm{FE})^{26}$ & $\mathrm{~T}^{27},(\mathrm{FE})^{28}$ & $\mathrm{t}^{29},(\mathrm{FE})^{30}$ & $\mathrm{t}^{31}$ \\
\hline
\end{tabular}

\begin{tabular}{|c|c|c|c|c|}
\hline & 1993 & 1994 & 1995 & 1996 \\
\hline $\begin{array}{c}\text { Political } \\
\text { Terrorscale }\end{array}$ & $2 / 3$ & $3 / 2$ & $3 / 2$ & $3 / 3$ \\
\hline \multicolumn{5}{|l|}{ Conflict Level } \\
\hline $\begin{array}{c}\text { Freedom } \\
\text { House }\end{array}$ & $3 / 3 / \mathrm{PF}$ & $4 / 3 / \mathrm{PF}$ & $4 / 3 / \mathrm{PF}$ & $4 / 3 / \mathrm{PF}$ \\
\hline $\begin{array}{c}\text { U.S. State } \\
\text { Department }\end{array}$ & 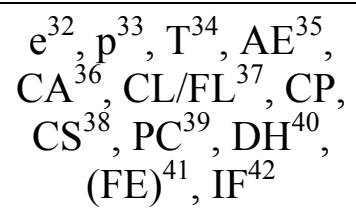 & $\begin{array}{c}\mathrm{e}^{43}, \mathrm{p}^{44}, \mathrm{~T}^{45}, \mathrm{AE}^{46}, \\
\mathrm{CA}^{47}, \mathrm{CL}^{4} / \mathrm{FL}^{48}, \mathrm{CP}, \\
\mathrm{CS}^{49}, \mathrm{PC}^{50}, \mathrm{DH}^{51}, \\
(\mathrm{FE})^{52}, \mathrm{IF}^{53}\end{array}$ & $\begin{array}{l}(\mathrm{e})^{54}, \mathrm{p}^{55}, \mathrm{~T}^{56}, \mathrm{AE}^{57}, \\
\mathrm{CA}^{58}, \mathrm{CL}^{2} \mathrm{FL}^{59}, \mathrm{CP} \\
\mathrm{CS}^{60},(\mathrm{FE})^{61}, \mathrm{IF}^{62}\end{array}$ & $\begin{array}{l}(\mathrm{e})^{63}, \mathrm{P}^{64}, \mathrm{~T}, \mathrm{AE}^{65}, \\
\mathrm{CA}^{66}, \mathrm{CL}^{-} \mathrm{FL}^{67}, \mathrm{CP}, \\
\mathrm{CS},(\mathrm{FE})^{68}, \mathrm{IF}^{69}\end{array}$ \\
\hline
\end{tabular}




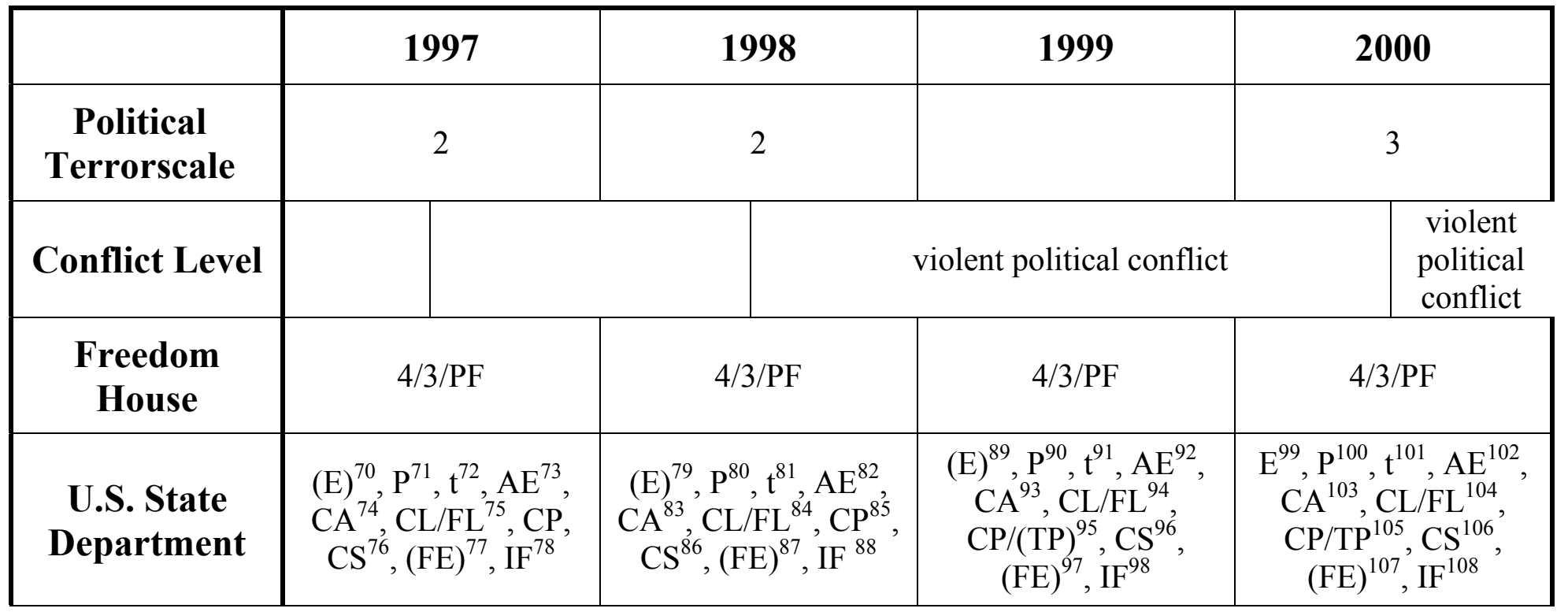

\begin{tabular}{|c|c|c|c|}
\hline & \multicolumn{2}{|c|}{2001} & 2002 \\
\hline \multicolumn{4}{|l|}{$\begin{array}{c}\text { Political } \\
\text { Terrorscale }\end{array}$} \\
\hline Conflict Level & $\begin{array}{l}\text { violent } \\
\text { political } \\
\text { conflict }\end{array}$ & \multicolumn{2}{|c|}{ violent political conflict } \\
\hline $\begin{array}{l}\text { Freedom } \\
\text { House }\end{array}$ & \multicolumn{2}{|c|}{$4 / 3 / \mathrm{PF}$} & $4 / 3 / \mathrm{PF}$ \\
\hline $\begin{array}{c}\text { U.S. State } \\
\text { Department }\end{array}$ & $\begin{array}{r}\mathrm{E}^{109}, \mathrm{P}^{110} \\
\mathrm{CA}^{113}, \\
\mathrm{CP} / \mathrm{TP}^{11} \\
\mathrm{IF}\end{array}$ & $\begin{array}{l}\mathrm{AE}^{112} \\
114 \\
116\end{array}$ & \\
\hline
\end{tabular}

\section{Working conditions:}

1989: The nascent trade union movement has yet to focus on occupational health and safety. That coupled with the slowness and relative expense of the labour law system, resulted in frequent failure to protect workers. Existing laws were inadequately enforced, due partially to a lack of inspectors.

1990: There was inadequate enforcement of safety and hygiene provisions of the Labour Code, this was partly due to a lack of inspectors.

1991: There was inadequate enforcement of safety and hygiene provisions of the Labour Code, this was partly due to a lack of inspectors.

1992: There was inadequate enforcement of safety and hygiene provisions of the Labour Code, this was partly due to a lack of inspectors.

1993: There was inadequate enforcement of safety and hygiene provisions of the Labour Code, this was partly due to a lack of inspectors.

1994: _There was inadequate enforcement of safety and hygiene provisions of the Labour Code, this was partly due to a lack of inspectors. Subsequently the labour movement sponsored inspector training programs. Workers do not have the right to remove themselves from situations which endanger health and safety without 'jeopardy to their continued employment'. Workers are protected by law when they file complaints about such conditions, but many employers did take disciplinary actions against the employee with impunity. 
1995: There was inadequate enforcement of safety, hygiene and comfort provisions of the Labour Code, this was partly due to a lack of inspectors. Subsequently the labour movement sponsored inspector training programs. Workers do not have the right to remove themselves from situations which endanger health and safety without 'jeopardy to their continued employment'. Workers are protected by law when they file complaints about such conditions, but many employers did take disciplinary actions against the employee with impunity.

1996: There was inadequate enforcement of safety, hygiene and comfort provisions of the Labour Code, this was partly due to a lack of inspectors. Subsequently the labour movement sponsored inspector training programs. Workers have the right to remove themselves 'from situations that endanger health or safety' without losing their job, but these conditions first have to be recognised by the Ministries of labour and health. Workers who file complaints on the conditions are protected by law, but employers often take disciplinary action against them. 1997: There was inadequate enforcement of safety, hygiene and comfort provisions of the Labour Code, this was partly due to a lack of inspectors and other resources. The Ministry sponsored 'the reconvening of a tripartite group of government, labour, and employers' in order to update the labour manual and to start a program which should expand 'transparency in the labour inspections process'. Workers have the right to remove themselves 'from situations that endanger health or safety' without losing their job, but these conditions first have to be recognised by the Ministries of labour and health. Workers who file complaints on the conditions are protected by law, but employers often take disciplinary action against them.

1998: There was inadequate enforcement of safety, hygiene and comfort provisions of the Labour Code, this was partly due to a lack of inspectors and other resources. The Ministry sponsored 'the reconvening of a tripartite group of government, labour, and employers' in order to update the labour manual and to start a program which should expand 'transparency in the labour inspections process'. On April 30, the new manual was approved by the Ministries of Justice and Labour, for the use by inspectors. 2,000 new manuals were distributed. Workers have the right to remove themselves 'from situations that endanger health or safety' without losing their job, but these conditions first have to be recognised by the Ministries of labour and health. Workers who file complaints on the conditions are protected by law, but employers often take disciplinary action against them.

1999: There was inadequate enforcement of safety, hygiene and comfort provisions of the Labour Code, this was partly due to a lack of inspectors and other resources. The Ministry sponsored 'the reconvening of a tripartite group of government, labour, and employers' in order to update the labour manual and to start a program which should expand 'transparency in the labour inspections process'. Subsequently the manual was updated. Workers have the right to remove themselves 'from situations that endanger health or safety' without losing their job, but these conditions first have to be recognised by the Ministries of labour and health. Workers who file complaints on the conditions are protected by law, but employers often take disciplinary action against them.

2000: There was inadequate enforcement of safety, hygiene and comfort provisions of the Labour Code, this was partly due to a lack of inspectors and other resources. Workers have the right to remove themselves 'from situations that endanger health or safety' without losing their job, but these conditions first have to be recognised by the Ministries of labour and health. Workers who file complaints on the conditions are protected by law, but employers often take disciplinary action against them.

2001: There was inadequate enforcement of safety, hygiene and comfort provisions of the Labour Code, this was partly due to a lack of inspectors and other resources. Workers have the right to remove themselves 'from situations that endanger health or safety' without losing their job, but these conditions first have to be recognised by the Ministries of labour and health. Workers who file complaints on the conditions are protected by law, but employers often take disciplinary action against them. 


\section{Brief historical/political overview:}

\section{$\underline{\text { Amnesty International: }}$}

1989: General Alfredo Stroessner is overthrown in February after a successful military coup led by General Andrés Rodríguez. Stroessner seeks asylum in Brazil. Rodríguez forms a provisional government, which is largely composed of civilians. He starts to purge the armed forces. The Government brings about important human rights guarantees. In May Rodriguez is elected President and the Colorado Party wins in Presidential and congressional elections. The elections are marred by widespread irregularities. A congressional human rights commission is created in order to oversee judicial steps taken against those accused of torturing or ill-treating detainees. Investigations are started into crimes committed under the previous regime. Illtreatment and illegal detention is often the consequence of land- and trade union disputes.

1990: A law that would enable the commission created in 1989 to start its work is blocked by President Rodríguez. Investigations into crimes committed under the previous regime continued, but hardly made any progress.

1991: Investigations into past violations continued to make very slow progress.

1992: New constitution guarantees right to life and forbids the death penalty for 'ordinary crimes'. Investigations into past violations continued to make very slow progress, but there was one case in which five high ranking officers were sentenced to prison terms.

\section{State Department:}

1989: In early 1989 a new government committed itself to a transition to democracy and respect of human rights. It subsequently took important steps towards this goal. On February 2 General Andres Rodriguez overthrew the 34-year old dictatorship of General Alfredo Stroessner. On May 1, General Rodriguez was given a mandate to lead the country to democracy, in elections that were generally seen as relatively free and fair. The army and the ruling Colorado party remained the principal sources of power. Human rights concerns shifted from more basic to more complicated issues.

1991: Elections for municipal authorities and constitutional convention delegates were considered free and fair.

1992: A new constitution passed in June is an important step towards civilian rule, judicial independence, and political accountability.

1993: In May Juan Carlos Wasmosy becomes the nation's first freely elected civilian President. 1994: The Government begins convicting and punishing police officials who committed serious human rights abuses.

1995: Nine-member supreme court is installed in April, in order to reform the judicial system. Government's human rights record improved somewhat. The Government continues to convict and punish those who committed human rights abuses during the Stroessner area. (Traffic in babies was a serious problem).

1996: The Supreme Court completely restaffs judicial and prosecutorial positions during the year. In April an attempted coup by the then army commander, General Lino Oviedo, fails. The Government continues to convict and punish those who committed human rights abuses during the Stroessner area.

1997: Lino Oviedo (coup leader in previous year) is elected by the Colorado Party to become potential contender in the May 1998 elections. Human rights record improve somewhat. The Government continues to convict and punish those who committed human rights abuses during the Stroessner area. (Effective steps are taken, like the 1995 moratorium on international adoptions, to tackle the problem of trafficking in babies).

1998: Raul Cubas Grau of the Colorado Party becomes President. The original Colorado Party candidate, Lino Oviedo, is disqualified as a candidate, because he is convicted by a military court of sedition and rebellion. Once Raul Cubas Grau takes office he issues a decree ordering the release of Oviedo. However this decree is overturned by the Supreme Court. Cubas Grau issues another decree that 'simply noted the decision and ordered it to be filed'. He then sent the court's decision back to the, newly constituted (many pro-Oviedo officers), military court for review an implementation. This has cast a great shadow over the independence of the 
judiciary. Also rumours about coup plotting persisted and the changes brought about through the elections may influence the military apolitical status. Human rights record improve slightly. The Government continues to convict and punish those who committed human rights abuses during the Stroessner area. The Pinochet arrest in the United Kingdom focuses renewed attention on extrajudicial killings during the Stroessner era. It is alleged Stroessner took part in Operation Condor (the regional plan to eliminate leftists). New penal and criminal procedures codes entered into force, providing protection of fundamental human rights.

1999: The year is marked by growing tension. The Government tries to undercut the constitutional authority of the executive and the judiciary. On the other hand Congress and the Supreme court challenged the President for months. On March 23, Cobas foe and Vice President Luis Maria Argana is assassinated, allegedly by supporters of General Lino Oviedo (both Oviedo and Cubas are alleged to have been implicated in the assassination). On March 28 the President resigns before he can be impeached. He than flees the country. Senate President Luis Gonzalez Macchi assumes the Presidency. The succession was orderly. It is agreed the President will serve the full remainder of the term until 2003. A "National unity" government is formed uniting for the first time in 50 years the two main opposition parties. The Supreme Court continues reforms, but is still put under pressure by politicians and others. The Pinochet arrest in the United Kingdom focuses renewed attention on extrajudicial killings during the Stroessner era. It is alleged Stroessner took part in Operation Condor (the regional plan to eliminate leftists). New penal and criminal procedures codes entered into force, providing protection of fundamental human rights.

2000: In February the Liberal Party withdrew from the 'National Unity Government' weakening it in the process. The Colorado Party has a small majority, but the party has no unity and new alliances and coalitions need to made depending upon the issue at hand. On May 18 members of two army units and a group of National Police Officers tried to overthrow the President. The soldiers and police officers were loyal to former General Lino Oviedo. The coup lasted 1 day. The failed coup was followed one day later by the passing of an "unpopular state of exception" which allowed the Government to imprison those suspected of involvement in the coup attempt and limit public meetings and demonstrations. In August Julio Cesar Franco of the Liberal Party was voted Vice President. The Supreme Court continued the reform process. The new Penal and Criminal procedures code entered fully into force in March.

\footnotetext{
${ }^{1}$ Following a directive by Secretary of State Warren Christopher some changes in reporting were made as of the 1993 report. The changes include a stronger emphasis on prison conditions and a new section on "discrimination based on race, sex, religion, disability, language or social status. This new section also includes a paragraph on discrimination against children.

${ }^{2}$ Two strikers were killed by police, it is unclear in what circumstances it happened.

${ }^{3}$ Some isolated cases of torture.

${ }^{4}$ It is estimated 15,000 children, many younger than 12, work in the streets of Asuncion, selling newspapers, shining shoes, cleaning car windows, and so forth.

${ }^{5}$ Squatters (campesinos) were violently evicted from land.

${ }^{6}$ One person died in detention in unclear circumstances. Two peasants were killed in unclear circumstances.

${ }^{7}$ There were frequent and credible reports of police brutality, this included the use of torture. Thus it is difficult to say whether there were frequent reports of torture alone. However a number of examples of torture are given. Police also tortured minors.

${ }^{8}$ Koreans and Chinese do not have equal access to schools. Indigenous Indian community has poor quality education.

${ }^{9}$ It is estimated 25,000 children, many younger than 12 , work in the streets of Asuncion, selling newspapers, shining shoes, cleaning car windows, and so forth. In rural areas it is not unusual to have children as young as 10 to work beside their parents cutting sugar cane.

${ }^{10}$ Koreans and Chinese are discriminated against in housing.

${ }^{11}$ Landowners and police evicted peasants violently from their land.

12 There were a number of politically motivated killings and a number of extrajudicial deaths of people in custody (seven clear examples are given.

13 There were credible reports of torture, it is not known however whether torture is routine/systematic/widespread.

${ }^{14}$ Koreans and Chinese do not have equal access to schools.

${ }^{15}$ It is estimated 25,000 children, many younger than 12 , work in the streets of Asuncion, selling newspapers, shining shoes, cleaning car windows, and so forth. In rural areas it is not unusual to have children as young as 10 to work beside their parents cutting sugar cane.
} 
${ }^{16}$ Koreans and Chinese are discriminated against in housing.

${ }^{17}$ Landowners and police evicted peasants violently from their land.

${ }^{18}$ Overcrowding and police brutality and abuse were the main problems.

${ }^{19}$ Torture of criminal suspects is common. Minors are particularly susceptible to abuse.

${ }^{20}$ Koreans and Chinese do not have equal access to schools. Indigenous Indian community has poor quality education.

${ }^{21}$ Many thousands of children, many younger than 12, work in the streets of Asuncion, selling newspapers, shining shoes, cleaning car windows, and so forth. In rural areas it is not unusual to have children as young as 10 to work beside their parents cutting sugar cane.

${ }^{22}$ Koreans and Chinese are discriminated against in housing.

${ }^{23}$ Landowners and police evicted peasants violently from their land.

${ }^{24}$ Indigenous people suffer from malnutrition.

${ }^{25}$ Two strikers were killed by police, it is unclear in what circumstances it happened.

${ }^{26}$ Many landless farmers started occupying land from, often absent, big landowners. These families were often forcibly evicted by police, army and civilians (allegedly paid by the landowners).

${ }^{27}$ Of evicted (and landless) farmers and minors.

${ }^{28}$ Many landless farmers started occupying land from, often absent, big landowners. These families were often forcibly evicted by police, army and civilians (allegedly paid by the landowners).

${ }^{29}$ It is clear there were a number of cases of torture, unclear is how many it were.

${ }^{30}$ Many landless farmers started occupying land from, often absent, big landowners. These families were often forcibly evicted by police, army and civilians (allegedly paid by the landowners). Moreover after eviction crops were often destroyed as well as property of the peasants.

${ }^{31}$ It is clear there were a number of cases of torture, unclear is how many it were.

${ }^{32}$ There were at least seven extrajudicial killings.

${ }^{33}$ There was overcrowding and much mistreatment of prisoners. The situation was most serious in Panchito Lopez youth prison. Buen Pastor prison (a women's prison) opened a new wing for minor girls, this improved the previously abysmal conditions.

${ }^{34}$ Juveniles were more likely to be tortured than adults.

${ }^{35}$ The majority of children working have no access to education. Young girls working as domestic servants or nannies are denied access to education. Eighty children of an indigenous community had no access to school.

${ }^{36}$ Young girls working as servants or nannies are mistreated by their employers. Minors are frequently mistreated and tortured in police custody. Koreans and Chinese do not have equal access to schools. Indigenous Indian community has poor quality education.

${ }^{37}$ There are up to 26,000 children working as street vendors, shoe shiners, or prostitutes. Young girls work as servants or nannies (also see AE and CA). Many thousands of children under the age of 12 work in the informal sector as shoe shiner, selling newspapers and sundries, and cleaning car windows. Many children in rural areas as young as 10 work in the field.

${ }^{38}$ Some minors were forced into obligatory military service before the age of 17.

${ }^{39}$ See ' $p$ ' and ' $T$ '.

${ }^{40}$ Koreans and Chinese are discriminated against in housing.

${ }^{41}$ Some landowners removed squatters violently.

${ }^{42}$ The majority of working children suffer from malnutrition. Indigenous people often suffer from malnutrition.

${ }^{43}$ Two extrajudicial killings.

${ }^{44}$ Prison conditions were poor. Overcrowding and mistreatment were the greatest problems. An independent investigation in Panchito Lopez youth prison revealed the institution was 'unsanitary, unsafe, and extremely overcrowded'. (the institution was originally built as a single family home, it houses 130 to 150 detainees). Tacumbu prison was found to be severely overcrowded. Two prisons in Alto Parana and Canindeyu were deemed 'inhuman' by a Brazilian NGO.

${ }^{45}$ Juveniles were more likely to be tortured than adults.

${ }^{46}$ The majority of children working have no access to education. Young girls working as domestic servants or nannies are denied access to education. Koreans and Chinese do not have equal access to schools. Indigenous Indian community has poor quality education.

${ }^{47}$ Young girls working as servants or nannies are mistreated by their employers. Minors are frequently mistreated and tortured in police custody.

${ }^{48}$ There are up to 26,000 children working as street vendors, shoe shiners, or prostitutes. Young girls work as servants or nannies (also see AE and CA). Many thousands of children under the age of 12 work in the informal sector as shoe shiner, selling newspapers and sundries, and cleaning car windows. Many children in rural areas as young as 10 work in the field.

${ }^{49}$ Some minors were forced into obligatory military service before the age of 17.

${ }^{50} \mathrm{See}$ ' $\mathrm{p}$ ' and ' $\mathrm{T}$ '.

${ }_{52}^{51}$ Koreans and Chinese are discriminated against in housing.

${ }^{52}$ Some landowners removed squatters violently.

${ }^{53}$ The majority of working children suffer from malnutrition. Indigenous people often suffer from malnutrition.

${ }^{54}$ Two possible extrajudicial executions.

${ }^{55}$ Overcrowding and mistreatment of prisoners.

${ }^{56}$ Although the report dates from 1994, State Department still quotes from an NGO report that suggests minors are more likely to be tortured and mistreated than adults. 
${ }^{57}$ The majority of children working have no access to education. Young girls working as domestic servants or nannies are denied access to education.

${ }^{58}$ Young girls working as servants or nannies are mistreated by their employers. Minors are frequently mistreated and tortured in police custody. There is no societal pattern of abuse of children. Underage conscripts are reported to be mistreated.

59 There are up to 26,000 children working as street vendors, shoe shiners, or prostitutes. Young girls work as servants or nannies (also see AE and CA). Many thousands of children under the age of 12 work in the informal sector as shoe shiner, selling newspapers and sundries, and cleaning car windows. Many children in rural areas as young as 10 work in the field (local NGO's do not see children harvesting as an abuse of child labour).

${ }^{60}$ Some minors were forced into obligatory military service before the age of 17 .

${ }^{61}$ Some landowners removed squatters violently.

${ }^{62}$ The majority of working children suffer from malnutrition. Indigenous people often suffer from malnutrition.

${ }^{63}$ There were two possible extrajudicial executions (and three political killings). Mistreatment in the army lead to several deaths.

${ }^{64}$ Conditions are extremely poor. Overcrowding, unsanitary conditions and mistreatment were very serious problems. During a visit by President Wasmosy he was shocked about the conditions in Panchito Lopez juvenile detention centre and ordered the installation of new roofing and sewage system. This work was finished within a month.

${ }^{65}$ The majority of children working have no access to education. Young girls working as domestic servants or nannies are denied access to education.

${ }^{66}$ Young girls working as servants or nannies are mistreated by their employers. There is no societal pattern of abuse of children. Underage conscripts are reported to be mistreated.

${ }^{67}$ There are up to 26,000 children working as street vendors or prostitutes. Young girls work as servants or nannies (also see AE and CA). Many thousands of children under the age of 12 work in the informal sector as shoe shiner, selling newspapers and sundries, and cleaning car windows. Many children in rural areas as young as 10 work in the field (local NGO's do not see children harvesting as an abuse of child labour).

${ }^{68}$ Some landowners removed squatters violently.

${ }^{69}$ The majority of working children suffer from malnutrition. Indigenous people often suffer from malnutrition.

${ }^{70}$ There were allegations of extrajudicial killings. At least two military recruits died (apparently following mistreatment and torture). It is difficult to quantify the extrajudicial executions. The State Department gives a couple of examples and then points to figures of the Attorney General's office and the Committee of Churches who 'compiled examples of numerous incidents of police abuse and extrajudicial killings'.

${ }^{71}$ Conditions are extremely poor. Overcrowding, unsanitary conditions and mistreatment were very serious problems. Another problem are the poor nutritional standards. 'Well-to-do' prisoners are far better off.

${ }_{72}$ CAT criticised Paraguay for mistreatment and torture of detainees. Several cases were reported.

73 The majority of children working have no access to education. Young girls working as domestic servants or nannies are denied access to education.

${ }^{74}$ Abuse of children is a problem. According to the Attorney General's office there are about 200 complaints per month about mistreatment and sexual abuse. Young girls working as servants or nannies are mistreated by their employers.

75 There are up to 26,000 children working as street vendors or prostitutes. Young girls work as servants or nannies (also see AE and CA). Many thousands of children under the age of 12 work in the informal sector as shoe shiner, selling newspapers and sundries, and cleaning car windows. Many children in rural areas as young as 10 work in the field (local NGO's do not see children harvesting as an abuse of child labour).

${ }^{76}$ Certain minors are forced into joining units, others are send by poor families to earn money.

${ }^{77}$ Some landowners removed squatters violently.

${ }^{78}$ The majority of working children suffer from malnutrition. (also see 'P'). Indigenous people often suffer from malnutrition.

${ }^{79}$ It is difficult to quantify the extrajudicial executions. The State Department points to figures of the Attorney General's office and the Committee of Churches who 'compiled examples of numerous incidents of police abuse and extrajudicial killings'. In previous years the State Department would point to 'possible instances' of extrajudicial killings. This points to an ' $E$ ' between brackets. In this report there is no such precision and no examples are given. This explains the brackets. The brackets in this report and previous brackets should thus be seen differently.

${ }^{80}$ Conditions are extremely poor. Overcrowding, unsanitary conditions and mistreatment were very serious problems. Another problem are the poor nutritional standards. 'Well-to-do' prisoners are far better off.

${ }^{81}$ Torture (primarily beatings) and brutal and degrading treatment of detainees continued. Several cases were reported.

${ }^{82}$ The majority of children working have no access to education. Young girls working as domestic servants or nannies are denied access to education.

${ }^{83}$ Child abuse is a problem. Many working children work in unsafe conditions. Some of the 11,500 young girls that work as servants or nannies are mistreated. The Attorney General's Office receives about 200 complaints of mistreatment or sexual abuse of minors.

${ }^{84}$ According to the United Nations Children's Fund one in three children (about 462,000) between the age of 7 and 17 work, often in unsafe labour conditions. Between 3,600 and 6,000 children work in the streets of Asuncion. About 11,500 young girls work as servants or nannies (also see AE and CA). Many children under the age of 12 work in the informal sector as shoe shiner, selling newspapers and sundries, and cleaning car windows. Many 
children in rural areas as young as 10 work in the field (local NGO's do not see children harvesting as an abuse of child labour).

${ }^{85}$ Of all the women who report being sexually exploited, $56.5 \%$ is younger than 16 .

${ }^{86}$ Certain minors are forced into joining units, others are send by poor families to earn money.

${ }^{87}$ Some landowners removed squatters violently.

${ }^{88}$ Many of the working children suffer from malnutrition. Indigenous people often suffer from malnutrition.

${ }^{89}$ The report once again is unclear. First, under the heading 'Political and Other Extrajudicial Killing', there were some extrajudicial killings. Two 'examples' are given. The report also mentions that some military recruits died 'as a result of beatings by superior officers'.

${ }^{90}$ Conditions are extremely poor. Overcrowding, unsanitary conditions and mistreatment were very serious problems. Another problem are the poor nutritional standards. 'Well-to-do' prisoners are far better off.

${ }^{91}$ Several cases were reported.

${ }^{92} 35,000$ children leave school every year. Though elementary school is compulsory through seventh grade (and in the future through ninth grade) the Government has no way of enforcing this in practice. In rural areas access to education for girls is markedly lower than in urban areas. The majority of children working have no access to education. Young girls working as domestic servants or nannies are denied access to education.

${ }^{93}$ Child abuse is a problem. Many working children work in unsafe conditions. Some of the 11,500 young girls that work as servants or nannies are mistreated. When a family does not have the means to raise a child it is common practice to send it to a colleague or relative. Here the child is expected to work in exchange for a room, board or access to education. Sometimes these children are abused. The Attorney General's Office receives about 200 complaints of mistreatment or sexual abuse of minors.

${ }^{94}$ According to the United Nations Children's Fund one in three children (about 462,000) between the age of 7 and 17 work, often in unsafe labour conditions. Between 3,600 and 6,000 children work in the streets of Asuncion. About 11,500 young girls work as servants or nannies (also see AE and CA). Many children under the age of 12 work in the informal sector as shoe shiner, selling newspapers and sundries, and cleaning car windows. Many children in rural areas as young as 10 work in the field (local NGO's do not see children harvesting as an abuse of child labour). . When a family does not have the means to raise a child it is common practice to send it to a colleague or relative. Here the child is expected to work in exchange for a room, board or access to education.

${ }^{95}$ Of all the women who report being sexually exploited, $58.5 \%$ is younger than 16 . There were allegations of trafficking of women and girls for prostitution to Brazil.

${ }^{96}$ Though legally all conscripts must be 18 when serving military service, in 1999 only $16 \%$ were older than 18 . Moreover 35\% were younger than 15 . It is alleged underage youths were forced into units. Others are send by poor families to earn money.

${ }^{97}$ Some landowners removed squatters violently. It was reported that in some cases the armed civilians were operating in conjunction with police personnel.

${ }_{98}^{98}$ Many of the working children suffer from malnutrition. Indigenous people often suffer from malnutrition.

${ }^{99}$ There were 13 extrajudicial executions and at least eight recruits died in questionable circumstances.

${ }^{100}$ Conditions are extremely poor. Overcrowding, unsanitary conditions and mistreatment were very serious problems. Another problem are the poor nutritional standards. 'Well-to-do' prisoners are far better off.

${ }^{101}$ Several cases of torture were reported. Moreover some persons involved in the attempted coup alleged they were tortured.

${ }^{102}$ Elementary school is compulsory through eighth grade (and in the future through ninth grade) the Government has no way of enforcing this in practice. The majority of children working have no access to education. Young girls working as domestic servants or nannies are denied access to education.

${ }^{103}$ Child abuse is a problem. Many working children work in unsafe conditions. Some of the 11,500 young girls that work as servants or nannies are mistreated. Sometimes these children are abused. The Attorney General's Office receives about 200 complaints of mistreatment or sexual abuse of minors. . When a family does not have the means to raise a child it is common practice to send it to a colleague or relative. Here the child is expected to work in exchange for a room, board or access to education.

${ }^{104}$ According to the United Nations Children's Fund one in three children (about 462,000) between the age of 7 and 17 work, often in unsafe labour conditions. Some 6,000 children work in the streets of Asuncion. About 11,500 young girls work as servants or nannies (also see AE and CA). Many children under the age of 12 work in the informal sector as shoe shiner, selling newspapers and sundries, and cleaning car windows. Many children in rural areas as young as 10 work in the field (local NGO's do not see children harvesting as an abuse of child labour).

${ }^{105}$ Trafficking in young girls for prostitution to Argentina was uncovered in August.

${ }^{106}$ Certain minors are forced into joining units, others are send by poor families to earn money.

${ }^{107}$ Violence erupted several times when police tried to remove squatters from lands they occupied. Armed civilians also violently tried to remove a group of indigenous people squatting by the side of a highway.

${ }^{108}$ Many of the working children suffer from malnutrition. Indigenous people often suffer from malnutrition.

${ }^{109}$ Over a dozen extrajudicial executions.

110 'Prison facilities are deficient'. Conditions are extremely poor. Overcrowding, unsanitary conditions and mistreatment were very serious problems. Another problem are the poor nutritional standards. 'Well-to-do' prisoners are far better off. In prisons for women there were cases of rape by male guards. An Amnesty International report on Panchito Lopez juvenile detention facility in Asuncion concluded there was overcrowding, the cells were 'overheated, with few toilet or washing facilities'. Inmates were kept in isolation cells and they 
suffered retaliation for talking to A.I. Five children were tortured during the year. Some children were denied food, drink, or access to toilets, for several days.

${ }^{111}$ It is difficult to ascertain how many cases of torture there were in 2001. The report speaks of an NGO reporting several cases of torture and names a couple of cases (also see 'P'). A number of cases from 2000 are further clarified. Especially in the aftermath of the failed coup it becomes more clear a number of people were tortured.

${ }^{112}$ The majority of children working have no access to education. Young girls working as domestic servants or nannies are denied access to education.

${ }^{113}$ Child abuse and neglect is a problem. Many working children work in unsafe conditions. Some of the 11,500 young girls that work as servants or nannies are mistreated. Sometimes these children are abused. The Attorney General's Office receives about 200 complaints of mistreatment or sexual abuse of minors. The Childhood and Adolescence Act was enacted in December. This sets forth 'human rights provisions and establishes a mechanism for reviewing allegations of abuse'.

${ }^{114}$ According to the United Nations Children's Fund one in three children (about 462,000) between the age of 7 and 17 work, often in unsafe labour conditions. Between 3,600 and 6,000 children work in the streets of Asuncion. About 11,500 young girls work as servants or nannies (also see AE and CA). Many children under the age of 12 work in the informal sector as shoe shiner, selling newspapers and sundries, and cleaning car windows. Many children in rural areas as young as 10 work in the field (local NGO's do not see children harvesting as an abuse of child labour).

${ }^{115}$ A study identified 619 child victims of sexual exploitation, 33\% of them were under the age of 16 . Trafficking in girls for sexual exploitation was a problem.

${ }^{116}$ There were cases of conscription of minors.

${ }^{117}$ Many of the working children suffer from malnutrition. Indigenous people often suffer from malnutrition. 


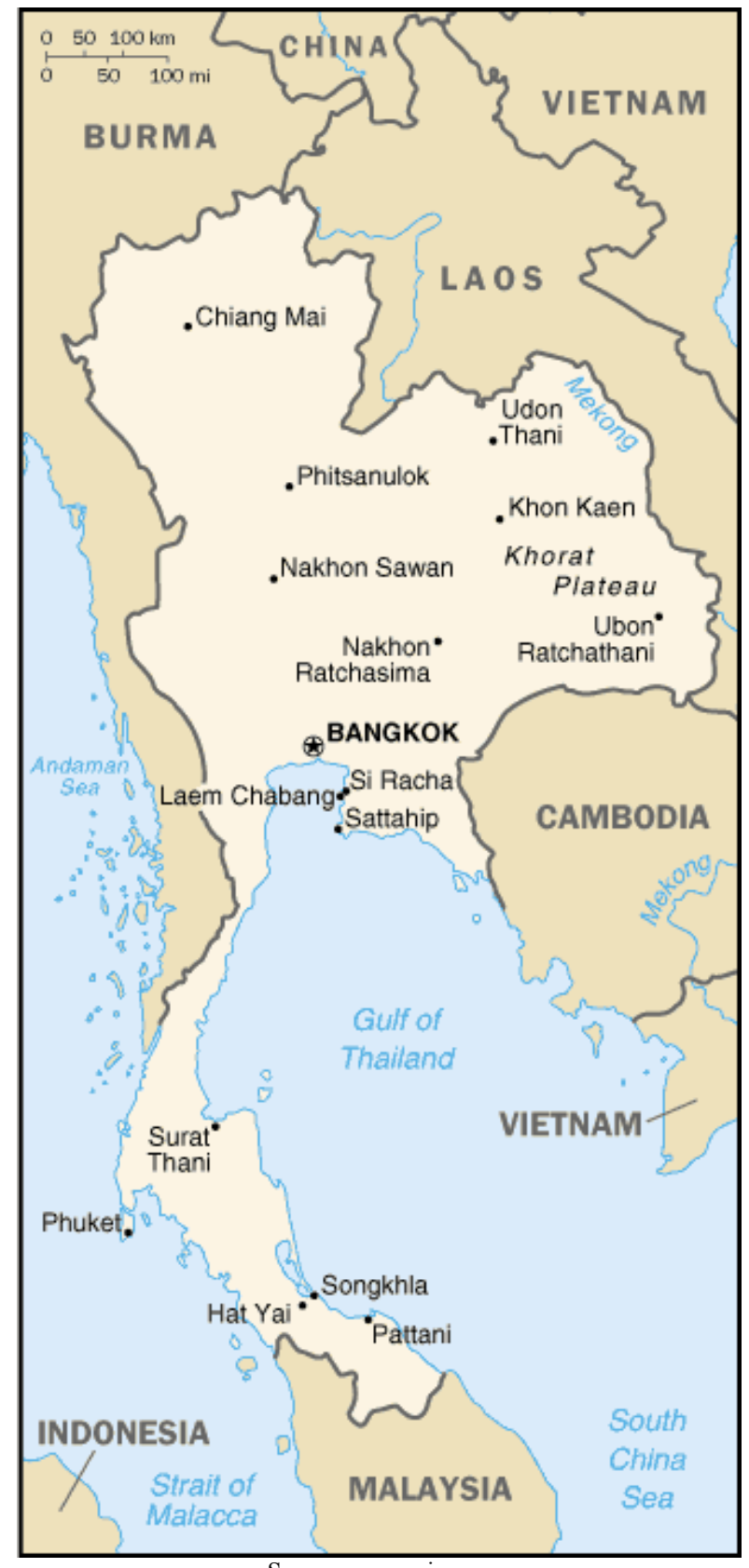

Source: www.cia.gov

THAILAND*

(Population: 64,265,276)

\begin{tabular}{|c|c|c|c|c|}
\hline & 1989 & 1990 & 1991 & 1992 \\
\hline $\begin{array}{c}\text { Political } \\
\text { Terrorscale }\end{array}$ & $2 / 2$ & $3 / 2$ & $2 / 2$ & $4 / 3$ \\
\hline \multicolumn{5}{|l|}{ Conflict Level } \\
\hline $\begin{array}{l}\text { Freedom } \\
\text { House }\end{array}$ & $2 / 3 / F$ & $2 / 3 / F$ & $6 / 4 / \mathrm{PF}$ & $3 / 4 / \mathrm{PF}$ \\
\hline $\begin{array}{c}\text { U.S. State } \\
\text { Department }\end{array}$ & $\begin{array}{c}(\mathrm{e})^{2}, \mathrm{t}^{3}, \mathrm{CA}, \mathrm{CL}^{4}, \\
\mathrm{CP}^{5}, \mathrm{FE}^{6}\end{array}$ & $\begin{array}{c}\mathrm{e}^{7}, \mathrm{p}^{8}, \mathrm{t}^{9}, \mathrm{CA}, \mathrm{CL}^{10}, \\
\mathrm{CP} / \mathrm{FL}^{11}\end{array}$ & $\begin{array}{l}\mathrm{E}^{12}, \mathrm{p}^{13},(\mathrm{t})^{14}, \mathrm{CA}, \\
\mathrm{CL}^{15}, \mathrm{CP} / \mathrm{FL}^{16}\end{array}$ & $\begin{array}{l}\mathrm{E}^{17}, \mathrm{p}^{18},(\mathrm{t})^{19}, \mathrm{CA}, \\
\mathrm{CL}^{20}, \mathrm{CP}^{21}\end{array}$ \\
\hline
\end{tabular}




\begin{tabular}{|c|c|c|c|c|}
\hline & 1993 & 1994 & 1995 & 1996 \\
\hline $\begin{array}{c}\text { Political } \\
\text { Terrorscale }\end{array}$ & $2 / 3$ & $3 / 3$ & $2 / 2$ & $2 / 3$ \\
\hline \multicolumn{5}{|l|}{ Conflict Level } \\
\hline $\begin{array}{l}\text { Freedom } \\
\text { House }\end{array}$ & $3 / 5 / \mathrm{PF}$ & $3 / 5 / \mathrm{PF}$ & $3 / 4 / \mathrm{PF}$ & $3 / 3 / \mathrm{PF}$ \\
\hline $\begin{array}{l}\text { U.S. State } \\
\text { Department }\end{array}$ & $\begin{array}{l}E^{22}, p^{23},(t), C^{24} \\
C L / F^{25}, C P / T P^{26}\end{array}$ & $\begin{array}{l}\mathrm{E}^{27}, \mathrm{p}^{28}, \mathrm{t}, \mathrm{CA}^{29} \\
\mathrm{CL} / \mathrm{FL}^{30}, \mathrm{CP} / \mathrm{TP}^{31}\end{array}$ & $\begin{array}{c}\mathrm{E}^{32}, \mathrm{p}^{33}, \mathrm{t},(\mathrm{CA})^{34} \\
\mathrm{CL}^{35}, \mathrm{CP} / \mathrm{TP}^{36}\end{array}$ & $\begin{array}{c}(\mathrm{E})^{37}, \mathrm{p}^{38}, \mathrm{t},(\mathrm{CA})^{39}, \\
\mathrm{CL}^{40}, \mathrm{CP}^{41}\end{array}$ \\
\hline
\end{tabular}

* Only the period 1989-1996 has been investigated because afterwards no change has been observed.

\section{Working conditions:}

1989: Safety and health standards in medium and large-sized factories are often maintained. However in the large informal sector health and safety standards are often not upheld or understood. The increase in the national force of labour inspectors will remain inadequate in pursuing all potential violations. Inspection and enforcement practices are often critisized by observers.

1990: Safety and health standards in medium and large-sized factories are often maintained. However in the large informal sector health and safety standards are often not upheld or understood.

1991: Safety and health standards in medium and large-sized factories are often maintained. However in the large informal sector health and safety standards are often not upheld or understood.

1992: Safety and health standards in medium and large-sized factories are often maintained. However in the large informal sector health and safety standards are often not upheld or understood.

1993: Safety and health standards in medium and large-sized factories are often maintained although lax enforcement is still too common. The large informal sector is even less inspected. Employers are able to ignore regulations simply because workers do not have access to safety and health standards and can thus not report any violations.

1994: There are reports of sweatshops in the informal sector that physically restrain workers from leaving the premises. With the increasing influx of Burmese refugees the opportunities for such abuse increase. Safety and health standards in medium and large-sized factories are often maintained, but lax enforcement of safety standards is common. In the large informal sector, 'the health and safety environment is substandard'. Employers are able to ignore regulations simply because non unionised workers do not understand safety and health standards and can thus not report any violations. 1994 was designated as "Year of workplace safety".

1995: There are reports of sweatshops in the informal sector that physically restrain workers from leaving the premises. With the increasing influx of Burmese refugees the opportunities for such abuse increase. Safety and health standards in medium and large-sized factories are often maintained, but lax enforcement of safety standards is common. In the large informal sector, 'the health and safety environment is substandard'. Employers are able to ignore regulations simply because non unionised workers do not understand safety and health standards and can thus not report any violations. 
1996: There are reports of sweatshops in the informal sector that physically restrain workers from leaving the premises. With the increasing influx of refugees from Burma, Cambodia and Laos the opportunities for such abuse increase. There are reports of sweatshops in the informal sector that physically restrain workers from leaving the premises. With the increasing influx of Burmese refugees the opportunities for such abuse increase. Safety and health standards in medium and large-sized factories are often maintained, but lax enforcement of safety standards is common. In the large informal sector, 'the health and safety environment is substandard'. Employers are able to ignore regulations simply because non unionised workers do not understand safety and health standards and can thus not report any violations.

\section{Brief historical/political overview:}

1989: Communist insurgent and Muslim separist groups use terrorism to advance their aims. Although the Government did much to curb the violence, sporadic violence still occurs in the south.

1991: On February 23 a military coup deposes of the prime minister, the 1978 constitution is abrogated and the bicameral system abolished. The military leaders form a "National Peacekeeping Council" and name a civilian Prime Minister who chooses a cabinet comosed mainly of civilian technocrats. A new constitution is drafted by a council appointed legislative assembly and promulgated on December 9. A new electoral law is also approved and parliamentary elections are due for March 22 1992. Critics say the new constitution extends the influence of the military beyond the election.

1992: Following the March elections lead to a pro military coalition. Unable to agree on a Prime Minister, the parties turn to the mastermind of the coup, General Suchinda Khaprayun. Although the General is not an elected M.P. and had previously stated he would not become Prime Minister. The naming of the General lead to Pro-democracy demonstrations in May which are violently suppressed by the military. The demonstrations lead to 52 deaths with an additionnal 200 missing. In an unusual step the King called on both sides to resolve their differences. On May 24 the General resigns, and former caretaker Prime Minister Anan takes up the role of caretaker Prime Minister once again. Following the May demonstrations, the military loose some of its powers and the Council's members are moved into inctive positions, crowd control is moved from the military to the police. In September free and fair elections are held. Chuan is prime minister and heads a five-party coalition. Military supports democratic government. However the military still is very influential especially outside the capital.

1993: The government is more committed to human rights. Military supports democratic government. However the military still is very influential especially outside the capital. In September violence erupts in Southern Thailand. Muslims are blamed for the violence.

1995: In May the Parliament is dissolved as it was clear that the Government of Prime Minister Chuan Leekpai would not survive a no-confidence vote. In July, after democratic elections the Chuan administration was replaced by 'a coalition government headed by Prime Minister Banharn Silpa-Archa'. The courts rarely convict police officers of human rights abuses. This results in impunity, which is seen as the single most important factor witholding change in police behabior.

1996: The coalition government of Banharn Silpa-Archa was dissolved after a no confidence vote. On November 17 elections were held and won by General Chavalit Yongchaiudh's New Aspiration Party. The party formed together with five other parties a coalition government. The elctions were free, but fraudulent.

\footnotetext{
${ }^{1}$ Following a directive by Secretary of State Warren Christopher some changes in reporting were made as of the 1993 report. The changes include a stronger emphasis on prison conditions and a new section on "discrimination based on race, sex, religion, disability, language or social status. This new section also includes a paragraph on discrimination against children.

${ }^{2}$ In the fight against muslim separatists "security forces sometimes shoot first and ask questions later." This resulted in at least 4 deaths in questionable circumstances.
} 
3 At least one person was tortured. In the period between 1983 and 1988 police brutality often during interrorgation lead to 132 injuries and 27 deaths. Police is often accused of beatings of prisoners and detainees. These beatings can in some cases constitute torture, however it is unclear from the report whether they do.

${ }^{4}$ Child labour was a serious problem. Standards on the prohibition of child labour in Thailand are very low. There is a great amount of evidence suggesting that children between the age of 12 and 15 were employed in dangerous, unhealthful, or otherwise harmful circumstances. This is against Thai law which allows for children in that age group to do light work. However inspections and ressources to enforce the law are inadequate.

${ }^{5}$ Official estimates state there are 30,000 minors working as prostitutes.

${ }^{6}$ Refugees living along the border controlled by the forces of Democratic Kampuchea were frequently forced to move, exposing them to shelling and landmines.

${ }^{7}$ In their conflict with muslim separatists security forces sometins kill civilians, claiming this is done mistakingly.

${ }^{8}$ Conditions at Soi Suan Phlu Imigration Detention Center constitute cruel and unusual punishment.

${ }^{9}$ At least two persons were tortured. Police is often accused of beatings of prisoners and detainees. These beatings can in some cases constitute torture, however it is unclear from the report whether thay do.

${ }^{10}$ Child labour was a serious problem. Thai government has changed the law raising the minimum age from 12 to 13. Between 13 and 15 children are permitted to do light work. However there is a great amount of evidence suggesting that children between the age of 13 and 15 were employed in dangerous, unhealthful, or otherwise harmful circumstances. Inspections and ressources to enforce the law are inadequate. The Department of Labor has vowed to triple the amount of inspectors. Thai government has vowed to raise compulsory education from 6 to 9 years.

${ }^{11}$ There are some well documented cases of children being forced into prostitution and kept as near captives in brothels.

${ }^{12}$ In areas outside the capital, particularly in areas with high crime rates police occasionally summarily execute suspected criminals. A "shoot to kill" policy has been reported to have been imposed to crack down on car thefts. This reportedly lead to 20 deaths. A campaign to surpress "mafia-style" godfathers lead to one death. Poorly disciplined policemen engage in criminal activity, "hiring themselves out as contract killers". In 1991 eight policemen were charged with murder in five cases involving seven victims. At least three of these cases involve summary execution. There were credible reports of posthumous shooting by the police of prisoners to cover up "deaths caused by beatings and physical abuse." Victims were then reported to have committed suicide.

${ }^{13}$ Conditions at Soi Suan Phlu Imigration Detention Center constitute cruel and unusual punishment. There is severe overcrowding, lach of medical care, no possibility of exercise and there are many diseases among detainees.

${ }^{14}$ Police is often accused of beatings of prisoners and detainees. These beatings can in some cases constitute torture, however it is unclear from the report whether they do.

${ }^{15}$ Child labour is a very serious problem. Between 13 and 15 children are permitted to do light work. However there is a great amount of evidence suggesting that children between the age of 13 and 15 were employed in dangerous, unhealthful, or otherwise harmful circumstances. Inspections and ressources to enforce the law are inadequate. The Department of Labor has doubled the amount of inspectors. Thai government has vowed to raise compulsory education from 6 to 9 years. In 1991 the ILO issued a "special paragraph" chastising the Thai government for its lack of effective implementation of laws prohibiting child labour. This is the most severe rebuke the ILO can hand out to member states.

${ }_{17}^{16}$ In one raid police found 31 boys between 13 and 17 to be detained and forced to work 16 hours a day.

${ }^{17}$ In the Northeastern region alone 30 people were summarily executed in the first six months of 1992. At least 50 canvassers were killed by hired gunmen during both elections.

${ }^{18}$ Conditions at Soi Suan Phlu Imigration Detention Center constitute cruel and unusual punishment. There is severe overcrowding, lach of medical care, no possibility of exercise and there are many diseases among detainees.

${ }^{19}$ Police is often accused of beatings of prisoners and detainees. These beatings can in some cases constitute torture, however it is unclear from the report whether they do.

${ }^{20}$ Child labour is a very serious problem. Between 13 and 15 children are permitted to do light work. However there is a great amount of evidence suggesting that children between the age of 13 and 15 were employed in dangerous, unhealthful, or otherwise harmful circumstances. Inspections and ressources to enforce the law are inadequate. The Department of Labor has doubled the amount of inspectors. Thai government has vowed to raise compulsory education from 6 to 9 years. Inspections rose from 100 per month to 1000 per month, prosecutions rose and 1992 saw the beginning of a campaign against child labour.

${ }^{21}$ According to one group there are approximately 800,000 prostitutes under the age of 16 .

${ }^{22}$ It is difficult for NGO's to get exact figures. Summary executions are known to happen and one count of only 34 districts recorded 60 deaths upon arrest or in police custody in 1992. It is not known how many of these deaths could have been avoided. Figures for 1993 were unavailable (see 1994).

23 Prison conditions are not life threatening, but there is a problem with abuse by guards. Conditions in Suan Phlu Immigration Detention Facility constitute 'cruel and unusual punishment', due to extreme overcrowding and lack of medical care.

${ }^{24}$ There is a problem of domestic abuse which also includes child abuse.Abuse in prostitution and labour is widespread. 
${ }^{25}$ The problem is widespread. Government estimates indicate there are up to 100,000 children between the age of 13 and 15 working. The real figure is probably much higher. Increased inspections found a great number of children under 13 working. Many in 'dangerous, unhealthful, or otherwise harmful circumstances'.

${ }^{26}$ The problem is widespread.

${ }^{27}$ It is difficult for NGO's to get exact figures. Summary executions are known to happen and one count recorded 31 deaths upon arrest and 23 in police custody in 1993. It is not known how many of these deaths could have been avoided. Figures for 1994 were unavailable (see 1995).

${ }^{28}$ Prison conditions are not life threatening, however there is a problem with abuse by prison guards, solitary confinement and the use of heavy leg irons on difficult prisoners. Medical care is inadequate. Conditions at Suan Phlu Immigration Detention Center are extremely poor, there is severe overcrowding, lack of medical care, inability yo exercise, and physical abuse (including sexual abuse).

${ }^{29}$ Abuse in prostitution and labour is widespread. There is also a problem in domestic (child) abuse.

${ }^{30}$ The problem is widespread. Government estimates indicate there are up to 100,000 children between the age of 13 and 15 working. The real figure is probably much higher. Inspections increased, but remained inadequate. In order to deal with the problem the government made education cumpolsory from 6 to 9 years.

${ }^{31}$ The problem is widespread. A special task force was created and new laws provide tougher sentences. An additionnal problem directly related to child prostitution is the AIDS epedemic. 'Children are particular victims of the AIDS epedemic'.

${ }^{32}$ According to the police information center there were 22 extrajudicial executions and 24 suspects who died during arrest. The Legal Information Center listed a total of 359 deaths in police or Department of Corrections custody in 1994. It is not known how many of these deaths could have been avoided. Figures for 1995 were unavailable. There was one political killing.

${ }^{33}$ Conditions are spartan. There is a problem with abuse by prison guards, solitary confinement and the use of heavy leg irons on difficult prisoners. Medical care is inadequate. Conditions at Suan Phlu Immigration Detention Center are extremely poor, there is severe overcrowding, lack of medical care, inability to exercise, and physical abuse (including sexual abuse).

${ }^{34}$ It is unclear whether the problem is widespread. New laws provide harsher punishment, but the police is reluctant to pursue abuse cases.

${ }^{35}$ It is estimated 850,000 children work mostly on family farms. Between 240,000 and 410,000 children between the ages of 6 to 14 (2 to $4 \%$ of that group) 'are estimated to be in urban employment at particular risk of labor abuse'. There are an increased number of inspectors, but enforcement of child lanour laws is not 'rigorous'.

${ }^{36}$ The problem is widespread. New laws provide tougher sentences. About half of all prostitutes began working before they were 18. An additionnal problem directly related to child prostitution is the AIDS epedemic. 'Children are particular victims of the AIDS epedemic'.

${ }^{37}$ Where in other years it was clearly indicated that there were a number of extrajudicial executions the 1996 report states some police officers 'summarily executed criminal suspects'. All of the figures that follow are the number of deaths that have occurred upon arrest (a number of these deaths can be explained through self defence) and in custody (by police or in prison). Those figures are the following. The police information center claims 23 people were killed during attempted arrest in 1995, and 16 during the first half of 1996. The Attorney General's office reported 324 suspects that died while in 'custody of government officials' in 1995, during the first half of 1996 the number was 205. According to the police 98 died after 'initial detention' in 1995 and the first half of 1996 (the police claim 63 of those were suicides). This does not seem correct as regional authorities documented up to 140 deaths in custody. There were two political killings. In any case there is an increase in the number extrajudicial killings.

${ }^{38}$ Conditions are spartan. There is a problem with abuse by prison guards, solitary confinement and the use of heavy leg irons on difficult prisoners. Medical care is inadequate. Prisoners caught attempting to escape are often beaten, sometimes beaten to death.Conditions at Suan Phlu Immigration Detention Center are poor. An increased budget improved standards somewhat. However there is severe overcrowding, lack of medical care, and inability to exercise.

${ }^{39}$ It is unclear whether the problem is widespread. New laws provide harsher punishment, but the police is reluctant to pursue abuse cases.

${ }^{40}$ It is estimated 850,000 children work mostly on family farms. Between 240,000 and 410,000 children between the ages of 6 to 14 ( 2 to $4 \%$ of that group) 'are estimated to be in urban employment at particular risk of labor abuse'. There are an increased number of inspectors, but enforcement of child lanour laws is not 'rigorous'.

${ }^{41}$ There are probably from 20,000 to 40,000 child prostitutes. 


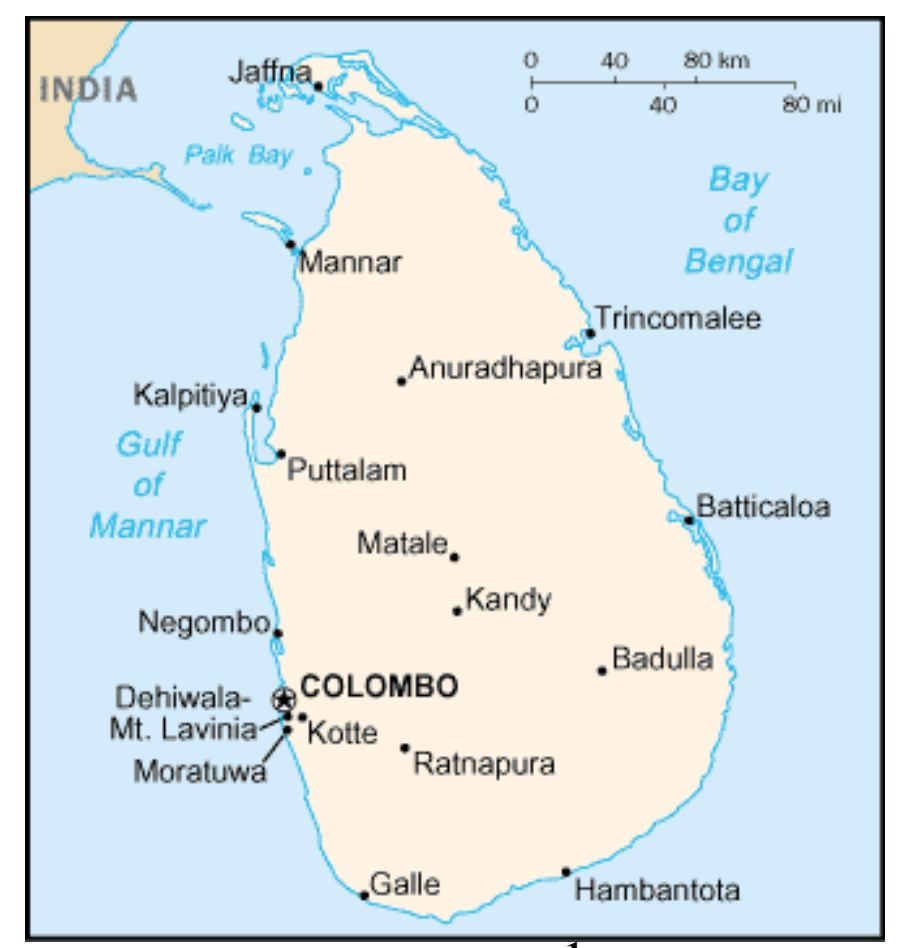

Sri Lanka ${ }^{1}$

(Population: 19,742,439)

\begin{tabular}{|c|c|c|c|c|}
\hline $\mathbf{1 9 8 9}$ & 1990 & 1991 & 1992 \\
\hline $\begin{array}{c}\text { Political } \\
\text { Terrorscale }\end{array}$ & $5 / 5$ & $5 / 5$ & $5 / 4$ & $5 / 4$ \\
\hline Conflict Level & $\begin{array}{c}\text { High intensity } \\
\text { conflict }^{2}\end{array}$ & $\begin{array}{c}\text { High intensity } \\
\text { conflict }\end{array}$ & $\begin{array}{c}\text { High intensity } \\
\text { conflict }\end{array}$ & $\begin{array}{c}\text { High intensity } \\
\text { conflict }\end{array}$ \\
\hline $\begin{array}{c}\text { Freedom } \\
\text { House }\end{array}$ & $4 / 5 / \mathrm{PF}$ & $4 / 5 / \mathrm{PF}$ & $4 / 5 / \mathrm{PF}$ & $4 / 5 / \mathrm{PF}$ \\
\hline $\begin{array}{c}\text { U.S. State } \\
\text { Department }\end{array}$ & $\mathrm{E}^{6}, \mathrm{~T}, \mathrm{CL}^{7}$ & $\mathrm{E}^{8}, \mathrm{p}^{9}, \mathrm{~T}, \mathrm{CL}^{10}$ & $\mathrm{E}^{11}, \mathrm{~T}^{12}, \mathrm{AE}^{13}, \mathrm{CL}^{14},\left(\mathrm{C}^{16}\right.$ & $\mathrm{E}^{17}, \mathrm{~T}^{18}, \mathrm{AE}^{19}, \mathrm{CL}^{20}$, \\
$\mathrm{CP}^{21}$
\end{tabular}

\begin{tabular}{|c|c|c|c|c|}
\hline & 1993 & 1994 & 1995 & 1996 \\
\hline $\begin{array}{c}\text { Political } \\
\text { Terrorscale }\end{array}$ & $5 / 4$ & $4 / 3$ & $4 / 5$ & $5 / 4$ \\
\hline Conflict Level & $\begin{array}{l}\text { High-intensity } \\
\text { conflict }^{22}\end{array}$ & $\begin{array}{l}\text { Low-intensity } \\
\text { conflict }^{23}\end{array}$ & $\begin{array}{l}\text { High intensity } \\
\text { conflict }\end{array}$ & $\begin{array}{l}\text { High intensity } \\
\text { conflict }\end{array}$ \\
\hline $\begin{array}{l}\text { Freedom } \\
\text { House }\end{array}$ & $4 / 5 / \mathrm{PF}$ & $4 / 5 / \mathrm{PF}$ & $4 / 5 / \mathrm{PF}$ & $3 / 5 / \mathrm{PF}$ \\
\hline $\begin{array}{c}\text { U.S. State } \\
\text { Department }\end{array}$ & $\begin{array}{l}\mathrm{E}^{24}, \mathrm{~T}^{25}, \mathrm{AE}^{26}, \mathrm{CA}^{27}, \\
\quad \mathrm{CL} / \mathrm{FL}^{28}, \mathrm{CP}^{29}\end{array}$ & $\begin{array}{c}\mathrm{E}^{30} / \mathrm{e}^{31}, \mathrm{p}^{32}, \mathrm{~T}^{33} \\
\mathrm{AE}^{34}, \mathrm{CA}^{35}, \mathrm{CL} / \mathrm{FL}^{36} \\
\mathrm{CP}^{37}\end{array}$ & $\begin{array}{l}\mathrm{E}^{38}, \mathrm{p} / \mathrm{P}^{39}, \mathrm{~T}^{40}, \mathrm{AE}^{41} \\
\mathrm{CA}^{42}, \mathrm{CL} / \mathrm{FL}^{43}, \mathrm{CP}^{44}\end{array}$ & $\begin{array}{l}\mathrm{E}^{45}, \mathrm{p} / \mathrm{P}^{46}, \mathrm{~T}^{47}, \mathrm{AE}^{48} \\
\mathrm{CA}^{49}, \mathrm{CL} / \mathrm{FL}^{50}, \mathrm{CP}^{51}\end{array}$ \\
\hline
\end{tabular}




\begin{tabular}{|c|c|c|c|c|}
\hline & 1997 & 1998 & 1999 & 2000 \\
\hline $\begin{array}{c}\text { Political } \\
\text { Terrorscale }\end{array}$ & 4 & 4 & & 5 \\
\hline Conflict Level & $\begin{array}{l}\text { high intensity } \\
\text { conflict }^{52}\end{array}$ & $\begin{array}{l}\text { high intensity } \\
\text { conflict }^{53}\end{array}$ & $\begin{array}{l}\text { high intensity } \\
\text { conflict }^{54}\end{array}$ & $\begin{array}{l}\text { high intensity } \\
\text { conflict }^{55}\end{array}$ \\
\hline $\begin{array}{c}\text { Freedom } \\
\text { House }\end{array}$ & $3 / 4 / \mathrm{PF}$ & $3 / 4 / \mathrm{PF}$ & $3 / 4 / \mathrm{PF}$ & $3 / 4 / \mathrm{PF}$ \\
\hline $\begin{array}{c}\text { U.S. State } \\
\text { Department }\end{array}$ & $\begin{array}{c}\mathrm{E}^{56}, \mathrm{p} / \mathrm{P}^{57}, \mathrm{~T}^{58}, \\
\mathrm{AE}^{59}, \mathrm{CA}^{60}, \mathrm{CL} / \mathrm{FL}^{61} \\
\mathrm{CP}^{62}\end{array}$ & $\begin{array}{c}\mathrm{E}^{63}{ }^{63} \mathrm{p} / \mathrm{P}^{64}, \mathrm{~T}^{65}, \mathrm{AE}^{66}, \\
\mathrm{CA}^{67}, \mathrm{CL}^{6} / \mathrm{FL}^{68}, \mathrm{CP}^{69}, \\
\mathrm{FE}^{70}\end{array}$ & $\begin{array}{c}\mathrm{E}^{71}, \mathrm{p} / \mathrm{P}^{72}, \mathrm{~T}^{73}, \mathrm{AE}^{74}, \\
\mathrm{CA}^{75}, \mathrm{CL}^{7} / \mathrm{FL}^{76}, \mathrm{CP}^{77}, \\
\mathrm{TL} / \mathrm{TP}^{78},(\mathrm{IF})^{79}\end{array}$ & $\begin{array}{c}\mathrm{E}^{80}, \mathrm{p} / \mathrm{P}^{81}, \mathrm{~T}^{82}, \mathrm{AE}^{83}, \\
\mathrm{CA}^{84}, \mathrm{CL}^{8} / \mathrm{FL}^{85}, \mathrm{CP}^{86}, \\
\mathrm{TL} / \mathrm{TP}^{87}, \mathrm{IF}^{88}\end{array}$ \\
\hline
\end{tabular}

\begin{tabular}{|c|c|c|}
\hline & 2001 & 2002 \\
\hline \multicolumn{3}{|l|}{$\begin{array}{c}\text { Political } \\
\text { Terrorscale }\end{array}$} \\
\hline Conflict Level & $\begin{array}{l}\text { High intensity } \\
\text { conflict }^{89}\end{array}$ & $\begin{array}{l}\text { Violent political } \\
\text { conflict }^{90}\end{array}$ \\
\hline $\begin{array}{l}\text { Freedom } \\
\text { House }\end{array}$ & $3 / 4 / \mathrm{PF}$ & $3 / 4 / \mathrm{PF}$ \\
\hline $\begin{array}{c}\text { U.S. State } \\
\text { Department }\end{array}$ & 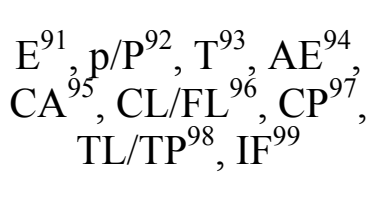 & $\begin{array}{l}(\mathrm{e})^{100}, \mathrm{p}^{101}, \mathrm{~T}^{102}, \\
\mathrm{AE}^{103}, \mathrm{CA}^{104}, \\
\mathrm{CL} / \mathrm{FL}^{105}, \mathrm{CP}^{106}, \\
\mathrm{TL} / \mathrm{TP}^{107}, \mathrm{IF}^{108}\end{array}$ \\
\hline
\end{tabular}

\section{Working conditions:}

1989: Union leaders allege that government enforcement of health and safety standards is poor.

1990: Government enforcement of health and safety standards is poor.

1991: Government enforcement of health and safety standards is poor.

1992: Most workers are not properly instructed on the risks they are taking.

1993: The graphite industry records the highest number of health hazards. In tea factories, asthma and chronic bronchitis are common. Workers have the statutory right to remove themselves from situations that endanger their health, but much of the work force is either unaware of, or indifferent to, the risks involved in their work.

1994: Workers have the statutory right to remove themselves from situations that endanger their health, but much of the work force is either unaware of, or indifferent to, the risks involved in their work.

1995: Workers have the statutory right to remove themselves from situations that endanger their health, but much of the work force is either unaware of, or indifferent to, the risks involved in their work. 
1996: Workers have the statutory right to remove themselves from situations that endanger their health, but much of the work force is either unaware of, or indifferent to, health risks, and fear that they will lose their jobs if they remove themselves.

1997: Pro-Government militant groups use forced conscription. Tamil youth are forced to join these groups under threats to themselves and their families. There are reports that some members of the police Special Task Force operating in the Batticaloa area force local villagers to work without compensation in clearing jungle and in other manual labor in and near STF camps. Industrial Workers have the statutory right to remove themselves from situations that endanger their health, but much of the work force is either unaware of, or indifferent to, health risks, and fear that they will lose their jobs if they remove themselves.

1998: Pro-Government militant groups use forced conscription. Tamil youth are forced to join these groups under threats to themselves and their families. There are reports that some members of the police Special Task Force operating in the Batticaloa area force local villagers to work without compensation in clearing jungle and in other manual labor in and near STF camps. Industrial Workers have the statutory right to remove themselves from situations that endanger their health, but much of the work force is either unaware of, or indifferent to, health risks, and fear that they will lose their jobs if they remove themselves.

1999: Progovernment Tamil groups use forced conscription. There are credible reports that Tamil youth in the East in particular have been forced to join these groups under threats to themselves and their families. There are reports that some members of the police Special Task Force operating in the Batticaloa area force local villagers to work without compensation in clearing jungle and in other manual labor in and near STF camps. Industrial Workers have the statutory right to remove themselves from situations that endanger their health, but much of the work force is either unaware of, or indifferent to, health risks, and fear that they will lose their jobs if they remove themselves. There are credible reports of women being trafficked into the country for prostitution and forced labor.

2000: Progovernment Tamil groups use forced conscription. There are credible reports that Tamil youth in the East in particular have been forced to join these groups under threats to themselves and their families. There are reports that some members of the police Special Task Force operating in the Batticaloa area force local villagers to work without compensation in clearing jungle and in other manual labor in and near STF camps. There are credible reports of women being trafficked into the country for prostitution and forced labor. Industrial Workers have the statutory right to remove themselves from situations that endanger their health, but much of the work force is either unaware of, or indifferent to, health risks, and fear that they will lose their jobs if they remove themselves. Health and safety regulations do not meet international standards.

2001: There are credible reports of women being trafficked into the country for prostitution and forced labor. Citizens were trafficked to the United Kingdom for labor exploitation. Industrial Workers have the statutory right to remove themselves from situations that endanger their health, but much of the work force is either unaware of, or indifferent to, health risks, and fear that they will lose their jobs if they remove themselves. Health and safety regulations do not meet international standards.

2002: There are credible reports of women being trafficked into the country for prostitution and forced labor. Industrial Workers have the statutory right to remove themselves from situations that endanger their health, but much of the work force is either unaware of, or indifferent to, health risks, and fear that they will lose their jobs if they remove themselves. Health and safety regulations do not meet international standards.

\section{Brief historical/political overview}

1989: Tensions in the eighties between Sri Lanka's majority Sinhalese and minority Tamil populations lead to armed conflict between government forces and Tamil separatists. A peace accord between the governments of India and Sri Lanka was signed. However radicals from both major ethnic groups refused to accept the Accord. In the Sinhalese-majority south, government security forces were pitted against the revolutionary Janatha Vmukthi Peramuna 
(JVP) attempting to overthrow the Government by terrorist methods. In the Tamil-mjority northeast, the Liberation Tigers of Tamil Eelam (LTTE) waged guerilla war against the Indian Peace-Keeping Force (IPKF), introduced under the Accord, and India's Tamil militant allies. The attacks by the JVP did not stop even after having tried to bring the JVP into political life and legalise the organisation. Thus in 1989 the Government cracked down on the JVP, arrested many suspected members and killed much of the JVP's top leadership. In September a Peace Accord was signed between the LTTE and Indian Forces and Tamil allies. In the same months India and Sri Lanka agreed on the withdrawal of Indian soldiers. The withdrawal started during the year and will be complete by March 31, 1990. In one incident in December withdrawing IPKF soldiers clashed with LTTE rebels. The result was 100 combatants dead and 50 civilians dead. A new Parliament was voted in February. The elections were marred by the killing of hundreds of voters and 14 parliamentary candidates. However the elections were considered largely free and fair. The Prevention of Terrorism Act was in effect throughout the year. There was a rise of anti-JVP vigilante groups in the south. Observers largely agree these groups are manned partly by security personnel operating with the knowledge of the Government. IPKF troops used torture. In the South the JVP used intimidation to recruit unwilling members and to force participation in demonstrations and other activities liable to subject individuals to criminal prosecution. They did this in universities and secondary schools. This resulted in much campus unrest and closure of most schools for the rest of the year. India's Tamil allies forcibly recruit young men to provide manpower for the defense of Tamil-majority areas. A great number of people disappeared.

1990: The IPKF withdrew by March 31. JVP cadres were unable to regroup sufficiantly after much of their leadership was captured or killed. LTTE seized control of the Jaffna Peninsula, while continuing negotiations. The Government ordered the army to take a non-confrontational stand. On June 11 LTTE broke of negotiations and attacked a number of police stations in the east. The human rights situations, which had ameliorated during peace negotiations, seriously deteriorated in the northeast after talks were broken off. In the south the situation ameliorated due to the elimination of the JVP leadership. However vigilante groups continued to operate. The PTA and Emergency Regulations remained in effect. However some provisions were rescinded. A great number of people disappeared.

1991: The conflict with LTTE continued. JVP terrorism ended. Life in the South was largely normal. LTTE operations were largely confined to the north and east. However two bombs in Colombo destroyed the Ministry of Defence and left many civilians dead. Number of incidents was reduced. 710 civilians died in 1991. PTA and ER remained in force,but were partly suspended (except in the northeast) to permit unhindered elections. A great number of people disappeared. Though less than in the previous five years. The Government publicly and privately declared the war in the east and the north is a war against the LTTE and not against the Tamil population, this is believed to have significantly reduced communal violence. The bodies of 300 policemen captured in 1991 were recovered. Local Government elections held in May are considered free and fair. Opposition tried to impeach the President.

1992: Peaceful resolution of the conflict was complicated even further. LTTE escalated its attacks on the Muslim and Sinhalese population in an effort to drive the communities out of the Tamil provinces. As a result of this armed Muslim groups masacred innocent civilians. Some 200 people disappeared (attributed largely to security forces), which is a sharp decline of previous years. 650 civilians died of extrajudicial killings or combat related deaths. There seems to an effort to stop human rights abuses by the Government. Attacks on civilians by Government forces appear to be the result of lapses of discipline rather than policy decisions. Members of opposition groups were increasingly harassed.

1993: On May 1 President Premadasa is assassinated by an LTTE suicide bomber. President Dingiri Banda Wijetunga is chosen by the Parliament to succeed Premadasa. About 70 people disappeared in the first nine months of the year (a significant decline from the previous year). LTTE are also responsible for disappearance, however it is not known how many. It is widely believed that the decision to grant the ICRC unhindered access to detention centers, police stations and army camps has played an important role in reducing the number of disappearances. There was a lull in fighting during the first nine months of the year, but the 
fighting reached new level of intensity in the $4^{\text {th }}$ quarter of the year, as both sides launched major offensives. There were increasing attacks on civilian targets by the Sri Lankan army. Thee was an increased use of curfews and checkpoints by the Army and LTTE which made travel within the country difficult. Especially for young Tamil men, and especially after the killing of the President. After the death of the President, organised harassment of the opposition ceased.

1994: In generally free and fair elections the People's Alliance ended the 17 year control of Parliament by the United National Party, and Chandrika Kumaratunga, became Prime Minister. A dialogue was initiated with the LTTE. Security forces committed significantly less human rights abuses than in previous years. The United National Party's candidate for the elections was killed in a suicide attack. Suspects in several extrajudicial killings were prosecuted. In most of the country ER were lifted, this made concealment of extrajudicial killings and disappearances difficult. Travel restrictions were eased, but remained strict for young Tamil men.

1995: Cessation of hostilities on January 3. The truce was broken when LTTE attacked security forces in April. Governmental forces succeeded in capturing the unofficial capital of the rebels, Jaffna City, after major offensives. During cessation governmental forces committed very few human rights abuses. With the resumption of hostilities the number of abuses increased. The Government moved to correct the worst relapses. The JVP is legalised. Travel restrictions were once more applied more strictly. This affected young Tamil men in their freedom of movement. 1996: A six month military offensive captured the LTTE heartland of the Jaffna Peninsula in April. The LTTE inflicted a major military defeat on Government forces at a military base in the North killing upwards of 1,500 troops. Intensification of the conflict meant a deterioration in the human rights situation. In April the ER was reimposed nationwide. There was no evidence the ER were used to conceal extrajudial executions or disappearances. However crucial protective safeguards were frequently ignored. Civilian casualties in the renewed fighting were limited, because security forces showed much greater restraint in the use of excessive force. Moreover troops advanced slowly and methodically. Travel restrictions were once more applied more strictly. This affected young Tamil men in their freedom of movement. Local elections were postponed by the President under ER.

1997: In May the Government forces launched a major new offensive aimed at opening a land route to the Jaffna Peninsula through LTTE controlled territory. The offensive resulted in hundreds killed. The Government generally respected the human rights of its citizens in areas not affected by the conflict. ER was lifted outside of the north and east and Colombo. Violence between supporters of the major political parties worsened and six people including a member of Parliament were killed in violence related to local government electionsin March. Civilian casualties were limited in the first six months of the year, because security forces showed much greater restraint in the use of excessive force. Moreover troops advanced slowly and methodically. Elections in the Jaffna Peninsula were postponed untill January 1998.

1998: The conflict between LTTE and the Sri Lankan Government has claimed over 55,000 lives so far. The offensive launched in May 1997 ended in December and claimed approx. 5,000 combattant deaths on both sides. State of emergency was reimposed nationwide.

1999: The President scheduled early Presidential elections in December. She won the generally free and fair elections. However the preelection and election period were marred by violence. At least six persons were killed and there was an unsuccessfull assassination attempt on the President by the LTTE. The whole conflict between the government and the LTTE has claimed 60,000 lives so far. The Government gained much territory in a series of offensives. In a counterattack the LTTE regained much of the territory lost in the last two years.More than a thousand combattants were killed in the fighting. Sine April 1995 at least 761 persons have been extrajudicially killed by security forces or have disappeared and are presumed dead.

2000: Violence and fraud marked the October parliamentary elections. At least seven persons died in election related violence. The elections resulted in a reduced majority of the PA. The conflict between Government and LTTE claimed 62,000 lives so far. A major offensive on the Jaffna Peninsula left many dead (civilians and combatants). Violent clashes continued during the year. More than 2,000 combattants and more than 100 civilians were killed in incidents 
related to the conflict. The army was more secretive about missions than in previous years. The publicity given to offensives in the past limited civilian casualties. Tamils are frequently harassed at checkpoints.

2001: Parliamentary elections in December were marred by violence, at least 50 deaths, and irregularities (including the refusal to allow 40,000 Tamils to vote). A coaltion lead by the UNP won a majority in Parliament. The conflict has claimed at least 64,000 lives untill now. In April government forces launched a major offensive on the Jaffna Peninsula, this resulted in heavy losses. In July LTTE attacked Colombo's international airport. At year's end the Governmetn and the LTTE had each announced unilateral cease-fires. It is believed as many as 2,000 combattants and 100 civilians were killed in conflict-related incidents. The army was more secretive about missions than in previous years. The publicity given to offensives in the past limited civilian casualties. Tamils are frequently harassed at checkpoints.

2002: The Government and LTTE started a historic process of reconciliation in December 2001. This process continued in Norwegian-facilitated talks in Thailand and Norway. The talks were successful and will continue into 2003. As a result of the peace there was sharp reduction in roadblocks and checkpoints around the country, the return of 220,000 internally displaced persons, and the opening of investigations into questionnable actions by security forces. On September 4 the LTTE was legalized.

${ }^{1}$ Human rights abuses that can be attributed to the LTTE will be dealt with in a separate table. This table will not deal with abuses by the Indian Peace Keeping Forces and the JVP. However they will be mentioned in the brief historical/political overview and in the conflict level. This is due to the fact that deaths attributed to IPKF and JVP can not be separated from deaths attributed by other organisations or the Government.

28,500 deaths, mainly civilians.

${ }^{3} 2,600$ non combatant $/ 5,200$ combatant deaths

470 non combatant/7,100 combatantant deaths.

${ }^{5} 650$ civilian deaths.

${ }^{6}$ Political killings remains the main problem in Sri Lanka. It is difficult to distinguish between politically motivated killings and criminal killings. During the conflict 5,600 civilians were killed. There are also a great number of disappeared. Many disappeared at the hands of security forces. Circumstances strongly suggest that some "disappeared" have been killed by security forces.

${ }^{7}$ There are probably several thousand of children who work illegally mostly at jobs in rice cultivations, as domestics, or as street peddlers. In some cases these children are a major source of income for the family.

${ }^{8}$ Many non combatant deaths. Also, in the fight against the JVP 200 (suspected) members were killed. Many of these deaths are extrajudicial killing. Political killings still remains the main human rights problem. Many vigilante killings can be attributed to security force members. Reports indicate security forces rounded up large groups of Tamils and sumarilly executed them. "Disappeared" were in some cases killed by security forces. Security forces killed over 1,000 Tamilsin the Eastern distric between June and September.

${ }^{9}$ It is difficult to ascertain exactly how bad conditions are. They are in any case harsher for security detainees (those held under ER measures). They are held in army stockades and prison camps. These prisoners are not under the jurisdiction of the prisons department. Beatings and torture do occur in such facilities.

10 There are probably several thousand of children who work illegally mostly at jobs in rice cultivations, as domestics, or as street peddlers. In some cases these children are a major source of income for the family.

11710 non combatant deaths. Roughly 380 of these deaths were war related accidental deaths. There were a number of anti-JVP vigilante deaths. However this year there were no clear indications the vigilante deaths could be attributed to the Governemnt. Vigilante killings in the east were probably the work of security forces.

${ }^{12}$ Especially in the east and the south against suspected members of thre JVP and the LTTE.

${ }^{13}$ Stateless Tamils living in Sri Lanka's tea-growing highlands have suffered particular discrimination, especially in the allocation of education funds.

${ }^{14} 500,000$ youths are employed in breach of regulations on child labor. 10,000 are begging on the streets. There are probably tens of thousands of children who work illegally on farms or as domestics or in other menial jobs.

${ }^{15}$ There are an estimated 20,000 youths under the age of 18 working in prostitution.

${ }_{16}$ An estimated 10,000 children are begging on the streets. It is unclear whether they also live on the streets.

${ }^{17}$ At least 125 were reliably attributable to deliberate attacks by government forces. Most occurred in Sri Lanka's Eastern Province. There were less than ten reports of extrajudicial killings in the south. However the record of security forces in the Battacaloa district, an eastern province, was particlurly bad. Government troop have been accused of numerous extrajudicial executions of suspected LTTE cadres and civilians fleeing the army. Quasiindependent irregular forces armed by the Government (anti-LTTE -militias) have been responsible for roughly 120 deaths.

18 Torture was routinely applied during interrogations. Many detainees reported being tortured. Women are sometimes sexually abused.

${ }^{19}$ Stateless Tamils living in Sri Lanka's tea-growing highlands have suffered particular discrimination, especially in the allocation of education funds. 
${ }^{20} 500,000$ children between the age of 10 and 14 work in the informal labor market. Children work in farming, rice milling, coir production, fisheries, passenger transport, and street vending. Many children in Colombo work as domestics.

${ }^{21}$ There are an estimated 20,000 youths under the age of 18 working in prostitution.

${ }^{22}$ Number of civilian deaths drops (250 by security forces).

${ }^{23}$ Number of civilian deaths drops (150 by security forces).

${ }^{24}$ The number of political/extrajudicial killings decreased significantly. There were no reprisal attacks on Tamil civilians (as there were no massacres of Muslim/Sinhalese civilians by LTTE) and there were no reported vigilante killings in the south. Even though there still were 250 civilians killed during military operations most of these deaths were the result of indiscriminate use of force and not as in previous years, deliberate attacks on civilians. However there still were a number of extrajudicial executions. Moreover more than 80 people disappeared or died after being taken into custody by security forces.

${ }^{25}$ Torture was common, especially during interrogation. Common criminals as well as detainees under ER were tortured. In the early stages of detention detainees were frequently severely beaten.

${ }^{26}$ Stateless Tamils living in Sri Lanka's tea-growing highlands have suffered particular discrimination, especially in the allocation of education funds.

${ }^{27}$ There are reports of abuse of rural children working as domestics in urban households (starvation, beatings, burnings, sexual abuse, and forces prostitution).

${ }^{28}$ Despite legislation, some child labor still exists. Some children work in the informal sectors, including coirmaking, which is the making of products, such as mats, from coconut fiber, industries; fishing; drying fish; wrapping tabacco; street trading; domestic service and on farms. There are reports of abuse of children brought in from rural areas in debt bondage to work as domestic servants in urban households (they are in some cases forced into prostitution).

${ }^{29}$ Child prostitution is a significant problem, especially in coastal areas. The majority of these prostitutes are boys. There are several thousand children thought to be involved.

${ }^{30}$ There were ten disappearances. These disappeared were last seen taken into police custody and are presumed dead. All disappearances occurred in the first part of the year. There were no extrajudicial executions. However some 150 civilians were killed by the indiscriminate or excessive use of force by security forces. The air force introduces new rules of engagement and security forces received human rights training courses, in an effort to reduce the number of civilian casualties.

${ }^{31}$ When we look only at extrajudicial executions that are not directly linked to the conflict, thus excluding excessive violence in attacks and deliberate killings of civilians in combat, we see such a sharp decrease in the amount of disappearances (10) and other extrajudicial executions (none) that a small 'e' would be justified. In the rest of the table (apart from 2002) the 'E' remains big, because even when the extrajudicial executions directly linked to the conflict are not counted, there are still a high amount of disappearances and other extrajudicial executions. Putting a small 'e' here emphasises the fact the violence from the conflict had a direct impact on extrajudicial executions and the cease fire was effective in bringing the number of extrajudicial executions significantly down.

${ }^{32}$ Overcrowding and lack of sanitary facilities are the most important problems.

${ }^{33}$ Torture was common, especially during interrogation. Victims were especially alleged LTTE members and JVP members. The number of reports of torture was somewhat lower. In January the Government acceded to the U.N. Convention against Torture and Othe Cruel, Inhuman or Degrading Treatment or Punishment.

${ }^{34}$ Stateless Tamils living in Sri Lanka's tea-growing highlands have suffered particular discrimination, especially in the allocation of education funds.

${ }^{35}$ There are reports of abuse of rural children working as domestics in urban households (starvation, beatings, burnings, sexual abuse, and forces prostitution).

${ }^{36}$ Despite legislation, some child labor still exists. Some children work in the informal sectors, including coirmaking, which is the making of products, such as mats, from coconut fiber, industries; fishing; drying fish; wrapping tabacco; street trading; domestic service and on farms. There are reports of abuse of children brought in from rural areas in debt bondage to work as domestic servants in urban households (they are in some cases forced into prostitution).

${ }^{37}$ Child prostitution is a significant problem, especially in coastal areas. The majority of these prostitutes are boys. According to a Governemnt report there are 2,000 child prostitutes. However NGO's believe this figure is much higher.

${ }^{38}$ At least 38 extrajudicial killings. In some cases civilians were murdered in reprisal for killings of security forces. In August extrajudicial killings ceased when members of the security forces were arrested. There were 34 disappearances, they are presumed dead. In two military offensives against Jaffna City some 400 civilians were killed. However the security forces tried to minimalise the number of civilian casualties and were quite successful in that.

${ }^{39}$ Overcrowding and lack of sanitary facilities are the most important problems. With the resumption of the war and the subsequent increase of security detainees poor prison conditions deteriorated even further.

${ }^{40}$ Torture was common, especially during interrogation. Victims were especially alleged LTTE members.JVP members were no longer the victim of torture as the party was legalised. The number of reports of torture was somewhat lower. 
${ }^{41}$ Stateless Tamils living in Sri Lanka's tea-growing highlands have suffered particular discrimination, especially in the allocation of education funds.

${ }^{42}$ There are reports of abuse of rural children working as domestics in urban households (starvation, beatings, burnings, sexual abuse, and forces prostitution). In the first quarter the Government reported that 1,576 cases of crimes against children had been recorded.

${ }^{43}$ Despite legislation, some child labor still exists. Some children work in the informal sectors, including coirmaking, which is the making of products, such as mats, from coconut fiber, industries; fishing; drying fish; wrapping tabacco; street trading; domestic service and on farms. There are reports of abuse of children brought in from rural areas in debt bondage to work as domestic servants in urban households (they are in some cases forced into prostitution).

${ }^{44}$ Child prostitution is a significant problem, especially in coastal areas. The majority of these prostitutes are boys. According to a Governemnt report there are 2,000 child prostitutes. However NGO's believe this figure is much higher.

${ }^{45}$ Police and army personnel committed extrajudicial killings in both Jaffna and the Eastern Provinces. Most were associated with operations against the LTTE insurgents or interrogation of suspected rebels. 50 people were killed, however the number might be higher. There is not enough information due to military censorship.In some cases the killings were reprisals for rebel attacks on security forces. A pro-government Tamil militia was responsible for a number of killings. However it is unknown how much influence the government exercises on the militias. In excess of 300 individuals are believed to have disappeared on the Jaffna Peninsula in the second half of the year, and more than 50 elsewhere in the country. These people are presumed dead. (the figure is impossible to verify because of military censorship). Progovernment Tamil militias were also responsible for a number of disappearances.

${ }^{46}$ Overcrowding and lack of sanitary facilities are the most important problems. An increase in security detainees meant poor prison conditions deteriorated even further.

${ }^{47}$ Torture was common, especially during interrogation. Victims were especially alleged LTTE members. The number of reports of torture was somewhat lower. However in the Jaffna Peninsula the situation did not improve.

${ }^{48}$ Stateless Tamils living in Sri Lanka's tea-growing highlands have suffered particular discrimination, especially in the allocation of education funds.

${ }^{49}$ There are reports of abuse of rural children working as domestics in urban households (starvation, beatings, burnings, sexual abuse, and forces prostitution). In the first half of the year the Government reported that 3,687 cases of crimes (of all types) against children had been recorded.

${ }^{50}$ Despite legislation, some child labor still exists. According to a Labor Department survey 20,600 children between the ages of 10 and 14 were fully employed. Additionnal thousands of children were blieved to be employed in domestic service. In addition to domestic service regular employment of children work in the informal sectors and in family enterprises. Additionnally some children work in coir-making, which is the making of products, such as mats, from coconut fiber, industries; fishing; drying fish; wrapping tabacco; street trading; Allthough forced and compulsory labor is virtually non existent there are reports of a few rural children who are employed in debt bondage as domestic servants in urban households.

${ }^{51}$ Child prostitution is a significant problem, especially in coastal areas. The majority of these prostitutes are boys. According to a Governemnt report there are 2,000 child prostitutes. However NGO's believe this figure is much higher.

${ }_{52}$ Less than 4000 deaths. Figure is from the SIPRI Yearbook 1998, figures to be found on http://first.sipri.org/index.php?page=step2.

${ }_{53}$ Less than 4000 deaths. Figure is from the SIPRI Yearbook 1999, figures to be found on http://first.sipri.org/index.php?page=step2.

${ }_{54}$ More than 3500 deaths. Figure is from the SIPRI Yearbook 2000, figures to be found on http://first.sipri.org/index.php?page=step2.

${ }_{55}$ More than 4000 deaths. Figure is from the SIPRI Yearbook 2001, figures to be found on http://first.sipri.org/index.php?page=step2. The state department report mentions the following figures: More than 2000 combatants dead, and more than 100 civilians dead.

${ }^{56}$ Police and army personnel committed extrajudicial killings in both Jaffna and the Eastern Provinces. Most were associated with operations against the LTTE insurgents or interrogation of suspected rebels. 100 people were killed, however the number might be higher. There is not enough information due to military censorship.In some cases the killings were reprisals for rebel attacks on security forces. A pro-government Tamil militia was responsible for a number of killings. However it is unknown how much influence the government exercises on the militias. At least 125 people disappeared. These people are presumed dead. (the figure is impossible to verify because of military censorship). Progovernment Tamil militias were also responsible for a number of disappearances.

${ }^{57}$ Overcrowding and lack of sanitary facilities are the most important problems. An increase in security detainees meant poor prison conditions deteriorated even further.

${ }^{58}$ Torture continued. Especially Tamils suspected of being LTTE insurgents or collaborators were victims. Progovernment Tamil militias were also responsible of torture.

${ }^{59}$ Stateless Tamils living in Sri Lanka's tea-growing highlands have suffered particular discrimination, especially in the allocation of education funds. 
${ }^{60}$ There are reports of abuse of rural children working as domestics in urban households (starvation, beatings, burnings, sexual abuse, and forces prostitution). In the first half of the year the Government reported that 1,633 cases of crimes (of all types) against children had been recorded.

${ }^{61}$ Despite legislation, some child labor still exists. According to a Labor Department survey 26,000 children between the ages of 10 and 14 were fully employed. Additionnal thousands of children (between 50,000 and $100,000)$ were blieved to be employed in domestic service. In addition to domestic service regular employment of children work in the informal sectors and in family enterprises. Additionnally some children work in coir-making, which is the making of products, such as mats, from coconut fiber, industries; fishing; drying fish; wrapping tabacco; street trading; Allthough forced and compulsory labor is virtually non existent there are reports of a few rural children who are employed in debt bondage as domestic servants in urban households.

${ }^{62}$ Child prostitution is a significant problem, especially in coastal areas. The majority of these prostitutes are boys. According to a Governemnt report there are 2,000 child prostitutes. However NGO's believe this figure is much higher.

${ }^{63}$ Police and army personnel committed extrajudicial killings. Most were associated with operations against the LTTE insurgents or interrogation of suspected rebels. 33 people were killed and in at least 18 other cases people were killed near the Army's forward defense lines, however the number might be higher. Security force bombs and artillery fire also killed civilians. There is not enough information due to military censorship.In some cases the killings were reprisals for rebel attacks on security forces. Security forces seem to have killed many rebels after they were captured.Pro-government Tamil militants were responsible for a number of killings. However it is unknown how much influence the government exercises on the militias. At least 11 people disappeared. These people are presumed dead. (the figure is impossible to verify because of military censorship). Progovernment Tamil militias were also responsible for a number of disappearances.

${ }^{64}$ Overcrowding and lack of sanitary facilities are the most important problems. An increase in security detainees meant poor prison conditions deteriorated even further in short-term detention centers.

${ }^{65}$ Torture continued. Especially Tamils suspected of being LTTE insurgents or collaborators were victims. Though torture was still widespread its use diminished, especially in Jaffna. Progovernment Tamil militias were also responsible of torture.

${ }^{66}$ Stateless Tamils living in Sri Lanka's tea-growing highlands have suffered particular discrimination, especially in the allocation of education funds.

${ }^{67}$ There are reports of abuse of rural children working as domestics in urban households (starvation, beatings, burnings, sexual abuse, and forces prostitution). In the first half of the year the Government reported that 1,752 cases of crimes (of all types) against children had been recorded. A new Child Protection Authority Bill was passed through Parliament and welcomed by NGO's.

${ }^{68}$ Despite legislation, some child labor still exists. According to a Labor Department survey 16,511 children between the ages of 10 and 14 were fully employed. Additionnal thousands of children (between 50,000 and 100,000 ) were blieved to be employed in domestic service. Those working in domestic work are often subjected to physical, sexual, and/or other emotional abuse. A significant portion of the children work outside their families. In addition to domestic service regular employment of children work in the informal sectors and in family enterprises. Additionnally some children work in coir-making, which is the making of products, such as mats, from coconut fiber, industries; fishing; drying fish; wrapping tabacco; street trading; Allthough forced and compulsory labor is virtually non existent there are reports of a few rural children who are employed in debt bondage as domestic servants in urban households.

${ }^{69}$ Child prostitution is a significant problem, especially in coastal areas. The majority of these prostitutes are boys. According to a Governemnt report there are 2,000 child prostitutes. However NGO's and the UN believe this figure is much higher (somewhere between 15,000 to 30,000 ).

${ }^{70}$ Security forces closed three rooming hotels and left hundreds of Tamils temporarily without lodging.

${ }^{71}$ Police, home guards, and army personnel committed extrajudicial killings in many places. The excact number of killings wasimpossible to determine because of military censorship. However the report names at least seven killings (one in custody) and at least 57 civilian deaths in fighting.In some cases the killings were reprisals for attacks on security personnel. Progovernment Tamil militant groups were responsible for an undetermined amount of killings. It is difficult to see how much influence the government exercises on these groups. There were at least 15 disappearances in the North and the East. However the excact number of disappearances is impossible to determine because of military censorship. The disappeared are presumed dead. Progovernment Tamil militants were also responsible for disappearances. Instead of taking LTTE combattant prisoner it is believed they are killed upon captivity.

${ }^{72}$ Overcrowding and lack of sanitary facilities are the most important problems. The conflict lead to an increase of security detainees which meant poor prison conditions deteriorated even further in short term detention centers and undeclared detention centers run by progovernment Tamil groups.

${ }^{73}$ Most torture victims were Tamils suspected of being LTTE insurgents or collaborators, however there also have been sporadic reports of the use of torture against suspected criminals. One person died in custody as a result of a severe beating. Progovernment Tamil militants also use torture routinely.

${ }^{74}$ Stateless Tamils living in Sri Lanka's tea-growing highlands have suffered particular discrimination, especially in the allocation of education funds. 
${ }^{75}$ There are reports of abuse of rural children working as domestics in urban households (starvation, beatings, burnings, sexual abuse, and forces prostitution). In the first quarter the Government reported that 2,066 cases of crimes against children had been recorded.

${ }^{76}$ Despite legislation, some child labor still exists. It is estimated 16,000 children between the age of 10 and 14 may be fully employed. Additionnal thousands are belived to be working in domestic service (between 50,000 and 100,000). Some children work in the informal sectors, including coir-making, which is the making of products, such as mats, from coconut fiber, industries; fishing; drying fish; wrapping tabacco; street trading, and on farms. There are reports of abuse of children brought in from rural areas in debt bondage to work as domestic servants in urban households (they are in some cases forced into prostitution).

${ }^{77}$ Child prostitution is a significant problem, especially in coastal areas. The majority of these prostitutes are boys. According to a Governemnt report there are 2,000 child prostitutes. However NGO's believe this figure is much higher (somewhere between 15,000 and 30,000).

${ }^{78}$ There were credible reports of children being trafficked in to the country. There also was trafficking inside the country.

${ }^{79}$ Repeated closures of the border into LTTE controlled territory meant the distribution of food in the North was erratic. NGO's believe these closures had an impact on food reserves in the Vanni area and may have led to worsened nutrition there.

${ }^{80}$ Police, home guards, and army personnel committed extrajudicial killings in many places. The excact number of killings was impossible to determine because of military censorship. In one incidents police alledgedly looked on and participated in the slaying of 27 Tamil males who were detained in a Government run rehabilitation camp. The victims were former child soldiers. This incident caused an eruption of violence which killed at least 14 people before the police could restore order a week later. In some cases the killings were reprisals for attacks on security personnel. Progovernment Tamil militant groups were responsible for an undetermined amount of killings. It is difficult to see how much influence the government exercises on these groups. There were at least 11 disappearances in the North and the East. However the excact number of disappearances is impossible to determine because of military censorship. NGO's such as AI have reported an increase in the number of disappearances in the second half of the year. The disappeared are presumed dead. Progovernment Tamil militants were also responsible for disappearances. Instead of taking LTTE combattant prisoner it is believed they are killed upon captivity. Many civilians were killed in fighting.

${ }^{81}$ Overcrowding and lack of sanitary facilities are the most important problems. The conflict lead to an increase of security detainees which meant poor prison conditions deteriorated even further in short term detention centers and undeclared detention centers run by progovernment Tamil groups.

${ }^{82}$ Most torture victims were Tamils suspected of being LTTE insurgents or collaborators, however there also have been reports of the use of torture against suspected criminals. Some children also were tortured. One person died in custody as a result of a severe beating. Progovernment Tamil militants also use torture routinely. It is widely believed the PTA contributes to the use of torture.

${ }^{83}$ Stateless Tamils living in Sri Lanka's tea-growing highlands have suffered particular discrimination, especially in the allocation of education funds. Children working as domestics in homes in the south are deprived of access to education.

${ }^{84}$ In the first half of the year the Government reported 767 cases of crimes against children had been recorded. Many children working as domestics suffer from physical, sexual, emotional abuse.

${ }^{85}$ Some children work in the plantation sectors and in nonplantation agriculture. Almost 11,000 children work full-time. Another 15,000 are engaged in both economic activity and housekeeping. Some 450,000 children are employed by their families in seasonal agricultural work. $8.6 \%$ of homes in the south employ children as domestic servants. Many of these children suffer from physical, sexual, and emotional abuse. Regular employment of children also takes place mainly in the informal sector and in family enterprises.

${ }^{86}$ Child prostitution is a significant problem, especially in coastal areas. The majority of these prostitutes are boys. According to a Governemnt report there are 2,000 child prostitutes. However the UN believes there are 30,000 child prostitutes.

${ }^{87}$ There were credible reports of children being trafficked in to the country. There also was trafficking inside the country, especially from the North and the East.

${ }^{88}$ LTTE expropriates food further exacerbating the plight of such persons in LTTE controlled territory. Malnutrition remained a problem in LTTE controlled territory and other parts of the Vanni region. Malnutrition caused an increase in anemia and a lower birth rate. Malnutrition is caused among others by food shortages. However Medecins sand Frontieres found malnutrition to be at about the same level as in war-free South. The report states that there are many undernourished children in the country.

${ }^{89}$ More than 1000 deaths. Figure is from the SIPRI Yearbook 2002, figures to be found on http://first.sipri.org/index.php?page=step2.

90 Less than 25 deaths. Figure is from the SIPRI Yearbook 2003, figures to be found on http://first.sipri.org/index.php?page=step2.

${ }^{91}$ Police, home guards, and army personnel committed extrajudicial killings in many places. Including the killing of civilians in connection with the conflict with the LTTE. The excact number of killings was impossible to determine because of military censorship. In one incidents police alledgedly looked on and participated in the slaying of 27 Tamil males who were. In some cases the killings were reprisals for attacks on security personnel. Progovernment Tamil militant groups were responsible for an undetermined amount of killings. It is difficult to 
see how much influence the government exercises on these groups. Army, navy, police and paramilitary groups were involved in at least 10 disappearances primarily in Vavuniya. Between January and September the HRC received 44 reports of disappearances. The excact number of disappearances is impossible to determine because of military censorship. The disappeared are presumed dead. Progovernment Tamil militants were also responsible for disappearances.

${ }^{92}$ Overcrowding and lack of sanitary facilities are the most important problems. The conflict lead to an increase of security detainees which meant poor prison conditions deteriorated even further in short term detention centers and undeclared detention centers run by progovernment Tamil groups.

${ }^{93}$ Most torture victims were Tamils suspected of being LTTE insurgents or collaborators, however there also have been reports of the use of torture against suspected criminals. Rape is also used as a method of torture. Progovernment Tamil militants also use torture routinely. It is widely believed the PTA contributes to the use of torture.

${ }^{94}$ Stateless Tamils living in Sri Lanka's tea-growing highlands have suffered particular discrimination, especially in the allocation of education funds. Children working as domestics in homes in the south are deprived of access to education.

${ }^{95}$ In the first half of the year the Government reported 680 cases of crimes against children had been recorded. Many children working as domestics suffer from physical, sexual, emotional abuse.

${ }^{96}$ Some children work in the plantation sectors and in nonplantation agriculture. Almost 11,000 children between 5 and 14 work full-time. Another 15,000 are engaged in both economic activity and housekeeping. Some 450,000 children are employed by their families in seasonal agricultural work. $8.6 \%$ of homes in the south employ children as domestic servants. Many of these children suffer from physical, sexual, and emotional abuse. Regular employment of children also takes place mainly in the informal sector and in family enterprises. An awareness campaign on child labor lead to an increased number of prosecutions.

${ }^{97}$ Child prostitution is a significant problem, especially in coastal areas. The majority of these prostitutes are boys. According to a Governemnt report there are 2,000 child prostitutes. However the UN believes there are 30,000 child prostitutes.

${ }^{98}$ There were credible reports of children being trafficked in to the country. There also was trafficking inside the country, especially from the North and the East. Boys are being trafficked to the Middle East to work as camel jockeys.

99 LTTE expropriates food further exacerbating the plight of such persons in LTTE controlled territory. Malnutrition remained a problem in LTTE controlled territory and other parts of the Vanni region. Malnutrition caused an increase in anemia and a lower birth rate. Malnutrition is caused among others by food shortages. However Medecins sand Frontieres found malnutrition to be at about the same level as in war-free South. The report states that there are many undernourished children in the country.

${ }^{100}$ A number of persons were killed by security forces. Alledgedly they used excessive force.

${ }^{101}$ Overcrowding and lack of sanitary facilities are the most important problems.

${ }^{102}$ Especially during interrogation.

${ }^{103}$ Stateless Tamils living in Sri Lanka's tea-growing highlands have suffered particular discrimination, especially in the allocation of education funds. Children working as domestics in homes in the south are deprived of access to education.

${ }^{104}$ In the first ten months of the year the Government reported 613 cases of pedophilia against children had been recorded. Many children working as domestics suffer from physical, sexual, emotional abuse.

${ }^{105}$ Some children work in the plantation sectors and in nonplantation agriculture. Almost 11,000 children between 5 and 14 work full-time. Another 15,000 are engaged in both economic activity and housekeeping. Some 450,000 children are employed by their families in seasonal agricultural work. $8.6 \%$ of homes in the south employ children as domestic servants. Many of these children suffer from physical, sexual, and emotional abuse. Regular employment of children also takes place mainly in the informal sector and in family enterprises. An awareness campaign on child labor lead to an increased number of prosecutions. Some children have served in debt bondage.

${ }^{106}$ Child prostitution is a significant problem, especially in coastal areas. The majority of these prostitutes are boys. According to a Governemnt report there are 2,000 child prostitutes. However the UN believes there are 30,000 child prostitutes.

${ }^{107}$ There were credible reports of children being trafficked in to the country. There also was trafficking inside the country, especially from the North and the East. There were unconfirmed reports that boys are being trafficked to the Middle East to work as camel jockeys.

${ }^{108}$ LTTE expropriates food further exacerbating the plight of such persons in LTTE controlled territory. Malnutrition remained a problem in LTTE controlled territory and other parts of the Vanni region. Malnutrition caused an increase in anemia and a lower birth rate. Malnutrition is caused among others by food shortages. However Medecins sand Frontieres found malnutrition to be at about the same level as in war-free South. The report states that there are many undernourished children in the country. 


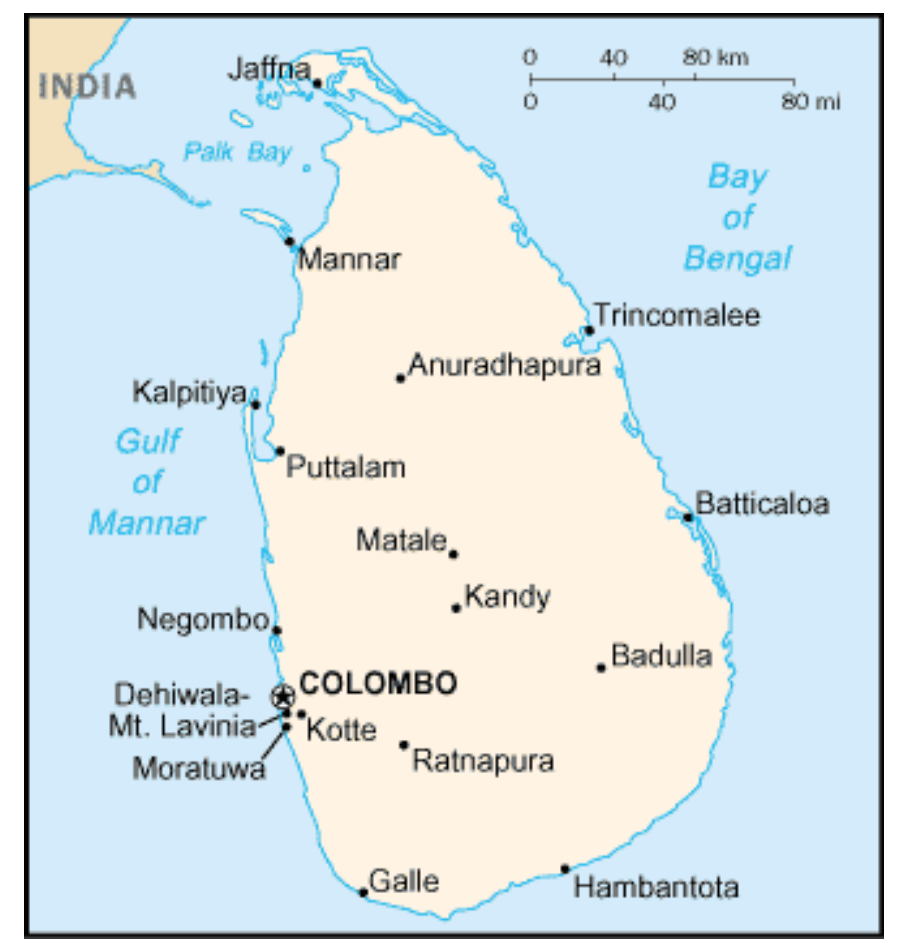

\section{LTTE}

\begin{tabular}{|c|c|c|c|c|}
\hline $\mathbf{1 9 8 9}$ & $\mathbf{1 9 9 0}$ & $\mathbf{1 9 9 1}$ & $\mathbf{1 9 9 2}$ \\
\hline $\begin{array}{c}\text { Political } \\
\text { Terrorscale }\end{array}$ & $5 / 5$ & $5 / 5$ & $5 / 4$ & $5 / 4$ \\
\hline Conflict Level & $\begin{array}{c}\text { High level conflict } \\
(8,500 \text { deaths, mainly } \\
\text { civilians })\end{array}$ & $\begin{array}{c}\text { High level conflict } \\
(2,600 \text { non } \\
\text { combatant } / 5,200)\end{array}$ & $\begin{array}{c}\text { High level conflict } \\
(710 \text { non } \\
\text { combatant } / 7,100)\end{array}$ & $\begin{array}{c}\text { High level conflict } \\
(650 \text { civilian deaths })\end{array}$ \\
\hline $\begin{array}{c}\text { Freedom } \\
\text { House }\end{array}$ & $\mathrm{E},(\mathrm{T})^{1}$ & $\mathrm{E}^{2},(\mathrm{~T})^{3}, \mathrm{FE}^{4}$ & $\mathrm{E}^{5},(\mathrm{~T})^{6}$ & $\mathrm{E}^{7},(\mathrm{~T})^{8}$ \\
\hline $\begin{array}{c}\text { U.S. State } \\
\text { Department }\end{array}$ & & &
\end{tabular}

\begin{tabular}{|c|c|c|c|c|}
\hline $\begin{array}{c}\text { Political } \\
\text { Terrorscale }\end{array}$ & $5 / 4$ & $\mathbf{1 9 9 4}$ & $\mathbf{1 9 9 5}$ & 1996 \\
\hline $\begin{array}{c}\text { Conflict Level } \\
\text { Freedom } \\
\text { House }\end{array}$ & $\begin{array}{c}\text { Number of civilian } \\
\text { deaths drops (250 by } \\
\text { security forces) }\end{array}$ & $\begin{array}{c}\text { Number of civilian } \\
\text { deaths drops }(150 \text { by } \\
\text { security forces) }\end{array}$ & $4 / 5$ & $5 / 4$ \\
\hline $\begin{array}{c}\text { U.S. State } \\
\text { Department }\end{array}$ & $\mathrm{E}^{9}, \mathrm{CL} / \mathrm{FL}^{10}$ & $\begin{array}{c}\mathrm{E}^{11},(\mathrm{p})^{12},(\mathrm{~T})^{13}, \\
\mathrm{CL} / \mathrm{FL}\end{array}$ & $\begin{array}{c}\text { High intensity } \\
\text { conflict }\end{array}$ \\
\hline
\end{tabular}




\begin{tabular}{|c|c|c|c|c|}
\hline $\begin{array}{c}\text { Political } \\
\text { Terrorscale }\end{array}$ & 1997 & 1998 & 1999 & $\mathbf{2 0 0 0}$ \\
\hline $\begin{array}{c}\text { Conflict Level } \\
\text { Freedom } \\
\text { House }\end{array}$ & $\begin{array}{c}\text { high intensity } \\
\text { conflict }\end{array}$ & $\begin{array}{c}\text { high intensity } \\
\text { conflict }\end{array}$ & $\begin{array}{c}\text { high intensity } \\
\text { conflict }\end{array}$ & $\begin{array}{c}\text { high intensity } \\
\text { conflict (more than } \\
2000)\end{array}$ \\
\hline $\begin{array}{c}\text { U.S. State } \\
\text { Department }\end{array}$ & $\begin{array}{c}\mathrm{E}^{25},(\mathrm{p})^{26},(\mathrm{~T})^{27}, \\
\mathrm{CL} / \mathrm{FL}^{28}, \mathrm{R}^{29}\end{array}$ & $\begin{array}{c}\mathrm{E}^{30}, \mathrm{p}^{31},(\mathrm{~T})^{32}, \mathrm{CS}^{33}, \\
\mathrm{CL} / \mathrm{FL}^{34}, \mathrm{IF}^{35}\end{array}$ & $\begin{array}{c}\mathrm{E}^{36}, \mathrm{p}^{37},(\mathrm{~T})^{38} \\
\mathrm{CL}^{38}, \mathrm{FS}^{40}, \\
\mathrm{IF}^{41}, \mathrm{R}^{4},\end{array}$ & $\begin{array}{c}\mathrm{E}^{42}, \mathrm{p}^{43},(\mathrm{~T})^{44} \\
\mathrm{IF}^{47}, \mathrm{CS}^{46},\end{array}$ \\
\hline
\end{tabular}

\begin{tabular}{|c|c|c|}
\hline & 2001 & 2002 \\
\hline \multicolumn{3}{|l|}{$\begin{array}{l}\text { Political } \\
\text { Terrorscale }\end{array}$} \\
\hline Conflict Level & $\begin{array}{l}\text { High intensity } \\
\text { conflict }\end{array}$ & $\begin{array}{l}\text { Violent political } \\
\text { conflict }\end{array}$ \\
\hline \multicolumn{3}{|l|}{$\begin{array}{l}\text { Freedom } \\
\text { House }\end{array}$} \\
\hline $\begin{array}{c}\text { U.S. State } \\
\text { Department }\end{array}$ & $\begin{array}{l}\mathrm{E}^{48}, \mathrm{p}^{49},(\mathrm{~T})^{50}, \mathrm{CS}, \\
\mathrm{CL} / \mathrm{FL}^{51}, \mathrm{R}^{52}, \mathrm{IF}^{53}\end{array}$ & $\begin{array}{c}(\mathrm{e})^{54}, \mathrm{p}^{55},(\mathrm{~T})^{56}, \mathrm{CS}, \\
\mathrm{CL} / \mathrm{FL}^{57}, \mathrm{IF}^{58}\end{array}$ \\
\hline
\end{tabular}

\section{Working conditions:}

1990: The LTTE began forcibly conscripting labor for digging trenches and building bunkers beginning in September.

1991: The LTTE forcibly recruits labor for digging trenches and building bunkers, and ferrying supplies.

1999: The LTTE began a program of compulsory physical training, including mock military drills, for most of the population of the areas that it controls, including schoolchildren and the aged.

2000: The LTTE began a program of compulsory physical training, including mock military drills, for most of the population of the areas that it controls, including schoolchildren and the aged. (It is widely believed this is done to gain tighter control of the poipulation and to provide a base for recruiting fighters).

2001: The LTTE began a program of compulsory physical training, including mock military drills, for most of the population of the areas that it controls, including schoolchildren and the aged. (It is widely believed this is done to gain tighter control of the poipulation and to provide a base for recruiting fighters).

\section{Brief historical/political overview}

1989: Tensions in the eighties between Sri Lanka's majority Sinhalese and minority Tamil populations lead to armed conflict between government forces and Tamil separatists. A peace 
accord between the governments of India and Sri Lanka was signed. However radicals from both major ethnic groups refused to accept the Accord. In the Sinhalese-majority south, government security forces were pitted against the revolutionary Janatha Vmukthi Peramuna (JVP) attempting to overthrow the Government by terrorist methods. In the Tamil-mjority northeast, the Liberation Tigers of Tamil Eelam (LTTE) waged guerilla war against the Indian Peace-Keeping Force (IPKF), introduced under the Accord, and India's Tamil militant allies. The attacks by the JVP did not stop even after having tried to bring the JVP into political life and legalise the organisation. Thus in 1989 the Government cracked down on the JVP, arrested many suspected members and killed much of the JVP's top leadership. In September a Peace Accord was signed between the LTTE and Indian Forces and Tamil allies. In the same months India and Sri Lanka agreed on the withdrawal of Indian soldiers. The withdrawal started during the year and will be complete by March 31, 1990. In one incident in December withdrawing IPKF soldiers clashed with LTTE rebels. The result was 100 combatants dead and 50 civilians dead. A new Parliament was voted in February. The elections were marred by the killing of hundreds of voters and 14 parliamentary candidates. However the elections were considered largely free and fair. The Prevention of Terrorism Act was in effect throughout the year. There was a rise of anti-JVP vigilante groups in the south. Observers largely agree these groups are manned partly by security personnel operating with the knowledge of the Government. IPKF troops used torture. In the South the JVP used intimidation to recruit unwilling members and to force participation in demonstrations and other activities liable to subject individuals to criminal prosecution. They did this in universities and secondary schools. This resulted in much campus unrest and closure of most schools for the rest of the year. India's Tamil allies forcibly recruit young men to provide manpower for the defense of Tamil-majority areas. A great number of people disappeared.

1990: The IPKF withdrew by March 31. JVP cadres were unable to regroup sufficiantly after much of their leadership was captured or killed. LTTE seized control of the Jaffna Peninsula, while continuing negotiations. The Government ordered the army to take a non-confrontational stand. On June 11 LTTE broke of negotiations and attacked a number of police stations in the east. The human rights situations, which had ameliorated during peace negotiations, seriously deteriorated in the northeast after talks were broken off. In the south the situation ameliorated due to the elimination of the JVP leadership. However vigilante groups continued to operate. The PTA and Emergency Regulations remained in effect. However some provisions were rescinded. A great number of people disappeared.

1991: The conflict with LTTE continued. JVP terrorism ended. Life in the South was largely normal. LTTE operations were largely confined to the north and east. However two bombs in Colombo destroyed the Ministry of Defence and left many civilians dead. Number of incidents was reduced. 710 civilians died in 1991. PTA and ER remained in force,but were partly suspended (except in the northeast) to permit unhindered elections. A great number of people disappeared. Though less than in the previous five years. The Government publicly and privately declared the war in the east and the north is a war against the LTTE and not against the Tamil population, this is believed to have significantly reduced communal violence. The bodies of 300 policemen captured in 1991 were recovered. Local Government elections held in May are considered free and fair.

1992: Peaceful resolution of the conflict was complicated even further. LTTE escalated its attacks on the Muslim and Sinhalese population in an effort to drive the communities out of the Tamil provinces. As a result of this armed Muslim groups masacred innocent civilians. Some 200 people disappeared (attributed largely to security forces), which is a sharp decline of previous years. 650 civilians died of extrajudicial killings or combat related deaths. There seems to an effort to stop human rights abuses by the Government. Attacks on civilians by Government forces appear to be the result of lapses of discipline rather than policy decisions. Members of opposition groups were increasingly harassed.

1993: No mention of torture in the report. On May 1 President Premadasa is assassinated by an LTTE suicide bomber. President Dingiri Banda Wijetunga is chosen by the Parliament to succeed Premadasa. About 70 people disappeared in the first nine months of the year (a significant decline from the previous year). LTTE are also responsible for disappearance, 
however it is not known how many. It is widely believed that the decision to grant the ICRC unhindered access to detention centers, police stations and army camps has played an important role in reducing the number of disappearances. There was a lull in fighting during the first nine months of the year, but the fighting reached new level of intensity in the $4^{\text {th }}$ quarter of the year, as both sides launched major offensives. There were increasing attacks on civilian targets by the Sri Lankan army. Thee was an increased use of curfews and checkpoints by the Army and LTTE which made travel within the country difficult. Especially for young Tamil men, and especially after the killing of the President. After the death of the President, organised harassment of the opposition ceased.

1994: The LTTE was responsible for an undetermined amount of disappearances. In generally free and fair elections the People's Alliance ended the 17 year control of Parliament by the United National Party, and Chandrika Kumaratunga, became Prime Minister. A dialogue was initiated with the LTTE. Security forces committed significantly less human rights abuses than in previous years. The United National Party's candidate for the elections was killed in a suicide attack. Suspects in several extrajudicial killings were prosecuted. In most of the country ER were lifted, this made concealment of extrajudicial killings and disappearances difficult. Travel restrictions were eased, but remained strict for young Tamil men.

1995: The LTTE was responsible for an undetermined amount of disappearances. For the first time rape was used as a weapon of terror._Cessation of hostilities on January 3. The truce was broken when LTTE attacked security forces in April. Governmental forces succeeded in capturing the unofficial capital of the rebels, Jaffna City, after major offensives. During cessation governmental forces committed very few human rights abuses. With the resumption of hostilities the number of abuses increased. The Government moved to correct the worst relapses. The JVP is legalised. Travel restrictions were once more applied more strictly. This affected young Tamil men in their freedom of movement.

1996: The LTTE was responsible for an undetermined amount of disappearances. Children as young as 10 are said to be recruited and placed for 2 to 4 years in special schools that provide them with a mixture of LTTE ideology and formal education. A six month military offensive captured the LTTE heartland of the Jaffna Peninsula in April. The LTTE inflicted a major military defeat on Government forces at a military base in the North killing upwards of 1,500 troops. Intensification of the conflict meant a deterioration in the human rights situation. In April the ER was reimposed nationwide. There was no evidence the ER were used to conceal extrajudial executions or disappearances. However crucial protective safeguards were frequently ignored. Civilian casualties in the renewed fighting were limited, because security forces showed much greater restraint in the use of excessive force. Moreover troops advanced slowly and methodically. Travel restrictions were once more applied more strictly. This affected young Tamil men in their freedom of movement. Local elections were postponed by the President under ER.

1997: The LTTE was responsible for an undetermined amount of disappearances. Children as young as 10 are said to be recruited and placed for 2 to 4 years in special schools that provide them with a mixture of LTTE ideology and formal education. In May the Government forces launched a major new offensive aimed at opening a land route to the Jaffna Peninsula through LTTE controlled territory. The offensive resulted in hundreds killed. The Government generally respected the human rights of its citizens in areas not affected by the conflict. ER was lifted outside of the north and east and Colombo. Violence between supporters of the major political parties worsened and six people including a member of Parliament were killed in violence related to local government electionsin March. Civilian casualties were limited in the first six months of the year, because security forces showed much greater restraint in the use of excessive force. Moreover troops advanced slowly and methodically. Elections in the Jaffna Peninsula were postponed untill January 1998.

1998: The LTTE was responsible for an undetermined amount of disappearances. Children as young as 10 are said to be recruited and placed for 2 to 4 years in special schools that provide them with a mixture of LTTE ideology and formal education. The conflict between LTTE and the Sri Lankan Government has claimed over 55,000 lives so far. The offensive launched in 
May 1997 ended in December and claimed approx. 5,000 combattant deaths on both sides. State of emergency was reimposed nationwide.

1999: The LTTE was responsible for an undetermined amount of disappearances. Children as young as 10 are said to be recruited and placed for 2 to 4 years in special schools that provide them with a mixture of LTTE ideology and formal education. The President scheduled early Presidential elections in December. She won the generally free and fair elections. However the preelection and election period were marred by violence. At least six persons were killed and there was an unsuccessfull assassination attempt on the President by the LTTE. The whole conflict between the government and the LTTE has claimed 60,000 lives so far. The Government gained much territory in a series of offensives. In a counterattack the LTTE regained much of the territory lost in the last two years.More than a thousand combattants were killed in the fighting. Sine April 1995 at least 761 persons have been extrajudicially killed by security forces or have disappeared and are presumed dead.

2000: The LTTE was responsible for an undetermined amount of disappearances. Violence and fraud marked the October parliamentary elections. At least seven persons died in election related violence. The elections resulted in a reduced majority of the PA. The conflict between Government and LTTE claimed 62,000 lives so far. A major offensive on the Jaffna Peninsula left many dead (civilians and combatants). Violent clashes continued during the year. More than 2,000 combattants and more than 100 civilians were killed in incidents related to the conflict. The army was more secretive about missions than in previous years. The publicity given to offensives in the past limited civilian casualties. Tamils are frequently harassed at checkpoints.

2001: The LTTE was responsible for an undetermined amount of disappearances. Parliamentary elections in December were marred by violence, at least 50 deaths, and irregularities (including the refusal to allow 40,000 Tamils to vote). A coaltion lead by the UNP won a majority in Parliament. The conflict has claimed at least 64,000 lives untill now. In April government forces launched a major offensive on the Jaffna Peninsula, this resulted in heavy losses. In July LTTE attacked Colombo's international airport. At year's end the Governmetn and the LTTE had each announced unilateral cease-fires. It is believed as many as 2,000 combattants and 100 civilians were killed in conflict-related incidents. The army was more secretive about missions than in previous years. The publicity given to offensives in the past limited civilian casualties. Tamils are frequently harassed at checkpoints.

2002: The LTTE was responsible for an undetermined amount of civilian disappearances. The Government and LTTE started a historic process of reconciliation in December 2001. This process continued in Norwegian-facilitated talks in Thailand and Norway. The talks were successful and will continue into 2003. As a result of the peace there was sharp reduction in roadblocks and checkpoints around the country, the return of 220,000 internally displaced persons, and the opening of investigations into questionnable actions by security forces. On September 4 the LTTE was legalized.

\footnotetext{
${ }^{1}$ There were allegations of torture.

${ }^{2}$ The LTTE was responsible for the deaths of many rival Tamil politicians. In clashes between the LTTE and the Government more than 1,500 civilians died. In the attacks on seven police stations on June 11 some 600 police officers surrendered. It is widely believed that at least 200 of these police officers were killed by the LTTE. The LTTE also killed a great number of muslims, before telling them to leave within a few days.

${ }^{3}$ There were allegations of torture.

${ }^{4}$ Of Muslims.

${ }^{5}$ Two bombs in Colombo on military targets, but in residential areas caused a number of civilian deaths. 182 civilians were killed in deliberate attacks.

${ }_{7}^{6}$ There were allegations of torture.

7 The LTTE is believed to have committed at least 400 politically motivated killings, most involving indiscriminate attacks on civilians.

${ }^{8}$ There were allegations of torture.

${ }^{9}$ There were less deliberate killings of civilians. However there still were a number of summary executions. Especially of people thought to be aiding the Governemnt forces. There were two high level assassinations: the opposition leader and the President.

${ }^{10}$ High school-age children were sometimes conscripted for work as cooks, messengers, and clerks. There were reliable reports of children being used as forced labor to build fortifications.
} 
${ }^{11}$ Extrajudicial killings were not restricted to Sri Lanka as an LTTE opponent and four other Tamils were killed in Paris. The LTTE also used excessive force, killing an undetermined number of civilians.

${ }^{12}$ Conditions are believed to be poor.

${ }^{13}$ The LTTE reportedly used torture on a routine basis. Because of the secretive nature of the LTTE, virtually no first-hand information is available regarding their use of torture.

${ }^{14}$ High school-age children were sometimes conscripted for work as cooks, messengers, and clerks. There were reliable reports of children being used as forced labor to build fortifications.

${ }^{15}$ A great number of extrajudicial killings were committed. Among which the killing of 42 Sinhalese civilians in a fishing village, 120 sinhalese civilians, a number of political opponents, 29 suspected government spies and 16 persons in suicide bombing attacks. The LTTE also used excessive force, killing an undetermined number of civilians.

${ }^{16}$ Conditions are believed to be poor.

${ }^{17}$ The LTTE reportedly used torture on a routine basis. Because of the secretive nature of the LTTE, virtually no first-hand information is available regarding their use of torture.

${ }^{18}$ High school-age children were sometimes conscripted for work as cooks, messengers, and clerks. There were reliable reports of children being used as forced labor to build fortifications.

${ }^{19}$ LTTE is believed to be using child soldiers. However reports that the LTTE is conscripting children are impossible to verify.

${ }^{20}$ LTTE continued to commit extrajudicial executions. More than 185 people were killd in terrorist bombings. Numerous assassinations of political opponents were committed. Massacres of civilians continued (14 Sinhalese villagers, 11 Sinhalese travelers). Suspected government informants and university professors and members of nonviolent Tamil opposition parties, and human rights monitors continued to be killed.

${ }^{21}$ Conditions are believed to be poor.

${ }^{22}$ The LTTE reportedly used torture on a routine basis. Because of the secretive nature of the LTTE, virtually no first-hand information is available regarding their use of torture.

${ }^{23}$ High school-age children were conscripted for work as cooks, messengers, clerks, and in some case to build fortifications.

${ }^{24}$ LTTE is believed to be using child soldiers. However reports that the LTTE is conscripting children are impossible to verify.

${ }^{25}$ LTTE continued to commit extrajudicial executions. A number of civilians were killed in terrorist attacks. Numerous assassinations of political opponents were committed. Suspected government informants and university professors and members of nonviolent Tamil opposition parties, and human rights monitors continued to be killed. ${ }^{26}$ Conditions are believed to be poor.

${ }^{27}$ The LTTE reportedly used torture on a routine basis. Because of the secretive nature of the LTTE, virtually no first-hand information is available regarding their use of torture.

${ }^{28}$ High school-age children were conscripted for work as cooks, messengers, clerks, and in some case to build fortifications.

${ }^{29}$ There are credible reports the LTTE has warned Muslims displaced from the Mannar area (approx. 50,000 persons) not to return to their homes untill the war is over.

${ }^{30}$ Extrajudicial executions were regular: terrorist attacks, assassinations, attacks on government installations and killings of suspected government informants, and excessive use of force.

${ }^{31}$ Conditions are poor. Former prisoners report they were being handcuffed and shackled for much of their captivity.

${ }^{32}$ The LTTE reportedly used torture on a routine basis.

${ }_{34}^{33}$ Many captured rebels were under the age of 18.

${ }^{34}$ High school-age children were conscripted for work as cooks, messengers, clerks, and in some case to build fortifications.

${ }^{35}$ The LTTE has expropriated food from internally displaced people, thus exacerbating the plight of such persons in LTTE controlled territory. Malnutrition remained a problem in LTTE-controlled territory.

${ }^{36}$ The LTTE committed extrajudicial executions regularly. These included targeted attacks and bombings. More than hundred civilians were killed in bombings. At least 14 persons were convicted in LTTE self-described courts and sentenced to death. The LTTE acknowledge they rather kill soldiers than take them prisoner. Moreover it seems they also kill their own injured soldiers so they are not made captive.

${ }^{37}$ Prison conditions were poor. Former prisoners report being handcuffed and shackled during much of their detention. The ICRC were permitted to see only a few prisoners.

${ }^{38}$ LTTE reportedly use torture routinely.

${ }^{39}$ High school-age children were conscripted for work as cooks, messengers, clerks, and in some case to build fortifications. The LTTE began a program of compulsory physical training, including mock military drills, for most of the population of the areas that it controls, including schoolchildren and the aged.

${ }^{40}$ There are credible reports the LTTE has warned Muslims displaced from the Mannar area (approx. 55,000 persons) not to return to their homes until the conflict is over.

${ }^{41}$ LTTE expropriates food further exacerbating the plight of such persons in LTTE controlled territory. Malnutrition remained a problem in LTTE controlled territory and other parts of the Vanni region. Malnutrition caused an increase in anemia and a lower birth rate. Malnutrition is caused among others by food shortages. 
${ }^{42}$ At least170 civilians were killed from January to September in LTTE suicide bombings and other attacks outside of the Northern conflict zone. LTTE killed prisoners taken on the battlefield. LTTE uses excessive force in fighting, killing civilians.

${ }^{43}$ Prison conditions were poor. Former prisoners report being handcuffed and shackled during much of their detention. The ICRC were permitted to visit detainees in the Vanni regularly.

${ }^{44}$ LTTE reportedly use torture routinely.

${ }^{45}$ High school-age children were conscripted for work as cooks, messengers, clerks, and in some case to build fortifications. The LTTE began a program of compulsory physical training, including mock military drills, for most of the population of the areas that it controls, including schoolchildren and the aged. It is widely believed this is done to gain tighter control of the poipulation and to provide a base for recruiting fighters.

${ }^{46}$ There are credible reports the LTTE has warned Muslims displaced from the Mannar area (approx. 66,000 persons) not to return to their homes until the conflict is over.

${ }^{47}$ LTTE expropriates food further exacerbating the plight of such persons in LTTE controlled territory. Malnutrition remained a problem in LTTE controlled territory and other parts of the Vanni region. Malnutrition caused an increase in anemia and a lower birth rate. Malnutrition is caused among others by food shortages. However Medecins sand Frontieres found malnutrition to be at about the same level as in war-free South.

${ }^{48}$ It is not known how many extrajudicial executions were committed. LTTE continued to kill civilians outside its territory. LTTE continued to bomb civilian targets. LTTE executed people after sentencing in self-described courts. LTTE sometimes kills its own troops when they are injured in order to avoid capture. LTTE kills soldiers rather than make them prisoner. Many civilians were killed (more than 100).

${ }^{49}$ Prison conditions were poor. Former prisoners report being handcuffed and shackled during much of their detention. The ICRC were permitted to visit detainees in the Vanni regularly.

${ }^{50}$ LTTE reportedly use torture routinely.

${ }^{51}$ High school-age children were conscripted for work as cooks, messengers, clerks, and in some case to build fortifications. The LTTE began a program of compulsory physical training, including mock military drills, for most of the population of the areas that it controls, including schoolchildren and the aged. It is widely believed this is done to gain tighter control of the poipulation and to provide a base for recruiting fighters.

${ }^{52}$ There are credible reports the LTTE has warned Muslims displaced from the Mannar area (approx. 66,000 persons) not to return to their homes until the conflict is over.

53 LTTE expropriates food further exacerbating the plight of such persons in LTTE controlled territory. Malnutrition remained a problem in LTTE controlled territory and other parts of the Vanni region. Malnutrition caused an increase in anemia and a lower birth rate. Malnutrition is caused among others by food shortages. However Medecins sand Frontieres found malnutrition to be at about the same level as in war-free South.

${ }^{54}$ There were unconfirmed reports that the LTTE committed unlawful killings. However the exact number of these killings is impossible to ascertain. Some observers believe that the amount of killings was reduced drastically.

${ }^{55}$ Prison conditions were poor. Former prisoners report being handcuffed and shackled during much of their detention. The ICRC were permitted to visit detainees.

${ }^{56}$ LTTE reportedly used torture on a routine basis.

${ }^{57}$ High school-age children were conscripted for work as cooks, messengers, clerks, and in some case to build fortifications. The LTTE began a program of compulsory physical training, including mock military drills, for most of the population of the areas that it controls, including schoolchildren and the aged. It is widely believed this is done to gain tighter control of the poipulation and to provide a base for recruiting fighters.

${ }^{58}$ LTTE expropriates food further exacerbating the plight of such persons in LTTE controlled territory. Malnutrition remained a problem in LTTE controlled territory and other parts of the Vanni region. Malnutrition caused an increase in anemia and a lower birth rate. Malnutrition is caused among others by food shortages. However Medecins sand Frontieres found malnutrition to be at about the same level as in war-free South. 


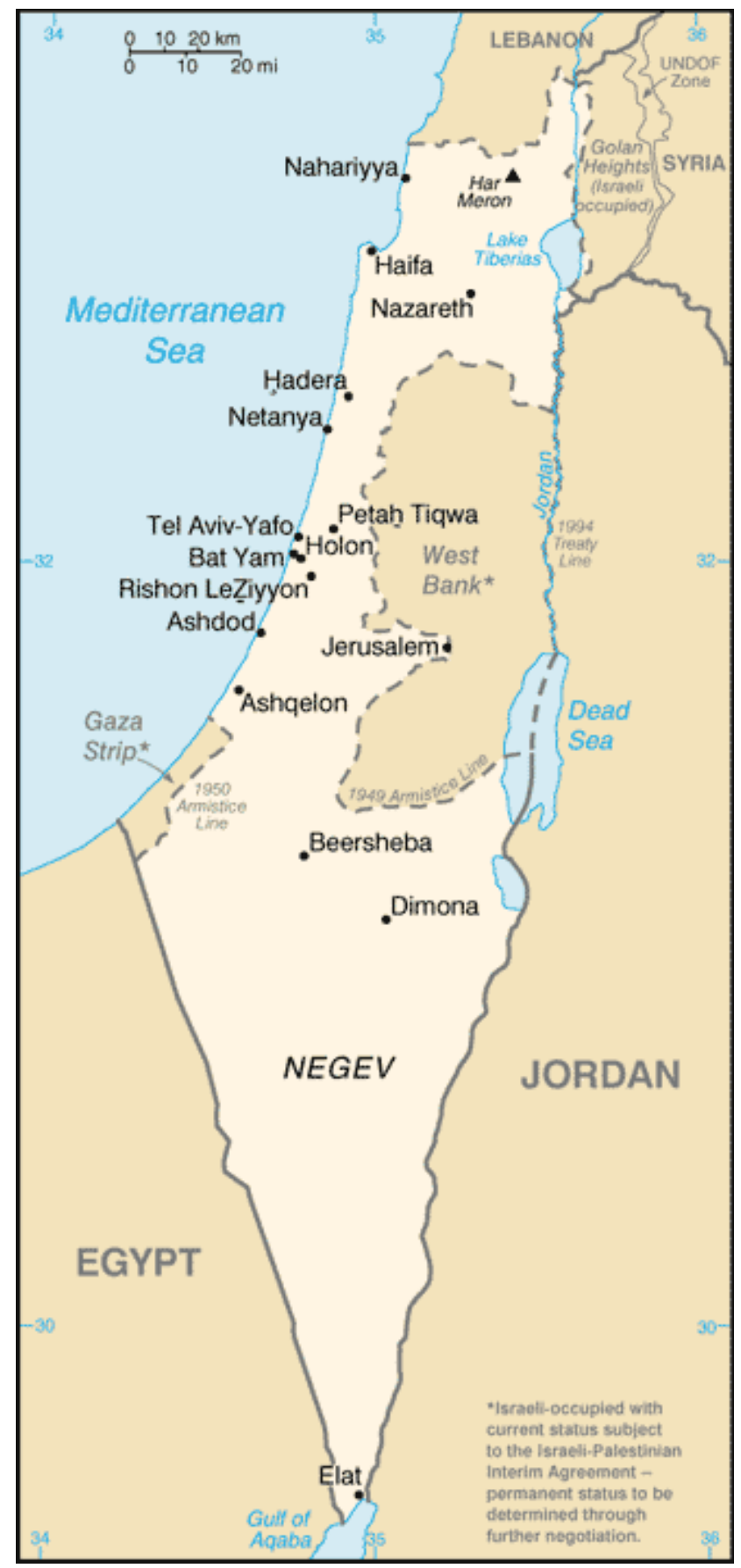

$\underline{\text { Israel }^{1}}$

(Population: 6,116,533, without settlers in PA and OT)

\begin{tabular}{|c|c|c|c|c|}
\hline & $\mathbf{1 9 8 9}$ & $\mathbf{1 9 9 0}$ & $\mathbf{1 9 9 1}$ & $\mathbf{1 9 9 2}$ \\
\hline $\begin{array}{c}\text { Political } \\
\text { Terrorscale }\end{array}$ & $3 / 2$ & $2 / 2$ & $2 / 2$ & $9 / 2$ \\
\hline $\begin{array}{c}\text { Conflict Level } \\
\text { Freedom } \\
\text { House }\end{array}$ & $\begin{array}{c}\text { Violent political } \\
\text { conflict }\end{array}$ & $\begin{array}{c}\text { Violent political } \\
\text { conflict }\end{array}$ & $\begin{array}{c}\text { Violent political } \\
\text { conflict }\end{array}$ & $\begin{array}{c}\text { Violent political } \\
\text { conflict }\end{array}$ \\
\hline $\begin{array}{c}\text { U.S. State } \\
\text { Department }\end{array}$ & $2 / 2 / \mathrm{F}$ & $2 / 2 / \mathrm{F}$ & $2 / 2 / \mathrm{F}$ & $2 / 2 / \mathrm{F}$ \\
\hline
\end{tabular}




\begin{tabular}{|c|c|c|c|c|}
\hline $\begin{array}{c}\text { Political } \\
\text { Terrorscale }\end{array}$ & $\mathbf{1 9 9 3}$ & $\mathbf{1 9 9 4}$ & $\mathbf{1 9 9 5}$ & $\mathbf{1 9 9 6}$ \\
\hline Conflict Level & $\begin{array}{c}\text { Violent political } \\
\text { conflict }\end{array}$ & $\begin{array}{c}\text { Violent political } \\
\text { conflict }\end{array}$ & $\begin{array}{c}\text { Violent political } \\
\text { conflict }\end{array}$ & $\begin{array}{c}\text { Violent political } \\
\text { conflict } / \text { low } \\
\text { intensity conflict } \\
\text { (Israel/Lebanon; } 150 \\
\text { civilians dead) }\end{array}$ \\
\hline $\begin{array}{c}\text { Freedom } \\
\text { House }\end{array}$ & $1 / 2 / \mathrm{F}$ & $1 / 3 / \mathrm{F}$ & $1 / 3 / \mathrm{F}$ & $1 / 3 / \mathrm{F}$ \\
\hline $\begin{array}{c}\text { U.S. State } \\
\text { Department }\end{array}$ & $\mathrm{p}^{12}, \mathrm{AE}^{13}, \mathrm{PC}^{14}, \mathrm{DH}^{15}$ & $\mathrm{p}^{16}, \mathrm{AE}^{17}, \mathrm{DH}^{18}$ & $\begin{array}{c}\mathrm{e}^{19}, \mathrm{p}^{20}, \mathrm{t}^{21}, \mathrm{AE}^{22}, \\
\mathrm{CA}^{23}, \mathrm{CL}^{24}, \mathrm{PC}^{25}, \\
\mathrm{DH}^{26}\end{array}$ & $\begin{array}{c}\mathrm{p}^{27}, \mathrm{t}^{28}, \mathrm{AE}^{29}, \mathrm{CA}^{30} \\
\mathrm{CL}^{31}, \mathrm{CP}^{32}, \mathrm{PC}^{33}, \\
\mathrm{DH}^{34}, \mathrm{FE}^{35}\end{array}$ \\
\hline
\end{tabular}

\begin{tabular}{|c|c|c|c|c|}
\hline & 1997 & 1998 & 1999 & 2000 \\
\hline $\begin{array}{c}\text { Political } \\
\text { Terrorscale }\end{array}$ & 2 & 2 & & 4 \\
\hline Conflict Level & $\begin{array}{l}2 \text { Violent political } \\
\text { conflicts } \\
\text { (Lebanon/Israel, less } \\
\text { victims than previous } \\
\text { year) }\end{array}$ & $\begin{array}{l}2 \text { Violent political } \\
\text { conflicts } \\
\text { (Lebanon/Israel, } 79 \\
\text { casualties) }\end{array}$ & $\begin{array}{l}2 \text { Violent political } \\
\text { conflicts } \\
\text { (Israel/Lebanon, } 92 \\
\text { casualties) }\end{array}$ & $\begin{array}{l}2 \text { violent political } \\
\text { conflicts } \\
\text { (Israel/Lebanon, } \\
\text { approx. } 50 \\
\text { casualties) } \\
\text { (36 }\end{array}$ \\
\hline $\begin{array}{c}\text { Freedom } \\
\text { House }\end{array}$ & $1 / 3 / F$ & $1 / 3 / F$ & $1 / 2 / F$ & $1 / 3 / F$ \\
\hline $\begin{array}{c}\text { U.S. State } \\
\text { Department }\end{array}$ & $\begin{array}{c}\mathrm{e}^{37}, \mathrm{p}^{38}, \mathrm{~T}^{39}, \mathrm{PC}^{40} \\
\mathrm{AE}^{41}, \mathrm{CA}^{42}, \mathrm{CL}^{43} \\
\mathrm{CP}^{44}, \mathrm{DH}^{45}\end{array}$ & $\begin{array}{l}\mathrm{e}^{46}, \mathrm{p}^{47}, \mathrm{t}^{48}, \mathrm{AE}^{49} \\
\mathrm{CA}^{50}, \mathrm{CL}^{51}, \mathrm{CP}^{52}, \\
\mathrm{PC}^{53}, \mathrm{DH}^{54}, \mathrm{TP}^{55}\end{array}$ & $\begin{array}{c}\left(\mathrm{e}^{56}{ }^{56} \mathrm{p}^{57}, \mathrm{t}^{58}, \mathrm{AE}^{59},\right. \\
\mathrm{CA}^{60}{ }^{60}, \mathrm{CL}^{61}, \mathrm{CP}^{62}, \\
\mathrm{PC}^{63}, \mathrm{DH}^{64}, \mathrm{D}^{65}\end{array}$ & $\begin{array}{c}\mathrm{E}^{66}, \mathrm{p}^{67}, \mathrm{t}^{68}, \mathrm{AE}^{69}, \\
\mathrm{CA}^{70}, \mathrm{CL}^{71}, \mathrm{CP}^{72} \\
\mathrm{PC}^{73}, \mathrm{DH}^{74}\end{array}$ \\
\hline
\end{tabular}

\begin{tabular}{|c|c|c|}
\hline $\begin{array}{c}\text { Political } \\
\text { Terrorscale }\end{array}$ & $\mathbf{2 0 0 1}$ & $\mathbf{2 0 0 2}$ \\
\hline Conflict Level & $\begin{array}{c}\text { Low-intensity } \\
\text { conflict/Violent } \\
\text { political conflict } \\
\text { (border } \\
\text { Israel/Lebanon) }\end{array}$ & $\begin{array}{c}\text { Low-intensity } \\
\text { conflict/Violent } \\
\text { political conflict } \\
\text { (border } \\
\text { Israel/Lebanon) }\end{array}$ \\
\hline Freedom & $1 / 3 / \mathrm{F}$ & $1 / 3 / \mathrm{F}$ \\
\hline $\begin{array}{c}\text { U.S.S. State } \\
\text { Department }\end{array}$ & $\begin{array}{c}\mathrm{p}^{75}, \mathrm{~T}^{76}, \mathrm{AE}^{77}, \mathrm{CA}^{78}, \\
\mathrm{CL}^{79}, \mathrm{CP}^{80}, \mathrm{PC}^{81}, \\
\mathrm{DH}^{82}\end{array}$ & $\begin{array}{c}\mathrm{p}^{83},\left(\mathrm{P}^{84}, \mathrm{~T}^{85}, \mathrm{AE}^{86},\right. \\
\mathrm{CA}^{87}, \mathrm{CL}^{88}, \mathrm{CP}^{89}, \\
\mathrm{PC}^{90}, \mathrm{DH}^{91}, \mathrm{D}^{92}\end{array}$ \\
\hline
\end{tabular}




\section{Working conditions:}

1989: Nonresident Palestinian workers suffer from inequalities with respect to working conditions. Access to work can be denied to Palestinians.

1990: Nonresident Palestinian workers suffer from inequalities with respect to working conditions. Access to work can be denied to Palestinians.

1993: There is no legal safeguard against being fired when refusing to do hazardous work.

1994: There is no legal safeguard against being fired when refusing to do hazardous work.

1995: There is no legal safeguard against being fired when refusing to do hazardous work.

1996: Civil rights groups charge that unscrupulous employers often take advantage of illegal worker's lack of status to hold them in conditions amounting to involuntary servitude. There is no legal safeguard against being fired when refusing to do hazardous work.

1997: Civil rights groups charge that unscrupulous employers often take advantage of illegal worker's lack of status to hold them in conditions amounting to involuntary servitude. There is no legal safeguard against being fired when refusing to do hazardous work.

1998: Civil rights groups charge that unscrupulous employers often take advantage of illegal worker's lack of status to hold them in conditions amounting to involuntary servitude. There is no legal safeguard against being fired when refusing to do hazardous work.

1999: Civil rights groups charge that unscrupulous employers often take advantage of illegal worker's lack of status to hold them in conditions amounting to involuntary servitude. There is no legal safeguard against being fired when refusing to do hazardous work.

2000: Civil rights groups charge that unscrupulous employers often take advantage of illegal worker's lack of status to hold them in conditions amounting to involuntary servitude. There is no legal safeguard against being fired when refusing to do hazardous work.

2001: Civil rights groups charge that unscrupulous employers often take advantage of illegal worker's lack of status to hold them in conditions amounting to involuntary servitude. There is no legal safeguard against being fired when refusing to do hazardous work.

2002: Civil rights groups charge that unscrupulous employers often take advantage of illegal worker's lack of status to hold them in conditions amounting to involuntary servitude. There is no legal safeguard against being fired when refusing to do hazardous work. Some foreign workers were lured into working in Israel, paying up to $\$ 10.000$.

\section{Brief historical/political overview}

1989: 20 people were killed by Palestinians within pre-1967 Israel and five Palestinians were killed within Israel by private citizens in what can be considered retaliation actions.

1990: There were a few separate incidents in which Israelis and Palestinians were killed (the report mentions 8 Palestinians killed by Israelis and 8 Israelis killed by Palestinians). Following one incident in which seven palestinians were killed there were seven separate incidents in which Israelis were killed by knive by Palestinians. There were some leaflets distributed to announce the beginning of "the intifada of the knives". However the incidents do not appear to be part of a pattern.

1991: 11 Israelis were killed by Palestinians. The murders were linked to Arab nationalist motivations. During the Gulf War there were more restrictions on freedom of press. Arab language publications are more closely scrutinised than there Hebrew equivalents. It is generally asserted that Arab municipalities are underfunded by the Government. Madrid Conference sets peace process in motion.

1992: 13 Israelis were killed by Arabs. The murders were politically motivated. The Fundamental Human Rights Bill, "intended to enshrine the principle of equality before the law and prohibit discrimination on the basis of religion, nationality, race, or place of national origin, is currently being discussed by the Ministerial Committee on Legislation and the Knesset Committee of Constitution, Law and Justice." 
1993: Historical Declaration of Principles is signed with the PLO.At least sixteen Israelis are killed by Arabs.

1994: 52 Israelis were killed by Palestinians inside Israel.

1995: The peace process continued as an agreement was signed on the redeployment of IDF from Palestinian areas in the West Bank, the further transfer of certain powers and responsibilities to the Palestinians, and Palestinian elections. The agreement also calls for the release of certain Palestinian prisoners. Prime Minister Yitzhak Rabin is killed on November 4. During the year 39 Israelis were killed by suicide bombers, more than 250 people were injured. 1996: Benjamin Netanyahu was elected Prime Minister on May 29. A number of Israelis were killed by suicide attackers. Fighting along the Lebanese border after the launching by Hizballah of rockets from Southern Lebanon resulted in 150 civilian deaths and hundreds of wounded civilians on the Lebanese side and dozens of wounded civilians in Israel.

1997: 24 people were killed in suicide attacks. The attacks happened after the Hebron agreement was broken by both sides. Negotiations on Interim Agreement implementation were broken off and did not resume at year's end. The cycle of violence on the Lebanese border continued. However after an understanding between both sides not to launch attacks on civilian areas on April 26 the number of casualties dropped. The legal system often imposes stiffer penalties on Christian, Druze and Arab persons than on Jews.

1998: Wye River Memorandum is signed by th PA and Israel calling for the continuation of the peace process. 8 Israelis were killed and over 100 were wounded in terrorist attacks. Government attempted to seize Israeli Arab land. This sparked violent demonstrations leading to close to 100 arrests and 90 injuries, including 25 injured police officers. In December the Wye River Agreement is frozen by Prime Minister Benjamin Netanyahu's Government. The legal system often imposes stiffer penalties on Christian, Druze and Arab persons than on Jews. 1999: In May the new Prime Minister Ehud Barak took office. The report mentions for the first time that the judiciary has in the past frequently acquiesced with the Government's position (however in this year it has ruled against the Government in some major security-related cases. New Government signs new memorandum laying out a new comprehensive roadmap. One Israeli was killed and over 52 injured in terrorist attacks. The legal system often imposes stiffer penalties on Christian, Druze and Arab persons than on Jews.

2000: On December 9, following the breakdown of his coalition, Barak resigned as Prime Minister. Prime ministerial electios were scheduled to be held on February 6, 2001. Intensive work-level talks were held between March and June by the PLO and the Israeli Government and they met at Camp David in July. No agreement was reached. Since 1897 the Jewish National Fund (JNF) purchases and manages land for the Jewish people. They own $8 \%$ of the country's land area (including a considerable amount transferred directly from the Government) and they manage another $8 \%$ on behalf of the Government. In March the High Court of Justice ruled that the Government's use of the JNF to develop public land was disciminatory, since the JNF's statute prohibits the sale or lease of land to non-jews. The Government's human rights record worsened late in the year regarding its treatment of nonjewish citizens. In October there was an outbreak of violence in the North of the country. Police killed 13 arab citizens, injuring over 300, in demonstrations. There were credible reports that police failed to protect Arab lives and property in several incidents in which Jewish citizens attacked the homes of Arab citizens. One of the main factors contributing to the violence was the lack of tangible steps taken to ameliorate the situation for non-jewish citizens in the country. In early October there were many instances of societal violence between Arab and Jewish citizens. This coincided with violent events in the country. On event that sparked the violence was the visit of the opposition leader Ariel Sharon to the Temple Mount in Jerusalem on September 29. Violence in the Occupied Territories coincided with violence in Israel. 22 Israelis died and 244 were injured in terrorist attacks carried out by Palestinian groups or individuals in Israel and the occupied territories. The legal system often imposes stiffer penalties on Christian, Druze and Arab persons than on Jews.

2001: In February Likud Party leader Ariel Sharon is elected as Prime Minister. Sharon took office in March as the head of a broad "unity" government. With thonset of the "Al-Aqsa Intifada" in September 2000, there was a dramatic escalation in the level of violence directed 
against Israelis. The number of terrorist incidents, and Israeli casualties due to such attacks, rose sharply during the year compared with the previous year. Nearly 2000 terrorist attacks took place during the year. More than 200 israelis were killed and over 1500 injured. The legal system often imposes more severe punishments on Arab citizens than Jewish citizens.

2002: On November 5 labour withdrew from the Government and Prime Minister Sharon announced he was unable to form a coalition and asked the President to dissolve the Knesset and call for new elections. New elections are scheduled for January 28, 2003. During the year there were efforts from the US, Russian Federation, Eu and UN to come to a roadmap with a two-state vision. There were nearly 226 terror attacks. During the year 469 Israelis were killed and over 2,498 injured, which is an increase from 2001. The legal system often imposes more severe punishments on Arab citizens than Jewish citizens. Journalists claim they were restricted in their freedom of movement whenever there was violent unrest.

\footnotetext{
${ }^{1}$ This table only deals with Israel and does not deal with the Occupied Territories or the Palestine Authority.

${ }^{2}$ Israeli Arabs have not attained the same quality of education as Israeli Jews.

${ }^{3}$ Israeli arabs have not attained the same quality of housing as Israeli Jews. Israeli Druze and circassian community have had less access to social and economic benefits as housing and new-household subsidies (primarily because they do not participate in the military draft).

${ }^{4}$ Israeli Arabs have not attained the same quality of education as Israeli Jews.

${ }^{5}$ Israeli arabs have not attained the same quality of housing as Israeli Jews. Israeli Druze and circassian community have had less access to social and economic benefits as housing and new-household subsidies (primarily because they do not participate in the military draft).

${ }^{6}$ Israeli Arabs have not attained the same quality of education as Israeli Jews.

7 Israeli arabs have not attained the same quality of housing as Israeli Jews. Israeli Druze and circassian community have had less access to social and economic benefits as housing and new-household subsidies (primarily because they do not participate in the military draft).

${ }^{8}$ Israeli Arab residents of the village of Ramyeh were ordered to leave their property. They got a compensation well below the market price of their property. They were still appealing the decision by year's end.

${ }^{9}$ Israeli Arabs have not attained the same quality of education as Israeli Jews. A 1992 report by the Comptroller criticized governemnt policy which have resulted in the inequality between educational standards of Arabs and that of Jews.

${ }^{10}$ Israeli arabs have not attained the same quality of housing as Israeli Jews. Israeli Druze and circassian community have had less access to social and economic benefits as housing and new-household subsidies (primarily because they do not participate in the military draft).

${ }^{11}$ The residents of Ramyah were still subject to eviction orders.

12 Police detention centers have become de facto prisons, due to chronic overcrowding. Inmates at these facilities are accorded less rights than inmates in regular IPS facilities.Prison conditions are harsher for security detainees. Prisons run by the IDF do not meet international minimum standards. Certain camps use unheated tents even in severe weather conditions.

${ }^{13}$ Israeli Arabs do not have the same quality of education as Israeli Jews.

${ }^{14}$ In IDF detention camps minors are held with adults.

${ }^{15}$ Israeli Arabs do not enjoy the same standard housing as Jews.

${ }^{16}$ Police detention centers have become de facto prisons, due to chronic overcrowding. Inmates at these facilities are accorded less rights than inmates in regular IPS facilities.Prison conditions are harsher for security detainees. Overcrowding is the most severe problem. Though the number of detainees dropped sharply, prisons run by the IDF do not meet international minimum standards. Certain camps use unheated tents even in severe weather conditions.

${ }^{17}$ Israeli Arabs do not have the same quality of education as Israeli Jews.

${ }^{18}$ Israeli Arabs do not enjoy the same standard housing as Jews.

${ }^{19}$ At least six Palestinians died while in custody of Israeli authorities.

${ }^{20}$ Security detainees are subject to a different regime from 'regular' inmates, even at IPS (Israeli Prison Service) facilities. At holding facilities overcrowding is a problem. In Jerusalem's Russian Compound there is overcrowding and dilapidation. Conditions at police detention facilities can fall below minimum international standards. These facilities have often become de facto jails. Inmates of these facilities do not have the same rights as those in IPS facilities. IDF administered detention camps are limited to Palestinian security detainees. In many cases these camps did not meet minimum international standards. Many camps house inmates in unheated tents in severe weather conditions, or in overcrowded and poorly ventilated buildings. In addition visits have been prevented are restricted.

${ }^{21}$ Shin Beth use the practice of violent shaking. It is not clear from the report whether the practice is widespread. However at one prisoner died of this practice in April. In late December, in response to a detainee's petition, the Supreme Court issued an injunction against the use of physical force in interrogation.

${ }^{22}$ Children's rights groups express particular concern over the lack of special education facilities for Bedouin children. Israeli Arabs are not provided with the same quality of education as Jews.
} 
${ }^{23}$ The increasing number of reported cases of child abuse is probably due to increased awareness and not necessarily part of a pattern of abuse.

${ }^{24}$ Primarily among Israeli Arabs and new Jewish immigrants.

${ }^{25}$ Civil rights groups have expressed concern about the conditions in which minors are held. They have recommended the building of a separate detention facility. Although children are kept separate from adults there have been some cases of sexual molestation.

${ }^{26}$ Israeli Arabs do not enjoy the same standard housing as Jews.

${ }^{27}$ Conditions at some national police detention facilities can fall below minimum international standards. Conditions are worse for security detainees at police facilities and in IPS (Israeli Prison Service) prisons. After a report by a local NGO the government has vowed to improve conditions. They build a new prison closed a very old one and made some minor improvements in others. However dilpidation and overcrowding are still problems, this is aggravated by the closure of IDF detention facilities in the occupied territories. New legislation on the minimum standards for detainees will be enacted in 1997. IDF detention facilities also have poor conditions. However the centre that was most criticised was closed down and some improvements were made to existing detention centres.

${ }^{28}$ In so-called "ticking bomb" cases security officers can be authorised by the head of Shin Beth to use "moderate physical and psychological pressure" in interrogating Palestinian detainees. This was done in several cases and include the practice of violent shaking (which is a torture technique). The technique was repeatedly challenged before the courts. However the only restriction that has to be applied in using force is that there needs to be a showable cause to do it.

${ }^{29}$ Children of foreign workers (many of them illegal workers) have no access to education. Israeli Arabs still do not have the same quality education as Jews. Schools in Arab communities are dilapidated and overcrwded, lack special education services and counselors, have poor libraries and have no sports facilities. The public school curriculum stresses Israel's Jewish culture and heritage.

${ }^{30}$ The increasing number of reported cases of child abuse is probably due to increased awareness and not necessarily part of a pattern of abuse.

${ }^{31}$ Primarily among Israeli Arabs and new Jewish immigrants.

${ }^{32}$ There are several hundred child prostitutes in the country.

${ }^{33}$ Separate sections of holding facilities set aside for the detention of children were overcrowded, had poor physical conditions, lack of social workers and denial of visits by parents. Some Israeli minors held in criminal cases and juveniles were held among Palestinian detainees.

${ }_{35}^{34}$ Israeli Arabs do not enjoy the same standard housing as Jews.

${ }^{35}$ The conflict on the Lebanese border caused between 200,000 and 300,000 lebanese and between 20,000 and 30,000 Israelis to flee.

${ }^{36}$ In May Israeli forces withdrew from Southern Lebanon. Most casualties occurred prior to the withdrawal.

${ }^{37}$ One Palestinian was beaten to death while in Government custody.

${ }^{38}$ Conditions at some national police detention facilities can fall below minimum international standards. Conditions are worse for security detainees at police facilities and in IPS (Israeli Prison Service) prisons. After a report by a local NGO the government has vowed to improve conditions. They build a new prison closed a very old one and made some minor improvements in others. However dilpidation and overcrowding are still problems, this is aggravated by the closure of IDF detention facilities in the occupied territories. New legislation on the minimum standards for detainees will be enacted in 1997. IDF detention facilities also have poor conditions. However the centre that was most criticised was closed down and some improvements were made to existing detention centres. The conditions at the IDF Detention camp, the Russian Compound, have been very much criticised and High Court of Justice President Aharon Barak described conditions as "not fit to serve as lock-up".

${ }^{39}$ Security forces are authorised to apply "moderate physical and psycholoigical pressure" while interrogation detainees. These practices often led to excesses. There weresome 46 cases brought to the High Court almost all calling for a halt to the torture. It is believed many cases of torture are not brought to theCourt.

${ }^{40}$ Separate sections of holding facilities set aside for the detention of children were overcrowded, had poor physical conditions, lack of social workers and denial of visits by parents. Some Israeli minors held in criminal cases and juveniles were held among Palestinian detainees.

${ }^{41}$ Children of foreign workers (many of them illegal workers) have no access to education. Israeli Arabs still do not have the same quality education as Jews. Schools in Arab communities are dilapidated and overcrwded, lack special education services and counselors, have poor libraries and have no sports facilities. The public school curriculum stresses Israel's Jewish culture and heritage. Israeli-Arab students are not eligible to participate in a special education program to provide academic assistance to students from disadvantaged backgrounds. A High Court special committee is studying the problem.

${ }^{42}$ The increasing number of reported cases of child abuse is probably due to increased awareness and not necessarily part of a pattern of abuse.

${ }^{43}$ Primarily among Israeli Arabs and new Jewish immigrants.

${ }^{44}$ There are several hundred child prostitutes in the country.

${ }^{45}$ Israeli Arabs do not enjoy the same standard housing as Jews.

${ }^{46}$ Amal faction leader Hussam Al Amin was killed by Israeli forces in attack in Lebanon. Two Palestinian "security" detainees died in custody, one from an alleged suicide attempt. 
${ }^{47}$ Conditions at some national police detention facilities can fall below minimum international standards. Conditions are worse for security detainees at police facilities and in IPS (Israeli Prison Service) prisons. Dilpidation and overcrowding are still problems, this is aggravated by the closure of IDF detention facilities in the occupied territories. New legislation on the minimum standards for detainees was enacted in 1997, but has had very little impact so far. IDF detention facilities also have poor conditions. The conditions at the IDF Detention camp, the Russian Compound, have been very much criticised and High Court of Justice President Aharon Barak described conditions as "not fit to serve as lock-up". Since then minor improvements have been made.

${ }^{48}$ The report states that there were some cases of torture. However the report also states that the use of "moderate physical and psychological pressure" is permitted. This has often led to excesses. The moderate psychological and physical pressure can amount to torture.

${ }^{49}$ Children of foreign workers (many of them illegal workers) have no access to education. Israeli Arabs still do not have the same quality education as Jews. Schools in Arab communities are dilapidated and overcrwded, lack special education services and counselors, have poor libraries and have no sports facilities. The public school curriculum stresses Israel's Jewish culture and heritage. Israeli-Arab students are not eligible to participate in a special education program to provide academic assistance to students from disadvantaged backgrounds. A High Court special committee is still studying the problem.

${ }^{50}$ According to press reports an estimated 60.000 women and girls were sexually assaulted or abused, an estimated $60 \%$ of them were girls under the age of 18 . The increasing number of reported cases of child abuse is probably due to increased awareness and not necessarily part of a pattern of abuse.

${ }_{51}^{51}$ Primarily among Israeli Arabs and new Jewish immigrants.

${ }^{52}$ There are several hundred child prostitutes in the country. The Governemnt is currently trying to evaluate the problem.

${ }_{53}$ Separate sections of holding facilities set aside for the detention of children were overcrowded, had poor physical conditions, lack of social workers and denial of visits by parents. Some Israeli minors held in criminal cases and juveniles were held among Palestinian detainees.

${ }^{54}$ Israeli Arabs do not enjoy the same standard housing as Jews.

${ }^{55}$ Trafficking in women and girls has become a significant problem in recent years.

${ }^{56}$ One Palestinian died in custody. Alledgedly he had a heart condition which was worsened by poor prison conditions.

${ }^{57}$ Conditions at some national police detention facilities (which become de facto prisons) can fall below minimum international standards. Conditions are worse for security detainees at police facilities and in IPS (Israeli Prison Service) prisons. Dilpidation and overcrowding are still problems, this is aggravated by the closure of IDF detention facilities in the occupied territories. New legislation on the minimum standards for detainees was enacted in 1997. The Government took steps towards implementing the legislation, however serious problems remain. IDF detention facilities also have poor conditions. The conditions at the IDF Detention camp, the Russian Compound, have been very much criticised and High Court of Justice President Aharon Barak described conditions as "not fit to serve as lock-up". Since 1998 conditions have improved somewhat.

${ }^{58}$ There still were some cases of torture. However a variety of abusive practices, such as violent shaking, painful shackling in contorted positions, sleep deprivations for extended periods of time and prolonged exposure to extreme temperatures, was prohibited by the High Court. There were no cases of such abuse after the ruling. The High Court did leave open the possibility that such practices could be acceptable if authorized by new legislation.

${ }^{59}$ Children of foreign workers (many of them illegal workers) have no access to education. Israeli Arabs still do not have the same quality education as Jews. Schools in Arab communities are dilapidated and overcrwded, lack special education services and counselors, have poor libraries and have no sports facilities. The public school curriculum stresses Israel's Jewish culture and heritage. Israeli-Arab students are not eligible to participate in a special education program to provide academic assistance to students from disadvantaged backgrounds. A High Court special committee is still studying the problem.

${ }^{60}$ The increasing number of reported cases of child abuse is probably due to increased awareness and not necessarily part of a pattern of abuse.

${ }^{61}$ Primarily among Israeli Arabs and new Jewish immigrants.

${ }^{62}$ There are several hundred child prostitutes in the country. The Governemnt is currently trying to evaluate the problem.

${ }^{63}$ Separate sections of holding facilities set aside for the detention of children were overcrowded, had poor physical conditions, lack of social workers and denial of visits by parents. Some Israeli minors held in criminal cases and juveniles were held among Palestinian detainees.

${ }^{64}$ Israeli Arabs do not enjoy the same standard housing as Jews.

${ }^{65}$ At a demonstration against the destruction of an Israeli-Arab owned house there was use of excessive force.

${ }^{66} 13$ Arab citizens were killed when police used excessive force to disperse demonstrations. Moreover coinciding with violence in Israel 3 person were killed when police used excessive force in dispersing demonstration along the Israeli-Lebanese border. And 2 Arab citizens were killed when they tried to defend their property against an attack by Jewish citizens. It is not clear whether they were killed by police or by jews. In any case the police failed to protect the Arab citizens.

${ }^{67}$ Conditions at some national police detention facilities (which become de facto prisons)are poor. Conditions are worse for security detainees at police facilities and in IPS (Israeli Prison Service) prisons. Dilpidation and overcrowding are still problems, this is aggravated by the closure of IDF detention facilities in the occupied 
territories. New legislation on the minimum standards for detainees was enacted in 1997. The Government took steps significant towards implementing the legislation, however serious problems remain. IDF detention facilities also have poor conditions. The conditions at the IDF Detention camp, the Russian Compound, have been very much criticised and High Court of Justice President Aharon Barak described conditions as "not fit to serve as lockup". Since 1998 conditions have improved somewhat. Another problem is that of physical abse against Palestinian detainees. In May Palestinian detainees throughout the country began a hunger strike to protest prison conditions and their further incarceration (many palestinians are held without charge). The Government agreed to remove the prisoners from solitary confinement and to allow family visits.

${ }^{68}$ Since the landmark High Court 1999 decision NGO's have been unable to substantiate sporadic allegations of torture.

${ }^{69}$ Children of foreign workers (many of them illegal workers) have no access to education. Israeli Arabs still do not have the same quality education as Jews. Schools in Arab communities are dilapidated and overcrwded, lack special education services and counselors, have poor libraries and have no sports facilities. The public school curriculum stresses Israel's Jewish culture and heritage. Israeli-Arab students are not eligible to participate in a special education program to provide academic assistance to students from disadvantaged backgrounds. A commission on that examined the implementation of the Special Education Law came with recommendations that were not taken over by the government by year's end. A study revealed only $54 \%$ of Arab students finish high school compared with $89 \%$ of Jewish students.

${ }^{70}$ Women's organisations estimate the number of women and girls sexually assaulted is at 2800 (1200 were victim of incest), an estimated $44 \%$ of them were girls under the age of 18 . The increasing number of reported cases of child abuse is probably due to increased awareness and not necessarily part of a pattern of abuse.

${ }_{72}^{71}$ Primarily among Israeli Arabs and new Jewish immigrants.

${ }^{72}$ There are several hundred child prostitutes in the country. The Governemnt is currently trying to evaluate the problem.

${ }^{73}$ Separate sections of holding facilities set aside for the detention of children were overcrowded, had poor physical conditions, lack of social workers and denial of visits by parents. Some Israeli minors held in criminal cases and juveniles were held among Palestinian detainees. Chilren's rights activists won a court battle to get separate prison facilities built for Arab and Jewish children.

${ }^{74}$ The Government follows a disproportionally restrictive policy in issueing building permits to Arab citizens, resulting in the issuance of proportionally more building demolition orders against Arab-built structures. Also see "Political and Historical overview 2000" for problems related to JNF.

${ }^{75}$ Conditions at some national police detention facilities (which become de facto prisons)are poor. Conditions are worse for security detainees at police facilities and in IPS (Israeli Prison Service) prisons. Dilpidation and overcrowding are still problems, this is aggravated by the closure of IDF detention facilities in the occupied territories. New legislation on the minimum standards for detainees was enacted in 1997. The Government continued to take significant steps towards implementing the legislation, however serious problems remain (such as the care of prisoners with a mental illness). IDF detention facilities also have poor conditions. Following the closure of detention centers in the occupied territories in 1995, all security detainees from the occupied territories are held in Israel. The conditions at the IDF Detention camp, the Russian Compound, have been very much criticised and High Court of Justice President Aharon Barak described conditions as "not fit to serve as lock-up". Since 1998 conditions have improved somewhat. Another problem is that of physical abse against Palestinian detainees. Following the violence in September 2000 there were very limited visitation rights (only somewhat restored after intervention by the ICRC). Also only Jewish and Palestinian lawyers with a Jerusalem identification card were allowed to visit clients.

${ }^{76}$ Despite the 1999 high court decision, HRW, B'Tselem, LAW and the Mandela Institute for Political Prisoners reported a sharp increase in the number of allegations that security forces were using torture.

${ }^{77}$ Children of foreign workers (many of them illegal workers) have no access to education. Israeli Arabs still do not have the same quality education as Jews. Arab children make up approx. $25 \%$ of the public school population. Schools in Arab communities are dilapidated and overcrwded, lack special education services and counselors, have poor libraries and have no sports facilities. The public school curriculum stresses Israel's Jewish culture and heritage. The government allocated $26 \%$ of the school budget for the year for the construction of new classrooms for schools in Arab Communities. Israeli-Arab students are not eligible to participate in a special education program to provide academic assistance to students from disadvantaged backgrounds. The government still has not taken up a special commission's recommendations about this problem. However the government did pledge to equalize special education ressources by 2005. A HRW report confirmed discrimination in education between Arab and Jewish children.

${ }^{78}$ Women's organisations estimate the number of women and girls sexually assaulted is at 2800 (1200 were victim of incest), an estimated $44 \%$ of them were girls under the age of 18 . The increasing number of reported cases of child abuse is probably due to increased awareness and not necessarily part of a pattern of abuse.

${ }^{79}$ Primarily among Israeli Arabs and new Jewish immigrants.

${ }^{80}$ There are several hundred child prostitutes in the country. The Governemnt is currently trying to evaluate the problem.

${ }^{81}$ Separate sections of holding facilities set aside for the detention of children were overcrowded, had poor physical conditions, lack of social workers and denial of visits by parents. Some Israeli minors held in criminal 
cases and juveniles were held among Palestinian detainees. Chilren's rights activists won a court battle to get separate prison facilities built for Arab and Jewish children separate from the adult prison population.

${ }^{82}$ The Government follows a disproportionally restrictive policy in issueing building permits to Arab citizens, resulting in the issuance of proportionally more building demolition orders against Arab-built structures. Also see "Political and Historical overview 2000" for problems related to JNF.

${ }^{83}$ There was a sharp increase in the number of Palestinian detainees. Those held for security reasons were usually held in IDF's Megiddo prison, in IPS facilities and in special sections of police detention centres. They were subjected to a different regime and conditions were poor. Separate sections of holding facilities set aside for the detention of children were overcrowded, had poor physical conditions, lack of social workers and denial of visits by parents. Some Israeli minors held in criminal cases and juveniles were held among Palestinian detainees. Chilren's rights activists won a court battle to get separate prison facilities built for Arab and Jewish children separate from the adult prison population. Problems remained with regard to family visits and access to lawyers. Conditions at some national police detention facilities remained poor. They have become de facto prisons and inmates at these facilities were not afforded the same rights as those in the IPS system. There were no programs to improve prison conditions by year's end.

${ }^{84}$ Conditions at the Russian Compound were extremely poor. It is the first time the report states the conditions are extremely poor. However the exact quote says: "Conditions at the Russian Compound remained extremely poor" (emphasis added).

${ }_{85}^{85}$ There was a reported in increase in allegations of security force torture.

${ }^{86}$ Approx. 25\% of school children are Arab Israelis. Government allocates proportionally less ressources to Arab schools than Jewish schools. Many schools in Arab communities were dilapidated and overcroded, lacked special education services and counselors, had poor libraries, and had no sport facilities. 26 percent of the school budget was allocated to the construction of new classrooms for schools in Arab communities. The public school curriculum stresses Israel's Jewish culture and heritage. Arab students were not eligible to participate in a special education program to provide academic assistance to students from disadvantaged backgrounds.

${ }^{87}$ Women's organisations estimate the number of women and girls sexually assaulted is at 3000 (1000 were victim of incest), an estimated $45 \%$ of them were girls under the age of 18 . The increasing number of reported cases of child abuse is probably due to increased awareness and not necessarily part of a pattern of abuse.

${ }^{88}$ The small number of child workers can be found primarily among Israeli Arabs and new Jewish immigrants.

${ }^{89}$ There are several hundred child prostitutes in the country. The Government is currently trying to evaluate the problem.

${ }^{90}$ Some security detainees were minors. Separate sections of holding facilities set aside for the detention of children were overcrowded, had poor physical conditions, lack of social workers and denial of visits by parents. There were separate prison facilities for Arab and Jewish children separate from the adult prison population. Children of foreign workers (many of them illegal workers) have no access to education.

${ }^{91}$ The Government follows a disproportionally restrictive policy in issueing building permits to Arab citizens.

${ }^{92}$ In May the Government destroyed 52 Bedouin homes. In addition The Israel Land Administration destroyed Bedouin wheat fields with chemical defoliant as the fields had been planted on unrecognized land. 

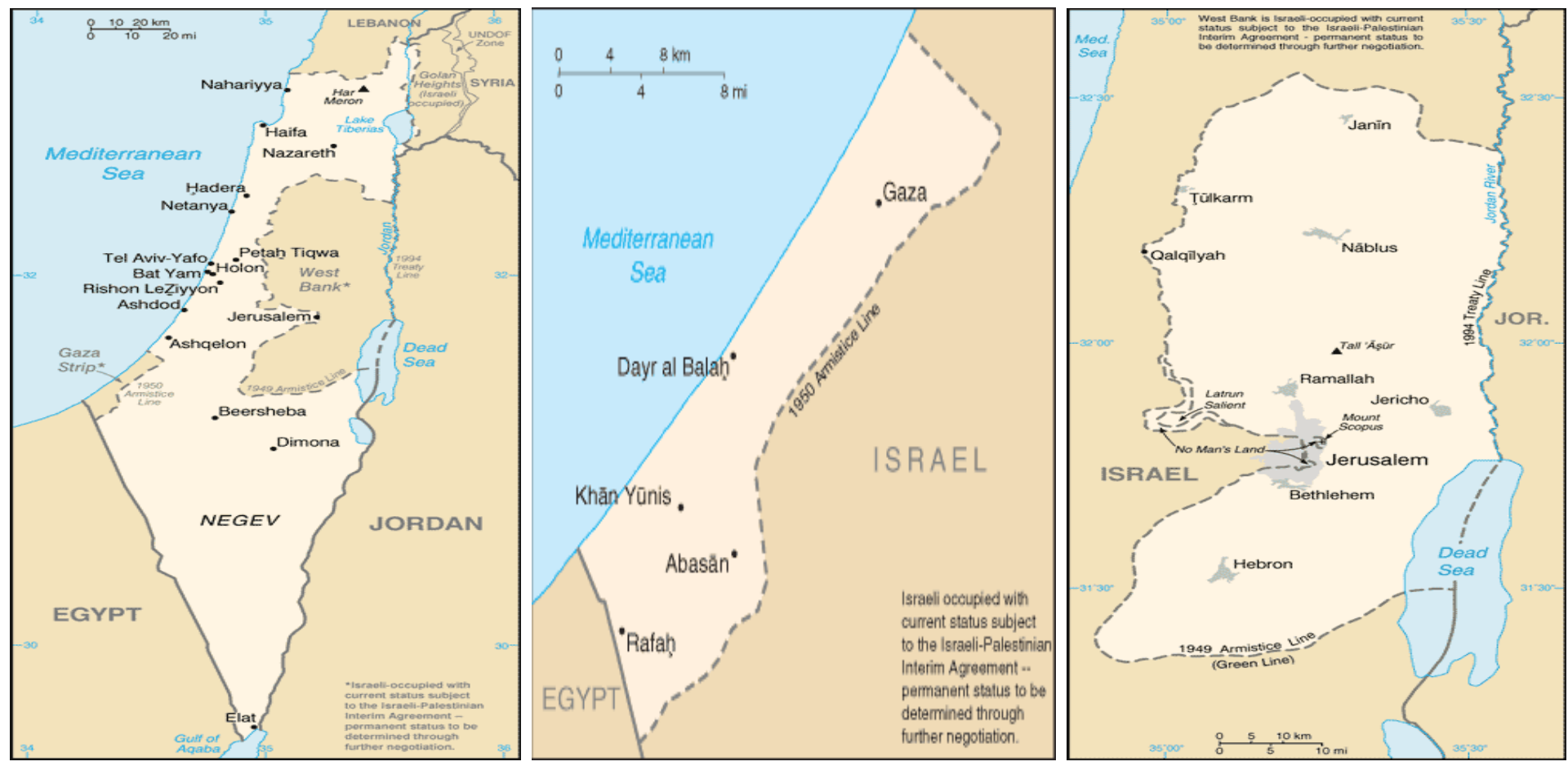

Occupied territories

(Population: Gaza Strip:1,274,868; West Bank: 2,237,194)

\begin{tabular}{|c|c|c|c|c|}
\hline & 1989 & 1990 & 1991 & 1992 \\
\hline $\begin{array}{c}\text { Political } \\
\text { Terrorscale }\end{array}$ & $4 / 4$ & $4 / 3$ & $4 / 3$ & $4 / 4$ \\
\hline Conflict Level & $\begin{array}{l}\text { Low-intensity } \\
\quad \text { conflict }\end{array}$ & $\begin{array}{l}\text { Low-intensity } \\
\text { conflict }\end{array}$ & $\begin{array}{l}\text { Low-intensity } \\
\text { conflict }\end{array}$ & $\begin{array}{l}\text { Low-intensity } \\
\quad \text { conflict }\end{array}$ \\
\hline \multicolumn{5}{|l|}{$\begin{array}{l}\text { Freedom } \\
\text { House }\end{array}$} \\
\hline $\begin{array}{c}\text { U.S. State } \\
\text { Department }\end{array}$ & $\mathrm{E}^{1}, \mathrm{p}^{2}, \mathrm{~T}^{3}, \mathrm{DE}^{6}, \mathrm{DH}^{5}$, & $\begin{array}{l}\mathrm{E}^{7}, \mathrm{p}^{8}, \mathrm{~T}^{9}, \mathrm{AE}^{10}, \\
\mathrm{CL}^{11}, \mathrm{D}^{12}\end{array}$ & $\mathrm{E}^{13}, \mathrm{~T}^{14}, \underset{\mathrm{D}^{17}}{\mathrm{AE}^{15}}, \mathrm{CL}^{16}$, & $\mathrm{E}^{18}, \mathrm{t}^{19}, \underset{\mathrm{D}^{22}}{\mathrm{AE}^{20}}, \mathrm{CL}^{21}$, \\
\hline
\end{tabular}

\begin{tabular}{|c|c|c|c|c|}
\hline & 1993 & 1994 & 1995 & 1996 \\
\hline $\begin{array}{c}\text { Political } \\
\text { Terrorscale }\end{array}$ & $4 / 4$ & $9 / 4$ & $9 / 4$ & $4 / 4$ \\
\hline Conflict Level & $\begin{array}{c}\text { Low intensity } \\
\text { conflict (great } \\
\text { increase in first five } \\
\text { months) }\end{array}$ & & $\begin{array}{l}\text { Low intensity } \\
\text { conflict (less } \\
\text { casualties than the } \\
\text { previous year) }\end{array}$ & $\begin{array}{l}\text { Low intensity } \\
\text { conflict (Increase in } \\
\text { casualties) }\end{array}$ \\
\hline \multicolumn{5}{|l|}{$\begin{array}{c}\text { Freedom } \\
\text { House }\end{array}$} \\
\hline $\begin{array}{c}\text { U.S. State } \\
\text { Department }\end{array}$ & $\mathrm{E}^{23}, \mathrm{t}^{24}, \underset{\mathrm{D}^{27}}{\mathrm{AE}^{25}}, \mathrm{CL}^{26}$, & $\begin{array}{l}\mathrm{E}^{28}, \mathrm{p}, \mathrm{t}^{29}, \mathrm{AE}^{30} \\
\quad \mathrm{CL}^{31}, \mathrm{D}^{32}\end{array}$ & $\begin{array}{c}\mathrm{e}^{33}, \mathrm{p}^{34}, \mathrm{t}^{35}, \mathrm{AE}^{36}, \\
\mathrm{CL}^{37}, \mathrm{D}^{38}\end{array}$ & $\begin{array}{l}\mathrm{e}^{39}, \mathrm{p}^{40}, \mathrm{t}^{41}, \mathrm{AE}^{42}, \\
\quad \mathrm{CL}^{43}, \mathrm{D}^{44}\end{array}$ \\
\hline
\end{tabular}




\begin{tabular}{|c|c|c|c|c|}
\hline $\begin{array}{c}\text { Political } \\
\text { Terrorscale }\end{array}$ & $\mathbf{1 9 9 7}$ & $\mathbf{1 9 9 8}$ & $\mathbf{1 9 9 9}$ & $\mathbf{2 0 0 0}$ \\
\hline $\begin{array}{c}\text { Conflict Level } \\
\text { Freedom } \\
\text { House }\end{array}$ & $\begin{array}{c}\text { Violent political } \\
\text { conflict (decrease in } \\
\text { casualties) }\end{array}$ & $\begin{array}{c}\text { Violent political } \\
\text { conflict (decrease in } \\
\text { casualties) }\end{array}$ & $\begin{array}{c}\text { Violent political } \\
\text { conflict (decrease in } \\
\text { casualties) }\end{array}$ & $\begin{array}{c}\text { low intensity conflict } \\
\text { (specifically after } \\
\text { September) }\end{array}$ \\
\hline $\begin{array}{c}\text { U.S. State } \\
\text { Department }\end{array}$ & $\mathrm{e}^{45}, \mathrm{p}^{46}, \mathrm{t}^{47}, \mathrm{AE}^{48}, \mathrm{D}^{49}$ & $\mathrm{e}^{50}, \mathrm{p}^{51}, \mathrm{t}^{52}, \mathrm{AE}^{53}, \mathrm{D}^{54}$ & $\mathrm{e}^{55}, \mathrm{p}^{56}, \mathrm{t}^{57}, \mathrm{AE}^{58}$ & $\begin{array}{c}\mathrm{E}^{59}, \mathrm{p}^{60},(\mathrm{t})^{61}, \mathrm{D}^{62}, \\
\mathrm{AE}^{63}, \mathrm{FE}^{64}\end{array}$ \\
\hline
\end{tabular}

\begin{tabular}{|c|c|c|}
\hline & 2001 & 2002 \\
\hline \multicolumn{3}{|l|}{$\begin{array}{l}\text { Political } \\
\text { Terrorscale }\end{array}$} \\
\hline Conflict Level & $\begin{array}{c}\text { low intensity conflict } \\
\text { (sharp increase in } \\
\text { casualties) }\end{array}$ & $\begin{array}{c}\text { high intensity } \\
\text { conflict (around } 1150 \\
\text { casualties) }\end{array}$ \\
\hline \multicolumn{3}{|l|}{$\begin{array}{l}\text { Freedom } \\
\text { House }\end{array}$} \\
\hline $\begin{array}{c}\text { U.S. State } \\
\text { Department }\end{array}$ & $\begin{array}{l}\mathrm{E}^{65}, \mathrm{p}^{66}, \mathrm{~T}^{67}, \mathrm{AE}^{68} \\
\mathrm{PC}^{69}, \mathrm{D}^{70}, \mathrm{FE}^{71}, \mathrm{IF}^{72}\end{array}$ & $\begin{array}{c}\mathrm{E}^{73}, \mathrm{p}^{74}, \mathrm{~T}^{75}, \mathrm{D}^{76} \\
\mathrm{AE}^{77}, \mathrm{IF}^{78}\end{array}$ \\
\hline
\end{tabular}

\section{Working conditions:}

1990: According to international labor organizations, health and safety conditions in some factories do not meet industry standards established by the ILO.

1991: According to international labor organizations, health and safety conditions in some factories do not meet industry standards established by the ILO.

1992: Health and safety conditions in some factories do not meet industry standards established by international labour union organisations.

1993: Health and safety conditions in some factories do not meet industry standards established by international labour union organisations.

1994: The Israeli Ministry of Labor's Office of Inspection Services has been responsible for enforcing safety standards in the West Bank. It maintains that it has undertaken inspections, however, Palestinian factories and other businesses in the West Bank and Gaza often do not meet international standards.

1995: The Israeli Ministry of Labor's Office of Inspection Services has been responsible for enforcing safety standards in the West Bank. It maintains that it has undertaken inspections, however, Palestinian factories and other businesses in the West Bank and Gaza often do not meet international standards.

\section{Brief historical/political overview}

1987: In December there is a dramatic outburst of civilian unrest and violence.

1989: The violence of 1987 continues and it has been far more widespread and intensive than at any time before. 432 Palestinians died of intifada-related violence, of whom 304 were killed by Israeli security forces and settlers and 128 by other palestinians. 13 Israelis, soldiers and civilians, were killed by Palestinians. Important in the 1989 report is the sharp increase in violence between Palestinians. 
Hundreds of curfews, some lasting several weeks, were imposed. These curfews caused severe hardship. Crimes against Israelis are punished more severely that crimes against Palestinians.

1990: The violence and crackdown of this violence from 1987 continued into 1990. The violence somewhat declined in July, August and September. However a series of incidents and the support by Palestinians of Saddam Hussain led to heightening tensions in the last quarter of the year. There was a great increase in the number of killings by Palestinians on Palestinians (165). 130 Palestinians were killed by Israeli security forces and 11 by Israeli civilians. In the last part of 1990 endorsements of "all forms of struggle" against Israel, including "massive martyrdom" and "suicide operations", appeared in intifada-related literature. These were accompanied by an increase in violence. The number of curfews and their length declined during the year. Settlers involved in security violations are treated far more leniently than Palestinians. Under the system of dual governance Palestinians are treated less favorably than Israeli settlers on a broad range of issues.

1991: The violence was significantly reduced. As a result of Palestinian support for Iraq during the Gulf War Israel imposed a month long 24 hour curfew on Gaza and the West Bank. This caused great hardship. Palestinians killed 12 Israeli soldiers and citizens. Four Palestinians were killed by Israeli citizens. 97 Palestinians were killed by Israeli security forces. 140 Palestinians were killed by other Palestinians. Settlers involved in security violations are treated far more leniently than Palestinians. Under the system of dual governance Palestinians are treated less favorably than Israeli settlers on a broad range of issues. Prior to the Gulf War gas masks were distributed to Israeli citizens, but not to Palestinians.

1992: Negotiations, including the subject of elections, between Palestinians are ongoing to establish an interim self-governing authority which would give Palestinians greater control over the economic and political decisions affecting their lives. Violence continued to subside in 1992. 182 Palestinians were killed by fellow Palestinians. 158 Palestinians were killed by security forces, including 45 that were killed by undercover units. 23 Israeli soldiers and civilians were killed by Palestinians. Curfews were used less extensively. Crimes against Israelis are punished more severely that crimes against Palestinians. Palestinians are treated less favorably than Israeli settlers on a broad range of issues. 415 alleged members of Hamas were deported to Lebanon.

1993: Violence and confrontation increased dramatically during the first five months of the year. After a series of killings and stabbings of Israeli soldiers and civilians in Israel and the occupied territories during the first 3 months of the year. Israeli decided to seal of indefinitely West Bank, Gaza from Jerusalem and Israel. This caused, among others, a deterioration of the economic situation. On September 13 the Declaration of Principles on a gradual transfer of authority from Israel to an interim Palestinian self governing authority is signed. The Declaration lays out a timetable for Israeli withdrawal from the Gaza Strip and Jericho, scheduled to be completed in the first quarter of 1994. In addition the Declaration calls for the redeployment of Israeli security forces away from populated areas in the West Bank by as early as July 1994, which is the target date for election of Palestinian Council and for the dissolution of the Israeli-military backed CIVAD which has administered the occupied territories since 1981. Through this process, Palestinians will also assume early responsibility for functions such as the health sector, educational, cultural, and socila welfare affairs; tourism; and taxation. The Palestinians are also to create a Palestinian police force for the occupied territories. Israelis are to continue to control external security, internal security, and public order, in Israeli settlements, foreign relations, and other areas until an agreement on permanent status is achieved. All 415 deported alleged Hamas members were allowed to return. Six settlers were killed by Palestinians. 8 Palestinians were killed by settlers. Curfews were used less frequently in West Bank. However curfews were used extensively in Gaza. 49 Israelis were killed in the occupied territories by Palestinians attacks. 79 Palestinians were killed by fellow Palestinians. 184 Palestinians were killed by security forces.

1994: In May Israel began transferring most responsibilities for civil government in the Gaza Strip and Jericho Area to the Palestinian Authority (PA). Palestinians killed 23 Israelis in the West Bank and Gaza and 52 within Israel. Israeli settlers killed 37 Palestinians. (most, 29 killed, in one incident). Palestinians killed 65 Palestinians. 108 Palestinians were killed by Israeli security forces. After 40 Israelis died in a series of terrorist attacks the GSS decided in November to allow interrogators greater flexibility in applying guidelines established by the 1987 Landau Commission.

1995: The Israeli-Palestinian Interim Agreement on the West Bank and the Gaza Strip (the Interim Agreement) is signed on September 28, 1995. Late 1995 Israel begins redeploying its forces from the 
West Bank and turning over major towns and surrounding villages to PA administration. Now the PA exercises authority over about 2.2 million Palestinians in the West Bank and Gaza Strip. The Interim Agreement also provides for the redeployment of Israeli Forces and modalities for elections for the Palestinian Council and the chief executive of its Executive Authority. In January 1996 Palestinians voted in their first democratically elected representative body. Arafat was elected chief executive of the 88 -member Palestinian Council, with $89 \%$ of votes. Though there were some irregularities the elections were generally satisfactory. Number of killings dropped dramatically and the number of confrontations between security forces and Palestinians also declined dramatically over the past two years. Four palestinians were killed by settlers. Isreali security forces killed 47 Palestinians. Israeli settlers are treated more favorably than Palestinians under the laws governing the territories.

1996: Economic situation deteriorated significantly due to closures. Three Palestinians were killed by settlers. 8 Palestinians were killed by other Palestinians. Palestinians killed 4 Osraeli soldiers and civilians in the West Bank and PA areas and 58 people in terrorist bombings in Israel. Opening of controversial tunnel in Jerusalem's old city sparks of mass demonstrations and violence.

1997: Negotiations on the final status of the occupied territories as well as of Jerusalem, borders, Israeli settlements, refugees and other matters began in May 1996, were immediately adjourned and have not as yet started. At least 25 Israelis killed by Palestinians. 10 Palestinians killed by Israeli security forces. 2 Palestinians killed by other Palestinians.

1998: Permanent status talks resumed in November. Israel more frequently tightened closures in the latter half of the year. Sixteen Palestinians were killed by Israeli security forces. Eight Palestinians were killed by Israeli citizens. Nine Israelis were killed by Palestinian terrorist groups.

1999: Permanent status talks continued. Less stringent application of closure policy than in previous year. There were no "internal"closures (closures preventing flow of goods and persons between towns and villages in the West Bank). Israel's human rights record improved. PA human rights record worsened. One Palestinian was killed by an Israeli citizen. Two Palestinians were killed by Israeli security forces. In a shootout one undercover Israeli policeman and one HAMAS terrorist was killed.

2000: Following the visit, on September 28, to Temple Mount, by oposition leader Ariel Sharon, violence erupted. Since this eruption clashes between Palestinians and IDF soldiers occurred daily. The uprising is known as the "al-Aqsa Intifada". Due to the unrest there were a total of 88 days of tightened closures and 81 days of internal closures. This is a sharp increase from 1999. The closures severely empoverished Palestinians. Israeli human rights record improved slightly during the first nine months of the year, but worsened after the outbreak of violence. 307 Palestinians were killed by security forces. 82 of those killed were under the age of 18. A number of Palestinians were killed in targeted shootings. 7 Palestinians died in shelling of PA institutions. Pa human rights record worsened after the eruption of violence. Several Israelis were killed by PA security forces. Settlers killed 14 Palestinians. Palestinians killed at least 18 Israeli civilians. Seven Israelis were killed in bomb attacks.

2001: Nature of the violence by Palestinians changed, as there were more armed attacks and acts of terrorism. Efforts to curb the violence by way of recommendations by the Mitchell Committee and the Tenet plan failed. Closures and increased restrictions further empoverished the Palestinian economy. There 210 days of total external closures and 155 days of partial external closure. (compared to 88 in 2000 and 15 in 1999). There were 87 days of limited internal closure and 278 days of severe internal closure in the West Bank ( 81 days in 2000 and none in 1999). There were 361 days of limited internal closure and 4 days of severe internal closure in Gaza. Israeli human rights record continued to deteriorate. At least 501 Palestinians and 1 foreign national were killed by security forces. This figure of 501 included: at least 33 Palestinians were killed in targetted killings; at least 18 other persons, including 4 children, killed by Israeli forces in those operations were bystanders, relatives, or associates of those killed; 93 Palestinians were killed in shelling of PA institutions and Palestinian civilian areas; 68 Palestinians were killed during incursions into Palestinian controlled territory; and at least 32 Palestinians died because the were refused medical assistance. At least 19 Palestinians were killed by Israeli settlers. Palestinians killed 87 Israelis (including 51 by terrorist acts). Palestinians killed at least 22 Palestinians accused of collaborating with Israel. Israel's Minister for Tourism is killed. Children were badly affected by the violent security situation, which interfered with learning and which was manifesting itself in lack of focus, nightmares, daytime and nightmare incontinence, and other behavioral problems. 
2002: Nature of the violence changed more and was marked by increased military operations and armed attacks and terrorism by Palestinians against Israeli targets. By year's end, Israel reasserted military control, which placed all major West Bank cities except Jericho under IDF control. Closures continued to affect the Palestinian economy. Poverty and unemployment increased during the year. Israel imposed complete external closure on the West Bank and strict internal closure in the West Bank, for the entire year. Israeli forces further imposed extended curfews on Palestinian towns or neighborhoods. 990 Palestinians and 2 foreign nationals were killed by Israeli forces. At least 37 Palestinians were killed in targeted killings. During these actions 25 bystanders (including 13 children) were killed. At least five Palestinians were killed by settlers. Palestinians killed 189 Israelis (civilians and security personnel). Palestinians killed at least 35 Palestinians suspected of collaboration with Isael. Incursion into Jenin: 140 homes destroyed, 200 others structurally unsound and 52 Palestinians killed (including 22 unarmed civilians). Israeli and the PA sanctioned the voluntary agreement of 13 Palestinian gunmen to go into exile in Europe and another 35 to Gaza in a negotiated resolution of the standoff at the Church of the Nativity in Bethlehem in the spring. Children were badly affected by the violent security situation, which interfered with learning and which was manifesting itself in lack of focus, nightmares, daytime and nightmare incontinence, and other behavioral problems.

\footnotetext{
${ }^{1}$ Ten detainees died after severe beatings. There are allegations that Israeli security forces or Palestinians working for them have intentionally killed Palestinian activists. Israel denies this. Moreover security forces used excessive lethal force trying to disperse demonstrations. This resulted in around 400 deaths.

${ }^{2}$ Serious overcrowding in at least one IDF detention centre and conditions in military detention facilities varied. Several prison riots and hunger strikes were held to protest against prison conditions.

${ }^{3}$ Severe beatings is torture and several torture techniques were said to be applied by security forces. Although in 1987 the Landau Commission condemned the use of torture it did distinguish it from "a moderate measure of physical pressure".

${ }^{4}$ Israel kept all Palestinian Universities closed during the year. The vocational, secondary and elementary schools in the West Bank. closed in January, reopened in July and August, but were closed again in mid-November. Schools in Gaza and East Jerusalem were open for most of the year. Alternate, of-campus classrooms organized by parents and teachers were banned on security grounds, although some continued to operate.

${ }^{5}$ Discrimination which favors settlers.

${ }^{6}$ During the year 170 houses were demolished or sealed for security reasons ( 88 demolished, 82 sealed) for security reasons.

${ }^{7}$ Five wanted Palestinian activists were intentionally killed by security forces according to several human rights groups. During the year 130 Palestinians were killed by Israeli security forces. At least a number of those were killed using excessive lethal force. During the year Israeli authorities received complaints on 3 Palestinian deaths attributed to beatings.

${ }^{8}$ Serious overcrowding in at least one IDF detention centre and conditions in military detention facilities varied.

${ }^{9}$ The report enumerates a number of interrogation techniques, they are considered torture. Although in 1987 the Landau Commission condemned the use of torture it did distinguish it from "a moderate measure of physical pressure".

${ }^{10}$ Schools, colleges and universities reopened during the year. However they were temporarily closed during certain periods and four West Bank and Gaza universities remained closed during the whole year.

${ }^{11}$ Underage labour is used in the agricultural sector and in some West Bank and Gaza factories.

1294 houses were demolished and 83 houses were sealed, for security reasons. This is a slight increase from the preious year. 150 houses were demolished in the West Bank, because they were built without a permit.

${ }_{13} 27$ Palestinians, many of whom were unarmed are known to have been killed by nonuniformed security personnel. Palestinian and human rights groups claim that many of these individuals were killed without warning or after surrendering or having been subdued. 97 Palestinians were killed by security forces, some of these will have been the result of excessive use of force.

${ }^{14}$ There were credible reports of torture. Among these reports were eight allegations of electric shock torture. Many of the torture takes place just after arrest or within days after arrest.

${ }^{15}$ Schools were open for $40 \%$ of the time, due to strikes and curfews. One university remained closed.

${ }^{16}$ Underage labour is used in the agricultural sector and in some West Bank and Gaza factories.

${ }^{17} 55$ houses were demolished and 62 sealed for security reasons. Israeli authorities report 43 demolitions and 58 sealings.

${ }^{18} 45$ Palestinians, two-thirds of whom were unarmed, are known to have been killed by nonuniformed security personnel. Palestinian and human rights groups claim that some could have been aprehended without killing them. 5 Palestinians were killed in custody, two of which apparently were suicides. 158 Palestinians were killed by security forces, some of these will have been the result of excessive use of force.

${ }^{19}$ There was widespread abuse, some of which amounted totorture.

${ }^{20}$ Individual schools were closed for periods during the year. The last Palestinian university to be closed was reopened in April. Closures affected the possibility of access to education.

${ }^{21}$ Underage labour is used in the agricultural sector and in some West Bank and Gaza factories.

2212 houses were demolished and 33 sealed for security reasons.

${ }^{23} 27$ Palestinians were killed by undercover units disguised as Palestinians. Palestinian and human rights groups claim that some could have been aprehended without killing them. Some of the deaths could have been extrajudicial killings. 184 Palestinians were killed by security forces, some of these will have been the result of excessive use of force. At least one Palestinian was killed in an extrajudicial killing when in custody of the Israelis. In all six palestinians died in Israeli custody.
} 
Four of which seem to have died from natural causes. However it seems that the lack of prompt and adequate medical attention has contributed to three of these deaths.

${ }^{24}$ There was widespread abuse, some of which amounted torture.

${ }^{25}$ Closures disrupted the acces to education. Many Palestinian women face lack of education. Schools reamin overcrowded and underfunded, Closings by both Israel and Palestinian activists enforcing strikes have had a negative imact on the access to education.

${ }^{26}$ Underage labour is used in the agricultural sector and in some West Bank and Gaza factories.

${ }^{27} 3$ houses were demolished and 27 sealed for security reasons. Houses were also severely damaged and destroyed because of the use of heavy weapons by Israelis targeting houses believed to hide security suspects. 220 houses were reportedly destroyed or partially damaged.

${ }^{28} 13$ Palestinians were killed by undercover units disguised as Palestinians. Palestinian and human rights groups claim that some could have been aprehended without killing them. Some of the deaths could have been extrajudicial killings. 108 Palestinians were killed by security forces, some of these will have been the result of excessive use of force.

${ }^{29}$ There was widespread abuse, some of which amounted torture.

${ }^{30}$ Most Palestinians encountered problems in getting permits, including permits to study. Closures hampered the flow of students.

${ }^{31}$ Underage labour is used in the agricultural sector and in some West Bank and Gaza factories.

321 house were demolished and 5 sealed for security reasons. 12 houses were destroyed when Israeli forces used heavy weapons to destroy houses believed to be hiding places for security suspects.

3310 Palestians were killed by Israeli undercover units disguised as Palestinians. At least some of the Palestinians were killed without an opportunity to surrender and when they could be captured alive. 1 Palestinian died in Israeli detention as a result of torture. Some others died apparently, because of a lack of prompt and adequate medical care. 47 persons were killed by Israeli security forces, some of which might have been/or were the consequence of excessive lethal force.

34 Conditions are harsh. Palestinian inmates undertook several hunger strikes. Prisoners criticized overcrowding, mistreatment, filthy and deteriorating conditions of cells and tents, inadequate medical care, extended use of solitary confinement, and in some cases, lack of visits by lawyers.

${ }^{35}$ There was widespread abuse, some of which amounted torture. Though there was a sharp decrease in the number of arrests there was a sharp increase in the number of complaints of torture. Interrogators are allowed to use 'special measures' that exceed the use of "moderate physical and psychological pressure" allowed in the Landau Commission guidelines when it is deemed necessary to obtain information that could potentially save Israeli lives in certain "ticking bomb" cases. There is a growing public debate whether some of those "special measures" (also used during the year) constitute torture.

${ }_{36}$ Most Palestinians encountered problems in getting permits, including permits to study. Closures hampered the flow of students.

${ }^{37}$ Underage labour is used in the agricultural sector and in some West Bank and Gaza factories.

${ }^{38}$ One house was demolished for security reasons. One staircase in a house was sealed. 5 houses were destroyed in military operations.

${ }^{39} 4$ Palestinians were killed by Israeli undercover units disguised as Palestinians. At least some of the Palestinians were killed without an opportunity to surrender and when they could be captured alive. One Palestinian was shot by soldiers at a checkpoint after having obeyed a stop sign, but put his vehicle in reverse. 2 Palestinians died in Israeli detention as a result of torture, one of them seems to have ben tortured by fellow Palestinian inmates. 59 persons were killed by Israeli security forces, some of which were the result of excessive lethal force.

${ }^{40}$ Conditions are poor. Facilities are overcrowded, sanitation is poor, and medical care is inadequate.

${ }^{41}$ There was widespread abuse, some of which amounted torture. Israeli authorities also frequently treat Palestinians in an abusive manner at checkpoints. Complaints of such abuse increased.

${ }^{42}$ Most Palestinians encountered problems in getting permits, including permits to study. Closures hampered the flow of students.

${ }^{43}$ Underage labour is used in the agricultural sector and in some West Bank and Gaza factories.

${ }^{44}$ Eight houses were demolished for security reasons. One house was sealed. Eight houses where suspected/convicted suicidebombers lived were destroyed.

${ }^{45} 2$ Palestinians were killed by Israeli undercover units disguised as Palestinians. One of those who died was beaten to death and denied medical care for a gunshot wound to the leg. 1 Palestinians died in Israeli detention as a result of a beating. 4 Palestininas were killed at checkpoints after either having failed to stop or having tried to attack the security forces. 10 persons were killed by Israeli security forces, some of which were the result of excessive lethal force.

${ }^{46}$ Conditions are poor. Facilities are overcrowded, sanitation is poor, and medical care is inadequate.

${ }^{47}$ There was widespread abuse, some of which amounted torture. Israeli authorities also frequently treat Palestinians in an abusive manner at checkpoints.

${ }^{48}$ Most Palestinians encountered problems in getting permits, including permits to study. Closures hampered the flow of students.

${ }^{49}$ Eight houses were destroyed.

${ }^{50} 4$ Palestininas were killed at checkpoints after having failed to stop or having tried to attack the security forces, according to Israeli authorities. Palestinians dispute these accounts. 16 persons were killed by Israeli security forces, some of which were the result of excessive lethal force. Two Palestinian security detainees died in custody. One died from an alleged suicide attempt and the other due to inadequate medical treatment and subsequent mistreatment.

${ }^{51}$ Conditions are poor. Facilities are overcrowded, sanitation is poor, and medical care is inadequate. 
${ }^{52}$ There was widespread abuse, some of which amounted torture. B'tselem found that a large percentage of Palestinian detainees it surveyed had been tortured while in Israeli detention. Israeli authorities also frequently treat Palestinians in an abusive manner at checkpoints.

${ }^{53}$ Most Palestinians encountered problems in getting permits, including permits to study. Closures hampered the flow of students.

${ }^{54}$ One house was destroyed.

${ }^{55}$ Three Palestinians were killed at checkpoints after having failed to stop or having tried to attack the security forces, according to Israeli authorities. Palestinians dispute these accounts. 2 persons were killed by Israeli security forces, these deaths were the result of excessive lethal force.

${ }^{56}$ Conditions are poor. Facilities are overcrowded, sanitation is poor, and medical care is inadequate.

${ }^{57}$ Israeli forces abused, and in some cases tortured detainees. In a September landmark decision by the Israeli High Court of Jjustice, the court prohibited the use of a variety of abusive practices, including violent shaking, painful shackling in contorted positions, sleep deprivation for extended periods of time, and prolonged exposure to extreme periods. Following the ruling there were no credible reports of such abuses by security forces. The court explicitely rejected claims by the Israeli Government that the practices mentioned were "moderate physical pressure" and therefore permissible under the law, though the possibility was left open that such practices might be acceptable if specifically authorized by new legislation. Israeli authorities also sometimes treat Palestinians in an abusive manner at checkpoints.

${ }^{58}$ Most Palestinians encountered problems in getting permits, including permits to study. Closures hampered the flow of students. Israeli permit policies affect Palestinian schools as they have not always been built with the right permits.

${ }^{59} 307$ Palestinians were killed by security forces, of which 227 (and 4 foreign nationals) were killed after the outbreak of violence. In many instances security forces used excessive force. 82 of those killed were under the age of 18. 10 Palestinians were deliberately targeted by the IDF. During these incidents 6 Palestinian bystanders were killed. Many Palestinians were shot in unclear circumstances. Prior to the outbreak 3 Palestinians were killed at checkpoints. Circumstances surrounding these deaths are unclear. One Palestinian died in Israeli custody.

${ }^{60}$ Conditions are poor. Facilities are overcrowded, sanitation is poor, and medical care is inadequate.

${ }^{61}$ Due to the outbreak of violence, Human rights groups have not been able to substantiate sporadic claims of torture. Israeli authorities also frequently treat Palestinians in an abusive manner at checkpoints.

${ }^{62}$ Three homes were destroyed by security forces. From late September through the end of the year the IDF destroyed numerous citrus orchards, olive and date groves, and irrigation systems on Palestinian-owned agricultural land. Property was severely damaged in attacks by Israeli tanks and helicopters.

${ }^{63}$ Most Palestinians encountered problems in getting permits, including permits to study. Closures hampered the flow of students. Closures affected student's ability to attend school. In areas under curfew all classes were cancelled. Furthermore, teachers were unable to reach their schools in different villages and towns.

${ }^{64} 300$ Bedouin farmers were expelled from their homes in caves near a jewish settlement. Although the High Court ordered that the farmers were allowed back, the IDF issued new deportation orders to those farmers that were not party to the original legal suit. The farmers were deported in 1999, but the report of 2000 mentions them for the first time. The High Court decision stems from 2000.

${ }^{65}$ At least 501 Palestinians and 1 foreign national were killed by security forces. The security forces frequently used excessive force. At least 33 Palestinians were killed in targetted killings. At least 18 other persons, including 4 children, killed by Israeli forces in those operations were bystanders, relatives, or associates of those killed. 93 Palestinians were killed in shelling of PA institutions and Palestinian civilian areas. 68 Palestinians were killed during incursions into Palestinian controlled territory. At least 32 Palestinians died because the were refused medical assistance. A number of persons were killed "in ambiguous circumstances that appeared to involve the excessive use of force". At least two Palestinian prisoners died in Israeli custody.

${ }^{66}$ Conditions are poor. Facilities are overcrowded, sanitation is poor, and medical care is inadequate.

${ }^{67}$ There was a great increase in the number of reports of torture. All techniques banned by a Septmeber 1999 High Court ruling were used again.

${ }^{68}$ Most Palestinians encountered problems in getting permits, including permits to study. Closures hampered the flow of students. Closures affected student's ability to attend school. In areas under curfew all classes were cancelled. Furthermore, teachers were unable to reach their schools in different villages and towns. East Jerusalem schools remained underfunded and overcrowded, and many students were denied an education in public schools due to lack of space.

${ }^{69}$ Some 80 minors were held in cells together with convicted adult Israeli criminals. These children were frequently abused by the adults and prison staff.

${ }^{70}$ Numerous houses were destroyed by security forces without permission. The IDF destroyed numerous citrus orchards, olive and date groves, and irrigation systems on Palestinian-owned agricultural land. Property was severely damaged in attacks by Israeli tanks and helicopters.

${ }^{71}$ Bedouin farmers and their families were expelled from their homes in caves near a jewish settlement. In 2000 the High Court ordered that the farmers expelled in 1999 were allowed back, the IDF issued new deportation orders to those farmers that were not party to the original legal suit. These deportations were given effect in 2001.

${ }^{72}$ Due to the closures there was a shortage of water and food.

${ }^{73} 990$ Palestinians and 2 foreign nationals were killed by Israeli forces. The security forces frequenntly used excessive force. At least 37 Palestinians were killed in targeted killings. During these actions 25 bystanders (including 13 children) were killed. At least 14 Palestinians died because the were refused medical assistance. 2 Palestinians were killed in custody. 
${ }^{74}$ Conditions for Palestinians in Israeli prisons are poor. Facilities are overcrowded, sanitation is poor, and at times food and clothing were insufficient. The authorities were ill-prepared for the great number of arrests and failed to accommodate the thousands of Palestinians properly.

${ }^{75}$ There was a another increase in the number of reports of torture. All techniques banned by a Septmeber 1999 High Court ruling were used again. Many Palestinians were abused at chechpoints. Israeli security personnel on patrol abused and in some cases tortured Palestinian civilians.

${ }^{76} 114$ houses were destroyed by security forces as punishment for terror activity. The IDF destroyed numerous citrus orchards, olive and date groves, and irrigation systems on Palestinian-owned agricultural land.

${ }^{77}$ Closures and curfews hampered the flow of students. Closures and curfews affected student's ability to attend school. In areas under curfew all classes were cancelled. Furthermore, teachers were unable to reach their schools in different villages and towns. East Jerusalem schools remained underfunded and overcrowded, and many students were denied an education in public schools due to lack of space.

${ }^{78}$ Curfews caused food shortages and shortage of water. 


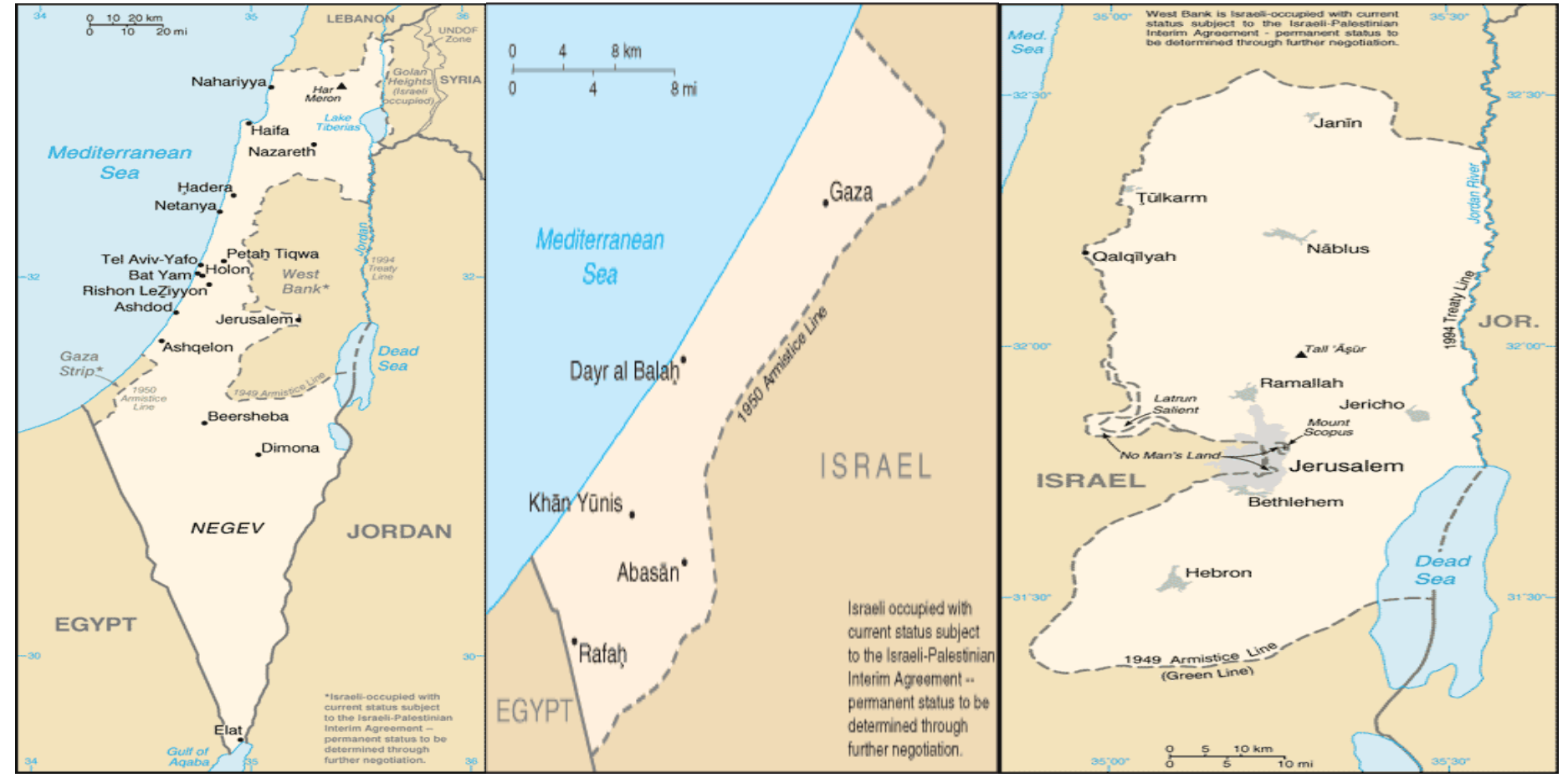

\section{Palestinian Authority}

(Population: Gaza Strip:1,274,868; West Bank: 2,237,194)

\begin{tabular}{|c|c|c|c|c|}
\hline & 1989 & 1990 & 1991 & 1992 \\
\hline $\begin{array}{c}\text { Political } \\
\text { Terrorscale }\end{array}$ & $4 / 4$ & $4 / 3$ & $4 / 3$ & $4 / 4$ \\
\hline Conflict Level & & & & \\
\hline $\begin{array}{c}\text { Freedom } \\
\text { House }\end{array}$ & & & & \\
\hline $\begin{array}{c}\text { U.S. State } \\
\text { Department }\end{array}$ & & & & \\
\hline
\end{tabular}

\begin{tabular}{|c|c|c|c|c|}
\hline & 1993 & 1994 & 1995 & 1996 \\
\hline $\begin{array}{c}\text { Political } \\
\text { Terrorscale }\end{array}$ & $4 / 4$ & $9 / 4$ & $9 / 4$ & $4 / 4$ \\
\hline Conflict Level & & & $\begin{array}{c}\text { Low intensity } \\
\text { conflict }\end{array}$ & $\begin{array}{c}\text { low intensity conflict } \\
\text { (increase in } \\
\text { casualties) }\end{array}$ \\
\hline $\begin{array}{c}\text { Freedom } \\
\text { House }\end{array}$ & & $\mathrm{e}^{1}, \mathrm{p}^{2}, \mathrm{CL}^{3}$ & $\mathrm{e}^{4}, \mathrm{p}^{5}, \mathrm{t}^{6}, \mathrm{CL}^{7}$ & $\mathrm{e}^{8}, \mathrm{P}^{9}, \mathrm{t}^{10}, \mathrm{AE}^{11}, \mathrm{CL}^{12}$ \\
\hline $\begin{array}{c}\text { U.S. State } \\
\text { Department }\end{array}$ & & & & \\
\hline
\end{tabular}




\begin{tabular}{|c|c|c|c|c|}
\hline & 1997 & 1998 & 1999 & 2000 \\
\hline \multicolumn{5}{|l|}{$\begin{array}{c}\text { Political } \\
\text { Terrorscale }\end{array}$} \\
\hline Conflict Level & $\begin{array}{c}\text { Violent political } \\
\text { conflict (decrease in } \\
\text { casualties) }\end{array}$ & $\begin{array}{c}\text { Violent political } \\
\text { conflict (decrease in } \\
\text { casualties) }\end{array}$ & $\begin{array}{c}\text { Violent political } \\
\text { conflict (decrease in } \\
\text { casualties) }\end{array}$ & $\begin{array}{l}\text { low intensity conflict } \\
\text { (specifically after } \\
\text { September) }\end{array}$ \\
\hline \multicolumn{5}{|l|}{$\begin{array}{l}\text { Freedom } \\
\text { House }\end{array}$} \\
\hline $\begin{array}{c}\text { U.S. State } \\
\text { Department }\end{array}$ & $\mathrm{e}^{13}, \mathrm{P}_{\mathrm{CL}}^{14}, \mathrm{t}^{15}, \mathrm{AE}^{16}$ & $\mathrm{e}^{18}, \mathrm{P}_{\mathrm{CL}^{19}} \mathrm{~T}^{20}, \mathrm{AE}^{21}$ & $\mathrm{e}^{23}, \mathrm{P}_{\mathrm{CL}}^{24}, \mathrm{~T}^{25}, \mathrm{AE}^{26}$ & $\mathrm{e}^{28}, \mathrm{P}_{\mathrm{CL}}^{29}, \mathrm{~T}^{30}, \mathrm{AE}^{31}$ \\
\hline
\end{tabular}

\begin{tabular}{|c|c|c|}
\hline $\begin{array}{c}\text { Political } \\
\text { Terrorscale }\end{array}$ & $\mathbf{2 0 0 1}$ & $\mathbf{2 0 0 2}$ \\
\hline Conflict Level & $\begin{array}{c}\text { low intensity conflict } \\
\text { (sharp increase in } \\
\text { casualties) }\end{array}$ & $\begin{array}{c}\text { high intensity } \\
\text { conflict (around } 1150 \\
\text { casualties) }\end{array}$ \\
\hline $\begin{array}{c}\text { Freedom } \\
\text { House }\end{array}$ & & \\
\hline $\begin{array}{c}\text { U.S. State } \\
\text { Department }\end{array}$ & $\mathrm{e}^{33}, \mathrm{P}^{34}, \mathrm{~T}^{35}, \mathrm{AE}^{36}$, & $\mathrm{e}^{39}, \mathrm{p}^{40}, \mathrm{~T}^{41}, \mathrm{AE}^{42}$, \\
$\mathrm{CF}^{33}$
\end{tabular}

\section{Working conditions:}

1996: The Palestinian Authority Ministry of Labour is responsible for enforcing safety standards in the West Bank and the Gaza Strip. Newer Palestinian factories and other businesses in the West Bank and Gaza meet international standards, whereas older ones fail to meet international minimum standards.

1997: The Palestinian Authority Ministry of Labour is responsible for enforcing safety standards in the West Bank and the Gaza Strip. Newer Palestinian factories and other businesses in the West Bank and Gaza meet international standards, whereas older ones fail to meet international minimum standards. There is no specific legal protection afforded to workers that allows them to remove themselves from an unhealthy or unsafe work setting without risking loss of employment.

1998: The Palestinian Authority Ministry of Labour is responsible for enforcing safety standards in the West Bank and the Gaza Strip. Newer Palestinian factories and other businesses in the West Bank and Gaza meet international standards, whereas older ones fail to meet international minimum standards. There is no specific legal protection afforded to workers that allows them to remove themselves from an unhealthy or unsafe work setting without risking loss of employment.

1999: The Palestinian Authority Ministry of Labour is responsible for enforcing safety standards in the West Bank and the Gaza Strip. Newer Palestinian factories and other businesses in the West Bank and Gaza meet international standards, whereas older ones fail to meet international minimum standards. There is no specific legal protection afforded to workers that allows them to remove themselves from an 
unhealthy or unsafe work setting without risking loss of employment. A fire in an unlicensed workshop in Hebron killing 14 young women highlighted the problem of the prevalence of sweatshops.

2000: The Palestinian Authority Ministry of Labour is responsible for enforcing safety standards in the West Bank and the Gaza Strip. Newer Palestinian factories and other businesses in the West Bank and Gaza meet international standards, whereas older ones fail to meet international minimum standards. There is no specific legal protection afforded to workers that allows them to remove themselves from an unhealthy or unsafe work setting without risking loss of employment.

2001: The Palestinian Authority Ministry of Labour is responsible for enforcing safety standards in the West Bank and the Gaza Strip. Inspections were severely hampered by the closures. Newer Palestinian factories and other businesses in the West Bank and Gaza meet international standards, whereas older ones fail to meet international minimum standards. There is no specific legal protection afforded to workers that allows them to remove themselves from an unhealthy or unsafe work setting without risking loss of employment.

2002: The Palestinian Authority Ministry of Labour is responsible for enforcing safety standards in the West Bank and the Gaza Strip. Inspections were severely hampered by the closures. Newer Palestinian factories and other businesses in the West Bank and Gaza meet international standards, whereas older ones fail to meet international minimum standards. There is no specific legal protection afforded to workers that allows them to remove themselves from an unhealthy or unsafe work setting without risking loss of employment.

\section{Brief historical/political overview}

1987: In December there is a dramatic outburst of civilian unrest and violence.

1989: The violence of 1987 continues and it has been far more widespread and intensive than at any time before. 432 Palestinians died of intifada-related violence, of whom 304 were killed by Israeli security forces and settlers and 128 by other palestinians. 13 Israelis, soldiers and civilians, were killed by Palestinians. Important in the 1989 report is the sharp increase in violence between Palestinians. Hundreds of curfews, some lasting several weeks, were imposed. These curfews caused severe hardship. Crimes against Israelis are punished more severely that crimes against Palestinians.

1990: The violence and crackdown of this violence from 1987 continued into 1990. The violence somewhat declined in July, August and September. However a series of incidents and the support by Palestinians of Saddam Hussain led to heightening tensions in the last quarter of the year. There was a great increase in the number of killings by Palestinians on Palestinians (165). 130 Palestinians were killed by Israeli security forces and 11 by Israeli civilians. In the last part of 1990 endorsements of "all forms of struggle" against Israel, including "massive martyrdom" and "suicide operations", appeared in intifada-related literature. These were accompanied by an increase in violence. The number of curfews and their length declined during the year. Settlers involved in security violations are treated far more leniently than Palestinians. Under the system of dual governance Palestinians are treated less favorably than Israeli settlers on a broad range of issues.

1991: The violence was significantly reduced. As a result of Palestinian support for Iraq during the Gulf War Israel imposed a month long 24 hour curfew on Gaza and the West Bank. This caused great hardship. Palestinians killed 12 Israeli soldiers and citizens. Four Palestinians were killed by Israeli citizens. 97 Palestinians were killed by Israeli security forces. 140 Palestinians were killed by other Palestinians. Settlers involved in security violations are treated far more leniently than Palestinians. Under the system of dual governance Palestinians are treated less favorably than Israeli settlers on a broad range of issues. Prior to the Gulf War gas masks were distributed to Israeli citizens, but not to Palestinians.

1992: Negotiations, including the subject of elections, between Palestinians are ongoing to establish an interim self-governing authority which would give Palestinians greater control over the economic and political decisions affecting their lives. Violence continued to subside in 1992. 182 Palestinians were killed by fellow Palestinians. 158 Palestinians were killed by security forces, including 45 that were killed by undercover units. 23 Israeli soldiers and civilians were killed by Palestinians. Curfews were used less extensively. Crimes against Israelis are punished more severely that crimes against Palestinians. Palestinians are treated less favorably than Israeli settlers on a broad range of issues. 415 alleged members of Hamas were deported to Lebanon. 
1993: Violence and confrontation increased dramatically during the first five months of the year. After a series of killings and stabbings of Israeli soldiers and civilians in Israel and the occupied territories during the first 3 months of the year. Israeli decided to seal of indefinitely West Bank, Gaza from Jerusalem and Israel. This caused, among others, a deterioration of the economic situation. On September 13 the Declaration of Principles on a gradual transfer of authority from Israel to an interim Palestinian self governing authority is signed. The Declaration lays out a timetable for Israeli withdrawal from the Gaza Strip and Jericho, scheduled to be completed in the first quarter of 1994. In addition the Declaration calls for the redeployment of Israeli security forces away from populated areas in the West Bank by as early as July 1994, which is the target date for election of Palestinian Council and for the dissolution of the Israeli-military backed CIVAD which has administered the occupied territories since 1981. Through this process, Palestinians will also assume early responsibility for functions such as the health sector, educational, cultural, and socila welfare affairs; tourism; and taxation. The Palestinians are also to create a Palestinian police force for the occupied territories. Israelis are to continue to control external security, internal security, and public order, in Israeli settlements, foreign relations, and other areas until an agreement on permanent status is achieved. All 415 deported alleged Hamas members were allowed to return. Six settlers were killed by Palestinians. 8 Palestinians were killed by settlers. Curfews were used less frequently in West Bank. However curfews were used extensively in Gaza. 49 Israelis were killed in the occupied territories by Palestinians attacks. 79 Palestinians were killed by fellow Palestinians. 184 Palestinians were killed by security forces.

1994: In May Israel began transferring most responsibilities for civil government in the Gaza Strip and Jericho Area to the Palestinian Authority (PA). Palestinians killed 23 Israelis in the West Bank and Gaza and 52 within Israel. Israeli settlers killed 37 Palestinians. (most, 29 killed, in one incident). Palestinians killed 65 Palestinians.

1995: The Israeli-Palestinian Interim Agreement on the West Bank and the Gaza Strip (the Interim Agreement) is signed on September 28, 1995. Late 1995 Israel begins redeploying its forces from the West Bank and turning over major towns and surrounding villages to PA administration. Now the PA exercises authority over about 2.2 million Palestinians in the West Bank and Gaza Strip. The Interim Agreement also provides for the redeployment of Israeli Forces and modalities for elections for the Palestinian Council and the chief executive of its Executive Authority. In January 1996 Palestinians voted in their first democratically elected representative body. Arafat was elected chief executive of the 88 -member Palestinian Council, with $89 \%$ of votes. Though there were some irregularities the elections were generally satisfactory. Number of killings dropped dramatically and the number of confrontations between security forces and Palestinians also declined dramatically over the past two years. Four palestinians were killed by settlers. Isreali security forces killed 47 Palestinians. Israeli settlers are treated more favorably than Palestinians under the laws governing the territories. State security courts are installed to try security cases.

1996: Economic situation deteriorated significantly due to closures. Three Palestinians were killed by settlers. 8 Palestinians were killed by other Palestinians. Palestinians killed 4 Israeli soldiers and civilians in the West Bank and PA areas and 58 people in terrorist bombings in Israel.

1997: Negotiations on the final status of the occupied territories as well as of Jerusalem, borders, Israeli settlements, refugees and other matters began in May 1996, were immediately adjourned and have not as yet started. At least 25 Israelis killed by Palestinians. 10 Palestinians killed by Israeli security forces. 2 Palestinians killed by other Palestinians. The court system in general is recovering from years of neglect; many of the problems predate Palestinian jurisdiction. Judges and staff are underpaid and overworked and suffer from lack of skills and training; court procedures and record-keeping are archaic and chaotic; and the delivery of justice is often slow and uneven.

1998: Permanent status talks resumed in November. Israel more frequently tightened closures in the latter half of the year. Sixteen Palestinians were killed by Israeli security forces. Eight Palestinians were killed by Israeli citizens. Nine Israelis were killed by Palestinian terrorist groups. The court system in general is recovering from years of neglect; many of the problems predate Palestinian jurisdiction. Judges and staff are underpaid and overworked and suffer from lack of skills and training; court procedures and record-keeping are archaic and chaotic; and the delivery of justice is often slow and uneven.

1999: Permanent status talks continued. Less stringent application of closure policy than in previous year. There were no "internal"closures (closures preventing flow of goods and persons between towns 
and villages in the West Bank). Israel's human rights record improved. PA human rights record worsened. One Palestinian was killed by an Israeli citizen. Two Palestinians were killed by Israeli security forces. In a shootout one undercover Israeli policeman and one HAMAS terrorist was killed. Lack of due process is a problem. PA does not always respect court decisions. Municipal elections were to be held in June, however they were not held.

2000: Following the visit, on September 28, to Temple Mount, by oposition leader Ariel Sharon, violence erupted. Since this eruption clashes between Palestinians and IDF soldiers occurred daily. The uprising is known as the "al-Aqsa Intifada". Due to the unrest there were a total of 88 days of tightened closures and 81 days of internal closures. This is a sharp increase from 1999. The closures severely empoverished Palestinians. Israeli human rights record improved slightly during the first nine months of the year, but worsened after the outbreak of violence. 307 Palestinians were killed by security forces. 82 of those killed were under the age of 18. A number of Palestinians were killed in targeted shootings. 7 Palestinians died in shelling of PA institutions. Pa human rights record worsened after the eruption of violence. Several Israelis were killed by PA security forces. Settlers killed 14 Palestinians. Palestinians killed at least 18 Israeli civilians. Seven Israelis were killed in bomb attacks. Lack of due process is a problem. PA frequently does not respect court decisions. The state security court often adjudicates cases that fall far short from the original mandate.

2001: Nature of the violence by Palestinians changed, as there were more armed attacks and acts of terrorism. Efforts to curb the violence by way of recommendations by the Mitchell Committee and the Tenet plan failed. Closures and increased restrictions further empoverished the Palestinian economy. There 210 days of total external closures and 155 days of partial external closure. (compared to 88 in 2000 and 15 in 1999). There were 87 days of limited internal closure and 278 days of severe internal closure in the West Bank (81 days in 2000 and none in 1999). There were 361 days of limited internal closure and 4 days of severe internal closure in Gaza. Israeli human rights record continued to deteriorate. At least 501 Palestinians and 1 foreign national were killed by security forces. This figure of 501 included: at least 33 Palestinians were killed in targetted killings; at least 18 other persons, including 4 children, killed by Israeli forces in those operations were bystanders, relatives, or associates of those killed; 93 Palestinians were killed in shelling of PA institutions and Palestinian civilian areas; 68 Palestinians were killed during incursions into Palestinian controlled territory; and at least 32 Palestinians died because the were refused medical assistance. At least 19 Palestinians were killed by Israeli settlers. Palestinians killed 87 Israelis (including 51 by terrorist acts). Palestinians killed at least 22 Palestinians accused of collaborating with Israel. Israel's Minister for Tourism is killed. Children were badly affected by the violent security situation, which interfered with learning and which was manifesting itself in lack of focus, nightmares, daytime and nightmare incontinence, and other behavioral problems.

2002: Nature of the violence changed more and was marked by increased military operations and armed attacks and terrorism by Palestinians against Israeli targets. Closures continued to affect the Palestinian economy. Poverty and unemployment increased during the year. Israel imposed complete external closure on the West Bank and strict internal closure in the West Bank, for the entire year. Israeli forces further imposed extended curfews on Palestinian towns or neighborhoods. 990 Palestinians and 2 foreign nationals were killed by Israeli forces. At least 37 Palestinians were killed in targeted killings. During these actions 25 bystanders (including 13 children) were killed. At least five Palestinians were killed by settlers. Palestinians killed 189 Israelis (civilians and security personnel). Palestinians killed at least 35 Palestinians suspected of collaboration with Isael. Incursion into Jenin: 140 homes destroyed, 200 others structurally unsound and 52 Palestinians killed (including 22 unarmed civilians). Israeli and the PA sanctioned the voluntary agreement of 13 Palestinian gunmen to go into exile in Europe and another 35 to Gaza in a negotiated resolution of the standoff at the Church of the Nativity in Bethlehem in the spring. By year's end, Israel reasserted military control, which placed all major West Bank cities except Jericho under IDF control. In late 2001, Arafat invoked a state of emergency that granted him broader powers to make arrests, prohibit demonstrations, and take action against political oponents. On May 14, Arafat signed the long-pending Independence of the Judiciary Law and on May 29 the PA Basic Law (however neither law was fully implemented). Children were badly affected by the violent security situation, which interfered with learning and which was manifesting itself in lack of focus, nightmares, daytime and nightmare incontinence, and other behavioral problems. The judicial system was not sophisticated in the protection of children. 
${ }^{1}$ At least one extrajudicial execution. Excessive force was used in a confrontation with demostrators leading to the deaths of 16 persons.

${ }^{2}$ PA took over control of detention facilities in Gaza and Jericho from Israeli security forces in May 1994. The physical conditions at these facilities do not meet minimum international standards. Food and clothing are inadequate. One prison for example was dilapidated and overcrowded.

${ }^{3}$ Underage labour is used in the agricultural sector and in some West Bank and Gaza factories. It is unclear under whom's responsibility this problem falls.

${ }^{4}$ Five Palestinians died in custody of Palestinian police. One of the deaths was accidental, one was due to a preexisting medical condition. Three others are still being investigated. One detainee was reportedly handed over by the police to the 'Fatah Hawks' after which he was shot in full public eye, apparently because he was accused of being a collaborator.

${ }^{5}$ PA took over control of detention facilities in Gaza and Jericho from Israeli security forces in May 1994. The physical conditions at these facilities do not meet minimum international standards. Food and clothing are inadequate. One prison for example was dilapidated and overcrowded.

${ }^{6}$ PA security forces abused and sometimes tortured detainees. This took place after arrest and during interrogation. The Gaza civil police commander issued a circular that forbids torture.

${ }^{7}$ Underage labour is used in the agricultural sector and in some West Bank and Gaza factories. It is unclear under whom's responsibility this problem falls.

${ }^{8}$ Four Palestinians died in custody. Two were certainly killed through torture, one apparently hanged himself, another was shot and killed.

${ }^{9}$ Facilities are overcrowded and dilapidated. Food and clothing is inadequate. Overall conditions were very poor.

${ }^{10}$ PA security forces abused and sometimes tortured detainees. This took place after arrest and during interrogation. Four Palestinians died in custody, two of torture.

${ }^{11}$ Because of early mariages girls often do not finish the mandatory level of schooling.

${ }^{12}$ Underage labour is used in the agricultural sector and in some West Bank and Gaza factories.

${ }^{13}$ Seven Palestinians died in custody of the PA, two of them as a result of torture. The other deaths could also be of torture as the PA reportedly treis to cover up incidents claiming that several deaths were the result of heart attacks or suicides. One palestinian woman was killed by undercover police when she failed to stop her vehicle, the officers responsible were convicted of death through negligence. Two land dealers were killed during the year. The PA announced the death penalty for people who gave "one inch" to Israel, but deny any involvement in the killings.

${ }_{15}^{14}$ Facilities are overcrowded and dilapidated. Food and clothing is inadequate. Overall conditions were very poor.

${ }_{15}^{15}$ PA security forces abused and sometimes tortured detainees. This took place after arrest and during interrogation.

${ }^{16}$ Because of early mariages girls often do not finish the mandatory level of schooling.

${ }^{17}$ A significant number of Palestinian children under the age of 16 and many under the age of 12 are engaged in some work activities. Most of this employment is believed to involve work on family farms, in family shops, or as urban street hawkers. Some mployment also occurs in small manufacturing enterprises. The law does not specifically prohibit forced or compulsory labor by children. The PA's capacity to enforce existing laws is limited.

${ }^{18}$ The PA security forces were responsible for several extrjudicial executions. Two palestinians died in custody. At least one died of torture. The other alledgedly committed suicide. Two Palestinians were killed by firing squad after being convicted by the Special Security Court. There are grave concerns that the defendants were not accorded due process. Two Palestinians accused of selling land to Jews were killed in suspicious circumstances.

${ }^{19}$ Facilities are overcrowded and dilapidated. Food and clothing is inadequate. Overall conditions were very poor. Conditions did improve.

${ }^{20}$ Though the report continues its use of the "standard" sentence, "PA security forces abused, and sometimes tortured, Palestinian detainees", it continues by saying, "International human rights groups have documented widespread arbitrary and abusive conduct by the PA. Human rights groups say that Palestinian prisoners frequently are tortured."

${ }^{21}$ Because of early mariages girls often do not finish the mandatory level of schooling.

${ }^{22}$ A significant number of Palestinian children under the age of 16 and many under the age of 12 are engaged in some work activities. Most of this employment is believed to involve work on family farms, in family shops, or as urban street hawkers. Some mployment also occurs in small manufacturing enterprises. The law does not specifically prohibit forced or compulsory labor by children. The PA's capacity to enforce existing laws is limited.

${ }^{23}$ Three Palestinians were killed in confrontations with security forces. The PA security forces were responsible for several extrjudicial executions. Two palestinians died in custody. One died after being shot while being interrogated. The other died allegedly of a heart attack, however family of the victim and a human rights organization said the victim was tortured. One Palestinian was killed by firing squad after being convicted by the Special Security Court. There are grave concerns that the defendant was not accorded due process.

${ }^{24}$ Facilities are overcrowded and dilapidated. Food and clothing is inadequate. Overall conditions were very poor.

${ }^{25}$ International human rights groups report torture is widespread and no longer confined to security detainees. The strong reliance on confessions (because the PA does not have enough equipment to collect evidence) hightens the possibility of torture.

${ }^{26}$ Because of early mariages girls often do not finish the mandatory level of schooling. Israeli permit policies affect Palestinian schools as they have not always been built with the right permits.

${ }^{27}$ A significant number of Palestinian children under the age of 16 and many under the age of 12 are engaged in some work activities. Most of this employment is believed to involve work on family farms, in family shops, or as urban street hawkers. Some mployment also occurs in small manufacturing enterprises. The law does not specifically prohibit forced or compulsory labor by children. The PA's capacity to enforce existing laws is limited. 
${ }^{28}$ Palestinian security forces killed several Israeli security forces. It is unclear whether PA officials authorized shootings against security forces and civilians. One Palestinian died in custody, because of torture.

${ }^{29}$ Facilities are overcrowded and dilapidated. Food and clothing is inadequate. Overall conditions were very poor.

${ }^{30}$ International human rights groups report torture is widespread and no longer confined to security detainees. The strong reliance on confessions (because the PA does not have enough equipment to collect evidence) hightens the possibility of torture.

${ }^{31}$ Because of early mariages girls often do not finish the mandatory level of schooling. Cultural restrictions sometimes prohibit women from attending colleges and universities. Closures affected student's ability to attend school. In areas under curfew all classes were cancelled. Furthermore, teachers were unable to reach their schools in different villages and towns.

${ }^{32}$ A significant number of Palestinian children under the age of 16 and many under the age of 12 are engaged in some work activities. Most of this employment is believed to involve work on family farms, in family shops, or as urban street hawkers. Some mployment also occurs in small manufacturing enterprises. The law does not specifically prohibit forced or compulsory labor by children. The PA's capacity to enforce existing laws is limited.

${ }^{33}$ Eleven Palestinians were killed in clashes with PA security forces. Members of the security forces and Arafat's Fatah faction participated in violent attacks against Israeli settlers, civilians and soldiers. However it is not clear to what extend these attacks have been authorized by PA and PLO officials. 5 Palestinians died in custody. Two of which alledgedly died from attempted suicide.

${ }^{34}$ Facilities are overcrowded and dilapidated. Food and clothing is inadequate. Overall conditions were very poor.

${ }^{35}$ PA security forces regularly torture detainees.

${ }^{36}$ Because of early mariages girls often do not finish the mandatory level of schooling. Cultural restrictions sometimes prohibit women from attending colleges and universities. In rural areas boys often leave school early to work to support their families. Closures affected student's ability to attend school. In areas under curfew all classes were cancelled. Furthermore, teachers were unable to reach their schools in different villages and towns. Test scores had dropped significantly in West Bank and Gaza schools.

${ }^{37}$ A significant number of Palestinian children under the age of 16 and many under the age of 12 are engaged in some work activities. Most of this employment is believed to involve work on family farms, in family shops, or as urban street hawkers. Some mployment also occurs in small manufacturing enterprises. The law does not specifically prohibit forced or compulsory labor by children. The PA's capacity to enforce existing laws is limited.

${ }^{38}$ Due to the closures there was a shortage of water and food.

${ }^{39}$ One Palestinian killed as a result of excessive force. Seven Palestinians killed in custody. Six of the victims were arrested on charges of collaboration with Israel, and vigilantes subsequently killed them. The PA security services either failed to protect the prisoners from attack or actively turned them over to their killers. One prisoner may have been tortured and killed.

${ }^{40}$ Facilities were old, dilapidated and neglected. Most prison facilities and detention centers were destroyed during the current conflict, and prisoners were kept informally in houses or other buildings.

${ }^{41}$ Torture and abuse were widespread. Article 13 of the PA Basic Law prohibits torture for the first time.

${ }^{42}$ Because of early mariages some girls in rural areas did not finish the mandatory level of schooling. Cultural restrictions sometimes prohibit women from attending colleges and universities. In rural areas and refugee camps boys often leave school early to work to support their families. Closures affected student's ability to attend school. In areas under curfew all classes were cancelled. Furthermore, teachers were unable to reach their schools in different villages and towns. Test scores had dropped significantly in West Bank and Gaza schools. For the first time in years

${ }^{43}$ Curfews caused food shortages and shortage of water. 


\section{A. LEGEND OF HUMAN RIGHTS VIOLATIONS:}

\section{CIVIL AND POLITICAL RIGHTS}

$\begin{array}{lll}\mathrm{e} & = & \text { Some extrajudicial executions } \\ \mathrm{E} & = & \text { Many extrajudicial executions } \\ \mathrm{p} & = & \text { Poor prison conditions } \\ \mathrm{P} & = & \text { Very poor prison conditions } \\ \mathrm{t} & = & \text { Some cases of torture } \\ \mathrm{T} & = & \text { Many cases of } / \text { systematic torture }\end{array}$

Note: Deaths as a result of torture will be noted under "torture", however these are also considered "extrajudicial killings".

\section{RIGHTS OF THE CHILD}

$\mathrm{AE}=\quad$ No or insufficient access to education (this may also include discrimination in schools/the education system of children of a certain origin)

$\mathrm{CA}=$ Child abuse (excluding abuse in prisons)

$\mathrm{CL}=$ Child labour

$\mathrm{CP}=$ Child prostitution

$\mathrm{CS}=$ Child soldiers

$\mathrm{FL}=$ Forced child labour

$\mathrm{PC}=$ Poor/very poor prison conditions for children (including abuse in prisons)

$\mathrm{S}=\quad$ Presence of great number of street children

$\mathrm{TL}=$ Trade in children for forced labour

$\mathrm{TP}=\quad$ Trade in children for prostitution

\section{RIGHT TO HOUSING}

$\mathrm{D}=$ Destruction of houses/property

$\mathrm{DH}=$ Discrimination in housing

$\mathrm{FE}=$ Forced eviction

$\mathrm{R}=\quad$ No right to return to house and property

\section{RIGHT TO FOOD}

IF $=\quad$ No or insufficient access to food and/or drinkable water

(If any of the findings is between brackets there is a reasonable suspicion) 


\section{B. EXPLANATION OF POLITICAL TERROR SCALE:}

\section{Political Terrorscale:}

Raw information comes from the United States Department of State(s) and Amnesty International. Distances between level are not equal, but a country on level one is doing better than a country on level two.

1. Countries live under a secure rule of law, people are not imprisoned for their views, and torture is rare or exceptional. Political murders are extraordinarily rare.

2. There is a limited amount of imprisonment for non-violent political activity. However, few persons are affected, torture and beatings are exceptional Political murder is rare.

3. There is extensive political imprisonment, or a recent history of such imprisonment. Executions or political murders and brutality may be common. Unlimited detention, with or without trial, for political views is accepted.

4. The practices of level 3 are expanded to larger numbers. Murders, disappearances, and torture are a common part of life. In spite of its generality, on this level violence affects primarily those who interest themselves in politics or ideas.

5. The violence of level 4 has been extended to the whole population. The leaders of these societies place no limits on the means or thoroughness with which they pursue personal or ideological goals.

1989 - 1996: Numbers from Purdue University. Purdue University political terrorscale is used. First number indicates the political terrorscale according to Amnesty International, the second number indicates the political terrorscale according to the U.S. State Department.

1997 - 2002: Numbers from the PIOOM World Conflict and Human Rights Maps (there are four such maps: 1996, 1998, 2000, 2001/2002). PIOOM numbers are based mainly on the annual reports of the U.S. State Department. PIOOM uses the five-point Purdue University political terrorscale.

\section{Maps/political terrorscale:}

1996: $\quad$ situation in 1995

1998: $\quad$ situation in 1997.

2000: situation in 1998 according to U.S. State Department.

2001 - 2002: situation in 2000 according to U.S. State Department. 


\section{EXPLANATION OF CONFLICTS LEVEL:}

\section{Conflict Level:}

- MC1: Violent political conflict: armed conflict that causes less than 100 deaths (not necessarily battle related) during a period of one year. Conflict parties gradually shift from non violent to violent strategies. Confrontations that occur may involve small scale violence. Terorist movements with an action oriented leadership exist. The legitisamacy of the government is clearly questioned.

- MC2: Low-intensity conflict: armed conflict that caused $100-1000$ deaths (non necessarily battle related) during a period of one year. In this phase there is open hostility and there are armed clashes between conflicting parties, depresseion is used to set due or deter insurrection. There may be a gradual shift from guerreilla warefare to conventional warefare.

- MC3: High-intensity conflict: an armed conflict with inceased levels of violence and depression causing the threshold of 1000 deaths (not necessarily battle related) during a period of one year. Open hostilities are characterized by massive destruction and a higher level of displacement. The category includes mass killing of unarmed civilians.

Maps:

1996: deaths occurred in 1996.

1998: deaths occurred between mid-1997 and mid-1998.

2000: deaths in conflict level 5 occurred between mid-1998 and mid2000 deaths in conflict level 3 and 4 occurred between mid 1999 and mid 2000.

2001 - 2002: deaths occurred between mid-2000 to mid-2001. 


\section{EXPLANATION OF CIVIL AND POLITICAL RIGHTS FROM FREEDOM HOUSE:}

The numbers indicate respectively:

- The level of political rights

- The level of civil liberties

- The status of the country

The levels range from 1 to 7 . The status is either Free (average of the first two numbers is between 1 and 2,5), Partly Free (average of the first two numbers is between 3 and 5,5), or Not Free (average is between 5,5 and 7). Freedom House does not see the averages a $\mathrm{s}$ absolute. This means a country that scores 3 can still be marked as Free. A considerable problem is posed by countries with averages of 5,5. Some countries will be marked as Partly Free, others as Not Free.

\section{Political Rights}

Countries and territories which receive a rating of 1 for political rights come closest to the ideals suggested by the checklist questions, beginning with free and fair elections. Those who are elected rule, there are competitive parties or other political groupings, and the opposition plays an important role and has actual power. Citizens enjoy selfdetermination or an extremely high degree of autonomy (in the case of territories), and minority groups have reasonable self-government or can participate in the government through informal consensus. With the exception of such entities as tiny island states, these countries and territories have decentralized political power and free sub national elections.

Countries and territories rated 2 in political rights are less free than those rated 1. Such factors as gross political corruption, violence, political discrimination against minorities, and foreign or military influence on politics may be present and weaken the quality of democracy.

The same conditions which undermine freedom in countries and territories with a rating of 2 may also weaken political rights in those with a rating of 3, 4, or 5. Other damaging elements can include civil war, heavy military involvement in politics, lingering royal power, unfair elections, and one-party dominance. However, states and territories in these categories may still enjoy some elements of political rights, including the freedom to organize quasi-political groups, reasonably free referenda, or other significant means of popular influence on government.

Countries and territories with political rights rated 6 have systems ruled by military juntas, one-party dictatorships, religious hierarchies, or autocrats. These regimes may allow only a minimal manifestation of political rights, such as competitive local elections or some degree of representation or autonomy for minorities. Some countries and territories rated 6 are in the early or aborted stages of democratic transition. A few states are traditional monarchies that mitigate their relative lack of political rights through the use of consultation with their subjects, toleration of political discussion, and acceptance of public petitions.

For countries and territories with a rating of 7, political rights are absent or virtually nonexistent due to the extremely oppressive nature of the regime or severe oppression 
in combination with civil war. States and territories in this group may also be marked by extreme violence or warlord rule which dominates political power in the absence of an authoritative, functioning central government.

\section{Civil Liberties}

Countries and territories which receive a rating of 1 come closest to the ideals expressed in the civil liberties checklist, including freedom of expression, assembly, association, and religion. They are distinguished by an established and generally equitable system of rule of law and are comparatively free of extreme government indifference and corruption. Countries and territories with this rating enjoy free economic activity and tend to strive for equality of opportunity.

States and territories with a rating of 2 have deficiencies in three or four aspects of civil liberties, but are still relatively free.

Countries and territories which have received a rating of 3, 4, or 5 range from those that are in at least partial compliance with virtually all checklist standards to those with a combination of high or medium scores for some questions and low or very low scores on other questions. The level of oppression increases at each successive rating level, particularly in the areas of censorship, political terror, and the prevention of free association. There are also many cases in which groups opposed to the state engage in political terror that undermines other freedoms. Therefore, a poor rating for a country is not necessarily a comment on the intentions of the government, but may reflect real restrictions on liberty caused by nongovernmental terror.

Countries and territories rated 6 are characterized by a few partial rights, such as some religious and social freedoms, some highly restricted private business activity, and relatively free private discussion. In general, people in these states and territories experience severely restricted expression and association, and there are almost always political prisoners and other manifestations of political terror.

States and territories with a rating of 7 have virtually no freedom. An overwhelming and justified fear of repression characterizes these societies. 